\title{
Targeting phosphodiesterase type 4 for improving cognitive fronto-striatal functioning
}

Citation for published version (APA):

Heckman, P. R. A. (2017). Targeting phosphodiesterase type 4 for improving cognitive fronto-striatal functioning: a translational approach. [Doctoral Thesis, Maastricht University]. Maastricht University. https://doi.org/10.26481/dis.20170704ph

Document status and date:

Published: 01/01/2017

DOI:

10.26481/dis.20170704ph

Document Version:

Publisher's PDF, also known as Version of record

\section{Please check the document version of this publication:}

- A submitted manuscript is the version of the article upon submission and before peer-review. There can be important differences between the submitted version and the official published version of record.

People interested in the research are advised to contact the author for the final version of the publication, or visit the DOI to the publisher's website.

- The final author version and the galley proof are versions of the publication after peer review.

- The final published version features the final layout of the paper including the volume, issue and page numbers.

Link to publication

\footnotetext{
General rights rights.

- You may freely distribute the URL identifying the publication in the public portal. please follow below link for the End User Agreement:

www.umlib.nl/taverne-license

Take down policy

If you believe that this document breaches copyright please contact us at:

repository@maastrichtuniversity.nl

providing details and we will investigate your claim.
}

Copyright and moral rights for the publications made accessible in the public portal are retained by the authors and/or other copyright owners and it is a condition of accessing publications that users recognise and abide by the legal requirements associated with these

- Users may download and print one copy of any publication from the public portal for the purpose of private study or research.

- You may not further distribute the material or use it for any profit-making activity or commercial gain

If the publication is distributed under the terms of Article $25 \mathrm{fa}$ of the Dutch Copyright Act, indicated by the "Taverne" license above, 
Targeting phosphodiesterase type 4 for improving cognitive fronto-striatal functioning

a translational approach

Pim Raymond Andreas Heckman 
Copyright (C Pim Heckman, Kerkrade, 2017

ISBN: 978-94-92679-06-2

Targeting phosphodiesterase type 4 for improving cognitive fronto-striatal functioning: a translational approach

All rights reserved. No part of this thesis may be reproduced, stored in a retrieval database or published in any form or by any means, electronic, mechanical or photocopying, recording or otherwise, without the prior written permission of the author or, when appropriate, from the copyright-owning journals of previously published chapters.

Cover design by Pim Heckman

Typesetting, layout and printing by Printservice Ede 


\title{
Targeting phosphodiesterase type 4 for improving
}

\section{cognitive fronto-striatal functioning:}

\section{a translational approach}

\begin{abstract}
PROEFSCHRIFT
Ter verkrijging van de graad van doctor aan de Universiteit Maastricht, op gezag van de Rector Magnificus, Prof. dr. R.M. Letschert, volgens het besluit van het College van Decanen

in het openbaar te verdedigen op dinsdag 4 juli 2017 om 12.00 uur
\end{abstract}

door

Pim Raymond Andreas Heckman

geboren op 24 november 1986

te Heerlen 


\section{Promotor}

Prof. dr. J.G Ramaekers

\section{Copromotores}

Dr. J.H.H.J. Prickaerts

Dr. A. Blokland

\section{Beoordelingscommissie}

Prof. dr. W.J. Riedel (voorzitter)

Prof. dr. R. D’Hooge (Katholieke Universiteit Leuven)

Prof. dr. H.H.H.W. Schmidt

Dr. T. Vanmierlo (Universiteit Hasselt)

Dr. A.R. West (Rosalind Franklin University of Medicine and Science, Chicago) 


\section{Contents}

\section{Chapter 1}

General Introduction (short outline + aims)

\section{Chapter 2}

PDE and cognitive processing: beyond the memory domain

\section{Chapter 3}

Phosphodiesterase inhibition and regulation of dopaminergic frontal and striatal functioning: clinical implications

\section{Chapter 4}

Acute administration of roflumilast enhances sensory gating in healthy young humans in a randomized trial

\section{Chapter 5}

Effects of the phosphodiesterase type 4 inhibitor roflumilast on the tri-phasic response of the substantia nigra pars reticulata after infralimbic cortex stimulation

\section{Chapter 6}

The mediating role of phosphodiesterase type 4 in the dopaminergic modulation of motor impulsivity

\section{Chapter 7}

General Discussion and Conclusion

\section{Chapter 8}

Summary 


\section{List of abbreviations}

\begin{tabular}{|c|c|c|}
\hline 6-OHDA & $=$ & 6-hydroxydopamine \\
\hline AC & $=$ & adenylyl cyclase \\
\hline ACC & $=$ & anterior cingulate cortex \\
\hline ADHD & $=$ & attention deficit hyperactivity disorder \\
\hline ACC & $=$ & anterior cingulate cortex \\
\hline$A D$ & $=$ & Alzheimer's disease \\
\hline AEP & $=$ & auditory evoked potentials \\
\hline AKAP & $=$ & A-kinase anchoring protein \\
\hline ALS & $=$ & amyotrophic lateral sclerosis \\
\hline AMPA & $=$ & $\alpha$-amino-3-hydroxy-5-methyl-4-isoxazolepropionic acid \\
\hline ASR & $=$ & acoustic startle response \\
\hline ATP & $=$ & adenosine triphosphate \\
\hline BBB & $=$ & blood-brain barrier \\
\hline BDNF & $=$ & brain-derived neurotrophic factor \\
\hline BID & $=$ & bis in die (twice a day) \\
\hline CA & $=$ & cornu ammonis (of the hippocampal formation) \\
\hline CAAT & $=$ & conditioned avoidance attention task \\
\hline $\mathrm{Ca}^{2+}$ & $=$ & calcium \\
\hline CaM & $=$ & calmodulin \\
\hline CaMk & $=$ & $\mathrm{Ca}^{2+} /$ calmodulin-dependent protein kinase \\
\hline CAMP & $=$ & cyclic adenosine monophosphate \\
\hline cGMP & $=$ & cyclic guanosine monophosphate \\
\hline CNGC & $=$ & cyclic nucleotide-gated channels \\
\hline CNS & $=$ & central nervous system \\
\hline COPD & $=$ & chronic obstructive pulmonary disease \\
\hline CREB & $=$ & CAMP response element binding protein \\
\hline CSRTT & $=$ & choice serial reaction time task \\
\hline CS & $=$ & conditioned stimulus \\
\hline D1 & $=$ & dopamine type 1 receptor \\
\hline D2 & $=$ & dopamine type 2 receptor \\
\hline DA & $=$ & dopamine \\
\hline DARPP-32 & $=$ & dopamine- and cAMP-regulated phosphoprotein MR $32 \mathrm{kDa}$ \\
\hline
\end{tabular}




\begin{tabular}{|c|c|c|}
\hline DISC-1 & $=$ & disrupted in schizophrenia 1 \\
\hline dIPFC & $=$ & dorsolateral prefrontal cortex \\
\hline DOPAC & $=$ & 3,4-dihydroxyphenylacetic acid \\
\hline ECoG & $=$ & electrocorticogram \\
\hline ED & $=$ & erectile dysfunction \\
\hline EEG & $=$ & electroencephalography \\
\hline EPAC & $=$ & exchange factor directly activated by cAMP \\
\hline ERK & $=$ & extracellular receptor kinase \\
\hline ERP & $=$ & event-related potential \\
\hline FDA & $=$ & US food and drug administration \\
\hline GABA & $=$ & $\gamma$-aminobutyric acid \\
\hline GC & $=$ & guanylyl cyclase \\
\hline $\mathrm{GP}_{\mathrm{e}}$ & $=$ & globus pallidus pars externa \\
\hline$G P_{i}$ & $=$ & globus pallidus pars interna \\
\hline HDGEC & $=$ & Huntington's disease gene expansion carriers \\
\hline IBMX & $=$ & isobutylmethylxanthine \\
\hline IKK & $=$ & IkB kinase \\
\hline IL & $=$ & infralimbic cortex \\
\hline ISI & $=$ & inter stimulus interval \\
\hline ITI & $=$ & inter trial interval \\
\hline KO & $=$ & knockout \\
\hline $\mathrm{LI}$ & $=$ & latent inhibition \\
\hline LID & $=$ & levodopa-induced dyskinesia \\
\hline LTD & $=$ & long-term depression \\
\hline LTP & $=$ & long-term potentiation \\
\hline $\mathrm{MCl}$ & $=$ & mild cognitive impairment \\
\hline MMSE & $=$ & mini-mental state examination \\
\hline mPFC & $=$ & medial prefrontal cortex \\
\hline mRNA & $=$ & messenger ribonucleic acid \\
\hline MSN & $=$ & medium spiny neuron \\
\hline NAC & $=$ & nucleus accumbens \\
\hline NE & $=$ & norepinephrine \\
\hline NMDA & $=$ & N-methyl-D-aspartate \\
\hline NO & $=$ & nitric oxide \\
\hline NOS & $=$ & nitric oxide synthase \\
\hline
\end{tabular}




\begin{tabular}{|c|c|c|}
\hline OCD & $=$ & obsessive-compulsive disorder \\
\hline ORDT & $=$ & object retrieval detour task \\
\hline PANNS & $=$ & positive and negative syndrome scale \\
\hline PCP & $=$ & phencyclidine \\
\hline PCREB & $=$ & phosphorylated CREB \\
\hline PD & $=$ & Parkinson's disease \\
\hline PDE & $=$ & phosphodiesterase \\
\hline PDE-I & $=$ & phosphodiesterase inhibitor \\
\hline PET & $=$ & positron emission tomography \\
\hline PKA & $=$ & protein kinase $A$ \\
\hline PKG & $=$ & protein kinase G \\
\hline $\mathrm{PnC}$ & $=$ & pontine reticular nucleus \\
\hline PP-1 & $=$ & protein phosphatase-1 \\
\hline PPI & $=$ & prepulse inhibition \\
\hline PPTg & $=$ & pedunculopontine tegmental nucleus \\
\hline PSTH & $=$ & peristimulus-time histogram \\
\hline RACK1 & $=$ & receptor for activated $\mathrm{C}$ kinase 1 \\
\hline $\mathrm{rCBF}$ & $=$ & regional cerebral blood flow \\
\hline $\mathrm{SN}_{\mathrm{c}}$ & $=$ & substantia nigra pars compacta \\
\hline $\mathrm{SN}_{\mathrm{r}}$ & $=$ & substantia nigra pars reticulata \\
\hline STN & $=$ & subthalamic nucleus \\
\hline TH & $=$ & tyrosine hydroxylase \\
\hline TrkB & $=$ & tropomyosin-related kinase B \\
\hline US & $=$ & United States \\
\hline US & $=$ & unconditioned stimulus \\
\hline VTA & $=$ & ventral tegmental area \\
\hline WAIS & $=$ & Wechsler adult intelligence scale \\
\hline
\end{tabular}


Chapter 1

General introduction 
Acting means doing something for a particular purpose or to solve a problem (Cambridge dictionary, 2017). It starts with early information processing steps leading all the way up to the execution of a response. Acting involves motor, cognitive and limbic components. Acting includes bottom-up processes like sensation, perception, evaluation of different possible actions and context analysis. Additionally, top-down processes including inhibitory control, motivation, emotional state and experience congregate and shape the bottom-up processing of information resulting in action selection and execution. Sometimes, we act before adequately sampling and evaluating available information (impulsivity). However, our actions have an optimal effect when they are well prepared and when the context is evaluated properly. In order to achieve this goal, evolution has shaped the brain constructing a complex network in which all the information is brought together, known as the fronto-striatal circuits.

\section{The fronto-striatal circuits}

The fronto-striatal circuits are parallel organized circuits that run from the frontal cortex, through the basal ganglia, to the thalamus from where they project back to the frontal cortex, closing the circuits (Alexander et al., 1986; Alexander et al., 1990). Therefore, fronto-striatal circuits are also known as cortico-striatal-thalamic loops. The fronto-striatal circuits consist of motor, associative/cognitive and limbic circuits (Alexander et al., 1986; Alexander et al., 1990). Each circuit originates in a different part of the frontal cortex. Similarly, different parts of the basal ganglia structures and thalamus participate in these parallel segregated circuits (Yeterian and Pandya, 1991; Slattery et al., 2001). The different circuits are oriented dorsal to ventral and, even though they are called fronto-striatal circuits, the ventral limbic circuits originate not only from the frontal cortex (anterior cingulate cortex (ACC)) but also from the hippocampus and amygdala (Temel et al., 2005). At least five circuits can be distinguished: the oculo-motor circuit (eye movement), motor circuit (motor functioning), dorsolateral prefrontal circuit (cognitive functioning), the orbitofrontal circuit (cognitive functioning) and anterior cingulate circuit (limbic functioning).

The fronto-striatal circuits start with glutamatergic cortical efferents to the striatum (caudate nucleus, putamen and nucleus accumbens (NAC)). Within the basal ganglia all projections are $\gamma$-aminobutyric acid (GABA)-ergic except for output from the subthalamic nucleus (STN) which is glutamatergic. In the basal ganglia each fronto-striatal circuit splits into a direct and an indirect pathway. Cortical glutamatergic activation of a striatal direct pathway stimulates the release of GABA, having an inhibitory effect in the globus pallidus pars interna (GPi) and substantia nigra pars reticulata (SNr). As the GPi and SNr inhibit the thalamus, which in turn stimulates the cortex, activation of the direct pathway causes disinhibition of the thalamus leading to increased excitatory output of the neural 
network, and thereby activation of behavior (either motor, cognitive or limbic). The indirect pathway has the opposite effect. Activation of the indirect pathway induces GABA release in the globus pallidus pars externa (GPe) which normally inhibits the release of GABA to the STN. The STN is thus disinhibited and increases stimulation of the GPi/SNr, which in turn inhibits the thalamic stimulation back to the cortex and results in inhibition of behavior. Additionally, the hyperdirect pathway consists of cortical glutamatergic projections to the STN, thereby completely circumventing the striatum. This STN activation increases stimulation of the GPi/SNr, resulting in inhibition of the thalamic stimulation to the cortex. Without cortical stimulation the GPi and the SNr function like autonomous pacemakers, tonically inhibiting the thalamus, thereby preventing cortical stimulation, i.e. behavioral output (for a more extensive discussion (see Haber and Rauch, 2010; Gerfen and Surmeier, 2011; Surmeier et al., 2011; Calabresi et al., 2014)).

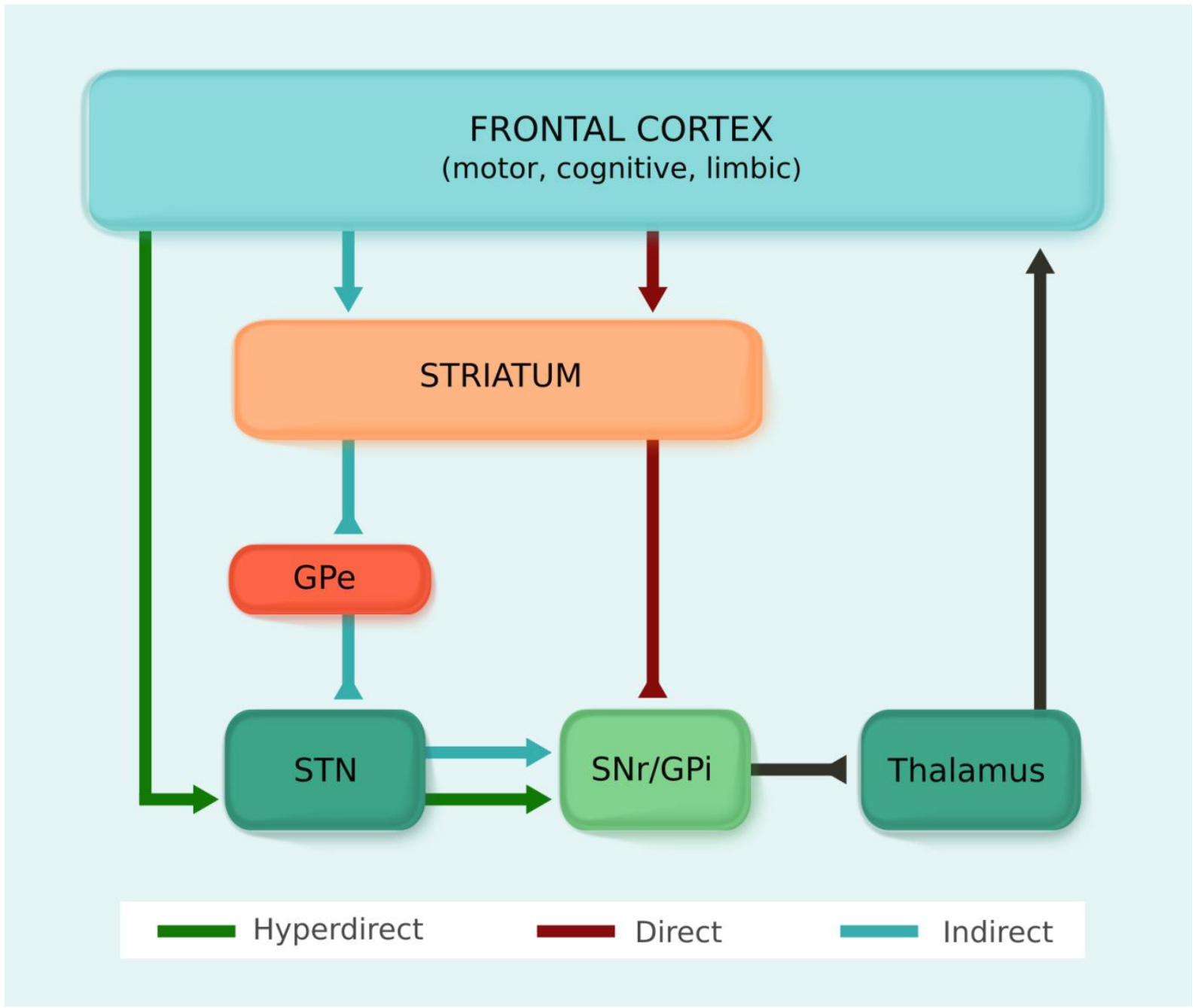

Figure 1. Hyperdirect, direct and indirect pathways of the fronto-striatal circuit. Hyperdirect pathway: frontal cortex-STN-SNr/GPi-thalamus. Direct pathway: striatum-SNr/GPi-thalamus. Indirect pathway: striatum-GPeSTN-SNr/GPi-thalamus. STN=subthalamic nucleus, SNr=substantia nigra pars reticulata, GPi=globus pallidus pars 
interna, GPe=globus pallidus pars externa. Sharp arrow heads represent excitatory connections; blunted arrow heads represent inhibitory connections.

\section{Dopaminergic modulation}

At the level of the basal ganglia the fronto-striatal system is modulated by various GABAergic and cholinergic interneurons (Calabresi et al., 2014). Additionally, every circuit is modulated by dopamine (Surmeier et al., 2007; Surmeier et al., 2011). Dopaminergic cells from substantia nigra pars compacta (SNc) and ventral tegmental area (VTA) project to almost every structure within the circuits (e.g. nigrostriatal, mesolimbic, mesocortical and thalamic dopamine projections). As a result, dopaminergic receptors are strongly expressed throughout the fronto-striatal circuits (Gerfen and Surmeier, 2011; Nishi et al., 2011; Kuroiwa et al., 2012). Unsurprisingly, dopaminergic medication has proven effective as treatment for several disorders related to dysfunctional fronto-striatal circuits (e.g. ADHD, schizophrenia, Parkinson's disease). Dopamine released from SNc and/or VTA binds to both dopamine type1 (D1) receptors and dopamine type2 (D2) receptors on medium spiny neurons (MSNs) in the striatum (Gerfen and Surmeier, 2011). D1 receptors are mainly found on MSNs of the direct pathway and D2 receptors are mainly found on MSNs of the indirect pathway where they establish antagonistic interactions with adenosine $A_{2 A}$ receptors (Gerfen et al., 1990; Ferre et al., 2011). D1 receptors activate the $\mathrm{G}_{\mathrm{s} / \mathrm{olf}}$ family of $\mathrm{G}$ proteins to stimulate cyclic adenosine monophosphate (cAMP) production and thereby the direct pathway in the striatum (Sibley et al., 1993; Beaulieu and Gainetdinov, 2011). In contrast, the $D 2$ receptors couple to the $G_{i / o}$ family of $G$ proteins and thus induce inhibition of cAMP production, thereby inhibiting the indirect pathway which eventually leads to disinhibition of the frontal cortex. Actions of the dopamine receptors in both pathways can be viewed as synergistically or complementary.

Several neuropsychiatric disorders, including neurodegenerative disorders like Parkinson's disease and Huntington's disease, psychiatric illnesses such as schizophrenia, bipolar disorder and obsessivecompulsive disorder, and pervasive developmental disorders like attention deficit hyperactivity disorder (ADHD) and autism spectrum disorder, all share the fronto-striatal circuits as their neurobiological basis (Alexander et al., 1986; Haber and Rauch, 2010; Gunaydin and Kreitzer, 2015). Dysfunction of these circuits produces a wide range of motor, cognitive and affective symptoms observed in these neuropsychiatric disorders (Chudasama and Robbins, 2006).

The need to develop strategies (e.g. pharmacotherapy, gene-therapy, immunotherapy) that treat neuropsychiatric disorders is high since the accompanying symptoms and discomfort have a large impact on the quality of life of the patients and constitute a major burden to society. As a result, 
several strategies have been described targeting a wide range of domains. Research has focused on both environmental and genetic factors that cause neuronal dysfunction and death, or on enhancement of the ability of neurons to adapt (e.g. Mattson et al., 2002). Despite the large effort that has been put in these strategies, currently available treatment shows often low efficacy and/or high rates of adverse events. Therefore, the need for strategies that counteract the detrimental processes involved in the decline of motor, cognitive and affective functioning (efficacy) with better side-effect profiles (adverse events) remains high.

\section{Phosphodiesterases}

Recently, phosphodiesterases (PDEs) are receiving increased attention as possible pharmacotherapeutic target for treatment of disorders characterized by motor, cognitive and affective symptoms related to fronto-striatal circuit dysfunction. There are eleven subfamilies of PDE comprising about 21 different genes, each containing several splice variants and isoforms making up more than a hundred specific human PDEs (Bender and Beavo, 2006) (see Table 1) and each having a specific localization in the human body (Rentero et al., 2003; Wang et al., 2003; Esposito et al., 2009; Lakics et al., 2010). PDEs degrade the second messengers cAMP and/or cyclic guanosine monophosphate (cGMP). PDE1, PDE2, PDE3, PDE10 and PDE11 are dual-substrate PDEs. PDE4, PDE7 and PDE8 are cAMP-specific, whereas PDE5, PDE6 and PDE9 are cGMP-specific (Beavo, 1995). A PDE inhibitor is a pharmacological compound blocking one or more isoforms of PDEs, thus increasing second messengers and improving intra- and intercellular signaling (Bender and Beavo, 2006).

\section{Table 1}

Overview of different PDE families, properties, substrates and compounds

\begin{tabular}{clll}
\hline Type & \multicolumn{1}{c}{ Property } & Substrate & $\begin{array}{l}\text { Clinically evaluated } \\
\text { inhibitors }\end{array}$ \\
\hline PDE1 & $\begin{array}{l}\mathrm{Ca}^{2+} \text {-CaM- } \\
\text { stimulated }\end{array}$ & cAMP/cGMP & Vinpocetine, ITI-214 \\
PDE2 & $\begin{array}{l}\text { cGMP- } \\
\text { stimulated }\end{array}$ & cAMP/cGMP & - \\
PDE3 & cGMP-inhibited & cAMP/cGMP & Cilostazol \\
PDE4 & cAMP-specific & cAMP & Rolipram, ND1251, MK- \\
& & & 0952, MEM1414, HT- \\
& & & 0712, roflumilast, \\
& & & Denbufylline
\end{tabular}




\begin{tabular}{|c|c|c|c|}
\hline PDE5 & cGMP-specific & cGMP & $\begin{array}{l}\text { Sildenafil, udenafil, } \\
\text { vardenafil }\end{array}$ \\
\hline PDE6 & Photoreceptor & cGMP & - \\
\hline PDE7 & $\begin{array}{l}\text { cAMP high } \\
\text { affinity }\end{array}$ & CAMP & - \\
\hline PDE8 & $\begin{array}{l}\text { cAMP high } \\
\text { affinity }\end{array}$ & cAMP & - \\
\hline PDE9 & $\begin{array}{l}\text { cGMP high } \\
\text { affinity }\end{array}$ & cGMP & PF-04447943, BI 409306 \\
\hline PDE10 & cAMP-inhibited & cAMP/cGMP & $\begin{array}{l}\text { MP-10, TAK-063, } \\
\text { RO5545965, AMG 579, } \\
\text { OMS824 }\end{array}$ \\
\hline PDE11 & Dual substrate & cAMP/cGMP & - \\
\hline
\end{tabular}

With regard to cognition enhancement, initially, memory deficits related to Alzheimer's disease were the focus of PDE inhibitor research (e.g. Blokland et al., 2006; Heckman et al., 2015a; Wang et al., 2015). However, nowadays PDE inhibitors are also investigated as cognition enhancers in for example depression (e.g. Wong et al., 2006; Esposito et al., 2009; Zhang, 2009; Fujita et al., 2012; O'Donnell and Xu, 2012) and schizophrenia (Menniti et al., 2007; Siuciak, 2008; Zhang, 2010; Duinen et al., 2015; Heckman et al., 2015b).

With regard to the potential of PDE inhibitors as a treatment for motor dysfunctions, Parkinson's disease (Belmaker et al., 1978; Volicer et al., 1986; Nishino et al., 1993; Sancesario et al., 2004) and Huntington's disease (DeMarch et al., 2007; DeMarch et al., 2008; Puerta et al., 2010) are the main researched disorders. Additionally, cyclic nucleotide regulation by PDE inhibitors has been related to tardive dyskinesia induced by antipsychotic treatment, or levodopa-induced dyskinesias (Sasaki et al., 1995; Yamashita et al., 1997b; Yamashita et al., 1997a; Sharma et al., 2013; Wilson and Brandon, 2015).

Finally, PDE inhibitors have also been linked to affect and emotion in disorders like depression, schizophrenia (negative symptoms) and anxiety disorders (Brink et al., 2008; Hebb et al., 2008; Schmidt et al., 2008; Zinn et al., 2009; Reierson et al., 2011; Smith et al., 2013; Ding et al., 2014; Rutter et al., 2014; Plattner et al., 2015; Zhang et al., 2015). 


\section{Phosphodiesterases in the fronto-striatal circuits}

Within the fronto-striatal circuits, cAMP influences both presynaptic neurotransmitter release and postsynaptic intracellular pathways. The former might be mediated via a presynaptic calcium $\left(\mathrm{Ca}^{2+}\right)$ /calmodulin-dependent protein kinase (CaMK)/cAMP/CAMP-dependent protein kinase (PKA) cascade and elevation of CAMP has been found to result in the synthesis and/or release of several neurotransmitters including two main players in the fronto-striatal circuits: glutamate and dopamine (Schoffelmeer et al., 1985; Imanishi et al., 1997; Rodriguez-Moreno and Sihra, 2013). The influence on postsynaptic intracellular pathways occurs through activation of postsynaptic PKA by CAMP produced by AC stimulated by either glutamatergic-induced $\mathrm{Ca} 2+$ influx or dopamine receptorstimulated $G_{s}$. After PKA activation, two subsequent pathways play an important function in the fronto-striatal circuits: CAMP response element binding protein (CREB) pathway (Mayr and Montminy, 2001) and the Dopamine- and cAMP-Regulated PhosphoProtein MR 32 kDa (DARPP-32) pathway (Greengard, 2001; Svenningsson et al., 2004). In the first pathway, glutamate or dopamine activated PKA signaling subsequently phosphorylates CREB (pCREB). pCREB is an activated transcription factor, which initiates transcription of specific genes influencing neuroplasticity. The latter includes genes for neurotransmitter receptors such as ionotropic $\alpha$-amino-3-hydroxy-5-methyl4-isoxazolepropionic acid (AMPA) receptors or growth factors as brain-derived neurotrophic factor (BDNF) (Scott Bitner, 2012). The dopamine receptor/CAMP/PKA/DARPP-32 cascade constitutes the second pathway. DARPP-32 is phosphorylated at Thr34 in both striatal and frontal neurons converting into a potent inhibitor of protein phosphatase-1 (PP-1), whereas phosphorylation at Thr75 by Cdk5 converts DARPP-32 into an inhibitor of PKA. DARPP-32 has therefore the unique property of being a dual-function protein, acting either as an inhibitor of PP-1 or PKA, respectively stimulating or inhibiting neuroplasticity, respectively (Svenningsson et al., 2004). Of note, the DARPP-32 signaling cascade is also linked to the CREB pathway (Greengard et al., 1999).

In addition to the backbone formed by MSNs and their dopaminergic modulation, the importance of interneurons in physiological and pathological fronto-striatal functioning is becoming increasingly apparent. Several types of interneurons can be found in the striatum, like cholinergic and different GABAergic interneurons (Gerfen and Surmeier, 2011). In particular, nitric oxide synthase (NOS) containing GABAergic interneurons I would like to highlight. These nitric oxide (NO)-producing interneurons play an important role in fronto-striatal functioning (West and Tseng, 2011). NO diffuses into dendrites of MSNs which contain high levels of guanylate cyclase (GC), which, when activated, lead to the synthesis of cGMP. In the intact striatum, transient elevations in intracellular cGMP primarily act to increase neuronal excitability and to facilitate glutamatergic fronto-striatal transmission (West and Tseng, 2011; Threlfell and West, 2013). Although the main focus in the 
fronto-striatal system has been on CAMP signaling, several PDE inhibitors (also) target cGMP and may exert their effects largely dependent on cGMP signaling cascade (Padovan-Neto et al., 2015).

Since the focus of the dissertation is on fronto-striatal dopaminergic regulation, PDE1B, PDE2A, PDE4, PDE7B, PDE9A, and PDE10A in particular are of special interest (Lakics et al., 2010). PDE1B, PDE7B, and PDE10A are highest enriched in striatum and/or frontal cortex. PDE2A, PDE4 (A, B, D), and PDE9A are more widely distributed but are also expressed in striatum and/or frontal cortex. There are only very limited preclinical data on PDE2A, PDE7A, and PDE9A inhibition. To date, most research has been devoted to the potential of PDE1B, PDE4, and PDE10A for regulation of dopaminergic frontostriatal signaling, and therefore these subtypes will be predominantly discussed in the present thesis with an emphasis on PDE4.

In addition to their well-known activating effect on PKA and PKG, cyclic nucleotides bind to cyclic nucleotide-gated channels (CNGCS) and 'exchange factor directly activated by CAMP' 1 and 2 (EPAC1 and EPAC2) (Keravis and Lugnier, 2012). Because the activities of several of these effectors can be altered simultaneously in response to increases in cellular cAMP or cGMP, PDE inhibitors can activate several cellular signaling events that yield a series of finely-tuned 'read-outs' and that markedly affect the numerous cellular processes (Conti and Beavo, 2007; Francis et al., 2011). In the frontostriatal circuits, the main cellular processes are believed to be those related to neuroplasticity and neuroprotection through previously mentioned activation of CREB and DARPP-32 pathways. We consider both the latter to be the general mechanisms of action of PDE inhibition in the frontostriatal circuits. However, known effects of PDE inhibitors on neurodegeneration, neuroinflammation and cytokine-mediated responses may play additional roles, yet are outside the scope of the present thesis (Hebb and Robertson, 2008; Wilson and Brandon, 2015).

The integration of individual PDEs into specific groups of proteins involved in the regulation of protein degradation, so called signalosomes, within regionally-restricted, subcellular compartments of neurons of the fronto-striatal circuits, determines the functional roles of these individual PDEs and their respective isoforms (Jurevicius and Fischmeister, 1996; Zaccolo et al., 2000; Mongillo et al., 2006; Maurice, 2011; Stangherlin et al., 2011; Stangherlin and Zaccolo, 2012). In addition, different PDE isoforms can integrate multiple distinct cellular inputs and allow crosstalk between cyclic nucleotides and other signaling networks and systems (Dodge-Kafka et al., 2005; Mongillo et al., 2006; Houslay et al., 2007; Stangherlin et al., 2011; Wilson et al., 2011; Kritzer et al., 2012). Together, this is considered the main determinant of the target PDE isoform within a specific neuropsychiatric disorder related to the fronto-striatal circuits. 


\section{Targeting PDEs for inhibition}

Increased PDE activity is assumed to reduce CAMP signaling in pathways important for brain plasticity and neuroprotection and is therefore considered to be causal, while a decrease in PDE activity might be considered as compensatory (Bollen and Prickaerts, 2012; Gurney et al., 2015). Additionally, PDE expression is assumed to decrease with aging. Whether this is an age-related decrease or a compensatory mechanism is not known (Richter et al., 2013).

From a therapeutic perspective, the response of a biological system to an endogenous or exogenous molecule depends upon the dose. Therefore, it is crucial to perform what is termed 'dose-response curves' (often inverted-U shaped). In the current thesis, these dose-response curves explain optimal levels of performance by cAMP/PKA activity and bioavailability. Pharmacological agents thus aim to induce optimal levels of cAMP thereby enhancing performance (cognition enhancement). Aging and mental illness can increase or decrease levels of cAMP/PKA. This change in cyclic nucleotide activity and bioavailability can be compensated by pharmacological agents returning them to optimal levels. Regarding PDEs and their respective inhibitors, it appears most promising to target PDEs with increased expression. This way, cognition and plasticity deficits resulting from impaired cAMP/PKA signaling might be improved by inhibiting specific PDE isoforms. However, PDE inhibition might have negative effects on cognition and plasticity when PDEs are already downregulated and cAMP levels and PKA activity are high which results in shifting the dose-response curve to the left. In this scenario, elevating CAMP levels might go over a physiological level and disrupt signaling. Along this line, high doses of rolipram impaired prefrontal cognitive function in aged, but not young monkeys, likely due to overstimulation of the already disinhibited CAMP/PKA signaling pathway in the aged prefrontal cortex (Ramos et al., 2003; Arnsten et al., 2005). This argues to specifically target PDEs that are overexpressed. Consequently, the inhibition of, in particular, PDE4 could be a translational tool to modulate the intracellular cyclic nucleotide signaling cascades, thereby improving cognitive frontostriatal functioning

\section{Aim and outline of the thesis}

As outlined above, PDE4 might be a relevant target for the treatment of cognitive dysfunctions in disorders related to the fronto-striatal circuits. Therefore, the main aim of the current dissertation is to further investigate the function of PDE4 in cognitive fronto-striatal circuits. The focus is set on cognition, opposed to motor and limbic functions of the fronto-striatal circuits, and includes cognitive functions such as attention, sensory gating, sensorimotor gating and impulsivity. This 
requires a thorough review on the existing literature to understand the current status in this field. In the first chapter, it will be evaluated how PDE inhibition can lead to changes in the functions of the fronto-striatal circuit. This chapter provides thus an overview of the efficacy of PDE inhibitors, especially inhibitors of PDE4, as modulators of the fronto-striatal circuits (Chapter 2).

Chapter 3 provides an overview of the current status of the knowledge on the role of PDE1, PDE4 and PDE10 in the regulation of dopaminergic modulation of fronto-striatal circuits. Dopamine is one of the key neurotransmitters in the fronto-striatal-thalamic circuitry. Further, recent studies suggest that PDE inhibition may modulate dopamine release. In contrast to the previous chapter, this chapter discusses the relation between PDEs and dopamine in relation to the cognitive functions in more detail. In addition to a discussion on the neurobiological mechanisms of PDE inhibition, a clinical perspective for PDE inhibition will be provided.

The next chapter (Chapter 4) describes the effects of the PDE4 inhibitor roflumilast in the sensory gating paradigm tested in healthy humans. Sensory gating is a process involved in early information processing which prevents overstimulation of the brain. It is especially affected in patients suffering from schizophrenia, Alzheimer's disease and ADHD. Sensory gating is believed to be induced by inhibitory interneurons of the auditory cortex and the thalamic 'gate', frontal inhibitory output neurons or in the interneurons that locally release inhibitory neurotransmitter in any other brain area capable of eliciting sensory gating. The neurobiology of sensory gating can thus mainly be found in the fronto-striatal circuits. It is known that PDE4 is highly expressed in fronto-striatal areas related to sensory gating including the thalamus and frontal cortex (Lakics et al., 2010). Therefore, we investigated the effects of roflumilast on sensory gating in healthy human participants (Chapter 4).

In Chapter 5 we examine the functional output of the fronto-striatal circuit to the thalamus at an electrophysiological level. More specifically, the aim of this study was to better understand the role of PDE4 in the fronto-striatal pathways. This will be accomplished by studying the distinctive effects of PDE4 inhibition on the three basal ganglia pathways: the hyperdirect, direct and indirect pathway. The effects of roflumilast on the three pathways will be studied via the tri-phasic (excitationinhibition-excitation) response of the SNr after infralimbic cortex stimulation. The SNr is the output module of the basal ganglia and the location where all three pathways come together. The infralimbic cortex is stimulated because the cognitive fronto-striatal circuits in the rat originate within the medial prefrontal cortex. This study will reveal which pathway is sensitive to PDE4 inhibition and may contribute to a better understanding how PDE4 inhibition may affect functions in the cortico-striatal system (Chapter 5). 
In Chapter 6, the mediating role of PDE4 in the dopaminergic modulation of premature responding (motor impulsivity) will be investigated. Response inhibition, which includes action restraint, finds its neurobiological origin in fronto-striatal circuitry and can be modulated by dopamine. Intracellularly, the effect of dopamine is largely mediated through the cAMP/PKA signaling cascade. It has been suggested that areas in the prefrontal cortex are very sensitive to their neurochemical environment, including catecholamine levels (Arnsten, 2009). Both high and low catecholamine release in the prefrontal cortex impairs prefrontal cortex function. As a result, we are interested in the effects of PDE4 inhibition on premature responding in a hypo, normal and hyper dopaminergic state of the brain. As a hypo dopaminergic model we will induce a 6-OHDA lesion in the prefrontal cortex, more specifically the infralimbic cortex. This is a well-known animal model for the induction of ADHD symptoms including motor impulsivity related to action restraint (Freund et al., 2014; Lukkes et al., 2016). For the hyperdopaminergic state we also turn to a well-established model of impaired action restraint, namely the systemic administration of d-amphetamine, which has proven to robustly increase premature responding (Winstanley et al., 2006). Taken together, we investigate the effects of a PDE4 inhibitor on premature responding in a choice reaction time task in a hypo, normal and hyper dopaminergic state of the fronto-striatal circuitry.

To conclude, the main aim of the dissertation is to investigate the role of PDE4 in the fronto-striatal circuits with an emphasis on cognition. This was investigated in both a physiological (Chapter 4 and Chapter 5) as well as a pathophysiological (Chapter 6) condition of the fronto-striatal circuit. The main findings of the current dissertation are summarized and discussed in Chapter 7. 


\section{References}

Alexander GE, DeLong MR, Strick PL (1986) Parallel organization of functionally segregated circuits linking basal ganglia and cortex. Annu Rev Neurosci 9:357-381.

Alexander GE, Crutcher MD, DeLong MR (1990) Basal ganglia-thalamocortical circuits: parallel substrates for motor, oculomotor, "prefrontal" and "limbic" functions. Prog Brain Res 85:119146.

Arnsten AF (2009) Toward a new understanding of attention-deficit hyperactivity disorder pathophysiology: an important role for prefrontal cortex dysfunction. CNS Drugs 23 Suppl 1:33-41.

Arnsten AF, Ramos BP, Birnbaum SG, Taylor JR (2005) Protein kinase A as a therapeutic target for memory disorders: rationale and challenges. Trends Mol Med 11:121-128.

Beaulieu JM, Gainetdinov RR (2011) The physiology, signaling, and pharmacology of dopamine receptors. Pharmacol Rev 63:182-217.

Beavo JA (1995) Cyclic nucleotide phosphodiesterases: functional implications of multiple isoforms. Physiol Rev 75:725-748.

Belmaker RH, Ebstein RP, Biederman J, Stern R, Berman M, van Praag HM (1978) The effect of L-dopa and propranolol on human CSF cyclic nucleotides. Psychopharmacology (Berl) 58:307-310.

Bender AT, Beavo JA (2006) Cyclic nucleotide phosphodiesterases: molecular regulation to clinical use. Pharmacol Rev 58:488-520.

Blokland A, Schreiber R, Prickaerts J (2006) Improving memory: a role for phosphodiesterases. Curr Pharm Des 12:2511-2523.

Bollen E, Prickaerts J (2012) Phosphodiesterases in neurodegenerative disorders. IUBMB Life 64:965970.

Brink CB, Clapton JD, Eagar BE, Harvey BH (2008) Appearance of antidepressant-like effect by sildenafil in rats after central muscarinic receptor blockade: evidence from behavioural and neuro-receptor studies. J Neural Transm 115:117-125.

Calabresi P, Picconi B, Tozzi A, Ghiglieri V, Di Filippo M (2014) Direct and indirect pathways of basal ganglia: a critical reappraisal. Nat Neurosci 17:1022-1030.

Chudasama Y, Robbins TW (2006) Functions of frontostriatal systems in cognition: comparative neuropsychopharmacological studies in rats, monkeys and humans. Biol Psychol 73:19-38.

Conti M, Beavo J (2007) Biochemistry and physiology of cyclic nucleotide phosphodiesterases: essential components in cyclic nucleotide signaling. Annu Rev Biochem 76:481-511.

DeMarch Z, Giampa C, Patassini S, Bernardi G, Fusco FR (2008) Beneficial effects of rolipram in the R6/2 mouse model of Huntington's disease. Neurobiol Dis 30:375-387.

DeMarch Z, Giampa C, Patassini S, Martorana A, Bernardi G, Fusco FR (2007) Beneficial effects of rolipram in a quinolinic acid model of striatal excitotoxicity. Neurobiol Dis 25:266-273.

Ding L, Zhang C, Masood A, Li J, Sun J, Nadeem A, Zhang HT, O'Donnell JM, Xu Y (2014) Protective effects of phosphodiesterase 2 inhibitor on depression- and anxiety-like behaviors: involvement of antioxidant and anti-apoptotic mechanisms. Behav Brain Res 268:150-158.

Dodge-Kafka KL, Soughayer J, Pare GC, Carlisle Michel JJ, Langeberg LK, Kapiloff MS, Scott JD (2005) The protein kinase A anchoring protein mAKAP coordinates two integrated cAMP effector pathways. Nature 437:574-578.

Duinen MV, Reneerkens OA, Lambrecht L, Sambeth A, Rutten BP, Os JV, Blokland A, Prickaerts J (2015) Treatment of Cognitive Impairment in Schizophrenia: Potential Value of Phosphodiesterase Inhibitors in Prefrontal Dysfunction. Curr Pharm Des 21:3813-3828.

Esposito K, Reierson GW, Luo HR, Wu GS, Licinio J, Wong ML (2009) Phosphodiesterase genes and antidepressant treatment response: a review. Ann Med 41:177-185.

Ferre S, Quiroz C, Orru M, Guitart X, Navarro G, Cortes A, Casado V, Canela El, Lluis C, Franco R (2011) Adenosine $A 2 A$ receptors and $A 2 A$ receptor heteromers as key players in striatal function. Front Neuroanat 5. 
Francis SH, Blount MA, Corbin JD (2011) Mammalian cyclic nucleotide phosphodiesterases: molecular mechanisms and physiological functions. Physiol Rev 91:651-690.

Freund N, MacGillivilray HT, Thompson BS, Lukkes JL, Stanis JJ, Brenhouse HC, Andersen SL (2014) Sex-dependent changes in ADHD-like behaviors in juvenile rats following cortical dopamine depletion. Behav Brain Res 270:357-363.

Fujita M, Hines CS, Zoghbi SS, Mallinger AG, Dickstein LP, Liow JS, Zhang Y, Pike VW, Drevets WC, Innis RB, Zarate CA, Jr. (2012) Downregulation of brain phosphodiesterase type IV measured with $11 \mathrm{C}-(\mathrm{R})$-rolipram positron emission tomography in major depressive disorder. Biol Psychiatry 72:548-554.

Gerfen CR, Surmeier DJ (2011) Modulation of striatal projection systems by dopamine. Annu Rev Neurosci 34:441-466.

Gerfen CR, Engber TM, Mahan LC, Susel Z, Chase TN, Monsma FJ, Jr., Sibley DR (1990) D1 and D2 dopamine receptor-regulated gene expression of striatonigral and striatopallidal neurons. Science 250:1429-1432.

Greengard P (2001) The neurobiology of dopamine signaling. Biosci Rep 21:247-269.

Greengard P, Allen PB, Nairn AC (1999) Beyond the dopamine receptor: the DARPP-32/protein phosphatase-1 cascade. Neuron 23:435-447.

Gunaydin LA, Kreitzer AC (2015) Cortico-Basal Ganglia Circuit Function in Psychiatric Disease. Annu Rev Physiol.

Gurney ME, D'Amato EC, Burgin AB (2015) Phosphodiesterase-4 (PDE4) molecular pharmacology and Alzheimer's disease. Neurotherapeutics 12:49-56.

Haber SN, Rauch SL (2010) Neurocircuitry: a window into the networks underlying neuropsychiatric disease. Neuropsychopharmacology 35:1-3.

Hebb AL, Robertson HA (2008) PDEs as drug targets for CNS immune disorders. Curr Opin Investig Drugs 9:744-753.

Hebb AL, Robertson HA, Denovan-Wright EM (2008) Phosphodiesterase 10A inhibition is associated with locomotor and cognitive deficits and increased anxiety in mice. Eur Neuropsychopharmacol 18:339-363.

Heckman PR, Wouters C, Prickaerts J (2015a) Phosphodiesterase inhibitors as a target for cognition enhancement in aging and Alzheimer's disease: a translational overview. Curr Pharm Des 21:317-331.

Heckman PR, Blokland A, Ramaekers J, Prickaerts J (2015b) PDE and cognitive processing: beyond the memory domain. Neurobiol Learn Mem 119:108-122.

Houslay MD, Baillie GS, Maurice DH (2007) CAMP-Specific phosphodiesterase-4 enzymes in the cardiovascular system: a molecular toolbox for generating compartmentalized CAMP signaling. Circ Res 100:950-966.

Imanishi T, Sawa A, Ichimaru Y, Miyashiro M, Kato S, Yamamoto T, Ueki S (1997) Ameliorating effects of rolipram on experimentally induced impairments of learning and memory in rodents. Eur J Pharmacol 321:273-278.

Jurevicius J, Fischmeister R (1996) CAMP compartmentation is responsible for a local activation of cardiac Ca2+ channels by beta-adrenergic agonists. Proc Natl Acad Sci U S A 93:295-299.

Keravis T, Lugnier C (2012) Cyclic nucleotide phosphodiesterase (PDE) isozymes as targets of the intracellular signalling network: benefits of PDE inhibitors in various diseases and perspectives for future therapeutic developments. Br J Pharmacol 165:1288-1305.

Kritzer MD, Li J, Dodge-Kafka K, Kapiloff MS (2012) AKAPs: the architectural underpinnings of local cAMP signaling. J Mol Cell Cardiol 52:351-358.

Kuroiwa M, Snyder GL, Shuto T, Fukuda A, Yanagawa Y, Benavides DR, Nairn AC, Bibb JA, Greengard P, Nishi A (2012) Phosphodiesterase 4 inhibition enhances the dopamine D1 receptor/PKA/DARPP-32 signaling cascade in frontal cortex. Psychopharmacology (Berl) 219:1065-1079.

Lakics V, Karran EH, Boess FG (2010) Quantitative comparison of phosphodiesterase mRNA distribution in human brain and peripheral tissues. Neuropharmacology 59:367-374. 
Lukkes JL, Freund N, Thompson BS, Meda S, Andersen SL (2016) Preventative treatment in an animal model of ADHD: Behavioral and biochemical effects of methylphenidate and its interactions with ovarian hormones in female rats. Eur Neuropsychopharmacol 26:1496-1506.

Mattson MP, Chan SL, Duan W (2002) Modification of brain aging and neurodegenerative disorders by genes, diet, and behavior. Physiol Rev 82:637-672.

Maurice DH (2011) Subcellular signaling in the endothelium: cyclic nucleotides take their place. Curr Opin Pharmacol 11:656-664.

Mayr B, Montminy M (2001) Transcriptional regulation by the phosphorylation-dependent factor CREB. Nat Rev Mol Cell Biol 2:599-609.

Menniti FS, Chappie TA, Humphrey JM, Schmidt CJ (2007) Phosphodiesterase 10A inhibitors: a novel approach to the treatment of the symptoms of schizophrenia. Curr Opin Investig Drugs 8:5459.

Mongillo M, Tocchetti CG, Terrin A, Lissandron V, Cheung YF, Dostmann WR, Pozzan T, Kass DA, Paolocci N, Houslay MD, Zaccolo M (2006) Compartmentalized phosphodiesterase-2 activity blunts beta-adrenergic cardiac inotropy via an NO/cGMP-dependent pathway. Circ Res 98:226-234

Nishi A, Kuroiwa M, Shuto T (2011) Mechanisms for the modulation of dopamine $d(1)$ receptor signaling in striatal neurons. Front Neuroanat 5:43.

Nishino N, Kitamura N, Hashimoto T, Tanaka C (1993) Transmembrane signalling systems in the brain of patients with Parkinson's disease. Rev Neurosci 4:213-222.

O'Donnell JM, Xu Y (2012) Evidence for global reduction in brain cyclic adenosine monophosphate signaling in depression. Biol Psychiatry 72:524-525.

Padovan-Neto FE, Sammut S, Chakroborty S, Dec AM, Threlfell S, Campbell PW, Mudrakola V, Harms JF, Schmidt CJ, West AR (2015) Facilitation of corticostriatal transmission following pharmacological inhibition of striatal phosphodiesterase 10A: role of nitric oxide-soluble guanylyl cyclase-cGMP signaling pathways. J Neurosci 35:5781-5791.

Plattner F, Hayashi K, Hernandez A, Benavides DR, Tassin TC, Tan C, Day J, Fina MW, Yuen EY, Yan Z, Goldberg MS, Nairn AC, Greengard P, Nestler EJ, Taussig R, Nishi A, Houslay MD, Bibb JA (2015) The role of ventral striatal cAMP signaling in stress-induced behaviors. Nat Neurosci 18:1094-1100.

Puerta E, Hervias I, Barros-Minones L, Jordan J, Ricobaraza A, Cuadrado-Tejedor M, Garcia-Osta A, Aguirre N (2010) Sildenafil protects against 3-nitropropionic acid neurotoxicity through the modulation of calpain, CREB, and BDNF. Neurobiol Dis 38:237-245.

Ramos BP, Birnbaum SG, Lindenmayer I, Newton SS, Duman RS, Arnsten AF (2003) Dysregulation of protein kinase a signaling in the aged prefrontal cortex: new strategy for treating age-related cognitive decline. Neuron 40:835-845.

Reierson GW, Guo S, Mastronardi C, Licinio J, Wong ML (2011) cGMP Signaling, Phosphodiesterases and Major Depressive Disorder. Curr Neuropharmacol 9:715-727.

Rentero C, Monfort A, Puigdomenech P (2003) Identification and distribution of different mRNA variants produced by differential splicing in the human phosphodiesterase $9 \mathrm{~A}$ gene. Biochem Biophys Res Commun 301:686-692.

Richter W, Menniti FS, Zhang HT, Conti M (2013) PDE4 as a target for cognition enhancement. Expert Opin Ther Targets 17:1011-1027.

Rodriguez-Moreno A, Sihra TS (2013) Presynaptic kainate receptor-mediated facilitation of glutamate release involves Ca2+-calmodulin and PKA in cerebrocortical synaptosomes. FEBS Lett 587:788-792.

Rutter AR, Poffe A, Cavallini P, Davis TG, Schneck J, Negri M, Vicentini E, Montanari D, Arban R, Gray FA, Davies CH, Wren PB (2014) GSK356278, a potent, selective, brain-penetrant phosphodiesterase 4 inhibitor that demonstrates anxiolytic and cognition-enhancing effects without inducing side effects in preclinical species. J Pharmacol Exp Ther 350:153-163. 
Sancesario G, Giorgi M, D'Angelo V, Modica A, Martorana A, Morello M, Bengtson CP, Bernardi G (2004) Down-regulation of nitrergic transmission in the rat striatum after chronic nigrostriatal deafferentation. Eur J Neurosci 20:989-1000.

Sasaki H, Hashimoto K, Inada T, Fukui S, lyo M (1995) Suppression of oro-facial movements by rolipram, a cAMP phosphodiesterase inhibitor, in rats chronically treated with haloperidol. Eur J Pharmacol 282:71-76.

Schmidt CJ, Chapin DS, Cianfrogna J, Corman ML, Hajos M, Harms JF, Hoffman WE, Lebel LA, McCarthy SA, Nelson FR, Proulx-LaFrance C, Majchrzak MJ, Ramirez AD, Schmidt K, Seymour PA, Siuciak JA, Tingley FD, 3rd, Williams RD, Verhoest PR, Menniti FS (2008) Preclinical characterization of selective phosphodiesterase 10A inhibitors: a new therapeutic approach to the treatment of schizophrenia. J Pharmacol Exp Ther 325:681-690.

Schoffelmeer AN, Wardeh G, Mulder AH (1985) Cyclic AMP facilitates the electrically evoked release of radiolabelled noradrenaline, dopamine and 5-hydroxytryptamine from rat brain slices. Naunyn Schmiedebergs Arch Pharmacol 330:74-76.

Scott Bitner R (2012) Cyclic AMP response element-binding protein (CREB) phosphorylation: a mechanistic marker in the development of memory enhancing Alzheimer's disease therapeutics. Biochem Pharmacol 83:705-714.

Sharma S, Kumar K, Deshmukh R, Sharma PL (2013) Phosphodiesterases: Regulators of cyclic nucleotide signals and novel molecular target for movement disorders. Eur J Pharmacol 714:486-497.

Sibley DR, Monsma FJ, Jr., Shen Y (1993) Molecular neurobiology of dopaminergic receptors. Int Rev Neurobiol 35:391-415.

Siuciak JA (2008) The role of phosphodiesterases in schizophrenia : therapeutic implications. CNS Drugs 22:983-993.

Slattery M, Garvey M, Swedo S (2001) Frontal-subcortical circuits: a functional developmental approach. In: Frontal-Subcortical Circuits in Psychiatric and Neurological Disorders (Lichter D, \& Cummings, J., ed), pp 314-333. New York: Guilford Press.

Smith SM, Uslaner JM, Cox CD, Huszar SL, Cannon CE, Vardigan JD, Eddins D, Toolan DM, Kandebo M, Yao L, Raheem IT, Schreier JD, Breslin MJ, Coleman PJ, Renger JJ (2013) The novel phosphodiesterase 10A inhibitor THPP-1 has antipsychotic-like effects in rat and improves cognition in rat and rhesus monkey. Neuropharmacology 64:215-223.

Stangherlin A, Zaccolo M (2012) cGMP-cAMP interplay in cardiac myocytes: a local affair with farreaching consequences for heart function. Biochem Soc Trans 40:11-14.

Stangherlin A, Gesellchen F, Zoccarato A, Terrin A, Fields LA, Berrera M, Surdo NC, Craig MA, Smith G, Hamilton G, Zaccolo M (2011) cGMP signals modulate cAMP levels in a compartment-specific manner to regulate catecholamine-dependent signaling in cardiac myocytes. Circ Res 108:929-939.

Surmeier DJ, Carrillo-Reid L, Bargas J (2011) Dopaminergic modulation of striatal neurons, circuits, and assemblies. Neuroscience 198:3-18.

Surmeier DJ, Ding J, Day M, Wang Z, Shen W (2007) D1 and D2 dopamine-receptor modulation of striatal glutamatergic signaling in striatal medium spiny neurons. Trends Neurosci 30:228235.

Svenningsson P, Nishi A, Fisone G, Girault JA, Nairn AC, Greengard P (2004) DARPP-32: an integrator of neurotransmission. Annu Rev Pharmacol Toxicol 44:269-296.

Temel Y, Blokland A, Steinbusch HW, Visser-Vandewalle V (2005) The functional role of the subthalamic nucleus in cognitive and limbic circuits. Prog Neurobiol 76:393-413.

Threlfell S, West AR (2013) Review: Modulation of striatal neuron activity by cyclic nucleotide signaling and phosphodiesterase inhibition. Basal Ganglia 3:137-146.

Volicer L, Beal MF, Direnfeld LK, Marquis JK, Albert ML (1986) CSF cyclic nucleotides and somatostatin in Parkinson's disease. Neurology 36:89-92. 
Wang P, Wu P, Egan RW, Billah MM (2003) Identification and characterization of a new human type 9 cGMP-specific phosphodiesterase splice variant (PDE9A5). Differential tissue distribution and subcellular localization of PDE9A variants. Gene 314:15-27.

Wang ZZ, Zhang Y, Zhang HT, Li YF (2015) Phosphodiesterase: an interface connecting cognitive deficits to neuropsychiatric and neurodegenerative diseases. Curr Pharm Des 21:303-316.

West AR, Tseng KY (2011) Nitric Oxide-Soluble Guanylyl Cyclase-Cyclic GMP Signaling in the Striatum: New Targets for the Treatment of Parkinson's Disease? Front Syst Neurosci 5:55.

Wilson LS, Brandon NJ (2015) Emerging biology of PDE10A. Curr Pharm Des 21:378-388.

Wilson LS, Baillie GS, Pritchard LM, Umana B, Terrin A, Zaccolo M, Houslay MD, Maurice DH (2011) A phosphodiesterase 3B-based signaling complex integrates exchange protein activated by cAMP 1 and phosphatidylinositol 3-kinase signals in human arterial endothelial cells. J Biol Chem 286:16285-16296.

Winstanley CA, Eagle DM, Robbins TW (2006) Behavioral models of impulsivity in relation to ADHD: translation between clinical and preclinical studies. Clin Psychol Rev 26:379-395.

Wong ML, Whelan F, Deloukas P, Whittaker P, Delgado M, Cantor RM, McCann SM, Licinio J (2006) Phosphodiesterase genes are associated with susceptibility to major depression and antidepressant treatment response. Proc Natl Acad Sci U S A 103:15124-15129.

Yamashita N, Miyashiro M, Baba J, Sawa A (1997a) Rolipram, a selective inhibitor of phosphodiesterase type 4, pronouncedly enhanced the forskolin-induced promotion of dopamine biosynthesis in primary cultured rat mesencephalic neurons. Jpn J Pharmacol 75:91-95.

Yamashita N, Hayashi A, Baba J, Sawa A (1997b) Rolipram, a phosphodiesterase-4-selective inhibitor, promotes the survival of cultured rat dopaminergic neurons. Jpn J Pharmacol 75:155-159.

Yeterian EH, Pandya DN (1991) Prefrontostriatal connections in relation to cortical architectonic organization in rhesus monkeys. J Comp Neurol 312:43-67.

Zaccolo M, De Giorgi F, Cho CY, Feng L, Knapp T, Negulescu PA, Taylor SS, Tsien RY, Pozzan T (2000) A genetically encoded, fluorescent indicator for cyclic AMP in living cells. Nat Cell Biol 2:25-29.

Zhang C, Yu Y, Ruan L, Wang C, Pan J, Klabnik J, Lueptow L, Zhang HT, O'Donnell JM, Xu Y (2015) The roles of phosphodiesterase 2 in the central nervous and peripheral systems. Curr Pharm Des 21:274-290.

Zhang HT (2009) Cyclic AMP-specific phosphodiesterase-4 as a target for the development of antidepressant drugs. Curr Pharm Des 15:1688-1698.

Zhang HT (2010) Phosphodiesterase Targets for Cognitive Dysfunction and Schizophrenia--a New York Academy of Sciences Meeting. IDrugs 13:166-168.

Zinn CG, Bevilaqua LR, Rossato JI, Medina JH, Izquierdo I, Cammarota M (2009) On the requirement of nitric oxide signaling in the amygdala for consolidation of inhibitory avoidance memory. Neurobiol Learn Mem 91:266-272. 


\section{Chapter 2}

PDE and cognitive processing: beyond the memory domain

P.R.A. Heckman, A. Blokland, J.G. Ramaekers and J. Prickaerts Neurobiology of Learning and Memory (2015), 119, 108-122 


\begin{abstract}
Phosphodiesterase inhibitors (PDE-Is) enhance CAMP and/or cGMP signaling via reducing the degradation of these cyclic nucleotides. Both CAMP and cGMP signaling are essential for a variety of cellular functions and exert their effects both pre- and post-synaptically. Either of these second messengers relays and amplifies incoming signals at receptors on the cell surface making them important elements in signal transduction cascades and essential in cellular signaling in a variety of cell functions including neurotransmitter release and neuroprotection. Consequently, these processes can be influenced by PDE-Is as they increase CAMP and/or cGMP concentrations. PDE-Is have been considered as possible therapeutic agents to treat impaired memory function linked to several brain disorders, including depression, schizophrenia and Alzheimer's disease (AD). This review will, however, focus on the possible role of phosphodiesterases (PDEs) in cognitive decline beyond the memory domain. Here we will discuss the involvement of PDEs on three related domains: attention, information filtering (sensory- and sensorimotor gating) and response inhibition (druginduced hyperlocomotion). Currently, these are emerging cognitive domains in the field of PDE research. Here we discuss experimental studies and the potential beneficial effects of PDE-I drugs on these cognitive domains, as effects of PDE-Is on these domains could potentially influence effects on memory performance. Overall, PDE4 seems to be the most promising target for all domains discussed in this review.
\end{abstract}

Keywords: CAMP, cGMP, PDE, attention, gating, response inhibition 


\section{Phosphodiesterases and cognition}

\subsection{Cognitive decline}

One of the problems many people come to face with increasing age is a decline in cognitive functions (Mattson et al., 2002). The loss of cognitive functioning is even more serious in patients suffering from neuropathological conditions such as Alzheimer's disease (AD), depression and schizophrenia (Blaney, 1986; Frith, 1996). The need to develop drugs that counteract cognitive decline is of major importance since these deficits have a large impact on the quality of life of these patients. So far, several strategies have been described which could slow down cognitive decline. Research has focused on environmental and genetic factors that cause neuronal dysfunction and death or on enhancement of the ability of neurons to adapt (Mattson et al., 2002). Despite these strategies, there is still a great need for drugs that counteract the processes involved in the decline of cognitive functioning (Reneerkens et al., 2009).

For cognition enhancement or reversal of cognitive deficits, several drug targets, like the serotonergic, cholinergic, glutamatergic and monoaminergic neurotransmitter systems, have been suggested. All these neurotransmitter systems have shown to be involved in cognition. Furthermore, cognitive performance can be improved via numerous biological targets such as neuromodulators, hormones, intracellular molecules, plant extracts, and nutritional ingredients, which enhance neurotransmission, blood flow, glucose metabolism, or have free radical scavenging properties (Cahill et al., 1994; Davis and Squire, 1984; DeZazzo and Tully, 1995; Izquierdo et al., 1998; McGaugh, 1989; Messier, 2004; Parrott, 2005; Reneerkens et al., 2009). There has been an increasing interest in the drugs that inhibit the phosphodiesterase enzyme to improve cognitive performance in animals and man (Blokland et al., 2012; Bollen and Prickaerts, 2012; Reneerkens et al., 2009).

\subsection{Phosphodiesterases}

Phosphodiesterases (PDEs) are enzymes that play a major role in cell signaling by hydrolyzing the second messengers cyclic adenosine monophosphate (cAMP) and/or cyclic guanosine monophosphate (cGMP) throughout the body and brain (Beavo, 1995; Lugnier, 2006). Phosphodiesterase inhibitors (PDE-Is) reduce the degradation of CAMP and/or cGMP, leading to increased concentration of CAMP and/or cGMP (Beavo, 1995). These signals will then have a prolonged effect on the signaling pathways in neurons. 
Currently, PDEs constitute 11 gene-related families of isozymes (see Table 1). In total, there are estimated to be over 100 specific human PDEs (Bender and Beavo, 2006). Different PDE families can be distinguished based on their affinity for the second messengers cAMP, cGMP or both (see Table 1) (Beavo, 1995).

Table 1. Overview of the different PDE families, the related genes, property and the substrate of the PDE (Bender and Beavo, 2006).

\begin{tabular}{|l|l|l|l|}
\hline Type & Genes & Property & Substrate \\
\hline PDE1 & A, B, C & Ca ${ }^{2+}$-CaM-stimulated & cAMP/cGMP \\
PDE2 & A & cGMP-stimulated & cAMP/cGMP \\
PDE3 & A, B & cGMP-inhibited & cAMP/cGMP \\
PDE4 & A, B, C, D & cAMP-specific & cAMP \\
PDE5 & A & cGMP-specific & cGMP \\
PDE6 & A, B, C & Photoreceptor & cGMP \\
PDE7 & A, B & cAMP high affinity & cAMP \\
PDE8 & A, B & cAMP high affinity & cAMP \\
PDE9 & A & cGMP high affinity & cGMP \\
PDE10 & A & cAMP-inhibited & cAMP/cGMP \\
PDE11 & A & Dual substrate & cAMP/cGMP \\
\hline
\end{tabular}

\subsection{Second messengers}

Second messengers relay and amplify incoming signals at receptors on the cell surface making them important elements in signal transduction cascades. The second messengers CAMP and cGMP are essential in cellular signaling in a variety of cellular functions including neurotransmitter release, neuroplasticity and neuroprotection, as described below (Francis et al., 2011). Consequently, these processes can be influenced by PDE-Is as they increase CAMP and/or cGMP concentrations.

CAMP is synthesized from adenosine triphosphate (ATP) by adenylyl cyclase (AC). The latter is activated by calmodulin-dependent protein kinase II (CaMKII) after $\mathrm{Ca}^{2+}$ influx or directly by an activated G-coupled protein receptor. cAMP can activate protein kinase A (PKA) which phosphorylates the cAMP response element-binding protein (CREB), and can thereby affect transcription of genes related to synaptic plasticity and neurogenesis, like brain-derived neurotrophic factor (BDNF) (Scott Bitner, 2012). On the other hand, cGMP is derived from guanosine triphosphate (GTP) by guanylyl cyclase (GC), which in turn is activated by nitric oxide (NO). NO is produced by NO 
synthase (NOS) after $\mathrm{Ca}^{2+}$ influx. The NO/cGMP pathway activates protein kinase $\mathrm{G}$ (PKG), which can also induce CREB phosphorylation (Lu et al., 1999), likely via modulation of the CAMP/PKA pathway (Bollen et al., 2014)

Since PDE-Is postsynaptically affect transcription of genes related to synaptic plasticity and neurogenesis, these effects are long-lasting and probably not involved in the short-lasting actions related to cognitive domains to be discussed in this review. As such, plasticity effects are more likely to play an important role in long-term potentiation (LTP), which is assumed to be the substrate of memory (Sarvey et al., 1989), and the formation of memories. Though, the enzyme AC is also present presynaptically and elevation of CAMP has been found to result in the synthesis and/or release of several neurotransmitters including glutamate and dopamine (DA) (Imanishi et al., 1985). This might be mediated via a presynaptic CaMK/CAMP/PKA cascade and hence signal transduction is influenced. Also, NO is known to act as a retrograde messenger and can thus stimulate presynaptic GC. Linked to this, via a cGMP/PKG cascade, the synthesis and/or release of neurotransmitters including glutamate and DA can also be influenced (Arancio et al., 1995; Sanchez et al., 2002), and thus again signal transduction. Figure 1 provides a schematic overview of the pre- and postsynaptic cellular processes related to the second messengers CAMP and cGMP involved in signal transduction.

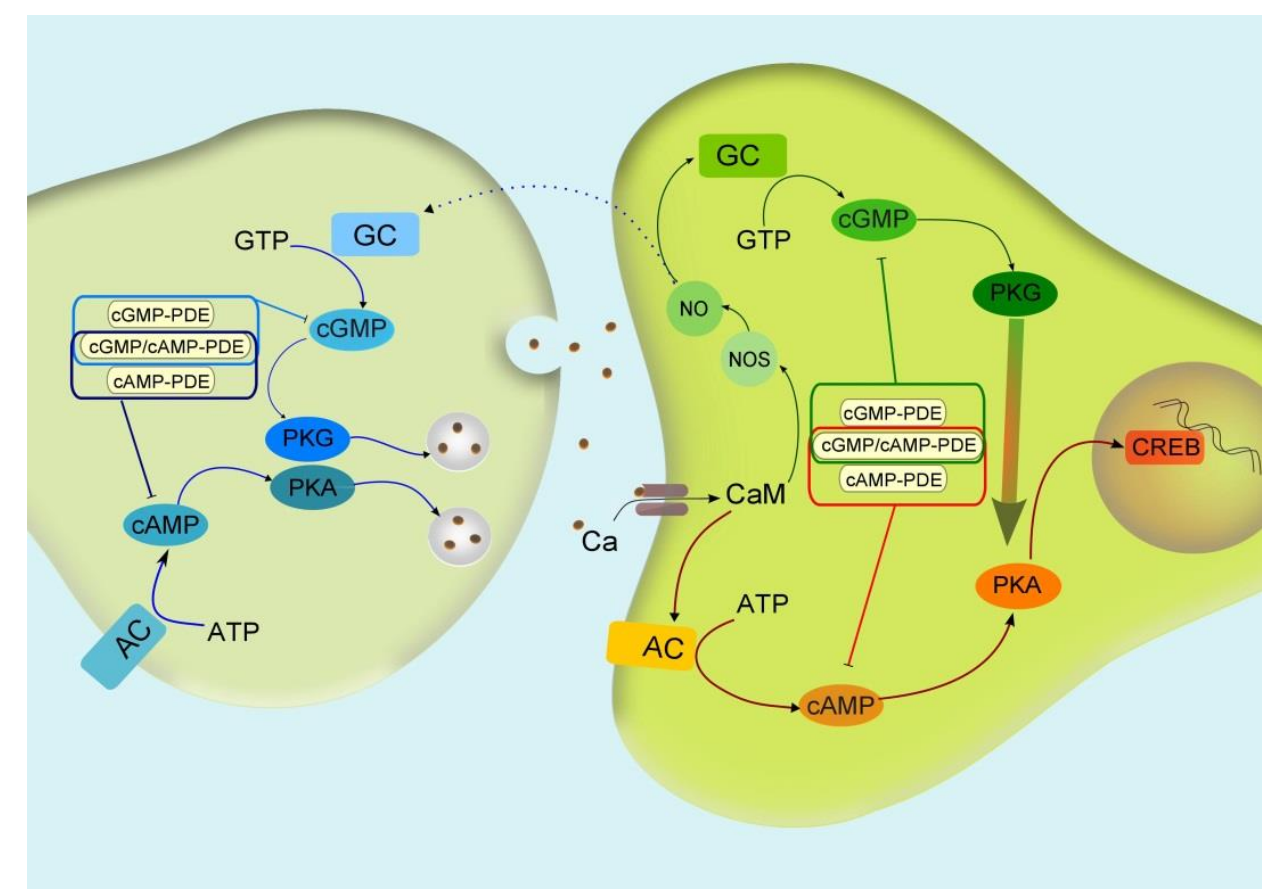

Fig. 1 Schematic diagram of pre- and postsynaptic cellular processes related to the second messengers cAMP and CGMP involved in LTP-related signal transduction.

\subsection{Localization}


Table 2 provides a short overview of the localization of the different PDEs in the brain of rodents and humans based on mRNA expression and situ histochemistry (Lakics et al, 2010; Pérez-Torres et al, 2010).

Table 2. Localization of the different phosphodiesterases (PDEs) in the brain of rodents and humans in adulthood (adapted from Prickaerts, 2010; based on Lakics et al, 2010; Pérez-Torres et al, 2010).

\begin{tabular}{|c|c|}
\hline PDE & Localization in the Brain \\
\hline PDE1A-C & $\begin{array}{l}\text { Hippocampus, cortex, olfactory bulb, striatum } \\
\text { (highest expression levels), thalamus, } \\
\text { amygdala, cerebellum; Expression levels are in } \\
\text { general highest for } 1 \mathrm{~A} \text { and lowest for } 1 \mathrm{C}\end{array}$ \\
\hline PDE2A & $\begin{array}{l}\text { Hippocampus, cortex, striatum, hypothalamus, } \\
\text { amygdala, midbrain }\end{array}$ \\
\hline PDE3 & Throughout the brain low expression levels \\
\hline PDE4A-D & $\begin{array}{l}\text { Hippocampus, cortex, olfactory bulb, striatum, } \\
\text { thalamus, hypothalamus, amygdala, midbrain, } \\
\text { cerebellum; Expression levels are in general } \\
\text { highest for 4A-4D (differs per brain structure) } \\
\text { and lowest for 4C }\end{array}$ \\
\hline PDE5A & Hippocampus, cortex, cerebellum \\
\hline PDE6 & Pineal gland \\
\hline PDE7A-B & $\begin{array}{l}\text { Hippocampus, cortex, olfactory bulb, striatum, } \\
\text { thalamus, hypothalamus, midbrain; Expression } \\
\text { levels are in general highest for 7B }\end{array}$ \\
\hline PDE8A-B & $\begin{array}{l}\text { Hippocampus, cortex, olfactory bulb, striatum, } \\
\text { thalamus, hypothalamus, midbrain; Expression } \\
\text { levels are in general highest for } 8 \mathrm{~B}\end{array}$ \\
\hline PDE9A & $\begin{array}{l}\text { Hippocampus, cortex, olfactory bulb, striatum, } \\
\text { thalamus, hypothalamus, amygdala, midbrain, } \\
\text { cerebellum }\end{array}$ \\
\hline PDE10A & $\begin{array}{l}\text { Hippocampus, cortex, striatum (highest } \\
\text { expression levels), midbrain, cerebellum }\end{array}$ \\
\hline PDE11A & Throughout the brain low expression levels \\
\hline
\end{tabular}


Only clear expression levels are taken into consideration. Note that this table does not provide information with respect to the level of expression (protein or mRNA) of the different PDEs.

\subsection{Beyond the memory domain}

Recently, PDE-Is are receiving increased attention as possible therapeutic tools for treatment of cognitive decline. The effects on memory processes have received most attention when it comes to the application of PDE-Is as therapeutic agents (for an overview see Blokland et al., 2012; Reneerkens et al., 2009), since impaired memory functioning is linked to several disorders, including depression, schizophrenia, Alzheimer's disease (Blaney, 1986; Folstein and Whitehouse, 1983; Frith, 1996). This review will, however, focus on the possible role of PDEs in cognitive decline beyond the memory domain. Here we will discuss the involvement of PDEs on three related domains: attention, information filtering (sensory and sensorimotor gating) and response inhibition (drug-induced hyperlocomotion). Currently, these are emerging cognitive domains in the field of PDE research. Here we discuss experimental studies and the potential beneficial effects of PDE-I drugs on these cognitive domains.

\section{Attention}

\subsection{Attentional concepts and biology}

Posner and Petersen (Fan and Posner, 2004; Petersen and Posner, 2012; Posner and Petersen, 1990) describe the concept that is referred to as 'attention' in terms of three basic concepts. The first concept encompasses that "the attention system is anatomically separate from processing systems, which handle incoming stimuli, make decisions, and produce outputs". The second concept states that "attention utilizes a network of anatomical areas". The third concept comes down to these anatomical areas carrying out different attentional processes that can be specified in cognitive terms.

The most unique aspect is the anatomical basis of the attention system: divided into three networks, each representing a different set of attentional processes. The first component contains mainly subcortically located arousal and alerting networks, mainly the ascending reticular activating system, and project to the whole brainstem and thalamus and, through the striatum, up to the limbic system to form cortical projections. The main function of this component is the activation and synchronization of the cortex during behavior and motivation, and has affinity for distinctive stimuli. The second component is the mixed cortical-subcortical orienting network which detects novel stimuli (superior colliculi), filters out irrelevant stimuli (pulvinar) or disengages attentional focus (posterior parietal cortex). The third attentional component is the executive attentional network. 
This involves frontal brain structures for generation of voluntary saccades (frontal eye fields), induces motor intention (premotor cortex), is linked to working memory (dorsolateral prefrontal cortex (dIPFC) or medial prefrontal cortex (mPFC) in rodents (Uylings et al., 2003)) and is modulated by the anterior cingulate cortex (ACC) (Fan and Posner, 2004; Petersen and Posner, 2012; Posner and Petersen, 1990).

\subsection{PDE inhibitors and attention}

Abundant PDEs can be found in the many human brain area's involved in the attention network including the thalamus, striatum and prefrontal cortex (PFC) (Lakics et al., 2010). However, so far only a few studies have been conducted investigating the effects of PDE inhibition on attention in both animals and humans (see Table 3). Of note, most animal tests for attention tap into the executive attention network but studies generally do not specify any clear distinction between the different components of attention.

Table 3. Overview studies testing the effects of PDE inhibition on attention-related functions.

\begin{tabular}{|c|c|c|c|c|}
\hline Task & Model (species) & Treatment & Results & Reference \\
\hline Latent inhibition & $\begin{array}{l}\text { MK-801-induced } \\
\text { deficit model (0.5 } \\
\mathrm{mg} / \mathrm{kg} \text {, i.p.)(mice) }\end{array}$ & $\begin{array}{l}\text { PDE4-I: Rolipram } \\
\text { (0.05 and } 0.075 \\
\mathrm{mg} / \mathrm{kg} \text {, i.p.) }\end{array}$ & $\begin{array}{l}\text { Rolipram } 0.075 \\
\mathrm{mg} / \mathrm{kg} \text { restored } \\
\text { levels of latent } \\
\text { inhibition }\end{array}$ & $\begin{array}{l}\text { Davis \& Gould, } \\
2005\end{array}$ \\
\hline Latent inhibition & $\begin{array}{l}\text { Bupropion- } \\
\text { induced deficit } \\
\text { model ( } 1.0 \text { and } \\
4.0 \mathrm{mg} / \mathrm{kg} \text {, i.p.), } \\
\text { amphetamine- } \\
\text { induced deficit } \\
\text { model }(0.5,1.0 \text {, } \\
2.5 \mathrm{mg} / \mathrm{kg} \text {, } \\
\text { i.p.)and } \\
\text { GBR12783- } \\
\text { induced deficit } \\
\text { model (5.0, } 15.0 \\
\mathrm{mg} / \mathrm{kg} \text {, } \\
\text { n.p.)(mice) }\end{array}$ & $\begin{array}{l}\text { PDE4-I: Rolipram } \\
\text { (0.5 mg/kg, i.p.) }\end{array}$ & $\begin{array}{l}\text { Rolipram restored } \\
\text { levels of latent } \\
\text { inhibition in all } \\
\text { three deficit } \\
\text { models }\end{array}$ & $\begin{array}{l}\text { Lipina \& Roder, } \\
2009\end{array}$ \\
\hline Latent inhibition & $\begin{array}{l}\text { Amphetamine- } \\
\text { induced deficit } \\
\text { model ( } 2.5 \\
\mathrm{mg} / \mathrm{kg}, \text { i.p.) and } \\
\text { disruption } \\
\text { induced by } \\
\text { increased \# of } \\
\text { conditioning trials } \\
\text { (mice) }\end{array}$ & $\begin{array}{l}\text { PDE7-I: VP1.15 } \\
\text { (3.0 mg/kg, i.p.) }\end{array}$ & $\begin{array}{l}\text { In both deficit } \\
\text { models VP1.15 } \\
\text { enhanced } \\
\text { disrupted latent } \\
\text { inhibition }\end{array}$ & Lipina et al., 2013 \\
\hline Latent inhibition & PDE10A knockout & Not applicable & Latent inhibition & Piccart et al., \\
\hline
\end{tabular}




\begin{tabular}{|c|c|c|c|c|}
\hline & (mice) & & $\begin{array}{l}\text { was impaired in } \\
\text { KO mice } \\
\text { compared to wild } \\
\text { type }\end{array}$ & 2014 \\
\hline $\begin{array}{l}\text { Spatial auditory } \\
\text { attention task }\end{array}$ & $\begin{array}{l}\text { Unimpaired } \\
\text { young (human) }\end{array}$ & $\begin{array}{l}\text { PDE5-I: Sildenafil } \\
\text { (100 mg, oral) }\end{array}$ & $\begin{array}{l}\text { No effects on } \\
\text { behavioral } \\
\text { measures, } \\
\text { amplitude } \\
\text { enhancement Nd- } \\
\text { effect + P3 effect }\end{array}$ & $\begin{array}{l}\text { Schultheiss et al., } \\
2001\end{array}$ \\
\hline $\begin{array}{l}\text { Periphery } \\
\text { vigilance test } \\
\text { combined with a } \\
\text { tracking task }\end{array}$ & $\begin{array}{l}\text { Unimpaired } \\
\text { (human) }\end{array}$ & $\begin{array}{l}\text { PDE5-I: Sildenafil } \\
\text { (100 mg, oral) }\end{array}$ & $\begin{array}{l}\text { Average output of } \\
\text { tracking was } \\
\text { lower in sildenafil } \\
\text { group }\end{array}$ & Grass et al., 2001 \\
\hline $\begin{array}{l}\text { Conditioned } \\
\text { avoidance } \\
\text { attention task }\end{array}$ & $\begin{array}{l}\text { Scopolamine- } \\
\text { induced deficit } \\
\text { model ( } 0.13 \\
\mathrm{mg} / \mathrm{kg} \text {, s.c.)(rats) }\end{array}$ & $\begin{array}{l}\text { PDE9-I: PF- } \\
04447943 \text { (0.1- } \\
3.0 \mathrm{mg} / \mathrm{kg} \text {, i.p.) }\end{array}$ & $\begin{array}{l}\text { Only } 1 \mathrm{mg} / \mathrm{kg} \text { PF- } \\
04447943 \\
\text { reversed } \\
\text { scopolamine } \\
\text { deficit on } 1 \text { and } 3 \\
\text { sec trials }\end{array}$ & $\begin{array}{l}\text { Vardigan et al., } \\
2011\end{array}$ \\
\hline $\begin{array}{l}\text { Attentional set- } \\
\text { shifting }\end{array}$ & $\begin{array}{l}\text { PCP-induced } \\
\text { deficit model (5.0 } \\
\mathrm{mg} / \mathrm{kg} \text {, i.p.)(rats) }\end{array}$ & $\begin{array}{l}\text { PDE10-I: } \\
\text { Papaverine (3.0, } \\
10.0 \text { and } 30.0 \\
\mathrm{mg} / \mathrm{kg} \text {, i.p.) }\end{array}$ & $\begin{array}{l}\text { All doses of } \\
\text { papaverine } \\
\text { restored deficit in } \\
\text { EDS performance }\end{array}$ & $\begin{array}{l}\text { Rodefer, et al., } \\
2005\end{array}$ \\
\hline $\begin{array}{l}\text { Attentional set- } \\
\text { shifting }\end{array}$ & $\begin{array}{l}\text { PCP-induced } \\
\text { deficit model (5.0 } \\
\mathrm{mg} / \mathrm{kg} \text {, i.p.)(rats) }\end{array}$ & $\begin{array}{l}\text { PDE2-I: BAY 60- } \\
7550 \text { (0.3-3 } \\
\mathrm{mg} / \mathrm{kg}, \text { p.o.) }\end{array}$ & $\begin{array}{l}3 \mathrm{mg} / \mathrm{kg} \text { restored } \\
\text { deficit in EDS } \\
\text { performance }\end{array}$ & $\begin{array}{l}\text { Rodefer et al., } \\
2012\end{array}$ \\
\hline $\begin{array}{l}\text { Attentional set- } \\
\text { shifting }\end{array}$ & $\begin{array}{l}\text { PCP-induced } \\
\text { deficit model ( } 5.0 \\
\mathrm{mg} / \mathrm{kg} \text {, i.p.)(rats) }\end{array}$ & $\begin{array}{l}\text { PDE4-I: rolipram } \\
(0.003-0.03 \\
\mathrm{mg} / \mathrm{kg} \text {, i.p.) }\end{array}$ & $\begin{array}{l}0.1 \mathrm{mg} / \mathrm{kg} \\
\text { restored deficit in } \\
\text { EDS performance }\end{array}$ & $\begin{array}{l}\text { Rodefer et al., } \\
2012\end{array}$ \\
\hline $\begin{array}{l}\text { Attentional set- } \\
\text { shifting }\end{array}$ & $\begin{array}{l}\text { PCP-induced } \\
\text { deficit model (5.0 } \\
\mathrm{mg} / \mathrm{kg} \text {, i.p.)(rats) }\end{array}$ & $\begin{array}{l}\text { PDE5-I: sildenafil } \\
\text { (0.3-3 mg/kg, i.p.) }\end{array}$ & $\begin{array}{l}3 \mathrm{mg} / \mathrm{kg} \text { restored } \\
\text { deficit in EDS } \\
\text { performance }\end{array}$ & $\begin{array}{l}\text { Rodefer et al., } \\
2012\end{array}$ \\
\hline $\begin{array}{l}\text { Attentional set- } \\
\text { shifting }\end{array}$ & $\begin{array}{l}\text { PCP-induced } \\
\text { deficit model ( } 5.0 \\
\mathrm{mg} / \mathrm{kg} \text {, i.p.)(rats) }\end{array}$ & $\begin{array}{l}\text { PDE10-I: } \\
\text { papaverine (1-10 } \\
\mathrm{mg} / \mathrm{kg} \text {, i.p.) }\end{array}$ & $\begin{array}{l}10 \mathrm{mg} / \mathrm{kg} \\
\text { restored deficit in } \\
\text { EDS performance }\end{array}$ & $\begin{array}{l}\text { Rodefer et al., } \\
2012\end{array}$ \\
\hline
\end{tabular}

i.p. $=$ intra peritoneal; i.m. $=$ intra muscular; s.c. $=$ subcutaneous; n.p. $=$ not provided

\subsubsection{PDE2 inhibitors}

Only one study examined the effects of a PDE2-I in an attention model that is assumed to measure attentional deficits in schizophrenia (Rodefer et al., 2012). In this test model phencyclidine (PCP) treatment resulted in an increased number of trials when the rats had to learn an extra-dimensional shift. In this study BAY 60-7550 attenuated the PCP-induced deficit.

\subsubsection{PDE 4 inhibitors}


In 2005 the first study was conducted by (Davis and Gould, 2005). The latent inhibition (LI) paradigm was used to examine attention and study cognitive deficits associated with schizophrenia. $\mathrm{LI}$ is the phenomenon by which prior exposure to a non-rewarding conditioned stimulus (CS) decreases the salience of the CS when it is later paired with an unconditioned stimulus (US) (Weiner, 2003). This test requires attentional abilities. A deficit in selective attention results in better learning in this task. In their study, the CAMP-specific PDE4-I rolipram attenuated the disruptive effect of the N-methyl- D -aspartic acid (NMDA) antagonist MK-801, a commonly used deficit model in attention research, on $\mathrm{LI}$ in mice, thus linking PDE-Is for the first time to attention research. In another study using the same paradigm, rolipram reversed the $\mathrm{LI}$ deficits induced by bupropion (DA and norepinephrine (NE) reuptake inhibitor and noncompetitive nicotinic antagonist) treatment in mice (Lipina and Roder, 2009). Rolipram was also found to reverse the PCP-induced deficits in extra dimensional attentional set-shift learning (a test model for schizophrenia) (Rodefer et al., 2012). Taken together, these data show that a variety of test models show an improved attentional performance after PDE4-I treatment.

\subsubsection{PDE 5 inhibitors}

Two human studies examined the effects of PDE5 inhibition on attention. In 2001 both these studies were conducted using the CGMP-specific PDE5-I sildenafil. In the first study behavioral patterns and event-related potentials (ERPs) were recorded in a spatial auditory attention task (Schultheiss et al., 2001). While behavioral patterns did not reveal any overt effects of sildenafil, auditory ERPs were indicative of an enhanced ability to focus attention and to select relevant target stimuli in the sildenafil condition. The other study encompassed a pilot study ( $n=6)$ (Grass et al., 2001). These data could suggest that the attention performance was enhanced in the sildenafil condition, but it should be noted that the reported effects did not reach statistical significance. One animal study showed that sildenafil improved set-shifting learning in rats (Rodefer et al., 2012).

\subsubsection{PDE 7 inhibitors}

The dual inhibitor of CAMP-specific PDE7 and glycogen synthase kinase 3 (GSK-3), VP1.15, was able to ameliorate the disrupted $\mathrm{LI}$ induced by the increased number of conditioning trials and reversed an amphetamine-induced LI deficit in mice (Lipina et al., 2013). These data indicate that VP1.15 has an effect in models of early attention processing. However, further studies are needed to be shown to what extend these effects can be attributed to inhibition of PDE7 or GSK-3.

\subsubsection{PDE 9 inhibitors}


Vardigan and coworkers (Vardigan et al., 2011) showed that the selective cGMP-specific PDE9-I PF04447943 attenuated a scopolamine-induced deficit in the conditioned avoidance attention task (CAAT) in rats. In this experiment animals were selected on basis of their performance in this task. After this titration this study demonstrated efficacy of PDE9-I treatment in this avoidance task (Vardigan et al., 2011). These findings suggest that PDE9-I may reverse a cholinergic deficit in attention.

\subsubsection{PDE 10 inhibitors}

Rodefer et al (2005) showed that acute treatment with the PDE10A-I papaverine reversed phencyclidine (PCP)-induced deficits in extra dimensional attentional set-shift learning (replicated in Rodefer et al., 2012). Thus, papaverine improved attentional functions in this schizophrenia model. A more recent study by Piccart et al. (2014) measured LI via conditioned taste aversion in PDE10A knockout mice. PDE10A -/- deficient animals showed impaired $\mathrm{LI}$ as indicated by the aversion index. The data revealed that wild type animals showed decreased conditioning to saccharin that had been tasted before conditioning, as expected in LI. PDE10A -/- deficient animals however did not show differences in conditioning to saccharine, when pre-exposed, indicative of impaired LI. Taken together these data suggest a role of PDE10 in attentional functions in preclinical schizophrenia models.

\subsubsection{Miscellaneous}

Although not directly related to PDE inhibition, a study by Lesch et al. revealed an interesting relation between the PDE4D6 gene and attention-deficit/hyperactivity disorder (ADHD) (Lesch et al., 2010). In this study they performed a genome-wide copy number variation analysis in ADHD in an extended pedigree. They found that the PDE4D6 gene was potentially influencing ADHD-related psychopathology and was involved in aberrations inherited from affected parents. Furthermore, Paine and colleagues (Paine et al., 2009) showed that inhibition of PKA within the mPFC of rats, a region comparable to the dIPFC in humans (Uylings et al., 2003), produces inattention and hyperactivity. Since the level of the second messenger cAMP is directly related to PKA activity, a direct link between PDE4 inhibition and increased attention appears likely. Or more in general, cAMP specific PDEs that are located in frontal cerebral regions, i.e. PDE1, PDE2, PDE4 and PDE8, could be considered as interesting targets for PDE-Is in enhancing attention.

\subsection{Conclusion PDE inhibitors and Attention}

In conclusion, although highly variable in type of PDE-I, task type, read-out parameters and (deficit) models used, all animal studies into PDE inhibition and attention show a congruent pattern. 
Inhibitors of PDE4, 5, 7, 9 and 10 all show positive effects on the measures of attention investigated. The most used model of attention in PDE animal research is LI. Within this model different deficit models are used to induce an $\mathrm{LI}$ impairment, i.e. MK-801, PCP, bupropion, scopolamine or amphetamine. Some human studies with PDE5-Is appear to support these findings in animal research (but see Reneerkens et al., 2013).

The most interesting PDE-Is for improving attention based on their presence in the abundant attention network and the scarce data available, appear PDE4-Is and PDE5-Is as rolipram and sildenafil showed best results, respectively (see Table 3 for an overview). The field of attention research is hampered by inconsistencies in methods used and lack of overall consensus of the attention network itself. This led to the fact that studies into attention and PDE inhibition do not select target brain areas to be stimulated, but use existing or new attention tasks and generally try to stimulate cholinergic, dopaminergic and glutamatergic neurotransmission to find an effect. Most attention tasks are stimulus-driven and therefore use bottom-up processing. Bottom-up processing involves mostly orienting and alerting networks. However, if a response requires executive attention top-down processing plays a role as well. It is therefore very hard to distinguish between different brain areas involved in the attentional component of a task and consequently which brain area should specifically be stimulated. The advantage of PDE-Is is that they do not focus on one neurotransmitter system but can enhance intracellular signaling in all neuronal systems containing the particular PDE subtype being targeted, either glutamatergic, cholinergic or otherwise. Likewise, taking into consideration the localization of the different PDE subfamilies, knowledge of the target area is required to select the appropriate PDE-I. The latter is a challenge for attention tasks. Each behavioral task may activate (partly) different brain areas so that several distinct types of PDE-Is would be suited for each behavioral attention task. Nevertheless, based on human PDE expression patterns in the overall attentional network, PDE2-Is, PDE4-Is and PDE8-Is are most likely to show attention enhancing effects (Lakics et al., 2010). PDE5, though, is generally low expressed in the brain, yet results from human studies using the PDE5-I sildenafil appear positive. However, the PDE5I vardenafil showed no results in humans after acute treatment. Consequently, one should be reserved when arguing that PDE5-Is are attention enhancers. PDE4-Is seem to be more promising but, yet again more studies are needed to substantiate this claim.

Several issues have to be considered in the field of attention and PDE-I research. Firstly, the number of studies that examined the effects of PDE-Is on attention are relatively scarce. Moreover, there are different types of attention and the test paradigms are quite heterogeneous which presently makes it difficult drawing firm conclusions with respect to PDE-Is and attention. A second main issue relates 
to the underlying neurobiology of attention. In attention research there is the lack of overall consensus of what systems and brain areas make up the attention system. Next to Posner's theory there are other models of attention available (e.g. Knudsen, 2007). In theory, stimulation of an area within any of these extensive networks could lead to enhanced attentional performance. Therefore, it is not clear which brain area is effectively mediating the positive effects of a PDE-I on cognition. In most studies, attention tasks lack specification of which brain areas are involved in the task. Instead, the focus is mainly on boosting a particular neurotransmitter system. Especially the glutamatergic system, including the NMDA receptor, receives most attention in relation to disturbed attentional functioning in schizophrenia (e.g. Davis and Gould, 2005; Rodefer et al., 2005). Also the cholinergic and dopaminergic neurotransmitter systems are investigated within this context (e.g. Lipina and Roder, 2009; Vardigan et al., 2011).

Of note, another approach is provided by pharmacological treatments of ADHD, an attention-related disorder. Stimulant drugs such as methylphenidate (Ritalin) and amphetamine (Adderall) improve the attention of individuals with ADHD and can enhance attention in healthy people as well (Lakhan and Kirchgessner, 2012; Mehta et al., 2000). Methylphenidate increases activity in the PFC and attentionrelated areas of the parietal cortex during challenging mental tasks (Berridge et al., 2006; Mehta et al., 2000). These are the same areas that have been demonstrated to have shrunken in volume in ADHD brains (Castellanos et al., 2002). These studies indicate the PFC and parietal cortex as relevant brain areas for attentional functioning. Several PDEs can be found within these areas including PDE1, PDE2, PDE4 and PDE8. Therefore, these PDEs are interesting targets for attention enhancement, of which only PDE4 has received attention in this respect.

\section{Gating}

\subsection{Gating concepts and biology}

In this section of our review we will focus on another cognitive domain termed 'gating' including both sensory gating and sensorimotor gating. Sensory gating is an automatic process involved in information processing. More specifically, it is an adaptive mechanism of the central nervous system that prevents overstimulation of higher cortical areas and helps filtering sensory information (e.g. Cromwell, Mears, Wan, and Boutros, 2008). The standard paradigm assessing this mechanism consists of two identical auditory stimuli that are presented with an inter stimulus interval (ISI) between 0.5 and $2 \mathrm{~s}$ and an inter trial interval (ITI) of at least $8 \mathrm{~s}$ (Cromwell et al., 2008; Hajos, 2006). In healthy individuals (humans as well as animals) the response to the second stimulus (S2) will be 
smaller than the response to the first stimulus (S1). Of note, the duration of the ISI is crucial; if it is shorter than $0.5 \mathrm{~s}$ or longer than $2 \mathrm{~s}$, sensory gating will not be elicited.

Sensory gating can be observed throughout the brain in areas in all four lobes in both hemispheres, as well as, subcortical structures capable of eliciting a P50 response. Almost every sensory signal, except olfaction, entering the brain must pass through a thalamic "gate" before it is relayed to the other parts of the brain, including the hippocampus and the cortex contributing to gating of irrelevant stimuli. Furthermore, frontal inhibitory output, as well as, locally released inhibitory neurotransmitter, both as a response to the first stimulus, contribute to inhibition of the response to the second stimulus (Freedman et al., 1991). Extensive research has shown that the process of sensory gating is disrupted in patients suffering from clinical disorders including schizophrenia and AD (e.g. Adler et al., 1982; Ally et al., 2006; Javitt, 2009; Jessen et al., 2001).

The responses evoked by this auditory sensory gating paradigm can be assessed using electroencephalographic (EEG) and ERP measurements. In humans, the P50, also known as P1, is considered to be the main ERP component related to sensory gating (e.g. Chang et al., 2011; Dalecki et al., 2011). In addition, the N100 (N1) and P200 (P2) might also be affected (e.g. Boutros et al., 2009; Lijffijt et al., 2009). There is still a debate about which ERP component in rats is possibly the functional equivalent of the P50 in humans (de Bruin et al., 2001). Some researchers suggest that the P13 (P1) (e.g. Miyazato et al., 1999) is the most suitable candidate, whereas others assume it is the N40 (N1) or P60 (P2) (e.g. Mears, Klein, and Cromwell, 2006; Zhou, Ma, Liu, Chen, He, and Miao, 2008). It has also been suggested that the entire P1-N1-P2 complex is involved in the auditory sensory gating paradigm in rats just as in humans (e.g. Broberg et al., 2010; Mears et al., 2009; Witten et al., 2014).

Sensorimotor gating can be measured via one of the most prominent behaviors studied in vertebrates called the 'startle response'. The startle response is a fast contraction of body muscles caused by a sudden acoustic, tactile, or visual stimulus mediated by simple neuronal circuitry (Koch, 1999). It is interpreted to be an evolutionarily conserved form of protection against potential danger and predators. Increase of the acoustically generated startle (commonly called the acoustic startle response; ASR) is known to have different causes such as sensitization, fear-potentiation or pharmacological intervention, whereas decrease of the ASR can be caused by habituation, PPI or again pharmacological intervention (Koch, 1999). Compounds affecting the glutamatergic NMDA pathways or dopaminergic pathways are commonly used deficit models in gating research (Kehne et al., 1991; Klamer et al., 2004). 


\subsection{PDE inhibitors and sensory gating}

Table 4. Overview studies sensory gating and PDE inhibition.

\begin{tabular}{|c|c|c|c|c|c|}
\hline Task & Model (species) & Treatment & Results & Recording site & Reference \\
\hline $\begin{array}{l}\text { Sensory } \\
\text { gating }\end{array}$ & Healthy (rats) & $\begin{array}{l}\text { PDE2-I: BAY } \\
60-7550 \text { (1.0 } \\
\mathrm{mg} / \mathrm{kg}, \text { p.o.) } \\
\text { and PDE5-I: } \\
\text { vardenafil } \\
\text { (1.0 mg/kg, } \\
\text { p.o.) and } \\
\text { PDE10-I: PQ- } \\
10 \text { (1.0 } \\
\mathrm{mg} / \mathrm{kg}, \text { p.o.) }\end{array}$ & $\begin{array}{l}\text { Administration } \\
\text { of PDE-Is did } \\
\text { not affect } \\
\text { sensory gating }\end{array}$ & $\begin{array}{l}\text { Striatum, } \\
\text { dorsal } \\
\text { hippocampus } \\
\text { and vertex }\end{array}$ & $\begin{array}{l}\text { Reneerkens } \\
\text { et al., 2013B }\end{array}$ \\
\hline $\begin{array}{l}\text { Sensory } \\
\text { gating }\end{array}$ & $\begin{array}{l}\text { Impaired (DBA2 } \\
\text { mice) }\end{array}$ & $\begin{array}{l}\text { PDE2-I: Lu } \\
\text { AF64280 (5.0 } \\
\text { and } 20.0 \\
\mathrm{mg} / \mathrm{kg} \text {, s.c.) }\end{array}$ & $\begin{array}{l}\text { Lu AF64280 } \\
20.0 \mathrm{mg} / \mathrm{kg} \\
\text { reduced the T/C } \\
\text { ratio }\end{array}$ & $\begin{array}{l}\text { CA3 region } \\
\text { hippocampus }\end{array}$ & $\begin{array}{l}\text { Redrobe et } \\
\text { al., } 2014\end{array}$ \\
\hline $\begin{array}{l}\text { Sensory } \\
\text { gating }\end{array}$ & $\begin{array}{l}\text { Healthy (mice) } \\
\text { and } \\
\text { amphetamine- } \\
\text { induced deficit } \\
\text { (5.0 } \mathrm{mg} / \mathrm{kg} \text {, } \\
\text { i.p.)(mice) }\end{array}$ & $\begin{array}{l}\text { PDE4-I: } \\
\text { Rolipram (0.1, } \\
1.0 \text { and } 2.0 \\
\mathrm{mg} / \mathrm{kg}, \text { i.p.) }\end{array}$ & $\begin{array}{l}\text { Rolipram alone } \\
\text { dose } \\
\text { dependently } \\
\text { enhances the } \\
\text { amplitude of } \\
\text { the first } \\
\text { stimulus on } \\
\text { the P20, N40 } \\
\text { and P20N40 } \\
\text { components. } \\
\text { Additionally, } \\
\text { rolipram } \\
\text { normalizes } \\
\text { the } \\
\text { amphetamine- } \\
\text { induced } \\
\text { amplitude } \\
\text { decrease } \\
\text { on the first } \\
\text { stimulus on } \\
\text { each } \\
\text { component }\end{array}$ & Hippocampus & $\begin{array}{l}\text { Maxwell et } \\
\text { al., } 2004\end{array}$ \\
\hline $\begin{array}{l}\text { Sensory } \\
\text { gating }\end{array}$ & $\begin{array}{l}\text { Healthy (mice) } \\
\text { and } \\
\text { amphetamine- } \\
\text { induced deficit } \\
\text { model ( } 0.5 \\
\mathrm{mg} / \mathrm{kg}, \mathrm{n.p.} \text {.) }\end{array}$ & $\begin{array}{l}\text { PDE4-I: RO- } \\
20-1724 \text { (0.1, } \\
0.25,0.5,1.0, \\
\text { and } 2.5 \\
\mathrm{mg} / \mathrm{kg}, \text { s.c.) }\end{array}$ & $\begin{array}{l}\text { RO-20-1724 } \\
0.25,0.5, \text { and } \\
1.0 \mathrm{mg} / \mathrm{kg} \\
\text { increased the } \\
\text { amplitude of } \\
\text { the P20 } \\
\text { component of }\end{array}$ & $\begin{array}{l}\text { CA3 region } \\
\text { hippocampus }\end{array}$ & $\begin{array}{l}\text { Halene and } \\
\text { Siegel, } 2008\end{array}$ \\
\hline
\end{tabular}




\begin{tabular}{|c|c|c|c|c|c|}
\hline & & & $\begin{array}{l}\text { the first click } \\
\text { and increased } \\
\text { the N40 } \\
\text { amplitude. RO- } \\
20-17240.25 \\
\mathrm{mg} / \mathrm{kg} \text { restored } \\
\text { gating and } \\
\text { increased S1 } \\
\text { amplitude } \\
\text { compared to } \\
\text { amphetamine } \\
\text { alone }\end{array}$ & & \\
\hline $\begin{array}{l}\text { Sensory } \\
\text { gating }\end{array}$ & $\begin{array}{l}\text { Healthy (rats) } \\
\text { and healthy } \\
\text { (human) }\end{array}$ & $\begin{array}{l}\text { Rat: PDE5-I: } \\
\text { vardenafil } \\
(0.3,1.0 \text { and } \\
3.0 \mathrm{mg} / \mathrm{kg} \text {, } \\
\text { p.o.), human: } \\
\text { vardenafil } \\
(10.0 \text { and } \\
20.0 \mathrm{mg} \text {, oral }\end{array}$ & $\begin{array}{l}\text { Administration } \\
\text { of vardenafil did } \\
\text { neither have an } \\
\text { effect on } \\
\text { sensory gating } \\
\text { in rats nor in } \\
\text { humans }\end{array}$ & $\begin{array}{l}\text { Rat: vertex, } \\
\text { hippocampus } \\
\text { and striatum, } \\
\text { human: cortex } \\
\text { (Fz, Fcz and Cz } \\
\text { electrodes) }\end{array}$ & $\begin{array}{l}\text { Reneerkens } \\
\text { et al., 2013A }\end{array}$ \\
\hline $\begin{array}{l}\text { Sensory } \\
\text { gating }\end{array}$ & $\begin{array}{l}\text { Amphetamine- } \\
\text { induced deficit } \\
\text { model }(1 \mathrm{mg} / \mathrm{kg} \text {, } \\
\text { i.v.)(mice) }\end{array}$ & $\begin{array}{l}\text { PDE9-I: PF- } \\
4447943 \text { (0.1, } \\
0.32 \text { and } 1.0 \\
\mathrm{mg} / \mathrm{kg}, \text { s.c.) } \\
\text { and PF- } \\
4449613 \text { (1.0 } \\
\mathrm{mg} / \mathrm{kg}, \text { s.c.) }\end{array}$ & $\begin{array}{l}\text { PF-4447943 } 0.1 \\
\text { and } 0.32 \mathrm{mg} / \mathrm{kg} \\
\text { and PF- } 4449613 \\
1.0 \mathrm{mg} / \mathrm{kg} \\
\text { reversed } \\
\text { amphetamine- } \\
\text { induced deficit }\end{array}$ & $\begin{array}{l}\text { CA3 region left } \\
\text { hippocampus }\end{array}$ & $\begin{array}{l}\text { Kleiman et al., } \\
2012\end{array}$ \\
\hline $\begin{array}{l}\text { Sensory } \\
\text { gating }\end{array}$ & $\begin{array}{l}\text { Amphetamine- } \\
\text { induced deficit } \\
\text { model }(1 \mathrm{mg} / \mathrm{kg} \text {, } \\
\text { i.v.)(rats) }\end{array}$ & $\begin{array}{l}\text { PDE10-I: TP- } \\
10 \text { (3.0 } \\
\mathrm{mg} / \mathrm{kg}, \text { i.v. })\end{array}$ & $\begin{array}{l}\text { TP-10 reversed } \\
\text { gating deficit }\end{array}$ & $\begin{array}{l}\text { CA3 region left } \\
\text { hippocampus }\end{array}$ & $\begin{array}{l}\text { Schmidt et al., } \\
2008\end{array}$ \\
\hline
\end{tabular}

i.p. $=$ intra peritoneal; i.v. $=$ intra venous; s.c. $=$ subcutaneous; p.o. $=$ per os; n.p. $=$ not provided

\subsubsection{PDE2 inhibitors}

In a recent study the novel CAMP/CGMP-specific PDE2A-I Lu AF64280 significantly reduced the deficit in sensory gating of DBA2 mice (Redrobe, Jorgensen, Christoffersen, Montezinho, Bastlund, Carnerup, Bundgaard, Lerdrup, and Plath, 2014). Furthermore, Reneerkens and colleagues showed that the CAMP/cGMP-specific PDE2A-I BAY 60-7550 did not affect sensory gating in rats measured unilaterally in vertex or unilaterally in striatum or dorsal hippocampus (Reneerkens et al., 2013b). However, PDE2 inhibition increased the P1 peak after presentation of S1 at the vertex. PDE2 inhibition may thus affect auditory processing in general, yet not sensory gating. These two studies do not provide a clear picture as to the role of PDE 2 in auditory gating. The different models applied in both studies may underlie these different findings.

\subsubsection{PDE4 inhibitors}


Maxwell et al. (Maxwell et al., 2004) showed that the CAMP-specific PDE4-I studied the effects of rolipram in a model for impaired auditory processing in schizophrenia. They recorded local field potentials in rats with and without amphetamine. They found that rolipram dose dependently enhanced the amplitude of the first stimulus on the P20, N40 and P20-N40 components. In addition, rolipram was able to normalize the amphetamine-induced amplitude decrease on the first stimulus on each component. In another study applying the same model for schizophrenia, the PDE4-I RO-201724 increased the amplitude of the P20 and N40 ERP components at the cortex (Halene and Siegel, 2008). Like rolipram, this PDE4-I was also able to reverse the amphetamine-induced decrease in amplitudes of these ERP components. These data support the notion that PDE4-Is may be relevant for disturbances of sensory processing as observed in schizophrenia.

\subsubsection{PDE5 inhibitors}

Reneerkens and colleagues (Reneerkens et al., 2013b) demonstrated that the cGMP-specific PDE5-I vardenafil did not affect sensory gating (double-click paradigm) in the striatum, dorsal hippocampus and vertex of rats. Another study by the same group (Reneerkens, Sambeth, Ramaekers, Steinbusch, Blokland, and Prickaerts, 2013a) showed that the cGMP-specific PDE5-I vardenafil had no effect on auditory sensory gating (similar paradigm was used as in rats) in the vertex of humans. These data indicate that PDE5 is not involved in the early stages of auditory information processing.

\subsubsection{PDE9 inhibitors}

Recordings of field potentials from the hippocampal CA3 region of anesthetized rats were used to monitor auditory evoked potentials (AEPs) that demonstrated auditory gating. Rats were anesthetized with chloral hydrate. Anesthetized rats were placed in a stereotaxic frame and amphetamine was administered to disrupt sensory gating. Acute administration of the cGMP/CAMPspecific PDE9A-I PF-4447943 or PDE9A-I PF-4449613 reversed the amphetamine-induced deficit in auditory gating in anesthetized rats (Kleiman et al., 2012). Although this study was conducted in anesthetized animals, these data suggest that PDE9 could be regarded as a relevant target for improving auditory processing deficits in schizophrenia.

\subsubsection{PDE 10 inhibitors}

In 2008, field potentials were recorded from the CA3 region of the left hippocampus of SpragueDawley rats after administration of the cGMP/CAMP-specific PDE10A-I TP-10. TP-10 significantly reversed the gating deficit induced by amphetamine pre-treatment (Schmidt et al., 2008). Furthermore, Reneerkens and colleagues (Reneerkens et al., 2013b) showed that the PDE10-I PQ-10 did not affect sensory gating in rats as measured in the vertex and unilaterally in striatum and dorsal 
hippocampus. However, PQ-10 increased the N1 peak after presentation of S1 as compared to vehicle treatment at the hippocampus. PDE10 inhibition may thus affect auditory processing in general but not sensory gating (see Table 4).

Inspection of the sensory gating data reveals a remarkable observation: PDE-Is exerting an effect in deficit models only. Experiments in healthy rats or humans show no effects of any type of PDE-I (see Table 4). Standard deficit model in sensory gating research is the amphetamine-induced deficit model. Amphetamine is known to enhance, among others, the levels of catecholamines in the brain. Catecholamines are thought to play an important role in sensory gating. Studies with unimpaired participants showed that decreasing levels of catecholamines decrease sensory gating (Braff and Huey, 1988). Studies with animals showed the same effects of catecholamines on sensory gating, both at the behavioral level and the neuronal level (Swerdlow et al., 1986). Other deficit models are the MK-801-induced, apomorphine- and quinpirole-induced deficit models.

\subsection{PDE inhibitors and sensorimotor gating}

As mentioned earlier, sensorimotor gating is measured via PPI. PPI is a neurological phenomenon in which a weaker prestimulus (prepulse) inhibits the reaction of the animal to a subsequent strong startling stimulus (pulse). The stimuli are usually acoustic, but tactile stimuli (e.g. via air puffs onto the skin) and light stimuli are also used. The reduction of the amplitude of the startle reflects the ability of the nervous system to temporarily adapt to a strong sensory stimulus when a preceding weaker signal is given to warn the organism. PPI is detected in numerous species ranging from mice to humans.

Although the extent of the adaptation affects numerous systems, the most comfortable to measure are the muscular reactions, which are normally diminished as a result of the nervous inhibition. Effects of PDE-Is on sensorimotor gating are most likely induced via enhanced signaling in the startle response circuitry (i.e. cochlear nuclei, caudal pontine reticular nucleus (PnC) and motor neurons)(Koch, 1999). The brain mechanisms underlying the mediation of PPI are still not fully understood, though, the attenuating effect on the ASR of acoustic prepulses probably affects the primary ASR pathway at the level of the PnC (Carlson and Willott, 1998; Lingenhohl and Friauf, 1994; Willott et al., 1994; Wu et al., 1988) most likely by activation of an inhibitory cholinergic (muscarinic) projection from the pedunculopontine tegmental nucleus (PPTg) to the PnC (Koch et al., 1993; Swerdlow and Geyer, 1993). Lesions of the inferior colliculi disrupt PPI by auditory prepulses (Leitner and Cohen, 1985; Li et al., 1998) suggesting that the ascending auditory pathway activates the PPI circuit at the level of the midbrain. 
Table 5. Overview studies sensorimotor gating and PDE inhibition.

\begin{tabular}{|c|c|c|c|c|}
\hline Task & Model (species) & Treatment & Results & Reference \\
\hline $\begin{array}{l}\text { Prepulse } \\
\text { inhibition }\end{array}$ & Unknown & $\begin{array}{l}\text { PDE1-I: name } \\
\text { unknown }\end{array}$ & $\begin{array}{l}\text { Compound did } \\
\text { not alter prepulse } \\
\text { inhibition }\end{array}$ & Zhang et al., 2010 \\
\hline $\begin{array}{l}\text { Prepulse } \\
\text { inhibition }\end{array}$ & $\begin{array}{l}\text { DARPP-32 } \\
\text { knockout } \\
\text { and wildtype } \\
\text { (mice) }\end{array}$ & $\begin{array}{l}\text { PDE4-I: Rolipram } \\
\text { ( } 3.0 \text { and } 10.0 \\
\mathrm{mg} / \mathrm{kg} \text {, i.p.) }\end{array}$ & $\begin{array}{l}\text { Both doses } \\
\text { increased } \\
\text { prepulse } \\
\text { inhibition in } \\
\text { wildtype mice but } \\
\text { failed to do so in } \\
\text { DARPP-32 } \\
\text { knockout mice }\end{array}$ & $\begin{array}{l}\text { Kuroiwa et al., } \\
2012\end{array}$ \\
\hline $\begin{array}{l}\text { Prepulse } \\
\text { inhibition }\end{array}$ & Unimpaired (rats) & $\begin{array}{l}\text { PDE4-I: Rolipram } \\
\text { (0.05 - } 10.0 \\
\mathrm{mg} / \mathrm{kg} \text {, i.p.) }\end{array}$ & $\begin{array}{l}\text { Rolipram } \\
\text { produced a rapid } \\
\text { and dose-related } \\
\text { increase in the } \\
\text { amplitude of the } \\
\text { acoustic startle } \\
\text { response. }\end{array}$ & $\begin{array}{l}\text { Kehne, Boulis and } \\
\text { Davis, } 1991\end{array}$ \\
\hline $\begin{array}{l}\text { Prepulse } \\
\text { inhibition }\end{array}$ & $\begin{array}{l}\text { Impaired } \\
\text { (C57BL/6J mice) } \\
\text { and } \\
\text { amphetamine- } \\
\text { induced deficit } \\
\text { model (10.0 } \\
\mathrm{mg} / \mathrm{kg} \text {, i.p.)(mice) }\end{array}$ & $\begin{array}{l}\text { PDE4-I: Rolipram } \\
(0.1,0.66,1.0 \text { and } \\
10.0 \mathrm{mg} / \mathrm{kg}, \text { i.p. })\end{array}$ & $\begin{array}{l}0.66,1.0 \text { and } 10.0 \\
\mathrm{mg} / \mathrm{kg} \text { rolipram } \\
\text { increased PPI and } \\
0.66 \mathrm{mg} / \mathrm{kg} \\
\text { rolipram blocked } \\
\text { disruptive effects } \\
\text { of amphetamine }\end{array}$ & Kanes et al., 2007 \\
\hline $\begin{array}{l}\text { Prepulse } \\
\text { inhibition }\end{array}$ & $\begin{array}{l}\text { Two } \\
\text { independently } \\
\text { derived ENU- } \\
\text { induced } \\
\text { mutations in Exon } \\
2 \text { of Disc1 (mice) }\end{array}$ & $\begin{array}{l}\text { PDE4-I: Rolipram } \\
\text { (0.5 mg/kg, i.p.) }\end{array}$ & $\begin{array}{l}\text { Rolipram } \\
\text { increased the PPI } \\
\text { of } 100 \mathrm{P} / 100 \mathrm{P} \text { and } \\
100 \mathrm{P} /+ \text { mice to } \\
\text { the level of }+/+ \\
\text { mice but did not } \\
\text { reverse the } \\
\text { milder PPI deficit } \\
\text { of } 31 \mathrm{~L} / 31 \mathrm{~L} \text { mice }\end{array}$ & $\begin{array}{l}\text { Clapcote et al., } \\
2007\end{array}$ \\
\hline $\begin{array}{l}\text { Prepulse } \\
\text { inhibition }\end{array}$ & $\begin{array}{l}\text { Amphetamine- } \\
\text { induced deficit } \\
\text { model (5.0 } \\
\mathrm{mg} / \mathrm{kg} \text {, } \\
\text { n.p.)(mice) }\end{array}$ & $\begin{array}{l}\text { PDE4-I: RO-20- } \\
1724(0.25,2.5 \text {, } \\
\text { and } 4.0 \mathrm{mg} / \mathrm{kg} \text {, } \\
\text { s.c.) }\end{array}$ & $\begin{array}{l}\text { No effects of any } \\
\text { dose on deficit in } \\
\text { prepulse } \\
\text { inhibition }\end{array}$ & $\begin{array}{l}\text { Halene and } \\
\text { Siegel, } 2008\end{array}$ \\
\hline $\begin{array}{l}\text { Prepulse } \\
\text { inhibition }\end{array}$ & $\begin{array}{l}\text { PDE4B knockout } \\
\text { (mice) }\end{array}$ & No treatment & $\begin{array}{l}\text { Knockout mice } \\
\text { showed a } \\
\text { reduction in } \\
\text { prepulse } \\
\text { inhibition }\end{array}$ & $\begin{array}{l}\text { Siuciak et al., } \\
2008\end{array}$ \\
\hline $\begin{array}{l}\text { Prepulse } \\
\text { inhibition }\end{array}$ & $\begin{array}{l}\text { Amphetamine- } \\
\text { induced deficit } \\
\text { model ( } 5 \mathrm{mg} / \mathrm{kg} \text {, } \\
\text { i.p.) and MK-801- }\end{array}$ & $\begin{array}{l}\text { PDE7-I: VP1.15 } \\
\text { (3.0 mg/kg, i.p.) }\end{array}$ & $\begin{array}{l}\text { VP1.15 reversed } \\
\text { only } \\
\text { amphetamine- } \\
\text { induced deficit }\end{array}$ & Lipina et al., 2013 \\
\hline
\end{tabular}




\begin{tabular}{|c|c|c|c|c|}
\hline & $\begin{array}{l}\text { induced deficit } \\
\text { model ( } 0.3 \\
\mathrm{mg} / \mathrm{kg} \text {, i.p.)(mice) }\end{array}$ & & $\begin{array}{l}\text { (not MK-801- } \\
\text { induced deficit) }\end{array}$ & \\
\hline $\begin{array}{l}\text { Prepulse } \\
\text { inhibition }\end{array}$ & $\begin{array}{l}\text { Impaired } \\
\text { (C57BL/6J mice) } \\
\text { and MK-801- } \\
\text { induced deficit } \\
\text { model (0.178 } \\
\mathrm{mg} / \mathrm{kg} \text {, s.c.)(mice) }\end{array}$ & $\begin{array}{l}\text { PDE9-I: PF- } \\
4447943(1.0,3.2, \\
10.0 \text { and } 32.0 \\
\mathrm{mg} / \mathrm{kg} \text {, s.c.) }\end{array}$ & $\begin{array}{l}\text { No effect in both } \\
\text { models }\end{array}$ & $\begin{array}{l}\text { Kleiman et al., } \\
2012\end{array}$ \\
\hline $\begin{array}{l}\text { Prepulse } \\
\text { inhibition }\end{array}$ & $\begin{array}{l}\text { Impaired } \\
\text { (C57BL/6J mice) } \\
\text { and MK-801- } \\
\text { induced deficit } \\
\text { model (0.178 } \\
\mathrm{mg} / \mathrm{kg} \text {, s.c.)(CD-1 } \\
\text { mice) }\end{array}$ & $\begin{array}{l}\text { PDE10-I: TP-10 } \\
(0.32,1.0,3.2 \text { and } \\
10 \mathrm{mg} / \mathrm{kg}, \mathrm{s.c} .) \\
\text { and TP-10 (1.0, } \\
3.2 \text { and } 10 \mathrm{mg} / \mathrm{kg} \text {, } \\
\text { s.c.) }\end{array}$ & $\begin{array}{l}\text { No effects of any } \\
\text { dose in both } \\
\text { models }\end{array}$ & $\begin{array}{l}\text { Schmidt et al., } \\
2008\end{array}$ \\
\hline $\begin{array}{l}\text { Prepulse } \\
\text { inhibition }\end{array}$ & $\begin{array}{l}\text { MK-801-induced } \\
\text { deficit model } \\
(0.085 \mathrm{mg} / \mathrm{kg} \text {, } \\
\text { s.c.)(rat) and } \\
\text { impaired } \\
\text { (C57BL/6J mice) }\end{array}$ & $\begin{array}{l}\text { PDE10-I: } \\
\text { Papaverine (Rat) } \\
\text { (3.0, } 10.0 \text { and } \\
30.0 \mathrm{mg} / \mathrm{kg}, \text { i.p.) } \\
\text { and } \mathrm{MP}-10 \text { (1.0, } \\
3.0 \text { and } 10.0 \\
\mathrm{mg} / \mathrm{kg}, \text { i.p.) } \\
\text { (mice) }(1.0,4.5 \text {, } \\
10.0,30.0 \text { and } \\
54.0 \mathrm{mg} / \mathrm{kg}, \text { i.p.) } \\
\text { and } \mathrm{MP}-10 \text { (1.0, } \\
3.0,10.0,30.0 \\
\text { and } 54.0 \mathrm{mg} / \mathrm{kg} \text {, } \\
\text { i.p.) }\end{array}$ & $\begin{array}{l}\text { Rat: } 10.0 \text { and } 30.0 \\
\mathrm{mg} / \mathrm{kg} \text { papaverine } \\
\text { and } 3.0 \text { and } 10.0 \\
\mathrm{mg} / \mathrm{kg} \mathrm{MP}-10 \\
\text { reversed deficit in } \\
\text { prepulse } \\
\text { inhibition } \\
\text { Mice: only } 54.0 \\
\mathrm{mg} / \mathrm{kg} \text { papaverine } \\
\text { and } 54.0 \mathrm{mg} / \mathrm{kg} \\
\text { MP-10 showed } \\
\text { greater prepulse } \\
\text { inhibition }\end{array}$ & $\begin{array}{l}\text { Grauer et al., } \\
2009\end{array}$ \\
\hline $\begin{array}{l}\text { Prepulse } \\
\text { inhibition }\end{array}$ & $\begin{array}{l}\text { Apomorphine- } \\
\text { induced deficit } \\
\text { model }(0.1 \text { and } \\
0.5 \mathrm{mg} / \mathrm{kg} \text {, s.c.) } \\
\text { and } \\
\text { amphetamine- } \\
\text { induced deficit } \\
\text { model }(4 \mathrm{mg} / \mathrm{kg} \text {, } \\
\text { s.c.)(rats) }\end{array}$ & $\begin{array}{l}\text { PDE10-I: } \\
\text { Papaverine (3.0, } \\
10.0 \text { and } 30.0 \\
\mathrm{mg} / \mathrm{kg} \text {, i.p.) }\end{array}$ & $\begin{array}{l}\text { Papaverine failed } \\
\text { to reverse } \\
\text { apomorphine- } \\
\text { and } \\
\text { amphetamine- } \\
\text { induced PPI } \\
\text { deficits at all } \\
\text { doses, strains, } \\
\text { pretreatment } \\
\text { times, and } \\
\text { prepulse intervals }\end{array}$ & $\begin{array}{l}\text { Weber et al., } \\
2009\end{array}$ \\
\hline $\begin{array}{l}\text { Prepulse } \\
\text { inhibition }\end{array}$ & $\begin{array}{l}\text { Apomorphine- } \\
\text { induced deficit } \\
\text { model ( } 0.5 \\
\mathrm{mg} / \mathrm{kg}, \mathrm{s.c} .) \text { and } \\
\text { quinpirole- } \\
\text { induced deficit } \\
\text { model (0.5 } \\
\mathrm{mg} / \mathrm{kg} \text {, s.c.)(rats) }\end{array}$ & $\begin{array}{l}\text { PDE10-I: TP-10 } \\
(0.32,1.0,3.2 \text { and } \\
10.0 \mathrm{mg} / \mathrm{kg}, \text { s.c. })\end{array}$ & $\begin{array}{l}\text { Only } 3.2 \mathrm{mg} / \mathrm{kg} \\
\text { TP-10 combined } \\
\text { with } \mathrm{SCH} 23390 \\
(0.005 \mathrm{mg} / \mathrm{kg} \text {, } \\
\text { s.c.) increased PPI } \\
\text { in apomorphine- } \\
\text { induced deficit } \\
\text { model }\end{array}$ & $\begin{array}{l}\text { Gresack et al., } \\
2013\end{array}$ \\
\hline $\begin{array}{l}\text { Acoustic startle } \\
\text { response }\end{array}$ & $\begin{array}{l}\text { Unimpaired } \\
\text { (larval zebrafish) }\end{array}$ & $\begin{array}{l}\text { PDE4-I: Rolipram } \\
(3.0,10.0 \text { and }\end{array}$ & $\begin{array}{l}\text { All doses } \\
\text { increased the }\end{array}$ & Best et al., 2008 \\
\hline
\end{tabular}




\begin{tabular}{|l|l|l|l|}
\hline & $30.0 \mu \mathrm{M})$ & $\begin{array}{l}\text { acoustic startle } \\
\text { response }\end{array}$ & \\
\hline
\end{tabular}

i.p. $=$ intra peritoneal, s.c. $=$ subcutaneous, n.p. $=$ not provided

\subsubsection{PDE1 inhibitors}

A novel and highly selective cGMP/CAMP-specific PDE1B-I has been developed by Intra-Cellular Therapies Inc (Zhang, 2010). Although the drug showed some anti-cataleptic potential in preclinical studies showed, this compound did not alter PPI or startle magnitude. It was suggested that this drug may work via DA D1 receptors, but at present no effects have been reported on sensorimotor gating.

\subsubsection{PDE4 inhibitors}

Systemic administration of the CAMP-specific PDE4-I rolipram produced a rapid and dose-related increase in the amplitude of the ASR in rats. The (-) isomer was more potent than the (+) isomer in enhancing startle amplitude. Rolipram increased startle responses that were elicited by brief electrical stimulation of the ventral cochlear nucleus or nucleus reticularis pontis caudalis, two brainstem relay nuclei of the startle neural circuit (Kehne et al., 1991). Rolipram also significantly increased PPI at doses that did not alter the acoustic startle response (lowest effective dose 0.66 $\mathrm{mg} / \mathrm{kg}$ ). In addition, rolipram blocked the disruptive effects of amphetamine on PPI (Kanes et al., 2007). Furthermore, rolipram increased the PPI of homozygous and heterozygous 100P mice (a mouse model for schizophrenia) to the level of wildtype mice but did not reverse the milder PPI deficit of heterozygous 31L mice (a mouse model for depression) (Clapcote et al., 2007). Additionally, rolipram did not affect startle responses to acoustic pulses at $120 \mathrm{~dB}$ in DARPP-32 knockout mice. DARPP-32 knockout mice naturally show a higher level of PPI compared to control mice. Rolipram did, however, decrease PPI in the control mice (Of note, DA D1 receptors signal through the CAMP/PKA/DARP-32 second messenger cascade, which is modulated by PDE4)(Kuroiwa et al., 2012). The study by Halene and Siegel (Halene and Siegel, 2008) used another PDE4-I: RO-20-1724. This compound did not significantly increase PPI in trials at any prepulse intensity for any tested dose in an amphetamine-induced deficit model. Further evidence is provided by PDE4B knockout mice that showed a significant reduction in PPI compared to wildtype mice (Siuciak et al., 2008). Finally, Best and colleagues (2008) demonstrated that zebrafish larvae (7 days post fertilization) exhibit iterative reduction in a startle response to a series of acoustic stimuli. Administration of rolipram increased the acoustic startle response in the zebrafish. Different models and drugs have been used to examine the effects of PDE4 inhibition on sensorimotor gating. In summary, these studies do not support a clear role of PDE4-I in sensorimotor gating paradigms (e.g., increase after rolipram, decrease in PDE4B knockout mice). The discrepancy in the effects between studies could be explained by the 
different test models that were used. Nevertheless, it seems that PDE4 is involved in sensorimotor gating processes.

\subsubsection{PDE7 inhibitors}

The dual inhibitor of PDE7 and GSK-3, named VP 1.15, facilitated PPI and reversed the amphetamineinduced PPI deficits. In contrast, VP 1.15 did not reverse the MK-801-induced PPI deficits (Lipina et al., 2013). This single study suggest that this PDE7-I may be gating processes but further studies need to show the specificity of these effects with respect to the underlying mechanism. Thus, it needs to be studied to what extend is this related to PDE7 or GSK-3, and how does this relates to a dopamine and glutamate.

\subsubsection{PDE9 inhibitors}

Administration of the cGMP-specific PDE9-I PF-4447943 had no effect on PPI in the poor-gating $\mathrm{C} 57 \mathrm{BL} / 6 \mathrm{~J}$ mice. However, the drug interacted with a sub threshold dose of risperidone $(0.32 \mathrm{mg} / \mathrm{kg})$ to significantly increase PPI at multiple doses. PF-4447943, however, was without effect on the disruption of PPI produced by the NMDA receptor antagonist MK-801 (Kleiman et al., 2012). These effects suggest a synergism between the effects of PF-4447943 and dopamine/serotonin, but not glutamate.

\subsubsection{PDE 10 inhibitors}

The cGMP/CAMP-specific PDE10A-I TP-10 was tested in two models by Schmidt and colleagues (Schmidt et al., 2008). In the first model (C57BL/6J mice), TP-10 had no effect at any dose at any of the prepulse intensities, nor did the compound reduce startle amplitude. In a second model, CD-1 mice were administered MK-801 before assessment of PPI. MK-801 significantly reduced PPI. Coadministration of TP-10 had no effect on the MK- 801-induced deficit. Another study tested TP-10 in different PPI experiments in combination with other dopaminergic drugs (Gresack et al., 2013). In line with the previous study, TP-10 had no significant effect on PPI alone, nor did it prevent the apomorphine-induced disruption of PPI. However, in a second experiment TP-10 treatment reversed the PPI impairment induced by quinpirole. In addition, the apomorphine-induced decrease in PPI was depended on the combined pretreatment of TP-10 with SCH23390. These effects cannot be attributed to TP-10 alone, as the TP-10/SCH23390 combination treated group also exhibited significantly higher PPI than the TP-10 alone group. Taken together these data suggest that PDE10-I by itself may not be very active in gating processes, but that there is a potential interaction with dopaminergic mechanisms. 
Two other CGMP/cAMP-specific PDE10A-Is, papaverine and MP-10, both blocked NMDA antagonistinduced deficits in PPI of acoustic startle response in rats, while improving baseline sensory gating in mice (Grauer et al., 2009). Furthermore, Weber and colleagues (Weber et al., 2009) showed that the CAMP/CGMP-selective PDE10A-I papaverine failed to reverse apomorphine- and amphetamineinduced PPI deficits at all doses, strains, pretreatment times, and prepulse intervals (see Table 5). In addition, a study using PDE10A knockout mice failed to report any effects on PPI (Piccart et al., 2014).

\subsection{Conclusion PDE inhibitors and gating}

Compared to the other two cognitive domains being discussed in this review, the cognitive concept of gating received most attention as a possible target for PDE-I treatment, mainly due to disruption of gating in several patients suffering from clinical disorders including schizophrenia and AD (e.g. Adler et al., 1982; Ally et al., 2006; Javitt, 2009; Jessen et al., 2001). All but one study were conducted in animals. Because it has been shown that the ERPs of humans and rats show a significant amount of similarities (e.g. Sambeth et al., 2003), we expect that the effects of drugs, like PDE-Is, on ERPs are translational between humans and animals (Maxwell et al., 2004).

The overall picture regarding PDE inhibition and gating is most promising for PDE4-Is, PDE10-Is appear interesting, while PDE1-Is, PDE2-Is and PDE5-Is may be least promising, although it has to be noted that research is scarce with the latter types of PDE-Is. Results are either negative (PDE1-Is and PDE2-Is) or mixed as in the case of PDE9-Is (Kleiman et al., 2012). PDE5-Is were tested in two studies, of which one study involving human participants. No effects are found at all for the potent inhibitor vardenafil, indicating that PDE5 is probably not involved in auditory gating in both rodents and humans.

Abundant evidence is provided for a role of the PDE4 subfamily in gating, although these data are almost exclusively based on the PDE4-I rolipram. In rats, mice and zebrafish positive effects are found of rolipram on gating. All studies, though, use different (deficit) models. ASRs were enhanced at a normal level, in an amphetamine-induced deficit model and in genetically modified animals. The latter model was used to investigate whether DARPP-32 is involved in the machinery by which rolipram might improve sensorimotor gating (Kuroiwa et al., 2012). DARPP-32 knockout mice showed a significantly higher level of PPI compared to control mice. Siuciak et al. (Siuciak et al., 2008) found that PDE4B knockout mice showed a significant reduction in PPI compared to wildtype mice indicating a role for PDE4B in auditory gating. Though, negative results were also found. Rolipram increased the PPI of 100P mice to the level of wild type mice but did not reverse the milder PPI deficit of $31 \mathrm{~L}$ mice (Clapcote et al., 2007). The only true negative results came from a study using the PDE4-I 
RO-20-1724. RO-20-1724 failed to reverse the amphetamine-induced deficit in PPI (Halene and Siegel, 2008). Though, RO-20-1724 did reverse the effects of d-amphetamine on the N40 component. The failure to reverse the amphetamine-induced deficit in PPI can most likely be attributed to the potency of the compound since rolipram did reverse PPI in an amphetamine-induced deficit model. In summary, it appears that PDE4-Is are most promising to improve sensory gating as well as sensorimotor gating.

PDE10-Is were investigated in five studies involving rats and mice. Schmidt et al. (Schmidt et al., 2008) showed that the PDE10-I TP-10 reversed sensory gating deficits in the hippocampus induced by d-amphetamine but found no effects in an MK-801 deficit model of PPI. Findings from Gresack et al. (Gresack et al., 2013) are in line with the previous study showing, again, no effects of TP-10 on PPI or only an effect when combined with a D1 antagonist. Thirdly, Piccart et al. (2014) also found no effects on PPI in PDE10A -/- deficient mice. In contrast, Grauer et al. (Grauer et al., 2009) significantly reduced the MK-801 deficit in PPI with both papaverine and MP-10. Though, the former study was performed in anesthetized rats while the latter used freely moving rats in Plexiglas cylinders as testing chambers. Additionally, the routes of administration differed between studies (i.p. versus s.c.), which might be of influence. In contrast to Grauer et al., a study by Weber et al. (2009) found no effects of papaverine on PPI in both an apomorphine- and amphetamine-induced deficit model. In conclusion, no definitive judgments can be made about PDE10A-Is as results within both sensory gating and sensorimotor gating are contradictory. The only tentative conclusion may be that the PDE10A-I TP-10 does not affect PPI per se since this is the only consistent finding.

PDE-Is improving in particular sensory gating act by targeting PDEs expressed in the neurons of the thalamic "gate", in the frontal inhibitory output neurons or in the neurons that locally release inhibitory neurotransmitter. In addition, many modulatory neuronal connections could also play a role and PDEs in these modulatory brain areas and neurons can thus exert an effect on sensory gating. PDE4-Is, PDE9-Is and PDE10-Is all showed positive effects in animals and they are expressed relatively high in the thalamus. Yet, how expression patterns of PDEs look like in the other brain areas is unknown and making predictions about how all the modulatory mechanisms might lead to an overall effect is almost impossible without further fundamental knowledge of PDE expression patterns.

For sensorimotor gating the story seems even more complex. Further detailed knowledge about the expression patterns in the startle response circuitry is essential. Since the attenuating effects on the ASR of acoustic prepulses are most likely induced at the level of the PnC, this might be an 
appropriate starting point for future studies, though other areas of the circuitry may be equally suited. Since detailed knowledge on expression patterns is currently lacking, no predictions from a neurobiological standpoint can yet be made. Derived from experimental results, only PDE4-Is seem to provide constant positive outcomes and can currently be viewed as the most promising PDE-I subtype for enhancement in the cognitive domain of sensorimotor gating.

\section{Drug-induced hyper locomotion}

\section{1 (Hyper) locomotion and biology}

Locomotion is a complex behavior that results from neural activation in the cerebral cortex, basal ganglia, cerebellum, brainstem locomotor regions and central pattern generators in the spinal cord. While different neurochemical mechanisms are involved in this neural activation, DA appears to play an essential role (Le Moal and Simon, 1991; Salamone et al., 2005). Pharmacological blockade of DA transmission inhibits spontaneous locomotion and greatly attenuates behavioral activation, independent of its triggering mechanisms (Kiyatkin, 2002). On the other hand, various environmental challenges that induce locomotor activation also increase DA transmission and vice versa as hyperlocomotion and stereotypy also occur during pharmacological increase in DA transmission induced by both direct (i.e. bromocriptine, apomorphine) and indirect (i.e. amphetamine, methamphetamine, cocaine) DA agonists.

Interestingly, all substances inducing hyperlocomotion also induce increased motor impulsivity (Bickel et al., 2012; Dalley et al., 2011; de Wit, 2009). Motor impulsivity in general, or response inhibition in particular, i.e. the ability to inhibit a prepotent response, is assumed to find its neurobiological origin in frontostriatal circuitry, as does (hyper)locomotion (Albrecht et al., 2014; Dalley et al., 2008; Feil et al., 2010; Trifilieff and Martinez, 2014). Disorders involving deficits in motor impulsivity may therefore benefit from PDE-Is in a manner similar to hyperlocomotion. Disturbances in motor impulsivity are characteristic of many neurodegenerative disorders such as $A D$ and Parkinson's disease (PD), psychiatric illness including schizophrenia, depression and obsessive compulsive disorder (OCD), as well as pervasive developmental disorders such as ADHD (Chudasama and Robbins, 2006) indicating a high medical need for these disorders.

In the current section we will first discuss the relation between PDE-Is and drug-induced hyperlocomotion. In the next section we will further illustrate response inhibition and motor impulsivity.

\subsection{PDE inhibitors and drug-induced hyperlocomotion}


Table 6. Overview studies hyperlocomotion and PDE inhibition.

\begin{tabular}{|c|c|c|c|c|}
\hline Task & Model (species) & Treatment & Results & Reference \\
\hline $\begin{array}{l}\text { Open field } \\
\text { test }\end{array}$ & $\begin{array}{l}\text { Ethanol-induced } \\
\text { hyperlocomotion (4 } \\
\text { times } 5 \mathrm{~g} / \mathrm{kg} \text {, } \\
\text { i.p.)(mice) }\end{array}$ & $\begin{array}{l}\text { PDE1: Vinpocetine (10.0 } \\
\text { and } 20.0 \mathrm{mg} / \mathrm{kg} \text {, i.p.) }\end{array}$ & $\begin{array}{l}\text { Vinpocetine } 20.0 \\
\mathrm{mg} / \mathrm{kg} \text { ameliorated } \\
\text { hyperactivity }\end{array}$ & $\begin{array}{l}\text { Nunes et al., } \\
2011\end{array}$ \\
\hline $\begin{array}{l}\text { Open field } \\
\text { test }\end{array}$ & $\begin{array}{l}\text { Methamphetamine- } \\
\text { induced } \\
\text { hyperlocomotion (5 } \\
\text { days } 4.0 \mathrm{mg} / \mathrm{kg} \\
\text { followed by } 2.0 \\
\mathrm{mg} / \mathrm{kg} \text { challenge } \\
\text { after } 1 \text {-week } \\
\text { withdrawal, } \\
\text { i.p.)(rats) }\end{array}$ & $\begin{array}{l}\text { PDE4: Rolipram (5 days } \\
4 \mathrm{mg} / \mathrm{kg} \text {, i.p.) }\end{array}$ & $\begin{array}{l}\text { Rolipram prevented } \\
\text { methamphetamine- } \\
\text { induced behavioral } \\
\text { sensitization }\end{array}$ & $\begin{array}{l}\text { lyo et al., } \\
1996\end{array}$ \\
\hline $\begin{array}{l}\text { Open field } \\
\text { test }\end{array}$ & $\begin{array}{l}\text { Methamphetamine- } \\
\text { induced } \\
\text { hyperlocomotion } \\
\text { ( } 1.0 \text { and } 2.0 \mathrm{mg} / \mathrm{kg} \text {, } \\
\text { s.c.), PCP-induced } \\
\text { hyperlocomotion } \\
\text { ( } 2.5 \text { and } 5.0 \mathrm{mg} / \mathrm{kg} \text {, } \\
\text { s.c.) and morphine- } \\
\text { induced } \\
\text { hyperlocomotion } \\
\text { ( } 20.0 \mathrm{mg} / \mathrm{kg} \text {, } \\
\text { s.c.)(mice) }\end{array}$ & $\begin{array}{l}\text { PDE4: Rolipram (1.0, } 3.2 \\
\text { and } 10.0 \mathrm{mg} / \mathrm{kg} \text {, i.p.) }\end{array}$ & $\begin{array}{l}\text { Rolipram } \\
\text { suppressed } \\
\text { methamphetamine- } \\
\text { induced } \\
\text { hyperlocomotion at } \\
\text { all doses, } \\
\text { morphine-induced } \\
\text { hyperlocomotion at } \\
3.2 \text { and } 10.0 \mathrm{mg} / \mathrm{kg} \\
\text { and had no effect } \\
\text { on PCP-induced } \\
\text { hyperlocomotion }\end{array}$ & $\begin{array}{l}\text { Mori et al., } \\
2000\end{array}$ \\
\hline $\begin{array}{l}\text { Open field } \\
\text { test }\end{array}$ & $\begin{array}{l}\text { Amphetamine- } \\
\text { induced } \\
\text { hyperlocomotion } \\
\text { (0.5 mg/kg, } \\
\text { s.c.)(rats) }\end{array}$ & $\begin{array}{l}\text { PDE10: MP-10 (0.08 - } \\
20.0 \mathrm{mg} / \mathrm{kg}, \text { p.o.) }\end{array}$ & $\begin{array}{l}\text { MP-10 } 5.0 \text { and } 20.0 \\
\mathrm{mg} / \mathrm{kg} \text { inhibited } \\
\text { amphetamine- } \\
\text { induced locomotor } \\
\text { hyperactivity }\end{array}$ & $\begin{array}{l}\text { Sotty et al., } \\
2009\end{array}$ \\
\hline $\begin{array}{l}\text { Open field } \\
\text { test }\end{array}$ & $\begin{array}{l}\text { PCP-induced } \\
\text { hyperlocomotion } \\
\text { (dose n.p., } \\
\text { i.p)(mice) }\end{array}$ & $\begin{array}{l}\text { PDE10: Compound } 56 \\
\text { ( } 20 \mathrm{mg} / \mathrm{kg} \text {, i.p.) }\end{array}$ & $\begin{array}{l}\text { Compound } 56 \\
\text { reduced } \\
\text { hyperactivity }\end{array}$ & $\begin{array}{l}\text { Gage et al., } \\
2011\end{array}$ \\
\hline $\begin{array}{l}\text { Open field } \\
\text { test }\end{array}$ & $\begin{array}{l}\text { MK-801-induced } \\
\text { hyperlocomotion } \\
(0.1 \mathrm{mg} / \mathrm{kg} \text {, } \\
\text { i.p.)(rats) }\end{array}$ & $\begin{array}{l}\text { PDE10: Compound } 66 \\
(0.1 \mathrm{mg} / \mathrm{kg}, \text { p.o.) }\end{array}$ & $\begin{array}{l}\text { Compound } 66 \\
\text { reversed MK-801- } \\
\text { induced } \\
\text { hyperactivity }\end{array}$ & $\begin{array}{l}\text { Malamas et } \\
\text { al., } 2012\end{array}$ \\
\hline $\begin{array}{l}\text { Open field } \\
\text { test }\end{array}$ & $\begin{array}{l}\text { PCP-induced } \\
\text { hyperlocomotion } \\
\text { (no further } \\
\text { information } \\
\text { provided)(mice) }\end{array}$ & $\begin{array}{l}\text { PDE10: Compound } 55 \text { (5 } \\
\mathrm{mg} / \mathrm{kg} \text {, p.o.) and } \\
\text { compound } 61 \text { ( } 4 \mathrm{mg} / \mathrm{kg} \text {, } \\
\text { p.o.) }\end{array}$ & $\begin{array}{l}\text { Both compounds } \\
\text { reduced PCP- } \\
\text { induced } \\
\text { hyperlocomotion }\end{array}$ & $\begin{array}{l}\text { Cutshall et } \\
\text { al., } 2012\end{array}$ \\
\hline $\begin{array}{l}\text { Open field } \\
\text { test }\end{array}$ & $\begin{array}{l}\text { MK-801-induced } \\
\text { hyperlocomotion } \\
\text { (no further } \\
\text { information } \\
\text { provided)(rats) }\end{array}$ & $\begin{array}{l}\text { PDE10: THPP-1 (1.0, } 3.0 \\
\text { and } 10.0 \mathrm{mg} / \mathrm{kg}, \text { p.o.) }\end{array}$ & $\begin{array}{l}\text { THPP-1 } 3.0 \text { and } \\
10.0 \mathrm{mg} / \mathrm{kg} \\
\text { displayed full } \\
\text { attenuation of MK- } \\
\text { 801-induced }\end{array}$ & $\begin{array}{l}\text { Raheem et } \\
\text { al., } 2012\end{array}$ \\
\hline
\end{tabular}




\begin{tabular}{|c|c|c|c|c|}
\hline & & & hyperlocomotion & \\
\hline $\begin{array}{l}\text { Activity } \\
\text { monitoring in } \\
\text { home cage }\end{array}$ & $\begin{array}{l}\text { Cocaine-induced } \\
\text { hyperactivity (15 } \\
\text { mg/kg, i.p.)(rats) }\end{array}$ & $\begin{array}{l}\text { Non-specific: } \\
\text { Isobutylmethylxanthine } \\
(\text { IBMX) }(0.1,1.0 \text { and } 2.0 \\
\mu \mathrm{g} / \mu \mathrm{L} \text {, i.c.v.) }\end{array}$ & $\begin{array}{l}\text { IBMX did not } \\
\text { attenuate increase } \\
\text { in activity }\end{array}$ & $\begin{array}{l}\text { Schroeder et } \\
\text { al., } 2012\end{array}$ \\
\hline $\begin{array}{l}\text { Locomotor } \\
\text { activity } \\
\text { assays }\end{array}$ & $\begin{array}{l}\text { Novelty-induced } \\
\text { locomotion, } \\
\text { amphetamine- } \\
\text { induced } \\
\text { hyperlocomotion } \\
\text { (1.25 } \mathrm{mg} / \mathrm{kg} \text {, s.c.), } \\
\text { scopolamine- } \\
\text { induced } \\
\text { hyperlocomotion } \\
\text { ( } 0.31 \mathrm{mg} / \mathrm{kg} \text {, } \\
\text { i.v.)and PCP- } \\
\text { induced } \\
\text { hyperlocomotion } \\
\text { (1.25 } \mathrm{mg} / \mathrm{kg}, \text { i.v.) } \\
\text { (rats) }\end{array}$ & $\begin{array}{l}\text { PDE10: JNJ-42314415, } \\
\text { TP-10, PQ-10 and MP-10 } \\
\text { (all compounds tested in } \\
\text { many dosages, s.c.) }\end{array}$ & $\begin{array}{l}\text { JNJ-42314415 } \\
(1.54,6.2,1.18, \\
1.54 \mathrm{mg} / \mathrm{kg} \text { were } \\
\text { minimal effective } \\
\text { dosages in the four } \\
\text { mentioned deficit } \\
\text { models in the left } \\
\text { column, } \\
\text { respectively), PQ- } \\
10(4.7,9.4,4.8,4.7 \\
\mathrm{mg} / \mathrm{kg}, \\
\text { respectively), TP-10 } \\
(0.77,4.1,0.78, \\
0.51 \mathrm{mg} / \mathrm{kg}, \\
\text { respectively) and } \\
\mathrm{MP}-10 \text { (0.44, 3.1, } \\
0.44,0.44 \mathrm{mg} / \mathrm{kg}, \\
\text { respectively) }\end{array}$ & $\begin{array}{l}\text { Megens et } \\
\text { al., } 2014\end{array}$ \\
\hline
\end{tabular}

i.m. $=$ intra muscular; i.p. $=$ intra peritoneal; i.v. $=$ intra venous; i.c.v. $=$ intra cerebrovascular; s.c. $=$ subcutaneous; p.o. $=$ per os

\subsubsection{PDE 1 inhibitors}

Early alcohol exposure significantly increased locomotor activity in the open field test, which has been linked to attention-deficit/hyperactivity disorder that can be observed in the fetal alcohol spectrum disorder (Nunes et al., 2011). In these animals a reduced cAMP level can be found in the hippocampus. The acute treatment of ethanol-exposed animals with the CAMP/cGMP-specific PDE1-I vinpocetine restored both their hyperlocomotor activity and CAMP levels to control levels (Nunes et al., 2011). These data suggest that hippocampal cAMP may underlie the hyperactivity and that this could be restored with a PDE1-I.

\subsubsection{PDE 4 inhibitors}

The administration of methamphetamine once a day for 5 days significantly enhanced hyperlocomotion and rearing induced by a $2-\mathrm{mg} / \mathrm{kg}$ methamphetamine challenge after a 1-week withdrawal period, compared with controls or coadministration with the CAMP-specific PDE4 inhibitor rolipram (lyo et al., 1996). Furthermore, the effects of rolipram on the hyperlocomotion induced by several abused drugs (methamphetamine, morphine and PCP) and a DA D1-receptor agonist (SKF81297) in mice were investigated. Methamphetamine, morphine, PCP and SKF81297 each induced dose-dependent hyperlocomotion. Rolipram suppressed methamphetamine and 
morphine-induced hyperlocomotion, but not PCP-induced hyperlocomotion. These results suggest that CAMP in the brain is involved in methamphetamine- and morphine-induced hyperlocomotion, while the underlying mechanism(s) of PCP-induced hyperlocomotion may be different from those of methamphetamine- and morphine-induced hyperlocomotion. It is well known that methamphetamine- and morphine-induced hyperlocomotion are mediated by the dopaminergic system and that interaction between postsynaptic D1- and D2-receptors may play an important role in the expression of various DA-mediated behaviors. SKF81297-induced hyperlocomotion was significantly but not completely suppressed by the highest dose of rolipram. Therefore, it is unlikely that postsynaptic D1-receptor-mediated functions are involved in the suppressive effects of rolipram on methamphetamine- and morphine-induced hyperlocomotion. These results suggest that rolipram may inhibit methamphetamine- and morphine-induced hyperlocomotion via increased cAMP levels at D2-receptors (Mori et al., 2000).

\subsubsection{PDE10 inhibitors}

The cGMP/cAMP-specific PDE10A inhibitor MP-10 blocked amphetamine-induced hyperlocomotion as well as amphetamine-induced DA efflux in the NAc in a dose-dependent manner (Sotty et al., 2009). Furthermore, the hydrazone-based cGMP/CAMP-specific PDE10A inhibitor compound 56 reduced PCP-induced hyperlocomotion in the search for novel treatment options in schizophrenia (Gage et al., 2011). Another hydrazone-based drug, called compound 55, also reduced PCP-induced hyperlocomotion in a separate study (Cutshall et al., 2012). The triazine-based PDE10A inhibitor compound 66 reversed MK-801 induced hyperlocomotion (Malamas et al., 2012). A fifth tetrahydropyridopyrimidine-based PDE10A inhibitor, THPP-1, displayed full attenuation of MK-801induced hyperlocomotion (Raheem et al., 2012). Lastly, the PDE10A-I JNJ-42314415 was tested for its effects on locomotion induced by novelty (normal locomotion), amphetamine, scopolamine and PCP (hyper-locomotion) (Megens et al., 2014). The compound was compared to other known PDE10A-Is (MP-10, PQ-10, TP-10) and DA D2 receptor blockers. All four PDE10A-Is used in the study reduced (hyper)locomotion induced by either novelty, amphetamine, scopolamine or PCP.

\subsubsection{Non-selective PDE inhibitors}

The non-selective PDE-I isobutylmethylxanthine (IBMX) did not affect the acute hyperlocomotor response to cocaine, but when coadministered with cocaine for 7 consecutive days, attenuated development of behavioral sensitization (Schroeder et al., 2012)(see Table 6).

\subsection{Conclusion PDE inhibitors and drug-induced hyperlocomotion}


It is well known that psychostimulants, i.e. amphetamine, methamphetamine, cocaine, as well as other drugs of abuse, i.e. alcohol, heroin, induce hyperlocomotion in rodents, which is believed to be mediated by dopaminergic, and especially the mesolimbic dopaminergic, system (Koob and Bloom, 1988; Nestler et al., 1996). There are two superfamilies of dopaminergic receptors, designated D1like and D2-like receptors (Sibley et al., 1993). D1-receptor agonists and D2-receptor agonists work synergistically in the expression of hyperlocomotion, stereotypies and rewarding effects. This may be indicative that the interaction between $\mathrm{D} 1$ and $\mathrm{D} 2$ receptors plays an important role in DA-mediated behaviors (Mori et al., 2000).

Administration of either drug discussed in the drug-induced hyperlocomotion section results in an increase in DA release in the mesolimbic and nigrostriatal DA pathways (Lobo and Nestler, 2011). Drug-induced increases in extracellular DA result in an up or down regulation of cAMP signaling in frontostriatal circuitry, depending on binding to D1 or D2 receptors in the direct or indirect pathway, respectively (Nishi et al., 2008; Nishi et al., 2011). Drugs of abuse thereby facilitate activity in the direct pathway and inhibit activity in the indirect pathway, both inducing excitation of the cortex and thus (extra) facilitation of movement (hyperlocomotion) (Lobo and Nestler, 2011). PDE10, to a less extent, PDE4 and, to an even lesser extent, PDE1, is expressed in both direct and indirect pathways with a preference for the latter (Nishi et al., 2008). PDE-Is of these subtypes therefore function mainly as DA D2 receptor antagonists (causing activation of the indirect pathway leading to less activation of the cortex and thus decreased movement) and function to a lesser extent as DA D1 receptor agonists (causing enhanced activation of the direct pathway leading to more activation of the cortex and increased movement). Because of the dominant expression of these PDEs in the indirect pathway, the activation of the indirect pathway offsets the activation of the direct pathway, inducing a net effect of less activation of the cortex, less activation of movement and thus counteraction of hyperlocomotion.

Though, cells are likely to be more sensitive to PDE inhibition at higher AC activity as the CAMP hydrolysis capacity is strained. Therefore, we propose that, for instance, PDE10A inhibition would exert a stronger effect on D1-expressing versus D2-expressing neurons in condition of increased dopaminergic transmission, since in this scenario, cAMP hydrolysis capacity is strained in D1expressing neurons. The effect on D2-expressing neurons would predominate in basal conditions, in line with findings of a study conducted in neostriatal slices (Nishi et al., 2008). In the end, this may sound like a competition of what gets there first. If effects of drugs of abuse are already present and of sufficient strength to strain CAMP hydrolysis, subsequent PDE inhibition will mainly affect cAMP in the direct pathway. Alternatively, if PDE-Is have started their effect before cAMP hydrolysis is 
strained via elevated DA levels through drugs of abuse, PDE inhibition will mainly affect CAMP in the indirect pathway. Though, PDE inhibition will also affect the release of DA presynaptically, either from substantia nigra (SN) or VTA. So even when DA is already being released after administration of drugs of abuse, the presynaptic effect of PDE inhibition can still shift the main postsynaptic effect from indirect to direct pathway. This could lead to an aggravation of drug-induced hyperlocomotion or shift the main postsynaptic effect from direct to indirect pathway leading to a reduction of druginduced hyperlocomotion.

\section{Miscellaneous}

Three studies could be added to the previous section, though, the output parameters of these tasks do not provide a clear indication of response inhibition, thus allowing ambiguity (see Table 7).

Table 7. Overview studies response inhibition, attention and PDE inhibition.

\begin{tabular}{|c|c|c|c|c|}
\hline Task & Model (species) & Treatment & Results & Reference \\
\hline $\begin{array}{l}\text { Object retrieval } \\
\text { task }\end{array}$ & $\begin{array}{l}\text { Unimpaired adult } \\
\text { (cynomolgus } \\
\text { macaques) }\end{array}$ & $\begin{array}{l}\text { PDE4: Rolipram (0.003- } \\
0.03 \mathrm{mg} / \mathrm{kg}, \text { i.m.) or } \\
\text { sildenafil }(0.3-3 \mathrm{mg} / \mathrm{kg} \text {, } \\
\text { i.m.) }\end{array}$ & $\begin{array}{l}\text { Rolipram (0.01 } \\
\mathrm{mg} / \mathrm{kg} \text { ) and } \\
\text { sildenafil (1 } \\
\mathrm{mg} / \mathrm{kg}) \\
\text { increased } \\
\text { correct first } \\
\text { reaches }\end{array}$ & $\begin{array}{l}\text { Rutten et al., } \\
2008\end{array}$ \\
\hline $\begin{array}{l}\text { Object retrieval } \\
\text { task }\end{array}$ & $\begin{array}{l}\text { Unimpaired adult } \\
\text { (cynomolgus } \\
\text { macaques) }\end{array}$ & $\begin{array}{l}\text { PDE4D: Rolipram (0.003- } \\
0.03 \mathrm{mg} / \mathrm{kg}, \text { i.m.) and } \\
\mathrm{D} 159687(0.05-5 \mathrm{mg} / \mathrm{kg}, \\
\text { p.o.) and D159797 (0.05- } \\
1 \mathrm{mg} / \mathrm{kg}, \text { p.o.)(negative } \\
\text { allosteric modulators) }\end{array}$ & $\begin{array}{l}\text { Rolipram (0.03), } \\
\text { D159687 (0.05- } \\
5 \mathrm{mg} / \mathrm{kg} \text { ) and } \\
\text { D159797 (0.5 } \\
\text { and } 1 \mathrm{mg} / \mathrm{kg}) \\
\text { increased } \\
\text { correct first } \\
\text { reaches }\end{array}$ & $\begin{array}{l}\text { Sutcliffe et al. } \\
2014\end{array}$ \\
\hline $\begin{array}{l}\text { Object retrieval } \\
\text { detour task }\end{array}$ & $\begin{array}{l}\text { Ketamine-induced } \\
\text { deficit model } \\
\text { (individual dosing, } \\
\text { i.m.)(rhesus } \\
\text { monkeys) }\end{array}$ & $\begin{array}{l}\text { PDE10: THPP-1 (3.0 and } \\
10.0 \mathrm{mg} / \mathrm{kg} \text {, day } 1-4 \text { p.o. } \\
\text { and day } 5 \text { oral) }\end{array}$ & $\begin{array}{l}\text { THPP-1 } 10.0 \\
\mathrm{mg} / \mathrm{kg} \\
\text { attenuated } \\
\text { impairment in } \\
\text { correct first } \\
\text { reaches }\end{array}$ & $\begin{array}{l}\text { Smith et al., } \\
2013\end{array}$ \\
\hline Stroop task & $\begin{array}{l}\text { Unimpaired } \\
\text { adults (human) }\end{array}$ & $\begin{array}{l}\text { PDE5: Vardenafil (10.0 } \\
\text { and } 20.0 \mathrm{mg} \text {, oral) }\end{array}$ & $\begin{array}{l}\text { No effects on } \\
\text { behavioral } \\
\text { measures, main } \\
\text { treatment } \\
\text { effect for P300 } \\
\text { on ERPs }\end{array}$ & $\begin{array}{l}\text { Reneerkens et } \\
\text { al., } 2013\end{array}$ \\
\hline
\end{tabular}

i.m. $=$ intra muscular; p.o. $=$ per os

\subsection{PDE 4 inhibitors}


In 2008 Rutten et al. (Rutten et al., 2008) showed that the CAMP-specific PDE4-I rolipram enhanced the percentage of correct first reaches (indicative of response inhibition and attention) in the object retrieval detour task (ORDT) in adult cynomolgus macaques. This improved performance was also found with a PDE4D negative allosteric modulator (Sutcliffe et al., 2014). Although these data strongly support a role of PDE4 in response inhibition, it should be noted that this task not only involves response inhibition but also involves cognitive functions.

\subsection{PDE 5 inhibitors}

In the same study by Rutten and colleagues (Rutten et al., 2008) the cGMP-specific PDE5-I sildenafil either enhanced the percentage of correct first reaches in the ORDT in adult cynomolgus macaques. So far, only one study involving human participants and including an impulsivity measure is known to us. (Reneerkens et al., 2013a) found no effect of the cGMP-specific PDE5 inhibitor vardenafil in the Stroop task, which is well known for its ability to induce interference, and assesses response inhibition and focused attention. These data do not suggest a role for PDE5 in response inhibition.

\subsection{PDE 10 inhibitors}

The cGMP/cAMP-specific PDE10A inhibitor THPP-1 has also been tested in the ORDT. However, the effects were tested in a ketamine deficit model, as a model of schizophrenia. THPP attenuated a ketamine-induced deficit in the ORDT in rhesus monkeys (Smith et al., 2013). The effects of THPP-1 alone were not tested in this study. These data may suggest a role for PDE10 in response inhibition, but may be limited to a ketamine-induced deficit.

\subsection{Conclusion miscellaneous}

The three studies discussed above are miscellaneous in the sense that the task used allows ambiguity as to what it actually measures. The main output parameter of the tasks measures both attention and response inhibition. With regard to the former subject they could be added to the attention section, with regard to the latter subject a new field of PDE research is addressed, though ambiguity allows neither. Response inhibition is part of the impulsivity taxonomy and can be assigned to the subdivision 'motor impulsivity' (Evenden, 1999).

As discussed previously, both PDE4 and PDE10A inhibition are expected to increase CAMP in both D1and D2-expressing striatal MSNs and thus in effect, potentiate the effect of D1 receptor activation and counteract the effect of D2 receptor activation as a result of their inverse coupling to AC. In this respect, PDE4 and PDE10 inhibition may, by facilitating D1 receptor-dependent excitatory effect and/or counteracting D2 receptor-dependent inhibitory effect of striatal MSNs activity, indirectly 
modulate feedback regulation of DA neuron activity thereby providing a reduction in drug-induced hyperlocomotion, with or without additional presynaptic effects (Nishi et al., 2008). Due to a larger expression of PDE10 in MSNs, compared to PDE4 (or PDE1), PDE10-Is are expected to be the most suitable tool for reducing drug-induced hyperlocomotion, which is in line with findings of previously discussed studies (Nishi et al., 2011).

Response inhibition is assumed to find its neurobiological origin in frontostriatal circuitry, as does locomotion (Albrecht et al., 2014; Dalley et al., 2008; Feil et al., 2010; Trifilieff and Martinez, 2014). Disorders involving deficits in motor impulsivity may therefore benefit from PDE-Is in the same way as does hyperlocomotion. This notion is reinforced by the fact that all substances in the drug-induced hyperlocomotion section also induce increased motor impulsivity (Bickel et al., 2012; Dalley et al., 2011; de Wit, 2009).

\section{General Discussion}

Besides the already known traditional PDE-Is such as sildenafil, more PDE-Is are now entering the stage of clinical research. However, in contrast to the large number of preclinical investigations, the number of clinical studies is limited since the PDE research field is still a relatively young field that really took a start in 1998 when Viagra (sildenafil) was approved by the American Food and Drug Administration (FDA) for treatment of erectile dysfunction. In the present review we focused on PDEIs as putative drugs for cognition enhancement beyond the memory domain focusing on the cognitive domains of attention, information filtering (sensory and sensorimotor gating) and response inhibition (drug-induced hyperlocomotion).

In summary, although the total number of studies is rather limited, most of the studies into the effects of PDE inhibition on attention, show improved performance on one of the many aspects of attention after PDE-I treatment. Because of the enormous extend of the attention network, stimulating intracellular signaling in a diverse range of brain structures could, theoretically, lead to enhanced performance on a behavioral task measuring one of the many aspects of attention. Several of these aspects of attention were measured by the studies discussed in this review, while investigating different types of PDE-Is. Therefore, only early conclusions can be drawn as to which (sub)type of PDE is the most promising target for enhancing attention performance. Most support for PDE-Is as possible attention enhancers is provided for PDE4 and PDE5 (see Table 8). Both subtypes are highly expressed in areas associated with Posner's attention network, especially PDE4 (Lakics et al., 2010). This may suggest that future studies should focus on these two PDEs using a wide variety of attention tasks to examine which aspects of attention are enhanced. Concluding, PDEs seem to be 
a promising target for enhancing attention and PDE4-Is and PDE5-Is seem to be the most promising tools, though subtype specificity should be further investigated.

Gating received more attention as a possible target for PDE-I treatment compared to the other cognitive domains. This is mainly because gating is disrupted in several patients suffering from clinical disorders including schizophrenia and AD (e.g. Adler et al., 1982; Ally et al., 2006; Javitt, 2009; Jessen et al., 2001). In the search for new and improved antipsychotics PDE-Is have been researched elaborately in sensory and sensorimotor gating paradigms. In both paradigms PDE4-Is have been most extensively investigated with rolipram exceeding all other PDE-Is. In conclusion, experiments in both paradigms all indicate PDEs, especially PDE4, to be considered as a promising target for improving gating (see Table 8). Rolipram showed positive results on gating in rats, mice and zebrafish; though no human trials have been conducted so far.

For drug-induced hyperlocomotion both PDE4-Is and PDE10-Is show best results (see Table 8) due to an expected potentiation of the effect of D1 receptor activation and counteraction of the effect of D2 receptor activation as a result of inverse coupling to AC. By facilitating the D1 receptor-dependent excitatory effect and/or counteracting the D2 receptor-dependent inhibitory effect of striatal MSNs, PDE-Is indirectly modulate feedback regulation of DA neuron activity thereby providing a reduction in drug-induced hyperlocomotion (Nishi et al., 2008). In conclusion, PDEs seem to be a promising target for counteracting drug-induced hyperlocomotion. Due to a larger expression of PDE10 in MSNs, compared to PDE4 (or PDE1), PDE10-Is are expected to be the most suitable tool for reducing druginduced hyperlocomotion.

Another cognitive domain in early information processing, that we have briefly touched upon in this review, is response inhibition (motor impulsivity). Since response inhibition and locomotion are both believed to find their origin in frontostriatal circuitry, disorders involving response inhibition, like ADHD and possibly addiction, might benefit from PDE-I treatment as does (drug-induced hyper)locomotion. Especially, since the drugs used to induce hyperlocomotion, all induce motor impulsivity as well (Bickel et al., 2012; Dalley et al., 2011; de Wit, 2009), likely via frontostriatal circuitry. Furthermore, the OR, measuring response inhibition in animals, also showed positive effects of PDE inhibition. These findings could not be replicated in humans using the Stroop task, although it should be mentioned that the tasks cannot be compared directly. Motor impulsivity might thus be a next promising cognitive domain benefitting from PDE-I treatment. 
Table 8. Overview of potential PDE-specific targets for improving cognitive functions: attention, information filtering (sensory and sensorimotor gating) and response inhibition (drug-induced hyperlocomotion).

\begin{tabular}{|l|l|}
\hline Cognitive domain & PDE type \\
\hline Attention & PDE4 and PDE5 \\
Sensory gating & PDE4, PDE9 and PDE10 \\
Sensorimotor gating & PDE4 \\
Response inhibition (motor impulsivity) & PDE4 and PDE10 \\
\hline
\end{tabular}

Though, several issues should be kept in mind when interpreting results thus far regarding all cognitive domains. First, it is important to know the exact localization and the level of expression of specific PDE enzymes in the normal brain. Secondly, it must be taken into account that the constitution of the brain changes with age and brain diseases and that this may affect the distribution and expression of PDEs in the brain. Thirdly, since most PDEs are transcribed by several genes, which give rise to multiple PDE splice variants and isoforms, further investigation into possible isoform-specific effects of PDE-Is is a field of great interest. Most PDE-Is currently available are selective for one particular PDE family. However, this implies that all PDE enzyme isoforms of that family will be inhibited. In case of PDE4 this implicates about 25 isoforms (Gurney et al., 2011), of which some can be associated with adverse side effects. This relates to a fourth point of consideration. It is clear that more selective PDE-Is are needed to have more specific biological activity without unwanted side effects. An example of this is the recent development of selective PDE4-Is for only one of the four PDE4 gene products. In particular nausea and emesis (vomiting) are linked to PDE4 inhibition. There are now PDE4D-Is which are devoid of emetic effects (Burgin et al., 2010) or have at least greatly reduced emetic effects (Bruno et al., 2011). Development of subtype specific PDE-Is has to be the next step. Increasing the selectivity of PDE-Is poses a major challenge which has to be achieved by influencing compound-enzyme interactions most likely outside the catalytic domain of the PDE enzymes (Gurney et al., 2011).

To summarize, PDEs seem to be a promising target in the field of cognition enhancement even beyond the memory domain. Although these new fields in PDE research are just emerging, clear positive effects have already been found in animals and, like in the memory domain, we are now awaiting translational confirmation by human data. Thus, providing further clinical proof of concept for cognition enhancing effects of PDE-Is and the generation of isoform selective PDE-Is are the final hurdles to overcome in developing safe and efficacious novel PDE-Is for the treatment of cognitive decline (also) beyond the memory domain. 


\section{Conflict of Interest}

There is no conflict of interest for the work being reported. 


\section{References}

Adler, L. E., Pachtman, E., Franks, R. D., Pecevich, M., Waldo, M. C., \& Freedman, R. (1982). Neurophysiological evidence for a defect in neuronal mechanisms involved in sensory gating in schizophrenia. Biol Psychiatry, 17, 639-654.

Albrecht, D. S., Kareken, D. A., Christian, B. T., Dzemidzic, M., \& Yoder, K. K. (2014). Cortical dopamine release during a behavioral response inhibition task. Synapse, 68, 266-274.

Ally, B. A., Jones, G. E., Cole, J. A., \& Budson, A. E. (2006). Sensory gating in patients with Alzheimer's disease and their biological children. Am J Alzheimers Dis Other Demen, 21, 439-447.

Arancio, O., Kandel, E. R., \& Hawkins, R. D. (1995). Activity-dependent long-term enhancement of transmitter release by presynaptic 3',5'-cyclic GMP in cultured hippocampal neurons. Nature, $376,74-80$.

Beavo, J. A. (1995). Cyclic nucleotide phosphodiesterases: functional implications of multiple isoforms. Physiol Rev, 75, 725-748.

Bender, A. T., \& Beavo, J. A. (2006). Cyclic nucleotide phosphodiesterases: molecular regulation to clinical use. Pharmacol Rev, 58, 488-520.

Berridge, C. W., Devilbiss, D. M., Andrzejewski, M. E., Arnsten, A. F. T., Kelley, A. E., Schmeichel, B., Hamilton, C., \& Spencer, R. C. (2006). Methylphenidate Preferentially Increases Catecholamine Neurotransmission within the Prefrontal Cortex at Low Doses that Enhance Cognitive Function. Biol Psychiat, 60, 1111-1120.

Best, J. D., Berghmans, S., Hunt, J. J., Clarke, S. C., Fleming, A., Goldsmith, P., \& Roach, A. G. (2008). Non-associative learning in larval zebrafish. Neuropsychopharmacology, 33, 1206-1215.

Bickel, W. K., Jarmolowicz, D. P., Mueller, E. T., Gatchalian, K. M., \& McClure, S. M. (2012). Are executive function and impulsivity antipodes? A conceptual reconstruction with special reference to addiction. Psychopharmacology (Berl), 221, 361-387.

Blaney, P. H. (1986). Affect and memory: a review. Psychol Bull, 99, 229-246.

Blokland, A., Menniti, F. S., \& Prickaerts, J. (2012). PDE inhibition and cognition enhancement. Expert Opin Ther Pat, 22, 349-354.

Bollen, E., \& Prickaerts, J. (2012). Phosphodiesterases in neurodegenerative disorders. IUBMB Life, 64, 965-970.

Bollen, E., Puzzo, D., Rutten, K., Privitera, L., De Vry, J., Vanmierlo, T., Kenis, G., Palmeri, A., D’Hooge, R., Balschun, D., Steinbusch, H., Blokland, A., \& Prickaerts, J. (2014). Improved Long-Term Memory via Enhancing CGMP-PKG Signaling Requires CAMP-PKA Signaling. Neuropsychopharmacology, 39, 2497-2505.

Boutros, N. N., Brockhaus-Dumke, A., Gjini, K., Vedeniapin, A., Elfakhani, M., Burroughs, S., \& Keshavan, M. (2009). Sensory-gating deficit of the N100 mid-latency auditory evoked potential in medicated schizophrenia patients. Schizophr Res, 113, 339-346.

Braff, D. L., \& Huey, L. (1988). Methylphenidate-induced information processing dysfunction in nonschizophrenic patients. Arch Gen Psychiatry, 45, 827-832.

Broberg, B. V., Oranje, B., Glenthoj, B. Y., Fejgin, K., Plath, N., \& Bastlund, J. F. (2010). Assessment of auditory sensory processing in a neurodevelopmental animal model of schizophrenia--gating of auditory-evoked potentials and prepulse inhibition. Behav Brain Res, 213, 142-147.

Bruno, O., Fedele, E., Prickaerts, J., Parker, L. A., Canepa, E., Brullo, C., Cavallero, A., Gardella, E., Balbi, A., Domenicotti, C., Bollen, E., Gijselaers, H. J., Vanmierlo, T., Erb, K., Limebeer, C. L., Argellati, F., Marinari, U. M., Pronzato, M. A., \& Ricciarelli, R. (2011). GEBR-7b, a novel PDE4D selective inhibitor that improves memory in rodents at non-emetic doses. $\mathrm{Br} J$ Pharmacol, 164, 2054-2063.

Burgin, A. B., Magnusson, O. T., Singh, J., Witte, P., Staker, B. L., Bjornsson, J. M., Thorsteinsdottir, M., Hrafnsdottir, S., Hagen, T., Kiselyov, A. S., Stewart, L. J., \& Gurney, M. E. (2010). Design of phosphodiesterase 4D (PDE4D) allosteric modulators for enhancing cognition with improved safety. Nat Biotechnol, 28, 63-70. 
Cahill, L., Prins, B., Weber, M., \& McGaugh, J. L. (1994). Beta-adrenergic activation and memory for emotional events. Nature, 371, 702-704.

Carlson, S., \& Willott, J. F. (1998). Caudal pontine reticular formation of C57BL/6J mice: responses to startle stimuli, inhibition by tones, and plasticity. J Neurophysiol, 79, 2603-2614.

Castellanos, F. X., Lee, P. P., Sharp, W., Jeffries, N. O., Greenstein, D. K., Clasen, L. S., Blumenthal, J. D., James, R. S., Ebens, C. L., Walter, J. M., Zijdenbos, A., Evans, A. C., Giedd, J. N., \& Rapoport, J. L. (2002). Developmental trajectories of brain volume abnormalities in children and adolescents with attention-deficit/hyperactivity disorder. JAMA, 288, 1740-1748.

Chang, W. P., Arfken, C. L., Sangal, M. P., \& Boutros, N. N. (2011). Probing the relative contribution of the first and second responses to sensory gating indices: a meta-analysis. Psychophysiology, 48, 980-992.

Chudasama, Y., \& Robbins, T. W. (2006). Functions of frontostriatal systems in cognition: comparative neuropsychopharmacological studies in rats, monkeys and humans. Biol Psychol, 73, 19-38.

Clapcote, S. J., Lipina, T. V., Millar, J. K., Mackie, S., Christie, S., Ogawa, F., Lerch, J. P., Trimble, K., Uchiyama, M., Sakuraba, Y., Kaneda, H., Shiroishi, T., Houslay, M. D., Henkelman, R. M., Sled, J. G., Gondo, Y., Porteous, D. J., \& Roder, J. C. (2007). Behavioral phenotypes of Disc1 missense mutations in mice. Neuron, 54, 387-402.

Cromwell, H. C., Mears, R. P., Wan, L., \& Boutros, N. N. (2008). Sensory gating: a translational effort from basic to clinical science. Clin EEG Neurosci, 39, 69-72.

Cutshall, N. S., Onrust, R., Rohde, A., Gragerov, S., Hamilton, L., Harbol, K., Shen, H. R., McKee, S., Zuta, C., Gragerova, G., Florio, V., Wheeler, T. N., \& Gage, J. L. (2012). Novel 2methoxyacylhydrazones as potent, selective PDE10A inhibitors with activity in animal models of schizophrenia. Bioorg Med Chem Lett, 22, 5595-5599.

Dalecki, A., Croft, R. J., \& Johnstone, S. J. (2011). An evaluation of P50 paired-click methodologies. Psychophysiology, 48, 1692-1700.

Dalley, J. W., Everitt, B. J., \& Robbins, T. W. (2011). Impulsivity, compulsivity, and top-down cognitive control. Neuron, 69, 680-694.

Dalley, J. W., Mar, A. C., Economidou, D., \& Robbins, T. W. (2008). Neurobehavioral mechanisms of impulsivity: fronto-striatal systems and functional neurochemistry. Pharmacol Biochem Behav, 90, 250-260.

Davis, H. P., \& Squire, L. R. (1984). Protein synthesis and memory: a review. Psychol Bull, 96, 518-559.

Davis, J. A., \& Gould, T. J. (2005). Rolipram Attenuates MK-801-Induced Deficits in Latent Inhibition. Behavioral Neuroscience, 119, 595-602.

de Bruin, N. M., Ellenbroek, B. A., van Schaijk, W. J., Cools, A. R., Coenen, A. M., \& van Luijtelaar, E. L. (2001). Sensory gating of auditory evoked potentials in rats: effects of repetitive stimulation and the interstimulus interval. Biol Psychol, 55, 195-213.

de Wit, H. (2009). Impulsivity as a determinant and consequence of drug use: a review of underlying processes. Addict Biol, 14, 22-31.

DeZazzo, J., \& Tully, T. (1995). Dissection of memory formation: from behavioral pharmacology to molecular genetics. Trends Neurosci, 18, 212-218.

Evenden, J. L. (1999). Varieties of impulsivity. Psychopharmacology (Berl), 146, 348-361.

Fan, J., \& Posner, M. (2004). Human attentional networks. Psychiatr Prax, 31 Suppl 2, S210-214.

Feil, J., Sheppard, D., Fitzgerald, P. B., Yucel, M., Lubman, D. I., \& Bradshaw, J. L. (2010). Addiction, compulsive drug seeking, and the role of frontostriatal mechanisms in regulating inhibitory control. Neurosci Biobehav Rev, 35, 248-275.

Folstein, M. F., \& Whitehouse, P. J. (1983). Cognitive impairment of Alzheimer disease. Neurobehav Toxicol Teratol, 5, 631-634.

Francis, S. H., Blount, M. A., \& Corbin, J. D. (2011). Mammalian cyclic nucleotide phosphodiesterases: molecular mechanisms and physiological functions. Physiol Rev, 91, 651-690.

Freedman, R., Waldo, M., Bickford-Wimer, P., \& Nagamoto, H. (1991). Elementary neuronal dysfunctions in schizophrenia. Schizophr Res, 4, 233-243. 
Frith, C. (1996). Neuropsychology of schizophrenia, what are the implications of intellectual and experiential abnormalities for the neurobiology of schizophrenia? Br Med Bull, 52, 618-626.

Gage, J. L., Onrust, R., Johnston, D., Osnowski, A., Macdonald, W., Mitchell, L., Urogdi, L., Rohde, A., Harbol, K., Gragerov, S., Dorman, G., Wheeler, T., Florio, V., \& Cutshall, N. S. (2011). NAcylhydrazones as inhibitors of PDE10A. Bioorg Med Chem Lett, 21, 4155-4159.

Grass, H., Klotz, T., Fathian-Sabet, B., Berghaus, G., Engelmann, U., \& Kaferstein, H. (2001). Sildenafil (Viagra): is there an influence on psychological performance? Int Urol Nephrol, 32, 409-412.

Grauer, S. M., Pulito, V. L., Navarra, R. L., Kelly, M. P., Kelley, C., Graf, R., Langen, B., Logue, S., Brennan, J., Jiang, L., Charych, E., Egerland, U., Liu, F., Marquis, K. L., Malamas, M., Hage, T., Comery, T. A., \& Brandon, N. J. (2009). Phosphodiesterase 10A inhibitor activity in preclinical models of the positive, cognitive, and negative symptoms of schizophrenia. $J$ Pharmacol Exp Ther, 331, 574-590.

Gresack, J. E., Seymour, P. A., Schmidt, C. J., \& Risbrough, V. B. (2013). Inhibition of phosphodiesterase 10A has differential effects on dopamine D1 and D2 receptor modulation of sensorimotor gating. Psychopharmacology (Berl).

Gurney, M. E., Burgin, A. B., Magnusson, O. T., \& Stewart, L. J. (2011). Small molecule allosteric modulators of phosphodiesterase 4. Handb Exp Pharmacol, 167-192.

Hajos, M. (2006). Targeting information-processing deficit in schizophrenia: a novel approach to psychotherapeutic drug discovery. Trends Pharmacol Sci, 27, 391-398.

Halene, T. B., \& Siegel, S. J. (2008). Antipsychotic-like properties of phosphodiesterase 4 inhibitors: evaluation of 4-(3-butoxy-4-methoxybenzyl)-2-imidazolidinone (RO-20-1724) with auditory event-related potentials and prepulse inhibition of startle. J Pharmacol Exp Ther, 326, 230239.

Imanishi, T., Sawa, A., Ichimaru, Y., Miyashiro, M., Kato, S., Yamamoto, T., \& Ueki, S. (1997). Ameliorating effects of rolipram on experimentally induced impairments of learning and memory in rodents. Eur J Pharmacol, 321, 273-278.

Iyo, M., Bi, Y., Hashimoto, K., Inada, T., \& Fukui, S. (1996). Prevention of methamphetamine-induced behavioral sensitization in rats by a cyclic AMP phosphodiesterase inhibitor, rolipram. Eur J Pharmacol, 312, 163-170.

Izquierdo, I., Barros, D. M., Mello e Souza, T., de Souza, M. M., Izquierdo, L. A., \& Medina, J. H. (1998). Mechanisms for memory types differ. Nature, 393, 635-636.

Javitt, D. C. (2009). Sensory processing in schizophrenia: neither simple nor intact. Schizophr Bull, 35, 1059-1064.

Jessen, F., Kucharski, C., Fries, T., Papassotiropoulos, A., Hoenig, K., Maier, W., \& Heun, R. (2001). Sensory gating deficit expressed by a disturbed suppression of the P50 event-related potential in patients with Alzheimer's disease. Am J Psychiatry, 158, 1319-1321.

Kanes, S. J., Tokarczyk, J., Siegel, S. J., Bilker, W., Abel, T., \& Kelly, M. P. (2007). Rolipram: a specific phosphodiesterase 4 inhibitor with potential antipsychotic activity. Neuroscience, 144, 239246.

Kehne, J. H., Boulis, N. M., \& Davis, M. (1991). Effects of the phosphodiesterase inhibitor rolipram on the acoustic startle response in rats. Psychopharmacology (Berl), 105, 27-36.

Kiyatkin, E. A. (2002). Dopamine in the nucleus accumbens: cellular actions, drug- and behaviorassociated fluctuations, and a possible role in an organism's adaptive activity. Behav Brain Res, 137, 27-46.

Klamer, D., Palsson, E., Revesz, A., Engel, J. A., \& Svensson, L. (2004). Habituation of acoustic startle is disrupted by psychotomimetic drugs: differential dependence on dopaminergic and nitric oxide modulatory mechanisms. Psychopharmacology (Berl), 176, 440-450.

Kleiman, R. J., Chapin, D. S., Christoffersen, C., Freeman, J., Fonseca, K. R., Geoghegan, K. F., Grimwood, S., Guanowsky, V., Hajos, M., Harms, J. F., Helal, C. J., Hoffmann, W. E., Kocan, G. P., Majchrzak, M. J., McGinnis, D., McLean, S., Menniti, F. S., Nelson, F., Roof, R., Schmidt, A. W., Seymour, P. A., Stephenson, D. T., Tingley, F. D., Vanase-Frawley, M., Verhoest, P. R., \& Schmidt, C. J. (2012). Phosphodiesterase 9A regulates central cGMP and modulates 
responses to cholinergic and monoaminergic perturbation in vivo. J Pharmacol Exp Ther, 341, 396-409.

Knudsen, E. I. (2007). Fundamental components of attention. Annu Rev Neurosci, 30, 57-78.

Koch, M. (1999). The neurobiology of startle. Prog Neurobiol, 59, 107-128.

Koch, M., Kungel, M., \& Herbert, H. (1993). Cholinergic neurons in the pedunculopontine tegmental nucleus are involved in the mediation of prepulse inhibition of the acoustic startle response in the rat. Exp Brain Res, 97, 71-82.

Koob, G. F., \& Bloom, F. E. (1988). Cellular and molecular mechanisms of drug dependence. Science, $242,715-723$.

Kuroiwa, M., Snyder, G. L., Shuto, T., Fukuda, A., Yanagawa, Y., Benavides, D. R., Nairn, A. C., Bibb, J. A., Greengard, P., \& Nishi, A. (2012). Phosphodiesterase 4 inhibition enhances the dopamine D1 receptor/PKA/DARPP-32 signaling cascade in frontal cortex. Psychopharmacology (Berl), 219, 1065-1079.

Lakhan, S. E., \& Kirchgessner, A. (2012). Prescription stimulants in individuals with and without attention deficit hyperactivity disorder: misuse, cognitive impact, and adverse effects. Brain and Behavior, 2, 661-677.

Lakics, V., Karran, E. H., \& Boess, F. G. (2010). Quantitative comparison of phosphodiesterase mRNA distribution in human brain and peripheral tissues. Neuropharmacology, 59, 367-374.

Le Moal, M., \& Simon, H. (1991). Mesocorticolimbic dopaminergic network: functional and regulatory roles. Physiol Rev, 71, 155-234.

Leitner, D. S., \& Cohen, M. E. (1985). Role of the inferior colliculus in the inhibition of acoustic startle in the rat. Physiol Behav, 34, 65-70.

Lesch, K. P., Selch, S., Renner, T. J., Jacob, C., Nguyen, T. T., Hahn, T., Romanos, M., Walitza, S., Shoichet, S., Dempfle, A., Heine, M., Boreatti-Hümmer, A., Romanos, J., Gross-Lesch, S., Zerlaut, H., Wultsch, T., Heinzel, S., Fassnacht, M., Fallgatter, A., Allolio, B., Schäfer, H., Warnke, A., Reif, A., Ropers, H. H., \& Ullmann, R. (2010). Genome-wide copy number variation analysis in attention-deficit/hyperactivity disorder: association with neuropeptide $Y$ gene dosage in an extended pedigree. Mol Psychiat, 16, 491-503.

Li, L., Korngut, L. M., Frost, B. J., \& Beninger, R. J. (1998). Prepulse inhibition following lesions of the inferior colliculus: prepulse intensity functions. Physiol Behav, 65, 133-139.

Lijffijt, M., Moeller, F. G., Boutros, N. N., Burroughs, S., Lane, S. D., Steinberg, J. L., \& Swann, A. C. (2009). The Role of Age, Gender, Education, and Intelligence in P50, N100, and P200 Auditory Sensory Gating. J Psychophysiol, 23, 52-62.

Lingenhohl, K., \& Friauf, E. (1994). Giant neurons in the rat reticular formation: a sensorimotor interface in the elementary acoustic startle circuit? J Neurosci, 14, 1176-1194.

Lipina, T., \& Roder, J. (2009). A new model of the disrupted latent inhibition in C57BL/6J mice after bupropion treatment. Psychopharmacology, 208, 487-498.

Lipina, T. V., Palomo, V., Gil, C., Martinez, A., \& Roder, J. C. (2013). Dual inhibitor of PDE7 and GSK-3 VP1.15 acts as antipsychotic and cognitive enhancer in C57BL/6J mice. Neuropharmacology, 64, 205-214.

Lobo, M. K., \& Nestler, E. J. (2011). The striatal balancing act in drug addiction: distinct roles of direct and indirect pathway medium spiny neurons. Front Neuroanat, 5, 41.

Lu, Y. F., Kandel, E. R., \& Hawkins, R. D. (1999). Nitric oxide signaling contributes to late-phase LTP and CREB phosphorylation in the hippocampus. J Neurosci, 19, 10250-10261.

Lugnier, C. (2006). Cyclic nucleotide phosphodiesterase (PDE) superfamily: a new target for the development of specific therapeutic agents. Pharmacol Ther, 109, 366-398.

Malamas, M. S., Stange, H., Schindler, R., Lankau, H. J., Grunwald, C., Langen, B., Egerland, U., Hage, T., Ni, Y., Erdei, J., Fan, K. Y., Parris, K., Marquis, K. L., Grauer, S., Brennan, J., Navarra, R., Graf, R., Harrison, B. L., Robichaud, A., Kronbach, T., Pangalos, M. N., Brandon, N. J., \& Hoefgen, N. (2012). Novel triazines as potent and selective phosphodiesterase 10A inhibitors. Bioorg Med Chem Lett, 22, 5876-5884. 
Mansbach, R. S. (1991). Effects of NMDA receptor ligands on sensorimotor gating in the rat. Eur J Pharmacol, 202, 61-66.

Mattson, M. P., Chan, S. L., \& Duan, W. (2002). Modification of brain aging and neurodegenerative disorders by genes, diet, and behavior. Physiol Rev, 82, 637-672.

Maxwell, C. R., Kanes, S. J., Abel, T., \& Siegel, S. J. (2004). Phosphodiesterase inhibitors: a novel mechanism for receptor-independent antipsychotic medications. Neuroscience, 129, 101107.

McGaugh, J. L. (1989). Dissociating learning and performance: drug and hormone enhancement of memory storage. Brain Res Bull, 23, 339-345.

Mears, R. P., Boutros, N. N., \& Cromwell, H. C. (2009). Reduction of prelimbic inhibitory gating of auditory evoked potentials after fear conditioning. Behav Neurosci, 123, 315-327.

Mears, R. P., Klein, A. C., \& Cromwell, H. C. (2006). Auditory inhibitory gating in medial prefrontal cortex: Single unit and local field potential analysis. Neuroscience, 141, 47-65.

Megens, A. A., Hendrickx, H. M., Hens, K. A., Fonteyn, I., Langlois, X., Lenaerts, I., Somers, M. V., de Boer, P., \& Vanhoof, G. (2014). Pharmacology of JNJ-42314415, a centrally active phosphodiesterase 10A (PDE10A) inhibitor: a comparison of PDE10A inhibitors with D2 receptor blockers as potential antipsychotic drugs. J Pharmacol Exp Ther, 349, 138-154.

Mehta, M. A., Owen, A. M., Sahakian, B. J., Mavaddat, N., Pickard, J. D., \& Robbins, T. W. (2000). Methylphenidate enhances working memory by modulating discrete frontal and parietal lobe regions in the human brain. J Neurosci, 20, RC65.

Messier, C. (2004). Glucose improvement of memory: a review. Eur J Pharmacol, 490, 33-57.

Miyazato, H., Skinner, R. D., \& Garcia-Rill, E. (1999). Neurochemical modulation of the P13 midlatency auditory evoked potential in the rat. Neuroscience, 92, 911-920.

Mori, T., Baba, J., Ichimaru, Y., \& Suzuki, T. (2000). Effects of rolipram, a selective inhibitor of phosphodiesterase 4 , on hyperlocomotion induced by several abused drugs in mice. Jpn J Pharmacol, 83, 113-118.

Nestler, E. J., Berhow, M. T., \& Brodkin, E. S. (1996). Molecular mechanisms of drug addiction: adaptations in signal transduction pathways. Mol Psychiatry, 1, 190-199.

Nishi, A., Kuroiwa, M., Miller, D. B., O'Callaghan, J. P., Bateup, H. S., Shuto, T., Sotogaku, N., Fukuda, T., Heintz, N., Greengard, P., \& Snyder, G. L. (2008). Distinct roles of PDE4 and PDE10A in the regulation of cAMP/PKA signaling in the striatum. J Neurosci, 28, 10460-10471.

Nishi, A., Kuroiwa, M., \& Shuto, T. (2011). Mechanisms for the modulation of dopamine d(1) receptor signaling in striatal neurons. Front Neuroanat, 5, 43.

Nunes, F., Ferreira-Rosa, K., Pereira Mdos, S., Kubrusly, R. C., Manhaes, A. C., Abreu-Villaca, Y., \& Filgueiras, C. C. (2011). Acute administration of vinpocetine, a phosphodiesterase type 1 inhibitor, ameliorates hyperactivity in a mice model of fetal alcohol spectrum disorder. Drug Alcohol Depend, 119, 81-87.

Paine, T. A., Neve, R. L., \& Carlezon, W. A., Jr. (2009). Attention deficits and hyperactivity following inhibition of cAMP-dependent protein kinase within the medial prefrontal cortex of rats. Neuropsychopharmacology, 34, 2143-2155.

Parrott, A. M., A. Moss, M. Scholey, A. (2005). Understanding Drugs and Behaviour. Psychol Med, 35, 458-458.

Pérez-Torres, S., Miró, X., Palacios, J.M., Cortés, R., Puigdoménech, P., Mengod, G. (2000). Phosphodiesterase type 4 isozymes expression in human brain examined by in situ hybridization histochemistry and[3H]rolipram binding autoradiography. Comparison with monkey and rat brain. J Chem Neuroanat, 20, 349-374.

Petersen, S. E., \& Posner, M. I. (2012). The attention system of the human brain: 20 years after. Annu Rev Neurosci, 35, 73-89.

Piccart, E., De Backer, J. F., Gall, D., Lambot, L., Raes, A., Vanhoof, G., Schiffmann, S., \& D'Hooge, R. (2014). Genetic deletion of PDE10A selectively impairs incentive salience attribution and decreases medium spiny neuron excitability. Behav Brain Res, 268, 48-54. 
Posner, M. I., \& Petersen, S. E. (1990). The attention system of the human brain. Annu Rev Neurosci, $13,25-42$.

Prickaerts, J. (2010). Phosphodiesterase Inhibitors. In I. Stolerman (Ed.), Encyclopedia of Psychopharmacology (pp. 1022-1028): Springer Berlin Heidelberg.

Raheem, I. T., Breslin, M. J., Fandozzi, C., Fuerst, J., Hill, N., Huszar, S., Kandebo, M., Kim, S. H., Ma, B., McGaughey, G., Renger, J. J., Schreier, J. D., Sharma, S., Smith, S., Uslaner, J., Yan, Y., Coleman, P. J., \& Cox, C. D. (2012). Discovery of tetrahydropyridopyrimidine phosphodiesterase 10A inhibitors for the treatment of schizophrenia. Bioorg Med Chem Lett, 22, 5903-5908.

Redrobe, J. P., Jorgensen, M., Christoffersen, C. T., Montezinho, L. P., Bastlund, J. F., Carnerup, M., Bundgaard, C., Lerdrup, L., \& Plath, N. (2014). In vitro and in vivo characterisation of Lu AF64280, a novel, brain penetrant phosphodiesterase (PDE) 2A inhibitor: potential relevance to cognitive deficits in schizophrenia. Psychopharmacology (Berl).

Reneerkens, O., Sambeth, A., Ramaekers, J., Steinbusch, H., Blokland, A., \& Prickaerts, J. (2013a). The effects of the phosphodiesterase type 5 inhibitor vardenafil on cognitive performance in healthy adults: a behavioral- electroencephalography study. J Psychopharmacol, 27, 600-608.

Reneerkens, O. A., Rutten, K., Steinbusch, H. W., Blokland, A., \& Prickaerts, J. (2009). Selective phosphodiesterase inhibitors: a promising target for cognition enhancement. Psychopharmacology (Berl), 202, 419-443.

Reneerkens, O. A., Sambeth, A., Blokland, A., \& Prickaerts, J. (2013b). PDE2 and PDE10, but not PDE5, inhibition affect basic auditory information processing in rats. Behav Brain Res, 250, 251-256.

Rodefer, J. S., Murphy, E. R., \& Baxter, M. G. (2005). PDE10A inhibition reverses subchronic PCPinduced deficits in attentional set-shifting in rats. Eur J Neurosci, 21, 1070-1076.

Rodefer, .JS., Saland, S.K., \& Eckrich, S.J. (2012). Selective phosphodiesterase inhibitors improve performance on the ED/ID cognitive task in rats. Neuropharmacology, 62, 1182-1190.

Rodriguez-Moreno, A., \& Sihra, T. S. (2013). Presynaptic kainate receptor-mediated facilitation of glutamate release involves Ca2+-calmodulin and PKA in cerebrocortical synaptosomes. FEBS Lett, 587, 788-792.

Rutten, K., Basile, J. L., Prickaerts, J., Blokland, A., \& Vivian, J. A. (2008). Selective PDE inhibitors rolipram and sildenafil improve object retrieval performance in adult cynomolgus macaques. Psychopharmacology, 196, 643-648.

Salamone, J. D., Correa, M., Mingote, S. M., \& Weber, S. M. (2005). Beyond the reward hypothesis: alternative functions of nucleus accumbens dopamine. Curr Opin Pharmacol, 5, 34-41.

Sambeth, A., Maes, J. H., Van Luijtelaar, G., Molenkamp, I. B., Jongsma, M. L., \& Van Rijn, C. M. (2003). Auditory event-related potentials in humans and rats: effects of task manipulation. Psychophysiology, 40, 60-68.

Sanchez, J. J., Abreu, P., \& Gonzalez, M. C. (2002). Sodium nitroprusside stimulates L-DOPA release from striatal tissue through nitric oxide and cGMP. Eur J Pharmacol, 438, 79-83.

Sarvey, J. M., Burgard, E. C., \& Decker, G. (1989). Long-term potentiation: studies in the hippocampal slice. J Neurosci Methods, 28, 109-124.

Schmidt, C. J., Chapin, D. S., Cianfrogna, J., Corman, M. L., Hajos, M., Harms, J. F., Hoffman, W. E., Lebel, L. A., McCarthy, S. A., Nelson, F. R., Proulx-LaFrance, C., Majchrzak, M. J., Ramirez, A. D., Schmidt, K., Seymour, P. A., Siuciak, J. A., Tingley, F. D., 3rd, Williams, R. D., Verhoest, P. R., \& Menniti, F. S. (2008). Preclinical characterization of selective phosphodiesterase 10A inhibitors: a new therapeutic approach to the treatment of schizophrenia. $J$ Pharmacol Exp Ther, 325, 681-690.

Schoffelmeer, A. N., Wardeh, G., \& Mulder, A. H. (1985). Cyclic AMP facilitates the electrically evoked release of radiolabelled noradrenaline, dopamine and 5-hydroxytryptamine from rat brain slices. Naunyn Schmiedebergs Arch Pharmacol, 330, 74-76.

Schroeder, J. A., Ruta, J. D., Gordon, J. S., Rodrigues, A. S., \& Foote, C. C. (2012). The phosphodiesterase inhibitor isobutylmethylxanthine attenuates behavioral sensitization to cocaine. Behav Pharmacol, 23, 310-314. 
Schultheiss, D., Muller, S. V., Nager, W., Stief, C. G., Schlote, N., Jonas, U., Asvestis, C., Johannes, S., \& Munte, T. F. (2001). Central effects of sildenafil (Viagra) on auditory selective attention and verbal recognition memory in humans: a study with event-related brain potentials. World $J$ Urol, 19, 46-50.

Scott Bitner, R. (2012). Cyclic AMP response element-binding protein (CREB) phosphorylation: a mechanistic marker in the development of memory enhancing Alzheimer's disease therapeutics. Biochem Pharmacol, 83, 705-714.

Sibley, D. R., Monsma, F. J., Jr., \& Shen, Y. (1993). Molecular neurobiology of dopaminergic receptors. Int Rev Neurobiol, 35, 391-415.

Siuciak, J. A., McCarthy, S. A., Chapin, D. S., \& Martin, A. N. (2008). Behavioral and neurochemical characterization of mice deficient in the phosphodiesterase-4B (PDE4B) enzyme. Psychopharmacology (Berl), 197, 115-126.

Smith, S. M., Uslaner, J. M., Cox, C. D., Huszar, S. L., Cannon, C. E., Vardigan, J. D., Eddins, D., Toolan, D. M., Kandebo, M., Yao, L., Raheem, I. T., Schreier, J. D., Breslin, M. J., Coleman, P. J., \& Renger, J. J. (2013). The novel phosphodiesterase 10A inhibitor THPP-1 has antipsychotic-like effects in rat and improves cognition in rat and rhesus monkey. Neuropharmacology, 64, 215223.

Sotty, F., Montezinho, L. P., Steiniger-Brach, B., \& Nielsen, J. (2009). Phosphodiesterase 10A inhibition modulates the sensitivity of the mesolimbic dopaminergic system to Damphetamine: involvement of the D1-regulated feedback control of midbrain dopamine neurons. J Neurochem, 109, 766-775.

Sutcliffe, J.S., Beaumont, V., Watson, J.M., Chew, C.S., Beconi, M., Hutcheson, D.M., Dominguez, C., \& Munoz-Sanjuan, I. (2014). Efficacy of selective PDE4D negative allosteric modulators in the object retrieval task in female cynomolgus monkeys (macaca fascicularis). PLoS One, 9, e102449

Swerdlow, N. R., \& Geyer, M. A. (1993). Prepulse inhibition of acoustic startle in rats after lesions of the pedunculopontine tegmental nucleus. Behav Neurosci, 107, 104-117.

Swerdlow, N. R., Vaccarino, F. J., Amalric, M., \& Koob, G. F. (1986). The neural substrates for the motor-activating properties of psychostimulants: a review of recent findings. Pharmacol Biochem Behav, 25, 233-248.

Trifilieff, P., \& Martinez, D. (2014). Imaging addiction: D2 receptors and dopamine signaling in the striatum as biomarkers for impulsivity. Neuropharmacology, 76 Pt B, 498-509.

Uylings, H. B., Groenewegen, H. J., \& Kolb, B. (2003). Do rats have a prefrontal cortex? Behav Brain Res, 146, 3-17.

Vardigan, J. D., Converso, A., Hutson, P. H., \& Uslaner, J. M. (2011). The selective phosphodiesterase 9 (PDE9) Inhibitor PF-04447943 attenuates a scopolamine-induced deficit in a novel rodent attention task. J Neurogen, 25, 120-126.

Weber, M., Breier, M., Ko, D., Thangaraj, N., Marzan, D. E., \& Swerdlow, N. R. (2009). Evaluating the antipsychotic profile of the preferential PDE10A inhibitor, papaverine. Psychopharmacology (Berl), 203, 723-735.

Weiner, I. (2003). The "two-headed" latent inhibition model of schizophrenia: modeling positive and negative symptoms and their treatment. Psychopharmacology (Berl), 169, 257-297.

Willott, J. F., Carlson, S., \& Chen, H. (1994). Prepulse inhibition of the startle response in mice: relationship to hearing loss and auditory system plasticity. Behav Neurosci, 108, 703-713.

Witten, L., Oranje, B., Mork, A., Steiniger-Brach, B., Glenthoj, B. Y., \& Bastlund, J. F. (2014). Auditory sensory processing deficits in sensory gating and mismatch negativity-like responses in the social isolation rat model of schizophrenia. Behav Brain Res, 266, 85-93.

Wu, M. F., Suzuki, S. S., \& Siegel, J. M. (1988). Anatomical distribution and response patterns of reticular neurons active in relation to acoustic startle. Brain Res, 457, 399-406.

Zhang, H. T. (2010). Phosphodiesterase Targets for Cognitive Dysfunction and Schizophrenia--a New York Academy of Sciences Meeting. IDrugs, 13, 166-168. 
Zhou, D., Ma, Y., Liu, N., Chen, L., He, M., \& Miao, Y. (2008). Influence of physical parameters of sound on the sensory gating effects of N40 in rats. Neurosci Lett, 432, 100-104. 


\section{Chapter 3}

Phosphodiesterase inhibition and regulation of dopaminergic frontal and striatal functioning: clinical implications

P.R.A. Heckman, M.A. van Duinen, E.P.P. Bollen, A. Nishi, L. Wennogle, A. Blokland and J. Prickaerts

International Journal of Neuropsychopharmacology (2016),19, 1-16 


\section{Abstract}

Background: The fronto-striatal circuits are the common neurobiological basis for neuropsychiatric disorders including schizophrenia, Parkinson's disease, Huntington's disease, attention deficit hyperactivity disorder (ADHD), obsessive-compulsive disorder and Tourette's syndrome. Frontostriatal circuits consist of motor circuits, associative circuits and limbic circuits. All circuits share two common features. Firstly, all fronto-striatal circuits consist of hyper direct, direct and indirect pathways. Secondly, all fronto-striatal circuits are modulated by dopamine. Intracellularly, the effect of dopamine is largely mediated through the cyclic adenosine monophosphate (CAMP)/protein kinase A (PKA) signaling cascade with an additional role for the cyclic guanosine monophosphate (cGMP)/ protein kinase G (PKG) pathway, both of which can be regulated by phosphodiesterases (PDEs). PDEs are thus a potential target for pharmacological intervention in neuropsychiatric disorders related to dopaminergic regulation of fronto-striatal circuits.

Methods: Clinical studies of the effects of different phosphodiesterase inhibitors (PDE-Is) on cognition, affect and motor function in relation to the fronto-striatal circuits are reviewed.

Results: Several selective PDE-Is have positive effects on cognition, affect and motor function in relation to the fronto-striatal circuits.

Conclusion: Increased understanding of the subcellular localization and unraveling of the signalosome concept of PDEs including its function and dysfunction in the fronto-striatal circuits will contribute to the design of new specific inhibitors and enhance the potential of PDE-Is as therapeutics in frontostriatal circuits.

Keywords: fronto-striatal circuits, dopamine, phosphodiesterase, phosphodiesterase inhibitors, cyclic adenosine monophosphate 


\section{Introduction}

Several neuropsychiatric disorders, including Parkinson's disease, Huntington's disease, attentiondeficit hyperactivity disorder (ADHD), Tourette's syndrome, schizophrenia and obsessive-compulsive disorder, share the fronto-striatal circuits, also known as cortico-striatal-thalamic circuits, as their neurobiological basis. The fronto-striatal circuits comprise motor, cognitive and limbic circuits (Alexander et al., 1986; Alexander and Crutcher, 1990; Alexander et al., 1990). These circuits operate in a very complex manner which is extensively described elsewhere (Surmeier et al., 2007; Haber and Rauch, 2010; Gerfen and Surmeier, 2011; Surmeier et al., 2011; Calabresi et al., 2014). Dysfunction of these circuits produces the wide range of motor, cognitive and affective symptoms observed in related neuropsychiatric disorders. One prominent feature of the complex functioning of the frontostriatal circuits is their modulation by dopamine, both at the level of the frontal cortex as well as the striatum. As a result, dopaminergic receptors are strongly expressed throughout all fronto-striatal circuits (Gerfen and Surmeier, 2011; Nishi et al., 2011; Kuroiwa et al., 2012). Unsurprisingly, dopaminergic medication has been the first-line therapy for several disorders related to dysfunctional fronto-striatal circuits, however efficacy is often moderate at best and accompanied by severe side effects (e.g. ADHD, schizophrenia and Parkinson's disease).

DA originating from substantia nigra pars compacta (SNc) and/or ventral tegmental area (VTA) (nigrostriatal and mesolimbic pathways) binds to both DA type1 (D1) receptors and DA type2 (D2) receptors on medium spiny neurons (MSNs) in the striatum (Gerfen and Surmeier, 2011). D1 receptors are mainly found on MSNs of the direct pathway and D2 receptors are mainly found on MSNs of the indirect pathway where they establish antagonistic interactions with adenosine $A_{2 a}$ receptors (Gerfen et al., 1990; Ferre et al., 2011). Additionally, DA released from VTA (mesocortical pathway) also binds to D1 receptors in the frontal cortex (Kuroiwa et al., 2012). D1 receptors activate the $\mathrm{G} \alpha_{\mathrm{s} / \text { olf }}$ family of $\mathrm{G}$ proteins to stimulate cyclic adenosine monophosphate (cAMP) production and thereby striatonigral and frontal signaling (Sibley et al., 1993; Beaulieu and Gainetdinov, 2011). In contrast, the $\mathrm{D} 2$ receptors couple to the $\mathrm{G}_{\mathrm{i} / \mathrm{o}}$ family of $\mathrm{G}$ proteins and thus induce inhibition of cAMP production, thereby inhibiting striatopallidal signaling which eventually leads to disinhibition of the frontal cortex (see figure 1). Actions of the DA receptors in both pathways can be viewed as synergistically or complementary.

Intracellularly, the effect of DA on striatonigral, striatopallidal and frontal neurons, is largely mediated through the cAMP-activated cascade (Nishi et al., 2008; Nishi and Snyder, 2010; Nishi et al., 2011; Kuroiwa et al., 2012). cAMP is synthesized from adenosine triphosphate (ATP) by adenylyl cyclase (AC) which is activated directly by activated G-protein coupled receptors, or by calmodulin- 
dependent protein kinase II (CaMKII) after $\mathrm{Ca}^{2+}$ influx. cAMP affects synaptic plasticity through both presynaptic neurotransmitter release and postsynaptic intracellular pathways (see figure 1). The former might be mediated via a presynaptic calcium $\left(\mathrm{Ca}^{2+}\right) /$ calmodulin-dependent protein kinase (CaMK)/CAMP/CAMP-dependent protein kinase (PKA) cascade and elevation of CAMP has been found to result in the synthesis and/or release of several neurotransmitters including two main players in the fronto-striatal circuits: glutamate and DA (Schoffelmeer et al., 1985; Imanishi et al., 1997; Rodriguez-Moreno and Sihra, 2013).

The influence on postsynaptic intracellular pathways occurs through activation of postsynaptic PKA by cAMP produced by $\mathrm{AC}$ stimulated by either glutamatergic-induced $\mathrm{Ca}^{2+}$ influx or DA signalingstimulated $G_{s}$. PKA exerts several effects related to neuroplasticity and neuroprotection. The fastest postsynaptic response in relation to neuroplasticity mediated by cyclic nucleotides is the activation and insertion of stored receptors by PKA through phosphorylation of GluR1 subunits promoting $\alpha$ amino-3-hydroxy-5-methyl-4-isoxazolepropionic acid (AMPA) receptor trafficking into the postsynaptic membrane for potentiation of glutamatergic transmission (Song et al., 2013). In addition to the mobilization and membrane insertion of stored receptors, the process of protein synthesis (e.g. AMPA receptors) further increases neuroplasticity (Carew and Sutton, 2001; Izquierdo et al., 2006).

PKA also phosphorylates CAMP response element- binding protein (CREB) (Mayr and Montminy, 2001) and Dopamine- and cAMP-Regulated PhosphoProtein MR 32 kDa (DARPP-32) (Greengard, 2001; Svenningsson et al., 2004). Phosphorylated CREB (pCREB) is also involved in neuroplasticity (e.g. synthesis of other proteins)(Impey et al., 1996; Lu et al., 1999; Sakamoto et al., 2011) and neuroprotection (e.g. neuronal arborization, synaptogenesis and neurogenesis) (Mantamadiotis et al., 2002; Bruel-Jungerman et al., 2006; Sakamoto et al., 2011). One of the genes transcribed by pCREB is bdnf (Scott Bitner, 2012). After release, the protein BDNF binds to the tropomyosin-related kinase $B(T r k B)$ receptor, which is the receptor with the highest affinity for BDNF. BDNF is involved in the proliferation, survival and differentiation of new neurons (i.e., neurogenesis in the brain)(Minichiello, 2009).

In addition, the activity-dependent release of BDNF and subsequent TrkB-mediated activation of CREB is also an important mechanism of enhancing neuronal communication, specifically in active neurons of the brain. For instance, BDNF increases synaptic strength with adjacent neurons by processes like long-term potentiation (LTP), thus ameliorating their connectivity (Lu et al., 2008; 
Minichiello, 2009). Interestingly, LTP itself has been linked to both synaptogenesis and neurogenesis (Bruel-Jungerman et al., 2006).

DARPP-32 is phosphorylated at Thr34 in both striatal and frontal neurons. DARPP-32 converts thereby into a potent inhibitor of protein phosphatase-1 (PP-1). DARPP-32 is also phosphorylated at Thr75 by Cdk5 and this converts DARPP-32 into an inhibitor of PKA. Thus, DARPP-32 has the unique property of being a dual-function protein, acting either as an inhibitor of PP-1 or of PKA influencing neuroplasticity (Svenningsson et al., 2004). The inhibition of PP-1 controls the phosphorylation state and activity of many downstream physiological effectors, including various neurotransmitter receptors (e.g. AMPA receptor GluR1 subunit, N-methyl-D-aspartate (NMDA) receptor NR1 subunit), ion channels and pumps (e.g. N/P-type $\mathrm{Ca}^{2+}$ channels, $\mathrm{Na}^{+}$channel, $\mathrm{Na}^{+}, \mathrm{K}^{+}$-ATPase), and transcription factors (e.g. CREB, c-Fos, $\triangle$ FosB)(Greengard et al., 1999). Striatal LTP and long-term depression (LTD) are dependent on CAMP and DARPP-32 phosphorylation (Calabresi et al., 2000).

The cAMP/PKA cascade is thus a potential target for pharmacological intervention in neuropsychiatric disorders related to dopaminergic frontal and striatal dysfunction. CAMP is degraded by CAMPspecific phosphodiesterases (PDEs) and dual substrate PDEs. Eleven PDE families have been described, distinguished by molecular properties, substrate specificity, and regulation (Bender and Beavo, 2006). These enzymes are expressed in unique and overlapping patterns throughout the body and central nervous system (CNS) (Lakics et al., 2010; see Table 1). Selective phosphodiesterase inhibitors (PDE-Is) prevent the degradation of cyclic nucleotides leading to increased concentrations of CAMP. Due to the differential expression of PDE subtypes in one or more of the frontal and striatal pathways or dopaminergic terminals, different subtype-specific PDE-Is enable stimulation of dopamine synthesis, inhibtion of D2 receptor signaling or stimulation of D1 receptor signaling (Nishi et al., 2011). However, the level of expression of different PDE family members in these fronto-striatal circuits in both physiological and pathological conditions is incompletely understood and a subject of intense investigation. In the fronto-striatal circuits, the main therapeutic mechanism of PDE inhibition is enhanced neuroplasticity and neuroprotection through previously discussed CREB and DARPP-32 signaling cascades (see figure 1). However, known effects of PDE-Is on neuroinflammation and cytokine-mediated responses may play additional roles (Hebb and Robertson, 2008; Wilson and Brandon, 2015).

Table 1. Localization of the different phosphodiesterases (PDEs) in the brain of rodents and humans in adulthood (adapted from Prickaerts, 2015) based on Lakics et al, 2010; Pérez-Torres et al, 2010). 


\begin{tabular}{|c|c|c|}
\hline PDE & Localization in the Body & Localization in the Brain \\
\hline PDE1A-C & Heart, smooth muscles, lungs & $\begin{array}{l}\text { Hippocampus, cortex, olfactory bulb, striatum } \\
\text { (highest expression levels), thalamus, amygdala, } \\
\text { cerebellum; Expression levels are in general } \\
\text { highest for } 1 \mathrm{~A} \text { and lowest for } 1 \mathrm{C}\end{array}$ \\
\hline PDE2A & Heart, adrenal cortex, platelets & $\begin{array}{l}\text { Hippocampus, cortex, striatum, hypothalamus, } \\
\text { amygdala, midbrain }\end{array}$ \\
\hline PDE3 & $\begin{array}{l}\text { Heart, smooth muscles, kidneys, } \\
\text { platelets }\end{array}$ & Throughout the brain low expression levels \\
\hline PDE4A-D & $\begin{array}{l}\text { Wide variety of tissues: e.g., } \\
\text { smooth muscles, lungs, kidneys, } \\
\text { testes }\end{array}$ & $\begin{array}{l}\text { Hippocampus, cortex, olfactory bulb, striatum, } \\
\text { thalamus, hypothalamus, amygdala, midbrain, } \\
\text { cerebellum; Expression levels are in general } \\
\text { highest for 4A-4D (differs per brain structure) } \\
\text { and lowest for 4C }\end{array}$ \\
\hline PDE5A & $\begin{array}{l}\text { Smooth muscles, skeletal } \\
\text { muscles, lungs, kidneys, platelets }\end{array}$ & Hippocampus, cortex, cerebellum \\
\hline PDE6 & Rod and cone cells in retina & Pineal gland \\
\hline PDE7A-B & $\begin{array}{l}\text { Heart, skeletal muscles, liver, } \\
\text { kidneys, testes, pancreas }\end{array}$ & $\begin{array}{l}\text { Hippocampus, cortex, olfactory bulb, striatum, } \\
\text { thalamus, hypothalamus, midbrain; Expression } \\
\text { levels are in general highest for 7B }\end{array}$ \\
\hline PDE8A-B & $\begin{array}{l}\text { Heart, liver, kidneys, lungs, testes, } \\
\text { thyroid }\end{array}$ & $\begin{array}{l}\text { Hippocampus, cortex, olfactory bulb, striatum, } \\
\text { thalamus, hypothalamus, midbrain; Expression } \\
\text { levels are in general highest for } 8 \mathrm{~B}\end{array}$ \\
\hline PDE9A & $\begin{array}{l}\text { Kidneys, spleen, prostate, various } \\
\text { gastrointestinal tissues }\end{array}$ & $\begin{array}{l}\text { Hippocampus, cortex, olfactory bulb, striatum, } \\
\text { thalamus, hypothalamus, amygdala, midbrain, } \\
\text { cerebellum }\end{array}$ \\
\hline PDE10A & $\begin{array}{l}\text { Heart, skeletal muscles, lungs, } \\
\text { liver, kidneys, testes, pancreas, } \\
\text { thyroid }\end{array}$ & $\begin{array}{l}\text { Hippocampus, cortex, striatum (highest } \\
\text { expression levels), midbrain, cerebellum }\end{array}$ \\
\hline PDE11A & $\begin{array}{l}\text { Skeletal muscles, liver, kidneys, } \\
\text { testes, prostate, thyroid }\end{array}$ & Throughout the brain low expression levels \\
\hline
\end{tabular}

Note that this table does not provide information with respect to the level of expression (protein or mRNA) of the different PDEs. 
The integration of individual PDEs into specific signalosomes within different functional compartments has revealed the functional roles of these PDEs and linked the large number of PDE isoforms to the compartmentalized regulation of specific cyclic nucleotide signaling pathways and biological responses. This compartmentalization contributes therefore to both the fine-tuning and specificity of cyclic nucleotide signaling (Jurevicius and Fischmeister, 1996; Zaccolo et al., 2000; Mongillo et al., 2006; Maurice, 2011; Stangherlin et al., 2011; Stangherlin and Zaccolo, 2012). More in detail, compartmentalization provides spatially distinct pools of PKA and PKG to be activated in different ways. This idea was confirmed by the observation of accumulation of CAMP in localized pools (Houslay, 1995). These pools are created by physical interactions between different components of signaling cascades and structural elements of the cell. Localization and activation of both cyclases and PDEs are important determinants in the process of cyclic nucleotide homeostasis by modulating fluctuations in the compartments. For PDEs sequestration and anchoring is the principal mechanism to create cyclic nucleotide gradients (Houslay and Milligan, 1997; Houslay and Adams, 2003). Subsequently, different PKA isoforms are anchored at specific intracellular sites by AKAPs (Akinase anchoring proteins) (Rubin, 1994). AKAPs control the gradients of cAMP in the cell and modify localized target proteins thereby causing sequestration of PKA into distinct cellular compartments. This also applies to the fronto-striatal circuits and is considered the main determinant of the target PDE isoform within a specific neuropsychiatric disorder. In addition, different PDE isoforms can integrate multiple distinct cellular inputs and allow crosstalk between cyclic nucleotides and other signaling networks and systems (Dodge-Kafka et al., 2005; Mongillo et al., 2006; Houslay et al., 2007; Stangherlin et al., 2011; Wilson et al., 2011; Kritzer et al., 2012).

Since the focus of this review is on frontal and striatal dopaminergic regulation, in particular PDE1B, PDE2A, PDE4, PDE7B, PDE9A and PDE10A are of special interest (Lakics et al., 2010). PDE1B, PDE7B and PDE10A are highly enriched in striatum and/or frontal cortex. PDE2A, PDE4 (A, B, D) and PDE9A are more widely distributed but are also expressed in striatum and/or frontal cortex. There is only very limited preclinical data on PDE2A, PDE7A and PDE9A inhibition (e.g. Duinen et al., 2015). To date, most research has been devoted to the potential of PDE1B, PDE4 and PDE10A for regulation of dopaminergic frontal and striatal signaling and therefore these subtypes will be discussed below. 


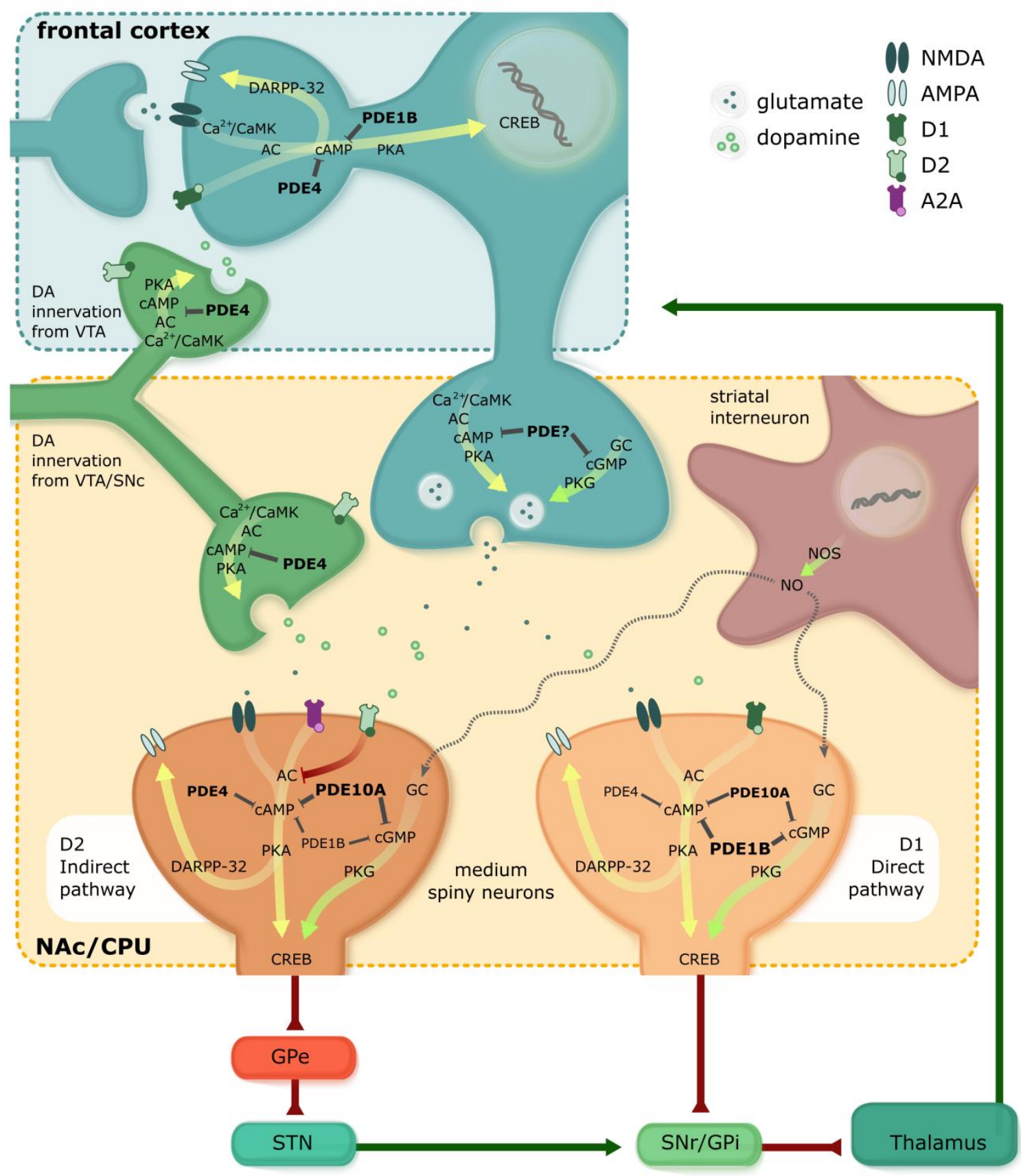

Figure 1. Fronto-striatal circuits originate in the frontal cortex, pass through the basal ganglia, which project via the thalamus back to frontal brain areas. Output neurons in the striatum are medium spiny neurons (MSNs), which consist of direct pathway and indirect pathway neurons. The direct pathway neurons inhibit tonically active neurons in globus pallidus interna (GPi)/substantia nigra pars reticulata ( $\mathrm{SNr}$ ). The indirect pathway neurons activate neurons in GPi/SNr via inhibition of the globus pallidus externa (GPe) and activation of the subthalamic nucleus (STN). Direct and indirect pathway neurons induce opposing effects on the output neurons in GPi/SNr, resulting in dis-inhibition and pro-inhibition of output, respectively. Within the basal ganglia all projections are GABAergic except those from the STN. Main phosphodiesterases (PDES) expressed in frontostriatal circuits are PDE1B, PDE4 and PDE10A. 
PDE1B is generally co-localized with dopamine (DA) D1 receptors in the brain and thought to represent a major inactivation mechanism of D1 receptors. By acting like a DA D1 agonist PDE1B-Is can enhance phosphorylation of cAMP response element binding protein (CREB) as well as Dopamine- and CAMP-Regulated PhosphoProtein MR 32 kDa (DARPP-32) enhancing synaptic transmission (e.g. AMPA receptors), neuron excitability, and synapto- and neurogenesis resulting in neuroplasticity and neuroprotective effects at glutamatergic frontal and fronto-striatal synapses.

Regarding fronto-striatal signaling, the effect of PDE4 inhibition on cyclic adenosine monophosphate (CAMP)/protein kinase A (PKA) signaling is linked to indirect pathway adenosine A2a receptor signaling and has no major role in D1 receptor direct pathway signaling. An opposite situation is observed at frontal dopaminergic signaling. In the frontal cortex PDE4 is -just as PDE1B- localized at DARPP-32 expressing neurons. In contrast to the striatum, PDE4 inhibition enhances DA D1 receptor-induced phosphorylation of DARPP-32 in the frontal cortex, indicating a prominent role of PDE4 in frontal DA receptor signaling. Finally, DA release from DAergic midbrain terminals can be influenced with a PDE4 inhibitor as DA is expressed at DAergic terminals in neurons of the substantia nigra pars compacta (SNc) in which cAMP has been reported to be a strong inducer of tyrosine hydroxylase gene transcription rate and mRNA affecting DA synthesis and release.

In direct pathway neurons, PDE10A inhibition activates CAMP/PKA signaling related to D1 receptor signaling whereas in indirect pathway neurons PDE10A inhibition activates CAMP/PKA signaling by simultaneous potentiation of adenosine A2A receptor signaling and inhibition of D2 receptor signaling. Effects of PDE10A inhibition are suggested to predominate the indirect pathway. In contrast to PDE4 inhibition, PDE10A inhibition does not increase tyrosine hydroxylase phosphorylation and therefore has no effects on DA synthesis and release. Nevertheless, it cannot be ruled out that selective PDE inhibitors might influence both the direct and indirect pathway via enhancing the release of DA from frontal DAergic projections depending on the -to be determined-presence of PDEs in these terminals.

In striatal interneurons containing nitric oxide synthase (NOS), nitric oxide (NO) is produced and diffuses into dendrites of MSNs which contain high levels of guanylate cyclase (GC), which, when activated, lead to the synthesis of cyclic guanosine monophosphate (cGMP). In the striatum, transient elevations in intracellular cGMP -next to CAMP- primarily act to increase neuronal excitability and to facilitate glutamatergic fronto-striatal transmission. Thus, inhibition of selective PDE subtypes can also target the cGMP/protein kinase G (PKG) pathway and have an effect on fronto-striatal functioning.

\section{Phosphodiesterase 1}

\section{Phosphodiesterase 1 and dopamine signaling}

PDE1 hydrolyzes both CAMP and cGMP. PDE1, unlike any other class of PDE, is uniquely activated by the binding of a complex of $\mathrm{Ca}^{2+}$ and calmodulin (CaM). PDE1 is encoded by three separate genes, PDE1A, PDE1B and PDE1C. PDE1B is highly co-localized with D1 receptors in the brain, and is particularly rich in the striatum, hippocampus and prefrontal cortex (Lakics et al., 2010). PDE1 activity 
has first been described as cytosolic, however it now appears that PDE1A is not restricted to the cytosol but is also present in the nucleus where it contributes to the regulation of transcription factors (Nagel et al., 2006). This opens a new field of research in transcriptional regulation. Changes in PDE1 location associated with cell differentiation might contribute to compartmental signaling (Nagel et al., 2006).

Since PDE1B is strongly and selectively expressed in the striatum and frontal cortex it could be a relevant target for modulating fronto-striatal behaviors. However, only a few studies have been published with PDE1-Is (Medina, 2011; Nunes et al., 2011). Indeed, as noted by the authors, in these studies no potent and selective inhibitors of PDE1 isoforms were available for research. Vinpocetine, often referred to as a PDE1-I, has substantial other activities including inhibition of $\mathrm{Na}^{2+}$ channels and IKB kinase (IKK). Vinpocetine therefore should not be considered as a selective PDE1-I. Since PDE1B is activated by $\mathrm{Ca}^{2+}$ and $\mathrm{CaM}$, it provides a mechanism for crosstalk between $\mathrm{Ca}^{2+}$ and cyclic nucleotide signaling (Nishi et al., 2008; Nishi and Snyder, 2010; Nishi et al., 2011). PDE1B was localized to all DARPP-32-positive MSNs indicating expression in both striatal pathways (Nishi et al., 2011). Behavioral profiles of PDE1B knockout (KO) mice showed rather mild behavioral effects. The authors show an increased spontaneous locomotor activity in the presence of methamphetamine administration. Cognitive aspects are reported as similar to wild type. Overall the data suggest predominant effects of PDE1B-Is would be seen in the striatonigral direct pathway (Reed et al., 2002; Ehrman et al., 2006; Siuciak et al., 2007; Zhang, 2010). However, regarding effects on frontal and striatal DA release or effects on cAMP/PKA signaling in the frontal cortex, these areas have so far been understudied.

\section{Implications and clinical overview of PDE1B-Is}

PDE1B is generally co-localized with DA D1 receptors in the brain and thought to represent a major inactivation mechanism of D1 receptors. PDE1B is not membrane bound but contained mainly in a soluble intracellular compartment (Fusco and Giampa, 2015). Targeting this subfamily of PDEs is therefore considered a promising therapeutic strategy in disorders characterized by frontal cognitive dysfunction, like schizophrenia and ADHD. Negative and cognitive symptoms of schizophrenia, are associated with reduced DA (D1) function in the prefrontal cortex, also referred to as hypofrontality (Liemburg et al., 2012; Arnsten, 2013). The reduced prefrontal DA function disturbs the balance of excitatory to inhibitory synaptic interactions in this area (Winterer, 2006). Thus, the decreased ratio of D1/D2 signaling in schizophrenia would favor unstable cortical representation of internal and external stimuli (Winterer and Weinberger, 2004) and as such, affect cognition. Likewise, dopaminergic hypofrontality is observed in ADHD patients (Pliszka, 2005; Sagvolden et al., 2005; 
Arnsten and Pliszka, 2011) and linked to inattentiveness, hyperactivity and impulsivity. By acting supposedly like a DA D1 agonist, a PDE1B-I can enhance phosphorylation of GluR1 subunits, to potentiate glutamatergic fronto-striatal signaling. In addition, potentiation of DA receptors will increase phosphorylation of DARPP-32 and CREB, subsequently inducing gene expression in the prefrontal cortex, and benefiting clinical symptoms by activation of neuroplasticity at prefrontal synapses.

Regarding striatal disorders like movement disorders and positive symptoms in schizophrenia, not much data is available. Assuming effects of PDE1B are indeed preferentially induced in the DA D1 direct pathway, subsequent DARPP-32 and CREB phosphorylation will enhance synaptic transmission, neuron excitability, and synapto-neurogenesis inducing neuroplasticity and neuroprotection at glutamatergic fronto-striatal synapses. In theory, neuropsychiatric disorders related to striatal hypofunction (like hypokinetic movement disorders such as Parkinson's disease), would benefit from stimulated plasticity in striatonigral neurons (Nishino et al., 1993; Heckman et al., 2015). This, in contrast to desired mechanism of action of treatment for hyperkinetic movement disorders (like Huntington's disease) and anti-psychotic treatment, as both preferably target the D2 receptor striatopallidal pathway (Strange, 1998; Walker, 2007). Support for this hypothesis comes from studies that found impaired cyclic nucleotide signaling mechanisms to occur in human Parkinson's disease as well as in experimental animals (Belmaker et al., 1978; Volicer et al., 1986; Nishino et al., 1993; Sancesario et al., 2004). Additional upregulation in PDE1B activity has also been observed following 6-hydroxydopamine (6-OHDA) lesions (as a Parkinson's model) in rats (Sancesario et al., 2004). The opposite has been observed in Huntington's disease (Luthi-Carter et al., 2000; Nucifora et al., 2001). These studies found decreased cyclic nucleotide (cAMP) levels in the deafferented striatum accompanied by decreased PDE1B activity. The decreased PDE1B activity may be compensatory to the decrease in cyclic nucleotide levels. CREB-mediated transcriptional dysregulation has also been reported to occur during Parkinson's disease pathology. PDE1-Is have been tested in an animal model of haloperidol-induced catalepsy. As haloperidol is a potent D2 DA receptor antagonist, interference with D2 DA receptors causes significant motor disturbances seen frequently with schizophrenics treated with antipsychotic medicines. The haloperidol-induced catalepsy model is capable of testing agents for exacerbation or lessening of these motoric effects. The potent and selective PDE1-I, ITI-214 (see below) reversed the haloperidol-induced catalepsy, indicating the potential use of this mechanism to reverse such motoric effects (Wennogle et al., 2010). 
BDNF has been demonstrated to exert protective actions on nigral dopaminergic neurons in in vivo and in vitro models of Parkinson's disease (Hyman et al., 1991; Levivier et al., 1995; Shults et al., 1995; Hung and Lee, 1996; Feng et al., 1999; Mohapel et al., 2005; Sun et al., 2005), whereas inhibition of nigral BDNF expression has been reported to cause dopaminergic neuronal loss (Porritt et al., 2005). Postmortem studies have demonstrated reduced levels of BDNF within the SNc in Parkinson's disease patients (Mogi et al., 1999; Parain et al., 1999; Howells et al., 2000; Chauhan et al., 2001). Furthermore, during in vitro experiments, BDNF has been demonstrated to promote the survival and differentiation of mesencephalic dopaminergic neurons (Hyman et al., 1991; Feng et al., 1999). The enhancement of cerebral cyclic nucleotide levels by PDE1B inhibition would improve CREB mediated signaling mechanisms providing therapeutic effects in Parkinson's disease.

Recently, a set of four clinical studies were performed with a truly selective and potent PDE1-I, ITI214 (Li et al., 2016a). With the exception of work performed with vinpocetine, a non-selective agent as noted above, ITI-214 is the first selective PDE1-I studied in humans. Clinical evaluations included a series of Phase I single and multiple ascending dose studies performed in the United States (US) and Japan. ITI-214 was given orally to healthy volunteers and to patients using once-a-day dosing and was shown to be safe and well-tolerated, with a linear pharmacokinetic profile. This study has been reported in a press release (http://www.intracellulartherapies.com/products-technology/pdeinhibitor-platform.html), where the company concludes that "these studies represent a significant milestone as the first demonstration of the safety of a potent and highly specific PDE1-I in humans".

\section{Phosphodiesterase 4}

\section{Phosphodiesterase 4 and dopamine signaling}

PDE4, which is cAMP-specific, is encoded by four distinct genes in mammals, PDE4A, PDE4B, PDE4C and PDE4D, and is expressed as at least 25 splice variants. Each of these variants has a modular structure consisting of a variant-specific $\mathrm{N}$-terminal domain, regulatory domains (upstream conserved region 1 and 2 (UCR1 and UCR2)), a conserved catalytic domain and an isoform-specific Cterminal domain (McCahill et al., 2008; Gurney et al., 2011; Richter et al., 2013). Transcription of a number of PDE4 genes is activated by the CAMP/PKA/CREB cascade (D'Sa et al., 2002; Le Jeune et al., 2002), and PKA induction of PDE4 genes serves as a long-term feedback mechanism. The N-terminal domain and UCR1/2 interact with variant-specific binding proteins, to direct the subcellular targeting of PDE4 variants (McCahill et al., 2008). Various targeting proteins have been identified, including arrestin, A-kinase anchoring protein (AKAPS), receptor for activated C kinase 1 (RACK1), disrupted in schizophrenia 1 (DISC1), Src, and extracellular receptor kinase (ERK) (see Nishi and Snyder, 2010). 
Nishi and colleagues (Nishi et al., 2008) showed that the inhibition of PDE4 by rolipram weakly enhanced CAMP/PKA signaling both in neostriatal slices and in vivo (Nishi et al., 2008). Rolipram increased the phosphorylation of DARPP-32 but only at high concentrations. Rolipram treatment enhanced adenosine $A_{2 a}$ receptor-mediated phosphorylation of DARPP-32, but had no effect on D1 receptor/CAMP/PKA-mediated phosphorylation at the level of DARPP-32. Enhanced adenosine $A_{2 a}$ receptor-mediated signaling is expected to oppose actions of the DA D2-receptor in striatopallidal neurons. These findings may suggest that PDE4 is exclusively expressed in indirect pathway neurons. However, immunohistochemical analysis of previously mentioned neostriatal slices revealed that PDE4B expression can be found in both pathways but with a higher expression in indirect pathway neurons. Regarding striatal dopaminergic signaling it seems that the effect of PDE4 inhibition on CAMP/PKA signaling is linked to adenosine $A_{2 a}$ receptor signaling and has no major role in striatal DA signaling. An opposite situation is observed at frontal dopaminergic signaling. In the frontal cortex several PDE isoforms are expressed in cortical neurons (Cherry and Davis, 1999; Pérez-Torres et al., 2000). For the mouse frontal cortex it has been described that PDE4B is localized at DARPP-32 expressing neurons (Nishi and Snyder, 2010). In contrast to the striatum, rolipram enhanced DA D1 receptor-induced phosphorylation of DARPP-32 in the frontal cortex, indicating prominent role of PDE4 in frontal DA receptor signaling. Finally, DA is known to be expressed at dopaminergic terminals in neurons of the SNc (Cherry and Davis, 1999), where cAMP has been reported to be a strong inducer of tyrosine hydroxylase $(\mathrm{TH})$ gene transcription rate and mRNA affecting DA synthesis (Kumer and Vrana, 1996; Chen et al., 2008). Rolipram enhanced haloperidol-induced phosphorylation of TH at Ser40 in presynaptic DA terminals with a proportional increase in DA synthesis, though failed to do so in the absence of haloperidol. Also, rolipram enhanced levels of 3,4-Dihydroxyphenylacetic acid (DOPAC) and DOPAC/DA ratio indicating an increased DA metabolism. However, no increase in the level of DA itself was found indicating the absence of a direct effect on DA release (Nishi et al., 2008).

\section{Implications and clinical overview of PDE4-Is}

Compared to PDE1 much more is known regarding the role of PDE4 in frontal and striatal dopaminergic functioning. However, by no means have all the effects been unraveled and all the questions been resolved for PDE4. PDE4 inhibition has been shown to increase dopaminergic tone in striatal neurons by increasing both synthesis and metabolism, though lacking a direct effect on release. It is known that basal ganglia functioning depends on specific amounts of DA in order to function at peak performance. Low levels of DA cause movement difficulties, while excessive DA causes involuntary movements. Even if PDE4 inhibition itself may not be involved in the process of releasing DA, the enhanced production of the DA precursor levodopa by enhanced cAMP-stimulated 
TH gene transcription, may result in enhanced stimulus-driven DA release. PDE4-Is may therefore constitute an interesting treatment for neuropsychiatric disorders involving hypofunctioning striatal DA systems, like Parkinson's disease. Indeed, rolipram has been reported to attenuate MPTP-induced DA depletion in the striatum and reduce the loss of nigral TH-positive neurons in vitro (Hulley et al., 1995a; Yamashita et al., 1997a; Yamashita et al., 1997b) and in vivo (Hulley et al., 1995b; Yang et al., 2008). Next, it remains to be seen if these effects on synthesis and metabolism also apply to frontal dopaminergic terminals arriving from the VTA. If so, PDE4 would be an interesting target for disorders characterized by frontal dopaminergic dysfunction, like ADHD or schizophrenia (cognitive and negative symptoms). Frontal dopaminergic hypofunctioning can not only be opposed by PDE4 inhibition via augmented release of neurotransmitters at dopaminergic terminals, but also, like previously discussed for PDE1B, by means of increased DA D1 receptor/CAMP/PKA signaling inducing DARPP-32 and CREB phosphorylation leading to concomitant gene transcription related to neuronal plasticity. Because PDE4 inhibition affects both these mechanisms, PDE4-Is are particularly interesting as a potential treatment for ADHD and schizophrenia. Finally, in the striatum, PDE4 inhibition regulates adenosine $A_{2 a}$ signaling and is therefore often viewed as exerting DA D2 antagonistic effects, although it may also be viewed as mimicking the effect of an adenosine $A_{2 a}$ agonist. Both would indicate anti-psychotic potential of PDE4-Is by counteracting hyperdopaminergia, which has been confirmed by several studies over the years including early clinical trials (Casacchia et al., 1983; Parkes et al., 1984; Siuciak, 2008). Based on results of rolipram, this latter mechanism is also applicable to Huntington's disease. Rolipram exerted neuroprotective effects in two rodent Huntington's disease models via increased CREB phosphorylation and subsequent targets like BDNF (DeMarch et al., 2007; DeMarch et al., 2008; Fusco and Giampa, 2015). Neuroprotective effects of rolipram were induced by sparing of striatal neurons, prevention of intranuclear inclusion formation and attenuation of microglial reactivity (DeMarch et al., 2008). Furthermore, rolipram was effective in preventing CREB binding protein sequestration into striatal neuronal intranuclear inclusions, sparing interneurons of R6/2 mice and rescuing motor coordination and activity deficits (Giampa et al., 2009b; but see Hannan, 2009). However, there are a range of molecular and cellular mechanisms implicated in the pathogenesis of Huntington's disease (Gil and Rego, 2008).

When examining actual clinical data, the first clinical trials into PDE4 were done in the field of depression research (Esposito et al., 2009). First clinical studies showed a good antidepressant response to rolipram treatment (Zeller et al., 1984; Fleischhacker et al., 1992). However, rolipram produces severe dose-limiting side effects including emesis, headache, gastric hyper secretion, nausea and vomiting. This has put a serious hold on the further development of rolipram and other 
related PDE4-Is. It also prevented rolipram from reaching the market. Yet, a clinical Phase II trial started in 2006 to reevaluate the antidepressant properties of rolipram (estimated study completion date: December 2013). No details are yet available to the scientific community. Another PDE4-I, ND1251, was reported to improve memory in a group of 8 depressed subjects (http://www.outsourcing-pharma.com/Preclinical-Research/PDE4-re-emerges-as-depressiontherapy).

Although rolipram was primarily developed for treating depression (Zeller et al., 1984; Fleischhacker et al., 1992), rolipram has also been investigated in early clinical trials as a treatment for Parkinson's disease (Casacchia et al., 1983; Parkes et al., 1984). Some positive effects of rolipram were observed, however not exceeding efficacy of levodopa or other dopaminergic drugs. At the moment, "second generation" PDE4-Is are being developed, which are supposed to have less-emetic side effects, and are being studied for other disorders besides that of depression. As a result, roflumilast has been approved by the Food and Drug Administration (FDA) in 2011 as an anti-inflammatory drug for the treatment of Chronic Obstructive Pulmonary Disease (COPD) exacerbations (Izquierdo and Aparicio, 2010; Puhan, 2011).

PDE4-Is were also tested in clinical trials as treatment for schizophrenia. Takeda has recently finished a proof of mechanism Phase I clinical study with the PDE4-I roflumilast in combination with second generation antipsychotics in schizophrenia patients (ClinicalTrials.gov Identifier: NCT02079844).

PDE4-Is were also examined as a treatment for Huntington's disease. The new experimental PDE4-I GSK356278 was tested by GlaxoSmithKline as a new treatment for Huntington's disease in 2 subsequent Phase I studies. In 2012, the first Phase I study was completed investigating the safety, tolerability, pharmacokinetics and pharmacodynamics of GSK356278 (ClinicalTrials.gov Identifier: NCT01573819). GSK356278 was well tolerated when it was given as a single dose to healthy people and in this study GlaxoSmithKline the objective was to observe effects of GSK356278 after daily intake. Subsequently, a second Phase I positron emission tomography (PET) brain occupancy study of GSK356278 was conducted in male healthy volunteers (ClinicalTrials.gov Identifier: NCT01602900; no results are disclosed). It is currently unclear whether this PDE4-I treatment is aimed at the motor or cognitive symptoms observed in Huntington's disease.

Of note, Ibudilast (or AV-411) is another PDE4-I in development as an anti-inflammatory drug to treat for instance Amyotrophic Lateral Sclerosis (ALS) (ClinicalTrials.gov Identifier: NCT02238626). However, this compound not only inhibits PDE4 but also serves as a glial activator. CNS applications 
of AV-411 are being explored in clinical Phase II studies, i.e. pain and drug abuse (ClinicalTrials.gov Identifier: NCT00723177, NCT01217970, NCT02025998, NCT01860807).

Additionally, different genetic studies have shown a positive relationship between PDE4B polymorphisms and schizophrenia, which likely results in significantly decreased PDE4B levels as detected in postmortem brain tissue (Fatemi et al., 2008b; Guan et al., 2012). Low PDE4B levels, which might be considered as compensatory mechanism, do not necessarily result in increased cAMP levels as several mechanisms can also be activated that counteract the decreased degradation of CAMP by PDE4B. Another genetic link is related to the gene Disrupted-in Schizophrenia-1 (DISC1; Harrison and Weinberger, 2005). A chromosomal translocation of this gene increases susceptibility for schizophrenia (Millar et al., 2000; Sachs et al., 2005) and interestingly binding of DISC1 to PDE4B is disrupted which might result in an overactivity of the latter (Millar et al., 2005; Murdoch et al., 2007).

\section{Phosphodiesterase 10}

\section{Phosphodiesterase 10 and dopamine signaling}

PDE10, which is encoded by PDE10A, is a dual substrate PDE, hydrolyzing both cAMP and cGMP. PDE10A is present both in striatonigral direct and striatopallidal indirect pathway MSNs (Xie et al., 2006; Nishi et al., 2008). Additionally, PDE10A regulates CAMP/PKA signaling (Nishi et al., 2008) and gene expression (Strick et al., 2010) in the MSNs of both pathways. Interestingly, PDE10A hydrolyzes both CAMP and CGMP, but it has an approximate 20-fold higher affinity for cAMP (Bender and Beavo, 2006) making it an interesting target for disorders involving the fronto-striatal circuits. In the striatum, PDE10A is expressed in both direct and indirect pathway MSNs, but not in interneurons (Xie et al., 2006; Nishi et al., 2008; Sano et al., 2008). Of the three splice variants, PDE10A2 is associated with the membrane, whereas PDE10A1 and PDE10A3 are found in the cytosol (Kotera et al., 2004). In the striatum, mainly PDE10A2 is expressed and it is found at membranes in dendrites and spines of medium spiny neurons (Xie et al., 2006). PDE10A2 is phosphorylated by PKA at Thr16 within the Nterminal region (Kotera et al., 2004). Nishi and colleagues argue that this seems to induce the translocation of PDE10A2 from membrane to cytosol, thereby controlling CAMP/PKA signaling within the spines (Nishi and Snyder, 2010; see also Wilson and Brandon, 2015).

Through this effect on CAMP/PKA signaling, PDE10A inhibition by papaverine showed enhanced phosphorylation of CREB and ERK (Rodefer et al., 2005; Siuciak et al., 2006; Becker and Grecksch, 2008) and of their downstream targets DARPP-32 and GluR1 (Nishi et al., 2008) at PKA sites in striatal 
MSNs both in vitro and in vivo. More specifically, in both direct and indirect pathway neurons, PDE10A shows equal expression patterns (Xie et al., 2006; Nishi et al., 2008; Sano et al., 2008), regulation of CAMP/PKA signaling (Nishi et al., 2008) and gene expression (Strick et al., 2010). However, distinguishing between both pathways, in direct pathway neurons, PDE10A inhibition activates CAMP/PKA signaling related to D1 receptor signaling (Nishi et al., 2008), whereas in indirect pathway neurons PDE10A inhibition activates CAMP/PKA signaling by simultaneous potentiation of adenosine $A_{2 A}$ receptor signaling and inhibition of $D 2$ receptor signaling. A study of neuronal typespecific regulation of DARPP-32 phosphorylation at Thr34 using neostriatal slices showed that papaverine increased DARPP-32 phosphorylation by six-fold in indirect pathway neurons, whereas it increased DARPP-32 phosphorylation only by two-fold in direct pathway neurons indicating that effects of PDE10A inhibition predominate the indirect pathway (Bateup et al., 2008; Nishi et al., 2008). Recent electrophysiological results support this conclusion (Threlfell et al., 2009). More support is provided by recent behavioral studies published by different groups, however, these latter studies also show substantial D1 direct pathway effects of PDE10A-Is (Megens et al., 2014b; Megens et al., 2014a; Gentzel et al., 2015; Suzuki et al., 2016).

In vivo, PDE10A-Is are studied mostly for effects on spontaneous or stimulated behaviors providing evidence for predominant indirect pathway effects (similar to effects of D2 receptor blockers). This would include inhibition of spontaneous or stimulant-induced behavior, inhibition of conditioned avoidance behavior, reversal of stimulant-induced sensory gating deficits and preferential activity against apomorphine-induced climbing (Schmidt et al., 2008; Grauer et al., 2009; Kehler and Nielsen, 2011; Gresack et al., 2013; Megens et al., 2014b). However, concomitant D1 receptor stimulation causes reduced efficiency against behavioral stimulants, via direct pathway activation (Menniti et al., 2007; Sotty et al., 2009; Gresack et al., 2013; Megens et al., 2014b). D1 receptor stimulation is also responsible for the cognition-enhancing effects (Rodefer et al., 2005; Grauer et al., 2009) and socializing effects (Grauer et al., 2009) of PDE10A-Is. So indeed, there is compelling evidence for substantial direct pathway activation of PDE10A-Is. This latter notion is supported by recent work from Megens and coworkers in suppressed behavior via D1 receptor blockade, D2 receptor blockade or DA depletion (Megens et al., 2014a). Their results indicate that PDE10A-Is reverse behavioral suppression after D1 receptor blockade (hypolocomotion) via direct pathway activation (next to suppressing stimulant behavior via indirect pathway activation). These effects are indicative of substantial D1 agonistic effects of PDE10A-Is (next to their D2 antagonistic effects). Still, the main effects of PDE10A-Is are suggested to be exerted trough the indirect pathway. By this route PDE10A-IS can cause extrapyramidal side-effects, resembling D2 receptor blockers. The latter may explain why PDE10A-Is have not yet reached the market as antipsychotic treatment. This notion is supported by 
the recent failure of the Pfizer PDE10A-I MP-10 (or PF-02545920) in a Phase II clinical trial as antipsychotic treatment, where it showed no efficacy on positive and negative symptoms and produced motor side-effects (akathisia and dystonia) in patients with schizophrenia (DeMartinis et al., 2012).

Finally, in contrast to PDE4 inhibition by rolipram, PDE10A inhibition by papaverine showed no increases on TH phosphorylation at Ser40 (PKA site) suggesting no effects of PDE10A inhibitors on DA synthesis. Of note, only at high concentration papaverine did show an effect on TH phosphorylation. Also, results for papaverine should be confirmed by using the more potent PDE10A-Is TP-10 and MP10. Additionally, PDE10A inhibition showed no effects on DA metabolism (Nishi et al., 2008). Therefore, in contrast to PDE4, it is assumed that PDE10A does not play a major role at dopaminergic terminals.

\section{Implications and clinical overview of PDE10A-Is}

PDE10A is even more extensively studied in relation to the fronto-striatal circuits than the previously discussed PDE4 and PDE1B subtypes. Due to the hypothesis of a higher expression in indirect pathway neurons PDE10A-Is have received much attention as potential DA D2 antagonists and as such for their antipsychotic properties. Historically, positive symptoms in schizophrenia have been linked to overstimulation of DA receptors in the striatum (Baumeister and Francis, 2002), which is attenuated by (PDE10A inhibition-induced) DA D2 receptor antagonism. Because of the expected predominant effects in the indirect pathway PDE10A is also hypothesized as therapeutic target in Huntington's disease. Increases in CAMP are expected to drive CREB dependent signaling pathways, known to be dysregulated in Huntington's disease mouse models (Choi et al., 2009). In line, like rolipram, TP-10 was shown to be neuroprotective in the quinolinic acid model of Huntington's disease through CREB-mediated neuroprotection (Giampa et al., 2009a). In a follow-up study, PDE10A-I treatment of R6/2 mice showed significant delays in development of the motor deficits measured in this model accompanied by reduced striatal and cortical cell loss (Giampa et al., 2010). This was accompanied by increased CREB phosphorylation, suggesting that increased CAMP signaling in these brain regions could slow progression of neurodegeneration. Additionally, gene expression studies have implicated PDE10A and CAMP signaling as a therapeutic strategy for Huntington's disease (Hebb et al., 2004). Chronic treatment of wildtype mice with TP-10 resulted in an increase in gene expression of members of the, for Huntington's disease neuroprotective, ERK and PKA signaling pathways and an increase in ERK and MSK phosphorylation (Roze et al., 2008; Kleiman et al., 2011; Martin et al., 2011). Hypothetically, in Parkinson's disease PDE10A-Is could be used in the same way to treat DA agonist- or levodopa-induced dyskinesias. Chronic treatment with both classes of drugs 
leads to improvement in symptoms but causes unwanted side-effects. These unwanted symptoms are thought to be due to D1 receptor functional supersensitivity, abnormal cAMP signaling and enhanced ERK signaling (Bezard et al., 2001; Aubert et al., 2005; Santini et al., 2007). Cyclic nucleotide levels were found to be decreased in the brains of rats treated with a combination of levodopa and 6-OHDA (Giorgi et al., 2008). Consistent with this finding, treatment of levodopainduced dyskinesias with TP-10 reduced the severity of dyskinesias observed in 6-OHDA rats. In this way PDE10A-Is rescue decreases in cyclic nucleotide levels and prolong the use of levodopa (Wilson and Brandon, 2015).

Preclinical antipsychotic effects of PDE10A-Is may have initiated fronto-striatal disorder-related research, though lack of clinical efficacy and possible extrapyramidal side effects are hampering PDE10A-Is in reaching the market as antipsychotic treatment. An example of the latter is provided by the failure of the Phase II clinical trial of the Pfizer PDE10A-I MP-10 (or PF-02545920). MP-10 showed no efficacy and produced motor side-effects. Despite the serious challenges, there remains interest in PDE10A-Is as antipsychotic treatment. For instance, Takeda is currently recruiting participants for a clinical Phase II study to evaluate the efficacy, safety and tolerability of TAK-063 compared with placebo in treatment of acutely exacerbated schizophrenia. Efficacy was explained as determining whether cognitive impairment associated with schizophrenia would be attenuated (ClinicalTrials.gov Identifier: NCT02477020). Also, a Phase I study by Hoffmann-La Roche has just been completed in which the safety, tolerability and pharmacokinetics of RO5545965 in patients with schizophrenia on risperidone was tested (no results have been posted; ClinicalTrials.gov Identifier: NCT02019329). Of note, in 2012 Amgen started and terminated a Phase I study to assess the safety and tolerability of their PDE10-I AMG 579 following a single oral dose administration in healthy subjects and in patients with schizophrenia or stable schizoaffective disorder (ClinicalTrials.gov Identifier: NCT01568203).

A recent study found no difference in PDE10A mRNA expression between schizophrenia patients and comparison subjects in any of the brain regions studied (thalamus, caudate, putamen, nucleus accumbens, globus pallidus, and substantia nigra). This is the first in vivo assessment of PDE10A expression in patients with schizophrenia. However, this should not be interpreted as a case against developing PDE10A drugs in schizophrenia. The study of intracellular signaling pathways makes a persuasive case for how PDE10A inhibitors could influence the overall signaling in a therapeutic direction, regardless of whether there is an intrinsic change in PDE10A in schizophrenia (Marques et al., 2016). 
Pharmaceutical companies have also started to redesignate their PDE10-Is to Huntington's disease. A Phase II proof-of-concept trial is now being initiated in which Pfizer's PDE10A-I MP-10 will be tested for safety and efficacy in subjects with Huntington's disease (ClinicalTrials.gov Identifier: NCT02197130). Omeros initiated a Phase II clinical trial in Huntington's disease patients with OMS824 after an earlier Phase II trial in schizophrenia patients (no results disclosed; ClinicalTrials.gov Identifier: NCT01952132). The Huntington's disease trial is a sequential-cohort dose-escalation study that evaluates the safety and tolerability of OMS824 over four weeks (ClinicalTrials.gov Identifier: NCT02074410). In parallel with the clinical OMS824 trial, Omeros is conducting preclinical rat studies to support clinical trials of longer duration. However, based on that data, there might be a safety issue and based on follow-up communications with the FDA, Omeros has suspended the ongoing Huntington's disease trial. The FDA has requested that Omeros further evaluates the preclinical data in order to characterize the compound more fully prior to reinitiating the clinical trial (http://investor.omeros.com/phoenix.zhtml?c=219263\&p=irol-newsArticle Print\&ID=1979683).

Additional support for the use of PDE10-Is in Huntington's disease comes from a recent study which shows that PDE10 levels are lowered early before symptom onset in Huntington's disease (Niccolini et al., 2015b). Whether this is cause or consequence remains to be determined, however it most likely resembles a consequence of the degeneration of striatal cells and therefore the PDE10 enzymes within. These results were recently confirmed by a study with the radioligand [18F] MNI659A (Russell et al., 2016). A comparable large scale Phase 0 study is currently recruiting new participants. The aim of this study is to measure the availability of the PDE10A enzyme in Huntington's disease gene expansion carriers (HDGECS) using the recently developed radioligand [18F] MNI-659. The study will be cross-sectional, examining HDGECs at different stages of the disease (pre-manifest, stage 1 and stage 2), in comparison with healthy controls (ClinicalTrials.gov Identifier: NCT02061722).

Of note, Niccolini et al. also demonstrated striatal and pallidal loss of PDE10A expression in Parkinson's disease patients, which is associated with Parkinson's disease duration and severity of motor symptoms and complications (Niccolini et al., 2015a). These results suggest that dopaminergic nigrostriatal degeneration affects the expression of PDE10A in striatum and pallidum. Hypothesizing, it most likely resembles a compensatory mechanism. Less dopaminergic input from the SNc equals less CAMP activation in striatal and pallidal areas decreasing the required levels of PDE10. In another, more far-fetched scenario the decrease is causative. The decrease in PDE10 levels reflects the overall expression of PDE10 in these brain areas, not specified for the direct and indirect pathway. Because of the stronger expression of PDE10 in the indirect pathway compared to the direct pathway, PDE10 degeneration will affect the indirect pathway more strongly. Subsequently, reduced PDE10 
expression results in enhanced activation of the indirect pathway resulting in increased inhibition of movement. In both Parkinson's disease and Huntington's disease altered PDE10 levels are likely compensatory/consequential instead of causative. In hyperkinetic movement disorders like Huntington's disease, PDE10 may thus be a promising target for pharmacological agents (PDE10-Is enhance the little cAMP signaling that is left in the indirect pathway).

\section{Conclusion}

Clinical trials investigating the effects of PDE-Is in neuropsychiatric disorders are overall very sparse and the wealth of positive preclinical data could not yet be translated into clinical efficacy. As a result, no definitive conclusions can be drawn merely based on clinical trial outcomes. Therefore, the current review provides a discussion of the role of PDEs in dopaminergic frontal and striatal signaling and the potential of their associated inhibitors in specific disorders of the fronto-striatal circuits. Subsequently, an overview is provided of the current clinical status.

The fronto-striatal circuits compose the neurobiological basis for several neuropsychiatric disorders, including Parkinson's disease, Huntington's disease, ADHD, Tourette's syndrome, schizophrenia and obsessive-compulsive disorder. The fronto-striatal circuits constitute a plurality of parallel segregated circuits, which can be clustered together in motor circuits, associative/cognitive circuits and limbic circuits (Krack et al., 2010). Together, dysfunctions in these circuits produce the wide range of symptoms observed in related neuropsychiatric disorders.

Intracellularly, direct and indirect pathway signaling in the striatum is largely mediated through the cAMP/PKA cascade (Nishi et al., 2008; Nishi and Snyder, 2010; Nishi et al., 2011). Cyclic nucleotide cascades are involved in synaptic transmission, neuron excitability, neuroplasticity and neuroprotection in all types of fronto-striatal circuits (see figure 1). Additionally, all fronto-striatal circuits are modulated by dopamine. Next to the effects of CAMP/PKA pathways on glutamatergic and GABAergic signaling in the fronto-striatal circuits, these cyclic nucleotide pathways also play a major role in the dopaminergic modulation of the circuits. The intracellular effect of dopamine is mediated through dopamine receptor-regulated activation of CAMP/PKA and subsequent DARPP-32 and CREB phosphorylation in both striatal and frontal neurons.

In the last decades PDEs have therefore received increased attention for their possible role in disorders involving the fronto-striatal circuits. Based on overall expression patterns in frontal and striatal dopaminergic terminals, indirect pathway neurons and direct pathway neurons, PDE1B, PDE2A, PDE4, PDE7B, PDE9A and PDE10A seem to be the most interesting targets (Lakics et al., 2010), 
although most attention and resources have thus far been devoted to the potential of PDE1B, PDE4 and PDE10A due to their role in dopaminergic signaling. The main site of action and expression of PDE1B, PDE4 and PDE10A as discussed in this clinical review is inferred from biochemical analyses of striatal cAMP/PKA effectors, behavioral phenotypes of KO mice and the observation of effects of subtype-specific PDE-Is on dopamine-related behavior. The different PDE subtypes, and more specifically their splice-variants, can be related to different disorders due to their differential expression in one or more of the frontal and striatal pathways or dopaminergic terminals inducing stimulation of dopamine synthesis, the inhibtion of D2 receptor signaling or the stimulation of D1 receptor signaling. The different PDE isoforms contain a multiplicity of structural and biochemical properties and are located in specific subcellular compartments, with specific transcriptional and posttranscriptional regulation (Keravis and Lugnier, 2012). Therefore, expression of a PDE subtype in a brain area does not make it an interesting target per se. Their particular involvement in dopaminergic modulation of fronto-striatal signaling is what makes them an interesting target for related disorders. Preferably, the targeted cyclic nucleotide signaling cascade is involved in the pathology of the disorder or contributes to the reduction of the pathology. However, even if this is not the case, PDE inhibition could still influence the overall signaling in a therapeutic direction. Currently, researchers are just beginning to unravel the precise subcellular localization and the role of functional compartmentalization in physiological and pathological conditions of the fronto-striatal circuits (e.g. PDE10A: Russwurm et al., 2015; Li et al., 2016b; MacMullen et al., 2016). Another important consideration is that, in general, PDE-I research involving fronto-striatal disorders is based on the classical view of basal ganglia direct and indirect pathway functioning. Considerable evidence is congregating challenging this classical view (Cui et al., 2013; Calabresi et al., 2014; Keeler et al., 2014).

From a therapeutic perspective, inhibition of PDEs with increased expression appears most promising. This way, cognition and plasticity deficits resulting from impaired CAMP/PKA signaling might be improved by inhibiting specific PDE isoforms. However, PDE inhibition might have negative effects on cognition and plasticity when PDEs are already downregulated and cAMP levels and PKA activity are high. In this scenario, elevated CAMP levels might go over a physiological level and disrupt signaling. Along this line, high doses of rolipram impaired prefrontal cognitive function in aged, but not young monkeys, likely due to overstimulation of the already disinhibited cAMP/PKA signaling pathway in the aged prefrontal cortex (Ramos et al., 2003; Arnsten et al., 2005). This argues to specifically target PDEs that are overexpressed (see Table 2).

Table 2. Changes in human phosphodiesterase mRNA levels in several fronto-striatal disorders 


\begin{tabular}{|c|c|c|c|c|c|c|}
\hline & \multirow{2}{*}{$\begin{array}{l}\text { Schizophrenia } \\
\text { cerebellum }\end{array}$} & \multicolumn{2}{|c|}{ Parkinson's disease } & \multicolumn{3}{|c|}{ Huntington's disease } \\
\hline & & striatum & pallidum & striatum & pallidum & thalamus \\
\hline PDE1 & $\begin{array}{c}+ \\
(1 \mathrm{C})\end{array}$ & NS & NS & NS & NS & NS \\
\hline PDE2 & NS & NS & NS & NS & NS & NS \\
\hline PDE3 & NS & NS & NS & NS & NS & NS \\
\hline PDE4 & $\begin{array}{c}= \\
(4 \mathrm{~A} 1,4 \mathrm{~A} 5 \\
4 \mathrm{~A} 8) \\
- \\
(4 \mathrm{~B} 1,4 \mathrm{~B} 2,4 \mathrm{~B} 3, \\
4 \mathrm{~B} 4)\end{array}$ & NS & NS & NS & NS & NS \\
\hline PDE5 & NS & NS & NS & NS & NS & NS \\
\hline PDE6 & & & & & & \\
\hline PDE7 & NS & NS & NS & NS & NS & NS \\
\hline PDE8 & $\begin{array}{c}+ \\
(8 \mathrm{~B})\end{array}$ & NS & NS & NS & NS & NS \\
\hline PDE9 & NS & NS & NS & NS & NS & NS \\
\hline PDE10 & $\begin{array}{c}= \\
(10 \mathrm{~A})\end{array}$ & $\begin{array}{c}- \\
(10 A)\end{array}$ & $\begin{array}{c}- \\
(10 A)\end{array}$ & $\begin{array}{c}- \\
(10 \mathrm{~A})\end{array}$ & $\begin{array}{c}- \\
(10 A)\end{array}$ & $\begin{array}{c}+ \\
(10 \mathrm{~A})\end{array}$ \\
\hline PDE11 & NS & NS & NS & NS & NS & NS \\
\hline
\end{tabular}

+ increased, - decreased, = no change; NS not studied; (Fatemi et al., 2008a; Fatemi et al., 2008b; Fatemi et al., 2010; Marques et al., 2016; Niccolini et al., 2015a; Niccolini et al., 2015b; Russell et al., 2016)

In addition to the backbone formed by frontal neurons, MSNs and their dopaminergic modulation, the importance of interneurons in physiological and pathological fronto-striatal functioning is becoming increasingly apparent. Several types of interneurons can be found in the striatum, like cholinergic and different GABAergic interneurons (Gerfen and Surmeier, 2011). In particular, nitric oxide synthase (NOS) containing GABAergic interneurons we would like to highlight. These nitric oxide (NO)-producing interneurons play an important role in fronto-striatal functioning (West and Tseng, 2011). NO diffuses from these interneurons into dendrites of MSNs which contain high levels of guanylate cyclase (GC), which, when activated, lead to the synthesis of cGMP (see figure 1). In the intact striatum, transient elevations in intracellular cGMP primarily act to increase neuronal 
excitability and to facilitate glutamatergic fronto-striatal transmission (West and Tseng, 2011; Threlfell and West, 2013). Although the main focus in the fronto-striatal system has been on cAMP signaling, several PDE-Is (also) target cGMP (e.g. PDE1-Is and PDE10-Is) and may exert their effects (additionally) on the cGMP signaling cascade (Padovan-Neto et al., 2015).

Summarizing, increased understanding of the subcellular localization and unraveling of the signalosome concept of PDEs including its function and dysfunction in the fronto-striatal circuits will contribute to the design of new specific inhibitors and enhance the potential of PDE-Is as therapeutics in fronto-striatal circuits. 


\section{Acknowledgements}

PRAH is financially supported by the Human Enhancement and Learning (HEaL) initiative of Maastricht University.

\section{Statement of interest}

LW is an employee of Intra-Cellular Therapies, which has a financial interest in the PDE1 inhibitor ITI214. MAvD, AB and JP have a proprietary interest in the PDE4 inhibitor roflumilast. 


\section{References}

Alexander GE, Crutcher MD (1990) Functional architecture of basal ganglia circuits: neural substrates of parallel processing. Trends Neurosci 13:266-271.

Alexander GE, DeLong MR, Strick PL (1986) Parallel organization of functionally segregated circuits linking basal ganglia and cortex. Annu Rev Neurosci 9:357-381.

Alexander GE, Crutcher MD, DeLong MR (1990) Basal ganglia-thalamocortical circuits: parallel substrates for motor, oculomotor, "prefrontal" and "limbic" functions. Prog Brain Res 85:119146.

Arnsten AF (2013) The neurobiology of thought: the groundbreaking discoveries of Patricia GoldmanRakic 1937-2003. Cereb Cortex 23:2269-2281.

Arnsten AF, Pliszka SR (2011) Catecholamine influences on prefrontal cortical function: relevance to treatment of attention deficit/hyperactivity disorder and related disorders. Pharmacol Biochem Behav 99:211-216.

Arnsten AF, Ramos BP, Birnbaum SG, Taylor JR (2005) Protein kinase A as a therapeutic target for memory disorders: rationale and challenges. Trends Mol Med 11:121-128.

Aubert I, Guigoni C, Hakansson K, Li Q, Dovero S, Barthe N, Bioulac BH, Gross CE, Fisone G, Bloch B, Bezard E (2005) Increased D1 dopamine receptor signaling in levodopa-induced dyskinesia. Ann Neurol 57:17-26.

Bateup HS, Svenningsson P, Kuroiwa M, Gong S, Nishi A, Heintz N, Greengard P (2008) Cell typespecific regulation of DARPP-32 phosphorylation by psychostimulant and antipsychotic drugs. Nat Neurosci 11:932-939.

Baumeister AA, Francis JL (2002) Historical development of the dopamine hypothesis of schizophrenia. J Hist Neurosci 11:265-277.

Beaulieu JM, Gainetdinov RR (2011) The physiology, signaling, and pharmacology of dopamine receptors. Pharmacol Rev 63:182-217.

Becker A, Grecksch G (2008) Phosphodiesterase inhibitors--are they potential neuroleptic drugs? Behav Brain Res 186:155-160.

Belmaker RH, Ebstein RP, Biederman J, Stern R, Berman M, van Praag HM (1978) The effect of L-dopa and propranolol on human CSF cyclic nucleotides. Psychopharmacology (Berl) 58:307-310.

Bender AT, Beavo JA (2006) Cyclic nucleotide phosphodiesterases: molecular regulation to clinical use. Pharmacol Rev 58:488-520.

Bezard E, Brotchie JM, Gross CE (2001) Pathophysiology of levodopa-induced dyskinesia: potential for new therapies. Nat Rev Neurosci 2:577-588.

Bruel-Jungerman E, Davis S, Rampon C, Laroche S (2006) Long-term potentiation enhances neurogenesis in the adult dentate gyrus. J Neurosci 26:5888-5893.

Calabresi P, Picconi B, Tozzi A, Ghiglieri V, Di Filippo M (2014) Direct and indirect pathways of basal ganglia: a critical reappraisal. Nat Neurosci 17:1022-1030.

Calabresi P, Gubellini P, Centonze D, Picconi B, Bernardi G, Chergui K, Svenningsson P, Fienberg AA, Greengard P (2000) Dopamine and CAMP-regulated phosphoprotein $32 \mathrm{kDa}$ controls both striatal long-term depression and long-term potentiation, opposing forms of synaptic plasticity. J Neurosci 20:8443-8451.

Carew TJ, Sutton MA (2001) Molecular stepping stones in memory consolidation. Nat Neurosci 4:769771.

Casacchia M, Meco G, Castellana F, Bedini L, Cusimano G, Agnoli A (1983) Therapeutic use of a selective cAMP phosphodiesterase inhibitor (Rolipram) in Parkinson's disease. Pharmacol Res Commun 15:329-334.

Chauhan NB, Siegel GJ, Lee JM (2001) Depletion of glial cell line-derived neurotrophic factor in substantia nigra neurons of Parkinson's disease brain. J Chem Neuroanat 21:277-288.

Chen X, Xu L, Radcliffe P, Sun B, Tank AW (2008) Activation of tyrosine hydroxylase mRNA translation by cAMP in midbrain dopaminergic neurons. Mol Pharmacol 73:1816-1828. 
Cherry JA, Davis RL (1999) Cyclic AMP phosphodiesterases are localized in regions of the mouse brain associated with reinforcement, movement, and affect. J Comp Neurol 407:287-301.

Choi YS, Lee B, Cho HY, Reyes IB, Pu XA, Saido TC, Hoyt KR, Obrietan K (2009) CREB is a key regulator of striatal vulnerability in chemical and genetic models of Huntington's disease. Neurobiol Dis 36:259-268.

Cui G, Jun SB, Jin X, Pham MD, Vogel SS, Lovinger DM, Costa RM (2013) Concurrent activation of striatal direct and indirect pathways during action initiation. Nature 494:238-242.

D'Sa C, Tolbert LM, Conti M, Duman RS (2002) Regulation of cAMP-specific phosphodiesterases type $4 B$ and $4 D$ (PDE4) splice variants by cAMP signaling in primary cortical neurons. J Neurochem 81:745-757.

DeMarch Z, Giampa C, Patassini S, Bernardi G, Fusco FR (2008) Beneficial effects of rolipram in the R6/2 mouse model of Huntington's disease. Neurobiol Dis 30:375-387.

DeMarch Z, Giampa C, Patassini S, Martorana A, Bernardi G, Fusco FR (2007) Beneficial effects of rolipram in a quinolinic acid model of striatal excitotoxicity. Neurobiol Dis 25:266-273.

DeMartinis N, Banerjee A, Kumar V, Boyer S, Schmidt C, Arroyo S (2012) Poster \#212 RESULTS OF A PHASE 2A PROOF-OF-CONCEPT TRIAL WITH A PDE1OA INHIBITOR IN THE TREATMENT OF ACUTE EXACERBATION OF SCHIZOPHRENIA. Schizophr Res 136, Supplement 1:S262.

Dodge-Kafka KL, Soughayer J, Pare GC, Carlisle Michel JJ, Langeberg LK, Kapiloff MS, Scott JD (2005) The protein kinase A anchoring protein mAKAP coordinates two integrated cAMP effector pathways. Nature 437:574-578.

Duinen MV, Reneerkens OA, Lambrecht L, Sambeth A, Rutten BP, Os JV, Blokland A, Prickaerts J (2015) Treatment of Cognitive Impairment in Schizophrenia: Potential Value of Phosphodiesterase Inhibitors in Prefrontal Dysfunction. Curr Pharm Des 21:3813-3828.

Ehrman LA, Williams MT, Schaefer TL, Gudelsky GA, Reed TM, Fienberg AA, Greengard P, Vorhees CV (2006) Phosphodiesterase 1B differentially modulates the effects of methamphetamine on locomotor activity and spatial learning through DARPP32-dependent pathways: evidence from PDE1B-DARPP32 double-knockout mice. Genes Brain Behav 5:540-551.

Esposito K, Reierson GW, Luo HR, Wu GS, Licinio J, Wong ML (2009) Phosphodiesterase genes and antidepressant treatment response: a review. Ann Med 41:177-185.

Fatemi SH, Folsom TD, Reutiman TJ, Vazquez G (2010) Phosphodiesterase signaling system is disrupted in the cerebella of subjects with schizophrenia, bipolar disorder, and major depression. Schizophr Res 119:266-267.

Fatemi SH, King DP, Reutiman TJ, Folsom TD, Laurence JA, Lee S, Fan YT, Paciga SA, Conti M, Menniti FS (2008b) PDE4B polymorphisms and decreased PDE4B expression are associated with schizophrenia. Schizophr Res 101:36-49.

Fatemi SH, Reutiman TJ, Folsom TD, Lee S (2008a) Phosphodiesterase-4A expression is reduced in cerebella of patients with bipolar disorder. Psychiatr Genet 18:282-288.

Feng L, Wang CY, Jiang H, Oho C, Mizuno K, Dugich-Djordjevic M, Lu B (1999) Differential effects of GDNF and BDNF on cultured ventral mesencephalic neurons. Brain Res Mol Brain Res 66:6270.

Ferre S, Quiroz C, Orru M, Guitart X, Navarro G, Cortes A, Casado V, Canela El, Lluis C, Franco R (2011) Adenosine $A 2 A$ receptors and $A 2 A$ receptor heteromers as key players in striatal function. Front Neuroanat 5.

Fleischhacker WW, Hinterhuber H, Bauer H, Pflug B, Berner P, Simhandl C, Wolf R, Gerlach W, Jaklitsch $H$, Sastre-y-Hernandez M, et al. (1992) A multicenter double-blind study of three different doses of the new cAMP-phosphodiesterase inhibitor rolipram in patients with major depressive disorder. Neuropsychobiology 26:59-64.

Fusco FR, Giampa C (2015) Phosphodiesterases as therapeutic targets for Huntington's disease. Curr Pharm Des 21:365-377.

Gentzel RC, Toolan D, Roberts R, Koser AJ, Kandebo M, Hershey J, Renger JJ, Uslaner J, Smith SM (2015) The PDE10A inhibitor MP-10 and haloperidol produce distinct gene expression profiles in the striatum and influence cataleptic behavior in rodents. Neuropharmacology. 
Gerfen CR, Surmeier DJ (2011) Modulation of striatal projection systems by dopamine. Annu Rev Neurosci 34:441-466.

Gerfen CR, Engber TM, Mahan LC, Susel Z, Chase TN, Monsma FJ, Jr., Sibley DR (1990) D1 and D2 dopamine receptor-regulated gene expression of striatonigral and striatopallidal neurons. Science 250:1429-1432.

Giampa C, Laurenti D, Anzilotti S, Bernardi G, Menniti FS, Fusco FR (2010) Inhibition of the striatal specific phosphodiesterase PDE10A ameliorates striatal and cortical pathology in R6/2 mouse model of Huntington's disease. PLoS One 5:e13417.

Giampa C, Patassini S, Borreca A, Laurenti D, Marullo F, Bernardi G, Menniti FS, Fusco FR (2009a) Phosphodiesterase 10 inhibition reduces striatal excitotoxicity in the quinolinic acid model of Huntington's disease. Neurobiol Dis 34:450-456.

Giampa C, Middei S, Patassini S, Borreca A, Marullo F, Laurenti D, Bernardi G, Ammassari-Teule M, Fusco FR (2009b) Phosphodiesterase type IV inhibition prevents sequestration of CREB binding protein, protects striatal parvalbumin interneurons and rescues motor deficits in the R6/2 mouse model of Huntington's disease. Eur J Neurosci 29:902-910.

Gil JM, Rego AC (2008) Mechanisms of neurodegeneration in Huntington's disease. Eur J Neurosci 27:2803-2820.

Giorgi M, D'Angelo V, Esposito Z, Nuccetelli V, Sorge R, Martorana A, Stefani A, Bernardi G, Sancesario G (2008) Lowered cAMP and cGMP signalling in the brain during levodopainduced dyskinesias in hemiparkinsonian rats: new aspects in the pathogenetic mechanisms. Eur J Neurosci 28:941-950.

Grauer SM, Pulito VL, Navarra RL, Kelly MP, Kelley C, Graf R, Langen B, Logue S, Brennan J, Jiang L, Charych E, Egerland U, Liu F, Marquis KL, Malamas M, Hage T, Comery TA, Brandon NJ (2009) Phosphodiesterase 10A inhibitor activity in preclinical models of the positive, cognitive, and negative symptoms of schizophrenia. J Pharmacol Exp Ther 331:574-590.

Greengard P (2001) The neurobiology of dopamine signaling. Biosci Rep 21:247-269.

Greengard P, Allen PB, Nairn AC (1999) Beyond the dopamine receptor: the DARPP-32/protein phosphatase-1 cascade. Neuron 23:435-447.

Gresack JE, Seymour PA, Schmidt CJ, Risbrough VB (2013) Inhibition of phosphodiesterase 10A has differential effects on dopamine D1 and D2 receptor modulation of sensorimotor gating. Psychopharmacology (Berl).

Guan F, Zhang C, Wei S, Zhang H, Gong X, Feng J, Gao C, Su R, Yang H, Li S (2012) Association of PDE4B polymorphisms and schizophrenia in Northwestern Han Chinese. Hum Genet 131:1047-1056.

Gurney ME, Burgin AB, Magnusson OT, Stewart LJ (2011) Small molecule allosteric modulators of phosphodiesterase 4. Handb Exp Pharmacol:167-192.

Haber SN, Rauch SL (2010) Neurocircuitry: a window into the networks underlying neuropsychiatric disease. Neuropsychopharmacology 35:1-3.

Hannan AJ (2009) Towards a therapy for Huntington's disease (Commentary on Giampa et al.). Eur J Neurosci 29:901.

Harrison PJ, Weinberger DR (2005) Schizophrenia genes, gene expression, and neuropathology: on the matter of their convergence. Mol Psychiatry 10:40-68; image 45.

Hebb AL, Robertson HA (2008) PDEs as drug targets for CNS immune disorders. Curr Opin Investig Drugs 9:744-753.

Hebb AL, Robertson HA, Denovan-Wright EM (2004) Striatal phosphodiesterase mRNA and protein levels are reduced in Huntington's disease transgenic mice prior to the onset of motor symptoms. Neuroscience 123:967-981.

Heckman PR, Blokland A, Ramaekers J, Prickaerts J (2015) PDE and cognitive processing: beyond the memory domain. Neurobiol Learn Mem 119:108-122.

Houslay MD (1995) Compartmentalization of cyclic AMP phosphodiesterases, signalling 'crosstalk', desensitization and the phosphorylation of $\mathrm{Gi}-2$ add cell specific personalization to the control of the levels of the second messenger cyclic AMP. Adv Enzyme Regul 35:303-338. 
Houslay MD, Milligan G (1997) Tailoring cAMP-signalling responses through isoform multiplicity. Trends Biochem Sci 22:217-224.

Houslay MD, Adams DR (2003) PDE4 CAMP phosphodiesterases: modular enzymes that orchestrate signalling cross-talk, desensitization and compartmentalization. Biochem J 370:1-18.

Houslay MD, Baillie GS, Maurice DH (2007) CAMP-Specific phosphodiesterase-4 enzymes in the cardiovascular system: a molecular toolbox for generating compartmentalized cAMP signaling. Circ Res 100:950-966.

Howells DW, Porritt MJ, Wong JY, Batchelor PE, Kalnins R, Hughes AJ, Donnan GA (2000) Reduced BDNF mRNA expression in the Parkinson's disease substantia nigra. Exp Neurol 166:127-135.

Hulley P, Hartikka J, Lubbert H (1995a) Cyclic AMP promotes the survival of dopaminergic neurons in vitro and protects them from the toxic effects of MPP+. J Neural Transm Suppl 46:217-228.

Hulley P, Hartikka J, Abdel'Al S, Engels P, Buerki HR, Wiederhold KH, Muller T, Kelly P, Lowe D, Lubbert $H$ (1995b) Inhibitors of type IV phosphodiesterases reduce the toxicity of MPTP in substantia nigra neurons in vivo. Eur J Neurosci 7:2431-2440.

Hung HC, Lee EH (1996) The mesolimbic dopaminergic pathway is more resistant than the nigrostriatal dopaminergic pathway to MPTP and MPP+ toxicity: role of BDNF gene expression. Brain Res Mol Brain Res 41:14-26.

Hyman C, Hofer M, Barde YA, Juhasz M, Yancopoulos GD, Squinto SP, Lindsay RM (1991) BDNF is a neurotrophic factor for dopaminergic neurons of the substantia nigra. Nature 350:230-232.

Imanishi T, Sawa A, Ichimaru Y, Miyashiro M, Kato S, Yamamoto T, Ueki S (1997) Ameliorating effects of rolipram on experimentally induced impairments of learning and memory in rodents. Eur J Pharmacol 321:273-278.

Impey S, Mark M, Villacres EC, Poser S, Chavkin C, Storm DR (1996) Induction of CRE-mediated gene expression by stimuli that generate long-lasting LTP in area CA1 of the hippocampus. Neuron 16:973-982.

Izquierdo I, Bevilaqua LR, Rossato JI, Bonini JS, Medina JH, Cammarota M (2006) Different molecular cascades in different sites of the brain control memory consolidation. Trends Neurosci 29:496-505.

Jurevicius J, Fischmeister R (1996) CAMP compartmentation is responsible for a local activation of cardiac Ca2+ channels by beta-adrenergic agonists. Proc Natl Acad Sci U S A 93:295-299.

Keeler JF, Pretsell DO, Robbins TW (2014) Functional implications of dopamine D1 vs. D2 receptors: A 'prepare and select' model of the striatal direct vs. indirect pathways. Neuroscience 282C:156-175.

Kehler J, Nielsen J (2011) PDE10A inhibitors: novel therapeutic drugs for schizophrenia. Curr Pharm Des 17:137-150.

Keravis T, Lugnier C (2012) Cyclic nucleotide phosphodiesterase (PDE) isozymes as targets of the intracellular signalling network: benefits of PDE inhibitors in various diseases and perspectives for future therapeutic developments. Br J Pharmacol 165:1288-1305.

Kleiman RJ, Kimmel LH, Bove SE, Lanz TA, Harms JF, Romegialli A, Miller KS, Willis A, des Etages S, Kuhn M, Schmidt CJ (2011) Chronic suppression of phosphodiesterase 10A alters striatal expression of genes responsible for neurotransmitter synthesis, neurotransmission, and signaling pathways implicated in Huntington's disease. J Pharmacol Exp Ther 336:64-76.

Kotera J, Sasaki T, Kobayashi T, Fujishige K, Yamashita Y, Omori K (2004) Subcellular localization of cyclic nucleotide phosphodiesterase type $10 \mathrm{~A}$ variants, and alteration of the localization by cAMP-dependent protein kinase-dependent phosphorylation. J Biol Chem 279:4366-4375.

Krack P, Hariz MI, Baunez C, Guridi J, Obeso JA (2010) Deep brain stimulation: from neurology to psychiatry? Trends Neurosci 33:474-484.

Kritzer MD, Li J, Dodge-Kafka K, Kapiloff MS (2012) AKAPs: the architectural underpinnings of local cAMP signaling. J Mol Cell Cardiol 52:351-358.

Kumer SC, Vrana KE (1996) Intricate regulation of tyrosine hydroxylase activity and gene expression. J Neurochem 67:443-462. 
Kuroiwa M, Snyder GL, Shuto T, Fukuda A, Yanagawa Y, Benavides DR, Nairn AC, Bibb JA, Greengard P, Nishi A (2012) Phosphodiesterase 4 inhibition enhances the dopamine D1 receptor/PKA/DARPP-32 signaling cascade in frontal cortex. Psychopharmacology (Berl) 219:1065-1079.

Lakics V, Karran EH, Boess FG (2010) Quantitative comparison of phosphodiesterase mRNA distribution in human brain and peripheral tissues. Neuropharmacology 59:367-374.

Le Jeune IR, Shepherd M, Van Heeke G, Houslay MD, Hall IP (2002) Cyclic AMP-dependent transcriptional up-regulation of phosphodiesterase 4D5 in human airway smooth muscle cells. Identification and characterization of a novel PDE4D5 promoter. J Biol Chem 277:35980-35989.

Levivier M, Przedborski S, Bencsics C, Kang UJ (1995) Intrastriatal implantation of fibroblasts genetically engineered to produce brain-derived neurotrophic factor prevents degeneration of dopaminergic neurons in a rat model of Parkinson's disease. J Neurosci 15:7810-7820.

Li P, Zheng H, Zhao J, Zhang L, Yao W, Zhu H, Beard JD, Ida K, Lane W, Snell G, Sogabe S, Heyser CJ, Snyder GL, Hendrick JP, Vanover KE, Davis RE, Wennogle LP (2016a) Discovery of Potent and Selective Inhibitors of Phosphodiesterase 1 for the Treatment of Cognitive Impairment Associated with Neurodegenerative and Neuropsychiatric Diseases. J Med Chem 59:11491164.

Li YW, Seager MA, Wojcik T, Heman K, Molski TF, Fernandes A, Langdon S, Pendri A, Gerritz S, Tian Y, Hong Y, Gallagher L, Merritt JR, Zhang C, Westphal R, Zaczek R, Macor JE, Bronson JJ, Lodge NJ (2016b) Biochemical and behavioral effects of PDE10A inhibitors: Relationship to target site occupancy. Neuropharmacology 102:121-135.

Liemburg EJ, Knegtering H, Klein HC, Kortekaas R, Aleman A (2012) Antipsychotic medication and prefrontal cortex activation: a review of neuroimaging findings. Eur Neuropsychopharmacol 22:387-400.

Lu Y, Christian K, Lu B (2008) BDNF: a key regulator for protein synthesis-dependent LTP and longterm memory? Neurobiol Learn Mem 89:312-323.

Lu YF, Kandel ER, Hawkins RD (1999) Nitric oxide signaling contributes to late-phase LTP and CREB phosphorylation in the hippocampus. J Neurosci 19:10250-10261.

Luthi-Carter R, Strand A, Peters NL, Solano SM, Hollingsworth ZR, Menon AS, Frey AS, Spektor BS, Penney EB, Schilling G, Ross CA, Borchelt DR, Tapscott SJ, Young AB, Cha JH, Olson JM (2000) Decreased expression of striatal signaling genes in a mouse model of Huntington's disease. Hum Mol Genet 9:1259-1271.

MacMullen CM, Vick K, Pacifico R, Fallahi-Sichani M, Davis RL (2016) Novel, primate-specific PDE10A isoform highlights gene expression complexity in human striatum with implications on the molecular pathology of bipolar disorder. Translational psychiatry 6:e742.

Mantamadiotis $\mathrm{T}$, Lemberger $\mathrm{T}$, Bleckmann SC, Kern $\mathrm{H}$, Kretz $\mathrm{O}$, Martin Villalba A, Tronche $\mathrm{F}$, Kellendonk C, Gau D, Kapfhammer J, Otto C, Schmid W, Schutz G (2002) Disruption of CREB function in brain leads to neurodegeneration. Nat Genet 31:47-54.

Marques TR, Natesan S, Niccolini F, Politis M, Gunn RN, Searle GE, Howes O, Rabiner EA, Kapur S (2016) Phosphodiesterase 10A in Schizophrenia: A PET Study Using [C]IMA107. Am J Psychiatry:appiajp201515040518.

Martin E, Betuing S, Pages C, Cambon K, Auregan G, Deglon N, Roze E, Caboche J (2011) Mitogen- and stress-activated protein kinase 1-induced neuroprotection in Huntington's disease: role on chromatin remodeling at the PGC-1-alpha promoter. Hum Mol Genet 20:2422-2434.

Maurice DH (2011) Subcellular signaling in the endothelium: cyclic nucleotides take their place. Curr Opin Pharmacol 11:656-664.

Mayr B, Montminy M (2001) Transcriptional regulation by the phosphorylation-dependent factor CREB. Nat Rev Mol Cell Biol 2:599-609.

McCahill AC, Huston E, Li X, Houslay MD (2008) PDE4 associates with different scaffolding proteins: modulating interactions as treatment for certain diseases. Handb Exp Pharmacol:125-166. 
Medina AE (2011) Therapeutic utility of phosphodiesterase type I inhibitors in neurological conditions. Front Neurosci 5:21.

Megens AA, Hendrickx HM, Mahieu MM, Wellens AL, de Boer P, Vanhoof G (2014a) PDE10A inhibitors stimulate or suppress motor behavior dependent on the relative activation state of the direct and indirect striatal output pathways. Pharmacol Res Perspect 2:e00057.

Megens AA, Hendrickx HM, Hens KA, Fonteyn I, Langlois X, Lenaerts I, Somers MV, de Boer P, Vanhoof G (2014b) Pharmacology of JNJ-42314415, a centrally active phosphodiesterase 10A (PDE10A) inhibitor: a comparison of PDE10A inhibitors with D2 receptor blockers as potential antipsychotic drugs. J Pharmacol Exp Ther 349:138-154.

Menniti FS, Chappie TA, Humphrey JM, Schmidt CJ (2007) Phosphodiesterase 10A inhibitors: a novel approach to the treatment of the symptoms of schizophrenia. Curr Opin Investig Drugs 8:5459.

Millar JK, Wilson-Annan JC, Anderson S, Christie S, Taylor MS, Semple CA, Devon RS, St Clair DM, Muir WJ, Blackwood DH, Porteous DJ (2000) Disruption of two novel genes by a translocation cosegregating with schizophrenia. Hum Mol Genet 9:1415-1423.

Millar JK, Pickard BS, Mackie S, James R, Christie S, Buchanan SR, Malloy MP, Chubb JE, Huston E, Baillie GS, Thomson PA, Hill EV, Brandon NJ, Rain JC, Camargo LM, Whiting PJ, Houslay MD, Blackwood DH, Muir WJ, Porteous DJ (2005) DISC1 and PDE4B are interacting genetic factors in schizophrenia that regulate cAMP signaling. Science 310:1187-1191.

Minichiello L (2009) TrkB signalling pathways in LTP and learning. Nat Rev Neurosci 10:850-860.

Mogi M, Togari A, Kondo T, Mizuno Y, Komure O, Kuno S, Ichinose H, Nagatsu T (1999) Brain-derived growth factor and nerve growth factor concentrations are decreased in the substantia nigra in Parkinson's disease. Neurosci Lett 270:45-48.

Mohapel P, Frielingsdorf H, Haggblad J, Zachrisson O, Brundin P (2005) Platelet-derived growth factor (PDGF-BB) and brain-derived neurotrophic factor (BDNF) induce striatal neurogenesis in adult rats with 6-hydroxydopamine lesions. Neuroscience 132:767-776.

Mongillo M, Tocchetti CG, Terrin A, Lissandron V, Cheung YF, Dostmann WR, Pozzan T, Kass DA, Paolocci N, Houslay MD, Zaccolo M (2006) Compartmentalized phosphodiesterase-2 activity blunts beta-adrenergic cardiac inotropy via an NO/cGMP-dependent pathway. Circ Res 98:226-234.

Murdoch H, Mackie S, Collins DM, Hill EV, Bolger GB, Klussmann E, Porteous DJ, Millar JK, Houslay MD (2007) Isoform-selective susceptibility of DISC1/phosphodiesterase-4 complexes to dissociation by elevated intracellular cAMP levels. J Neurosci 27:9513-9524.

Nagel DJ, Aizawa T, Jeon KI, Liu W, Mohan A, Wei H, Miano JM, Florio VA, Gao P, Korshunov VA, Berk $B C$, Yan C (2006) Role of nuclear Ca2+/calmodulin-stimulated phosphodiesterase $1 \mathrm{~A}$ in vascular smooth muscle cell growth and survival. Circ Res 98:777-784.

Niccolini F, Foltynie T, Reis Marques T, Muhlert N, Tziortzi AC, Searle GE, Natesan S, Kapur S, Rabiner EA, Gunn RN, Piccini P, Politis M (2015a) Loss of phosphodiesterase 10A expression is associated with progression and severity in Parkinson's disease. Brain 138:3003-3015.

Niccolini F, Haider S, Reis Marques T, Muhlert N, Tziortzi AC, Searle GE, Natesan S, Piccini P, Kapur S, Rabiner EA, Gunn RN, Tabrizi SJ, Politis M (2015b) Altered PDE10A expression detectable early before symptomatic onset in Huntington's disease. Brain.

Nishi A, Snyder GL (2010) Advanced research on dopamine signaling to develop drugs for the treatment of mental disorders: biochemical and behavioral profiles of phosphodiesterase inhibition in dopaminergic neurotransmission. J Pharmacol Sci 114:6-16.

Nishi A, Kuroiwa M, Shuto T (2011) Mechanisms for the modulation of dopamine $d(1)$ receptor signaling in striatal neurons. Front Neuroanat 5:43.

Nishi A, Kuroiwa M, Miller DB, O'Callaghan JP, Bateup HS, Shuto T, Sotogaku N, Fukuda T, Heintz N, Greengard P, Snyder GL (2008) Distinct roles of PDE4 and PDE10A in the regulation of cAMP/PKA signaling in the striatum. J Neurosci 28:10460-10471.

Nishino N, Kitamura N, Hashimoto T, Tanaka C (1993) Transmembrane signalling systems in the brain of patients with Parkinson's disease. Rev Neurosci 4:213-222. 
Nucifora FC, Jr., Sasaki M, Peters MF, Huang H, Cooper JK, Yamada M, Takahashi H, Tsuji S, Troncoso J, Dawson VL, Dawson TM, Ross CA (2001) Interference by huntingtin and atrophin-1 with cbp-mediated transcription leading to cellular toxicity. Science 291:2423-2428.

Nunes F, Ferreira-Rosa K, Pereira Mdos S, Kubrusly RC, Manhaes AC, Abreu-Villaca Y, Filgueiras CC (2011) Acute administration of vinpocetine, a phosphodiesterase type 1 inhibitor, ameliorates hyperactivity in a mice model of fetal alcohol spectrum disorder. Drug Alcohol Depend 119:81-87.

Padovan-Neto FE, Sammut S, Chakroborty S, Dec AM, Threlfell S, Campbell PW, Mudrakola V, Harms JF, Schmidt CJ, West AR (2015) Facilitation of corticostriatal transmission following pharmacological inhibition of striatal phosphodiesterase 10A: role of nitric oxide-soluble guanylyl cyclase-cGMP signaling pathways. J Neurosci 35:5781-5791.

Parain K, Murer MG, Yan Q, Faucheux B, Agid Y, Hirsch E, Raisman-Vozari R (1999) Reduced expression of brain-derived neurotrophic factor protein in Parkinson's disease substantia nigra. Neuroreport 10:557-561.

Parkes JD, Thompson C, Brennan L, Gajraj N, Howcroft B, Ruiz J (1984) Rolipram in Parkinson's disease. Adv Neurol 40:563-565.

Pérez-Torres S, Miró X, Palacios JM, Cortés R, Puigdoménech P, Mengod G (2000) Phosphodiesterase type 4 isozymes expression in human brain examined by in situ hybridization histochemistry and $[3 \mathrm{H}]$ rolipram binding autoradiography: Comparison with monkey and rat brain. J Chem Neuroanat 20:349-374.

Pliszka SR (2005) The neuropsychopharmacology of attention-deficit/hyperactivity disorder. Biol Psychiatry 57:1385-1390.

Porritt MJ, Batchelor PE, Howells DW (2005) Inhibiting BDNF expression by antisense oligonucleotide infusion causes loss of nigral dopaminergic neurons. Exp Neurol 192:226-234.

Prickaerts J (2015) Phosphodiesterase Inhibitors. In: Encyclopedia of Psychopharmacology (Stolerman I, ed), pp 1306-1315: Springer Berlin Heidelberg.

Ramos BP, Birnbaum SG, Lindenmayer I, Newton SS, Duman RS, Arnsten AF (2003) Dysregulation of protein kinase a signaling in the aged prefrontal cortex: new strategy for treating age-related cognitive decline. Neuron 40:835-845.

Reed TM, Repaske DR, Snyder GL, Greengard P, Vorhees CV (2002) Phosphodiesterase 1B knock-out mice exhibit exaggerated locomotor hyperactivity and DARPP-32 phosphorylation in response to dopamine agonists and display impaired spatial learning. J Neurosci 22:51885197.

Richter W, Menniti FS, Zhang HT, Conti M (2013) PDE4 as a target for cognition enhancement. Expert Opin Ther Targets 17:1011-1027.

Rodefer JS, Murphy ER, Baxter MG (2005) PDE10A inhibition reverses subchronic PCP-induced deficits in attentional set-shifting in rats. Eur J Neurosci 21:1070-1076.

Rodriguez-Moreno A, Sihra TS (2013) Presynaptic kainate receptor-mediated facilitation of glutamate release involves Ca2+-calmodulin and PKA in cerebrocortical synaptosomes. FEBS Lett 587:788-792.

Roze E, Betuing S, Deyts C, Marcon E, Brami-Cherrier K, Pages C, Humbert S, Merienne K, Caboche J (2008) Mitogen- and stress-activated protein kinase-1 deficiency is involved in expandedhuntingtin-induced transcriptional dysregulation and striatal death. FASEB J 22:1083-1093.

Rubin CS (1994) A kinase anchor proteins and the intracellular targeting of signals carried by cyclic AMP. Biochim Biophys Acta 1224:467-479.

Russell DS, Jennings DL, Barret O, Tamagnan GD, Carroll VM, Caille F, Alagille D, Morley TJ, Papin C, Seibyl JP, Marek KL (2016) Change in PDE10 across early Huntington disease assessed by [18F]MNI-659 and PET imaging. Neurology 86:748-754.

Russwurm C, Koesling D, Russwurm M (2015) Phosphodiesterase 10A Is Tethered to a Synaptic Signaling Complex in Striatum. J Biol Chem 290:11936-11947. 
Rutten K, Misner DL, Works M, Blokland A, Novak TJ, Santarelli L, Wallace TL (2008) Enhanced longterm potentiation and impaired learning in phosphodiesterase 4D-knockout (PDE4D) mice. Eur J Neurosci 28:625-632.

Rutten K, Wallace TL, Works M, Prickaerts J, Blokland A, Novak TJ, Santarelli L, Misner DL (2011) Enhanced long-term depression and impaired reversal learning in phosphodiesterase 4Bknockout (PDE4B-/-) mice. Neuropharmacology 61:138-147.

Sachs NA, Sawa A, Holmes SE, Ross CA, DeLisi LE, Margolis RL (2005) A frameshift mutation in Disrupted in Schizophrenia 1 in an American family with schizophrenia and schizoaffective disorder. Mol Psychiatry 10:758-764.

Sagvolden T, Russell VA, Aase H, Johansen EB, Farshbaf M (2005) Rodent models of attentiondeficit/hyperactivity disorder. Biol Psychiatry 57:1239-1247.

Sakamoto K, Karelina K, Obrietan K (2011) CREB: a multifaceted regulator of neuronal plasticity and protection. J Neurochem 116:1-9.

Sancesario G, Giorgi M, D'Angelo V, Modica A, Martorana A, Morello M, Bengtson CP, Bernardi G (2004) Down-regulation of nitrergic transmission in the rat striatum after chronic nigrostriatal deafferentation. Eur J Neurosci 20:989-1000.

Sano H, Nagai Y, Miyakawa T, Shigemoto R, Yokoi M (2008) Increased social interaction in mice deficient of the striatal medium spiny neuron-specific phosphodiesterase 10A2. J Neurochem 105:546-556.

Santini E, Valjent E, Usiello A, Carta M, Borgkvist A, Girault JA, Herve D, Greengard P, Fisone G (2007) Critical involvement of CAMP/DARPP-32 and extracellular signal-regulated protein kinase signaling in L-DOPA-induced dyskinesia. J Neurosci 27:6995-7005.

Schmidt CJ, Chapin DS, Cianfrogna J, Corman ML, Hajos M, Harms JF, Hoffman WE, Lebel LA, McCarthy SA, Nelson FR, Proulx-LaFrance C, Majchrzak MJ, Ramirez AD, Schmidt K, Seymour PA, Siuciak JA, Tingley FD, 3rd, Williams RD, Verhoest PR, Menniti FS (2008) Preclinical characterization of selective phosphodiesterase 10A inhibitors: a new therapeutic approach to the treatment of schizophrenia. J Pharmacol Exp Ther 325:681-690.

Schoffelmeer AN, Wardeh G, Mulder AH (1985) Cyclic AMP facilitates the electrically evoked release of radiolabelled noradrenaline, dopamine and 5-hydroxytryptamine from rat brain slices. Naunyn Schmiedebergs Arch Pharmacol 330:74-76.

Scott Bitner R (2012) Cyclic AMP response element-binding protein (CREB) phosphorylation: a mechanistic marker in the development of memory enhancing Alzheimer's disease therapeutics. Biochem Pharmacol 83:705-714.

Shults CW, Kimber T, Altar CA (1995) BDNF attenuates the effects of intrastriatal injection of 6hydroxydopamine. Neuroreport 6:1109-1112.

Sibley DR, Monsma FJ, Jr., Shen Y (1993) Molecular neurobiology of dopaminergic receptors. Int Rev Neurobiol 35:391-415.

Siuciak JA (2008) The role of phosphodiesterases in schizophrenia : therapeutic implications. CNS Drugs 22:983-993.

Siuciak JA, McCarthy SA, Chapin DS, Reed TM, Vorhees CV, Repaske DR (2007) Behavioral and neurochemical characterization of mice deficient in the phosphodiesterase-1B (PDE1B) enzyme. Neuropharmacology 53:113-124.

Siuciak JA, Chapin DS, Harms JF, Lebel LA, McCarthy SA, Chambers L, Shrikhande A, Wong S, Menniti FS, Schmidt CJ (2006) Inhibition of the striatum-enriched phosphodiesterase PDE10A: a novel approach to the treatment of psychosis. Neuropharmacology 51:386-396.

Song RS, Massenburg B, Wenderski W, Jayaraman V, Thompson L, Neves SR (2013) ERK regulation of phosphodiesterase 4 enhances dopamine-stimulated AMPA receptor membrane insertion. Proc Natl Acad Sci U S A 110:15437-15442.

Sotty F, Montezinho LP, Steiniger-Brach B, Nielsen J (2009) Phosphodiesterase 10A inhibition modulates the sensitivity of the mesolimbic dopaminergic system to D-amphetamine: involvement of the D1-regulated feedback control of midbrain dopamine neurons. J Neurochem 109:766-775. 
Stangherlin A, Zaccolo M (2012) cGMP-cAMP interplay in cardiac myocytes: a local affair with farreaching consequences for heart function. Biochem Soc Trans 40:11-14.

Stangherlin A, Gesellchen F, Zoccarato A, Terrin A, Fields LA, Berrera M, Surdo NC, Craig MA, Smith G, Hamilton G, Zaccolo M (2011) cGMP signals modulate cAMP levels in a compartment-specific manner to regulate catecholamine-dependent signaling in cardiac myocytes. Circ Res 108:929-939.

Strange PG (1998) Pathology and drug action in schizophrenia: insights from molecular biology. Essays Biochem 33:105-116.

Strick CA, James LC, Fox CB, Seeger TF, Menniti FS, Schmidt CJ (2010) Alterations in gene regulation following inhibition of the striatum-enriched phosphodiesterase, PDE10A. Neuropharmacology 58:444-451.

Sun M, Kong L, Wang X, Lu XG, Gao Q, Geller Al (2005) Comparison of the capability of GDNF, BDNF, or both, to protect nigrostriatal neurons in a rat model of Parkinson's disease. Brain Res 1052:119-129.

Surmeier DJ, Carrillo-Reid L, Bargas J (2011) Dopaminergic modulation of striatal neurons, circuits, and assemblies. Neuroscience 198:3-18.

Surmeier DJ, Ding J, Day M, Wang Z, Shen W (2007) D1 and D2 dopamine-receptor modulation of striatal glutamatergic signaling in striatal medium spiny neurons. Trends Neurosci 30:228235.

Suzuki K, Harada A, Suzuki H, Miyamoto M, Kimura H (2016) TAK-063, a PDE10A Inhibitor with Balanced Activation of Direct and Indirect Pathways, Provides Potent Antipsychotic-Like Effects in Multiple Paradigms. Neuropsychopharmacology.

Svenningsson P, Nishi A, Fisone G, Girault JA, Nairn AC, Greengard P (2004) DARPP-32: an integrator of neurotransmission. Annu Rev Pharmacol Toxicol 44:269-296.

Threlfell S, West AR (2013) Review: Modulation of striatal neuron activity by cyclic nucleotide signaling and phosphodiesterase inhibition. Basal Ganglia 3:137-146.

Threlfell S, Sammut S, Menniti FS, Schmidt CJ, West AR (2009) Inhibition of Phosphodiesterase 10A Increases the Responsiveness of Striatal Projection Neurons to Cortical Stimulation. J Pharmacol Exp Ther 328:785-795.

Volicer L, Beal MF, Direnfeld LK, Marquis JK, Albert ML (1986) CSF cyclic nucleotides and somatostatin in Parkinson's disease. Neurology 36:89-92.

Walker FO (2007) Huntington's disease. Lancet 369:218-228.

Wennogle LP, Snyder G, Li P, Vanover K, Davis R, Fienberg A, Hendricks J, Mates S (2010) Enhancement of cognition in schizophrenia via inhibition of phosphodiesterase-1B and potentiation of dopamine D1 receptor signaling. Schizophrenia Res 117:489.

West AR, Tseng KY (2011) Nitric Oxide-Soluble Guanylyl Cyclase-Cyclic GMP Signaling in the Striatum: New Targets for the Treatment of Parkinson's Disease? Front Syst Neurosci 5:55.

Wilson LS, Brandon NJ (2015) Emerging biology of PDE10A. Curr Pharm Des 21:378-388.

Wilson LS, Baillie GS, Pritchard LM, Umana B, Terrin A, Zaccolo M, Houslay MD, Maurice DH (2011) A phosphodiesterase 3B-based signaling complex integrates exchange protein activated by cAMP 1 and phosphatidylinositol 3-kinase signals in human arterial endothelial cells. J Biol Chem 286:16285-16296.

Winterer G (2006) Cortical microcircuits in schizophrenia--the dopamine hypothesis revisited. Pharmacopsychiatry 39 Suppl 1:S68-71.

Winterer G, Weinberger DR (2004) Genes, dopamine and cortical signal-to-noise ratio in schizophrenia. Trends Neurosci 27:683-690.

Xie Z, Adamowicz WO, Eldred WD, Jakowski AB, Kleiman RJ, Morton DG, Stephenson DT, Strick CA, Williams RD, Menniti FS (2006) Cellular and subcellular localization of PDE10A, a striatumenriched phosphodiesterase. Neuroscience 139:597-607.

Yamashita N, Hayashi A, Baba J, Sawa A (1997a) Rolipram, a phosphodiesterase-4-selective inhibitor, promotes the survival of cultured rat dopaminergic neurons. Jpn J Pharmacol 75:155-159. 
Yamashita N, Miyashiro M, Baba J, Sawa A (1997b) Rolipram, a selective inhibitor of phosphodiesterase type 4, pronouncedly enhanced the forskolin-induced promotion of dopamine biosynthesis in primary cultured rat mesencephalic neurons. Jpn J Pharmacol 75:91-95.

Yang L, Calingasan NY, Lorenzo BJ, Beal MF (2008) Attenuation of MPTP neurotoxicity by rolipram, a specific inhibitor of phosphodiesterase IV. Exp Neurol 211:311-314.

Zaccolo M, De Giorgi F, Cho CY, Feng L, Knapp T, Negulescu PA, Taylor SS, Tsien RY, Pozzan T (2000) A genetically encoded, fluorescent indicator for cyclic AMP in living cells. Nat Cell Biol 2:25-29.

Zeller E, Stief HJ, Pflug B, Sastre-y-Hernandez M (1984) Results of a phase II study of the antidepressant effect of rolipram. Pharmacopsychiatry 17:188-190.

Zhang HT (2010) Phosphodiesterase Targets for Cognitive Dysfunction and Schizophrenia--a New York Academy of Sciences Meeting. IDrugs 13:166-168. 


\section{Chapter 4}

\section{Acute administration of roflumilast enhances sensory gating in healthy young humans in a randomized trial}

P.R.A. Heckman, M.A. Van Duinen, A. Blokland, T. Uz, J. Prickaerts and A. Sambeth

Submitted to Translational Psychiatry 


\begin{abstract}
Research has shown that the process of sensory gating is disrupted in patients suffering from clinical disorders including attention deficit hyperactivity disorder (ADHD), schizophrenia and Alzheimer's disease. Phosphodiesterase inhibitors (PDE-Is) have received an increased interest as a tool to improve cognitive performance in both animals and man. One of the cognitive areas investigated is sensory gating. Therefore, we investigated the effects of the PDE4-I roflumilast in a sensory gating paradigm in 20 healthy young human volunteers (age range 18 - 30 years). We applied a placebocontrolled randomized cross-over design and tested 3 doses $(100,300,1000 \mu \mathrm{g})$. The current study (ClinicalTrials.gov Identifier: NCT01433666) showed that roflumilast improved sensory gating in healthy young human volunteers only at the $100 \mu \mathrm{g}$ dose. This means roflumilast shows a beneficial effect on gating at a dose that had no adverse effects reported following single-dose administration. This indicates that roflumilast $100 \mu \mathrm{g}$ has a favorable side-effect profile. Roflumilast and PDE4 inhibition in general could therefore be seen as a promising treatment in disorders affected by disrupted sensory gating.
\end{abstract}




\section{Introduction}

Sensory gating is a process involved in early information processing which prevents overstimulation of higher cortical areas by filtering sensory information (Adler et al., 1998; Cromwell, Mears, Wan, \& Boutros, 2008; Freedman, Adler, Waldo, Pachtman, \& Franks, 1983). The typical sensory gating paradigm consists of two identical auditory stimuli that are presented with an interstimulus interval (ISI) between 0.5 and 2 seconds (s) and an intertrial interval (ITI) of at least $6 \mathrm{~s}$. The main principle is that the response to the second stimulus (S2) will be smaller than the response to the first stimulus (S1). The duration of the ISI is crucial and should not be shorter than $0.5 \mathrm{~s}$ or longer than $2 \mathrm{~s}$; else sensory gating will not be elicited. In humans the P50 (or P1; i.e. the response evoked $50 \mathrm{~ms}$ after stimulus onset) of the event-related potential (ERP) is believed to be the main component in the sensory gating paradigm. Although the P50 reflects information processing at early stages it has also been associated with different cognitive functions (Yadon, Bugg, Kisley, \& Davalos, 2009).

Human research has shown that the process of sensory gating is disrupted in patients suffering from clinical disorders including attention deficit hyperactivity disorder (ADHD), schizophrenia and Alzheimer's disease (Adler et al., 1982; Ally, Jones, Cole, \& Budson, 2006; Boutros, Belger, Campbell, D'Souza, \& Krystal, 1999; Cancelli et al., 2006; Green et al., 2015; Javitt, 2009; Jessen et al., 2001; Micoulaud-Franchi et al., 2015). The P50 has been suggested as a biomarker for the evaluation of drugs that may potentially have a beneficial effect on cognitive functions in schizophrenia (Javitt, Spencer, Thaker, Winterer, \& Hajos), but despite the prominent role that P50 abnormalities have played in our understanding of schizophrenia, more data is needed to fully incorporate P50 as clinical correlate (Potter, Summerfelt, Gold, \& Buchanan, 2006). For example, it has been shown that a nicotinic alpha-7 agonist improved cognition in schizophrenic patients and that this was associated with normalization in P50 deficits (Olincy et al., 2006; Zhang et al., 2012). One advantage of this EEGrelated measure is that it can be used for translational purposes (Blokland, Prickaerts, van Duinen, \& Sambeth, 2015; Drinkenburg, Ruigt, \& Ahnaou, 2015; Smucny, Stevens, Olincy, \& Tregellas, 2015).

The last decades, phosphodiesterase inhibitors (PDE-Is) have received an increasing interest as a tool to improve cognitive performance in both animals and man (Blokland, Menniti, \& Prickaerts, 2012; Gomez \& Breitenbucher, 2013; Maurice et al., 2014; Menniti, Faraci, \& Schmidt, 2006; Reneerkens, Rutten, Steinbusch, Blokland, \& Prickaerts, 2009; Richter, Menniti, Zhang, \& Conti, 2013; Wang, Zhang, Zhang, \& Li, 2015). As the initial focus of cognition enhancement was directed towards memory function, mainly in relation to Alzheimer's disease (for a review see Garcia-Osta, Cuadrado- 
Tejedor, Garcia-Barroso, Oyarzabal, \& Franco, 2012; Gurney, D'Amato, \& Burgin, 2015; Heckman, Wouters, \& Prickaerts, 2015), nowadays the relation between phosphodiesterases (PDEs) and cognitive processing is also investigated beyond the memory domain (e.g. Duinen et al., 2015; Heckman, Blokland, Ramaekers, \& Prickaerts, 2015; Heckman et al., 2016; Shim, Shuman, \& Duncan, 2016; Siuciak, 2008). One cognitive process in which PDE-Is might play a role is sensory gating (see Figure 1). 


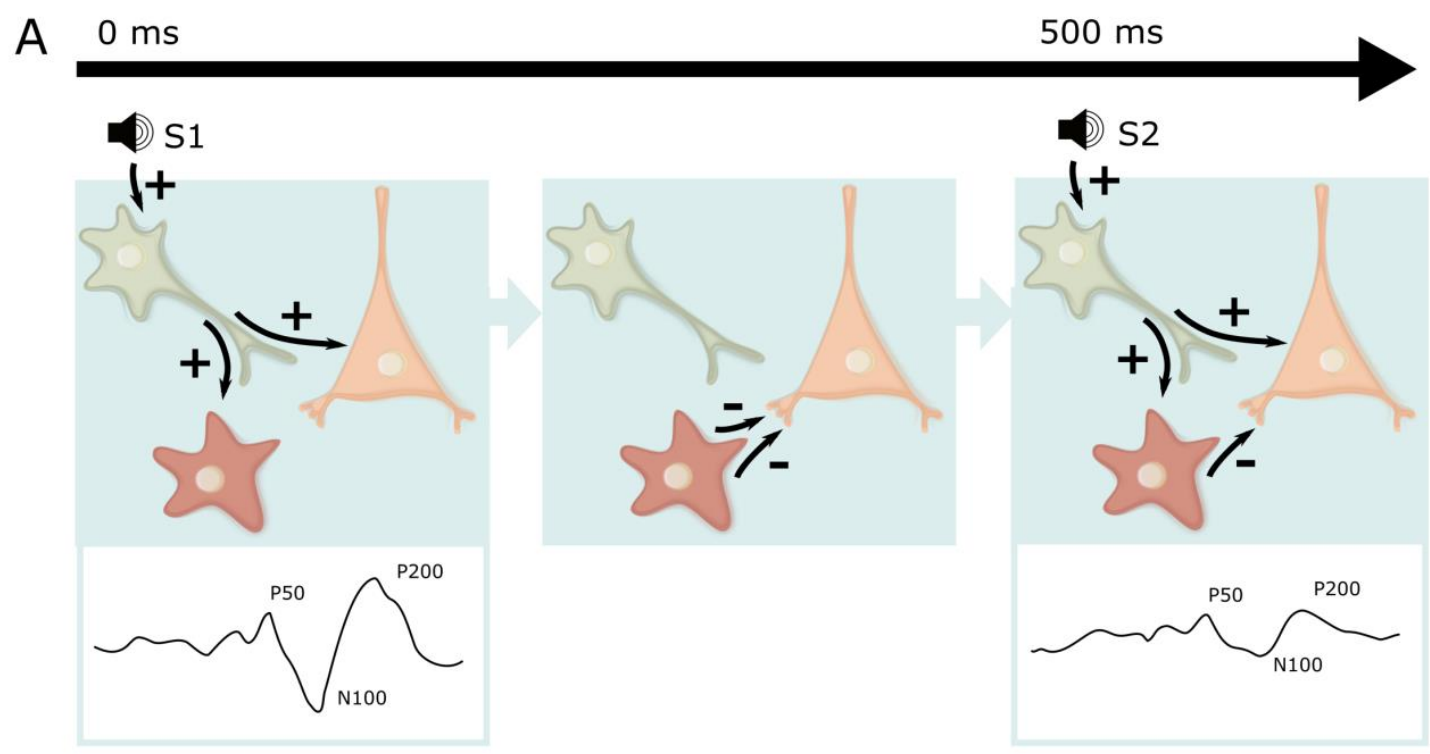

B
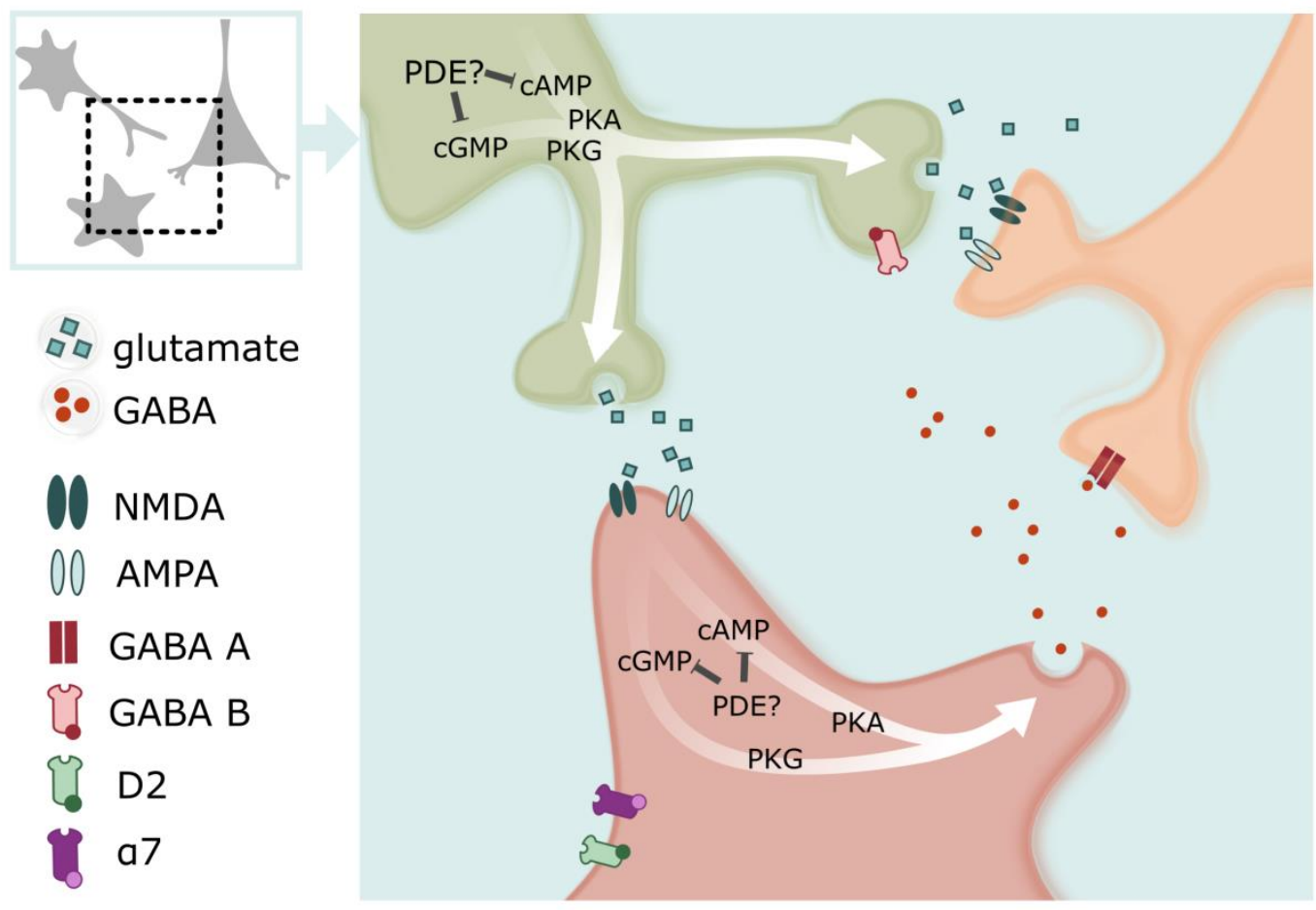

Fig. 1 Effects of PDE-Is on sensory gating are believed to be induced by targeting PDEs expressed in inhibitory interneurons of the auditory cortex and the thalamic 'gate', frontal inhibitory output neurons or in the interneurons that locally release inhibitory neurotransmitter in any other brain area capable of eliciting sensory gating. A) Auditory stimulus 1 (S1) excites an excitatory neuron, which in turn excites an inhibitory interneuron as well as an excitatory pyramidal neuron (left side figure). Activation of the inhibitory interneuron induces release of the inhibitory neurotransmitter GABA. GABA release causes fast inhibition of the pyramidal neuron 
via postsynaptic GABA-A receptors (middle figure). Additionally, GABA released from the inhibitory interneurons induces slow, persistent inhibition of glutamate release from the first excitatory neuron onto the pyramidal neuron via presynaptic GABA-B receptors. This persistent inhibition reduces the activity of the pyramidal neuron for up to $8 \mathrm{~s}$. Consequently, if S2 arrives the ERP amplitude will be reduced (right side figure). B) More detailed depiction of the processes explained in A), showing the release site of glutamate and GABA as well as the location of their respective receptors. The postsynaptic GABA-A receptor inhibits the pyramidal neuron after activation by S1. The presynaptic GABA-B receptor induces the persistent inhibition of the first excitatory neuron thereby inducing gating.

Targeting any PDE subtype, e.g. PDE4, expressed in the inhibitory interneuron itself could enhance GABA release from the inhibitory interneuron when activated by S1. Additionally, any PDE subtype, e.g. PDE4, expressed in the first excitatory neuron's projections to the inhibitory interneuron could also enhance GABA release in the inhibitory interneuron. Consequently, both will result in an enhanced reduction of the S2induced ERP amplitude. Note, however, that in the latter case, when the particular PDE subtype is expressed in the first excitatory neuron's projections to the inhibitory interneuron, this might also result in an enhanced response to S1. However, the latter is not observed in our study, indicating that the effect of roflumilast is more likely to occur in the inhibitory interneurons themselves.

Finally, the dopamine D2 receptor as well as the cholinergic $\alpha 7$ nicotinic receptor is depicted on the inhibitory interneuron. It is known from other studies that antipsychotic medication (D2 antagonists) enhances sensory gating. This possibly occurs via antagonism of the inhibitory effect D2 receptors exert on cAMP signaling and subsequent GABA release. In a similar but opposite manner, activating $\alpha 7$ nicotinic receptors on inhibitory interneurons enhances CAMP signaling in these neurons and increases associated GABA release.

Overall, only a limited number of human and animal studies have tested the effects of PDE-Is on sensory gating. Redrobe and colleagues (Redrobe et al., 2014), using the relatively new PDE2-I Lu AF64280, managed to induce an effect on sensory gating, i.e. reduction of an amphetamine-induced gating deficit in DBA2 mice. Both studies by Reneerkens et al. found no effects of either the PDE2-I BAY 60-7550 in rats, or the PDE5-I vardenafil in healthy rats as well as healthy young humans (in the absence of a deficit model)(Reneerkens, Sambeth, Blokland, \& Prickaerts, 2013; Reneerkens, Sambeth, Van Duinen, et al., 2013). Another class of PDE-Is tested in the sensory gating paradigm are PDE10A-Is. PDE10A-Is are chosen with respect to the search for new antipsychotics in the field of schizophrenia research due to the high and exclusive expression of PDE10A in the striatum (Lakics, Karran, \& Boess, 2010). Results for the PDE10A subclass of inhibitors are, however, mixed. On the one hand, no effects were found for the PDE10A-I PQ-10 in healthy rats (Reneerkens, Sambeth, Blokland, et al., 2013), an amphetamine-deficit model or a phencyclidine (PCP)-deficit model (Ahnaou, Biermans, \& Drinkenburg, 2016). On the other hand, TP-10, another more potent PDE10A-I, did reverse impaired sensory gating in the hippocampus using the amphetamine-induced deficit model in rats (Schmidt et al., 2008). 
The PDE9-Is PF-4447943 and PF-4449613 reversed an amphetamine-induced sensory gating deficit in mice (Kleiman et al., 2012). Additionally, PF-4447943 was tested in transgenic BACHD rats and Q175 mice (both transgenic animal models for Huntington's disease exhibiting impaired sensory gating) (Nagy, Tingley, Stoiljkovic, \& Hajos, 2015). PF-4447943 dose-dependently improved the gating deficit in the primary auditory cortex and hippocampus of transgenic BACHD rats. Daily administration of PF-04447943 (1 mg/kg) over 7-days resulted in a complete recovery in their auditory gating in both brain structures. In Q175 mice, including wild-type, heterozygote and homozygote mice, PDE9 inhibition was without any effect.

PDE4-Is were tested in the sensory gating paradigm in two separate studies. The first study tested the first-generation PDE4-I rolipram (Maxwell, Kanes, Abel, \& Siegel, 2004) and found that rolipram normalized the amphetamine-induced gating deficit in the hippocampus of mice. Another PDE4-I, RO-20-1724, (Halene \& Siegel, 2008) restored gating in the hippocampus of mice using an amphetamine-induced deficit model.

Because it can be argued that the ERPs of humans and rats show a significant amount of similarities, although the basic components of sensory gating may still differ between animals and humans (e.g. de Bruin et al., 2001), we expect that the effects of PDE-Is on sensory gating in animals translate to humans (Maxwell et al., 2004). Based on the few studies that are available, it appears that PDE4 is a promising PDE subtype followed by PDE9 and PDE10 (see Heckman, Blokland, et al., 2015). The PDE4I roflumilast was the first oral obtainable PDE4-I clinically approved at a daily dose of $500 \mu$ g, i.e. to treat chronic obstructive pulmonary disease (COPD). In the first clinical trials, roflumilast was able to improve lung function and to reduce the exacerbation of COPD, while the side effects consisted of very mild nausea, diarrhea and a light headache. Recently, we (Vanmierlo et al., 2016) and others (Jabaris et al., 2015) have shown that roflumilast is brain penetrant and improves short-term and long-term memory in rodents. Importantly, a PET study with the ligand [18F]B9302-107 for roflumilast confirmed that the currently marketed dose for COPD is also brain penetrant in humans (http://www.accessdata.fda.gov/drugsatfda docs/nda/2011/0225220rig1s000ClinPharmR.pdf, p. 150-151). On basis of these data, and the low emetic effects of roflumilast, this offered an excellent opportunity to investigate the cognitive effects of a PDE4-I in humans. Therefore, we investigated in the current study (ClinicalTrials.gov Identifier: NCT01433666) the acute effects of roflumilast in a sensory gating paradigm in healthy young human volunteers at three different doses, i.e. 100,300 and $1000 \mu \mathrm{g}$. We hypothesized roflumilast to enhance sensory gating in healthy young humans 
without exhibiting an effect on overall auditory processing as indicated by auditory evoked potentials (AEP).

\section{Methods}

\section{Participants}

All experimental procedures were approved by the independent Ethics Committee of Maastricht University and the Academic Hospital Maastricht (The Netherlands). The study was conducted according to the code of ethics on human experimentation established by the Declaration of Helsinki (1964) and amended in Edinburgh (2000) and in accordance with the Medical Research Involving Human Subjects Act (WMO). The participants (age range 18 - 35 years) were recruited through advertisements at Maastricht University between November 2011 and June 2012. Participants had to be willing to sign an informed consent form and were paid for their participation. The subjects' physical and mental health was checked by a physician by means of a standard medical questionnaire and a medical examination. Subjects were excluded if they suffered from or had a history of cardiac, hepatic, renal, pulmonary, neurological, gastrointestinal, hematological or psychiatric illness. Other exclusion criteria were excessive drinking ( >20 glasses of alcohol-containing beverages a week), pregnancy or lactation, use of medication other than oral contraceptives, use of recreational drugs from two weeks before, and until the end of, the experiment, and any sensory or motor deficit which could reasonably be expected to affect test performance. In addition, participants who had a firstdegree relative with a (history of) psychiatric disorder were excluded as well. The participants could leave the study at any given time without any consequences. In total 20 participants (mean age 20.9 \pm 2.3 years; 4 male/16 female) were included in the study.

\section{EEG recordings}

An EEG cap was used to place a set of 32 EEG electrodes according to the international 10-20 system (Klem, Luders, Jasper, \& Elger, 1999). Only the Fz, Fcz and Cz locations were used in the current study since it has been demonstrated previously that midline electrodes show better P50 sensory gating than left/right hemispheric sites (Wan, Crawford, \& Boutros, 2006). In addition, the Fz electrode has been demonstrated to show a similar amount of P200 gating and was therefore included as well (Wan, Crawford, \& Boutros, 2007). A reference and a ground were placed at the left mastoid and at the forehead, respectively. Eye movements were detected by horizontal and vertical electrooculogram (EOG) recordings. Before electrode attachment, the positions were slightly scrubbed with a gel in order to provide a good measurement. Both EEG and EOG were filtered between 0.01 and $100 \mathrm{~Hz}$ and sampled at $1000 \mathrm{~Hz}$. The sensory gating paradigm consisted of 60 pairs of identical auditory stimuli with a duration of $3 \mathrm{~ms}$ and intensity of $80 \mathrm{~dB}$. Since testing took place in a sound 
attenuated room with a maximal background noise level of $20 \mathrm{~dB}$, the stimulus salience was approximately $60 \mathrm{~dB}$. The interval between the first (S1) and the second (S2) stimulus was $500 \mathrm{~ms}$; the interval between pairs was randomized between 6 and $10 \mathrm{~s}$. The participants were familiarized with the test during a training session.

\section{Design and treatment}

The study was conducted according to a double-blind, placebo-controlled, four-way cross-over design. The current study was part of a larger project with the same ClinicalTrials.gov Identifier (NCT01433666), investigating the cognition enhancing effects of roflumilast. The treatment order was balanced over the four test days and separated by a washout period of at least 10 days. The balancing of the treatment order was accomplished by counterbalancing. Roflumilast $\mathrm{HCl}$ (Daxas) 500 $\mu \mathrm{g}$ tablets were grinded, and the appropriate quantities (i.e., 100, 300, $1000 \mu \mathrm{g}$ ) were distributed over capsules with lactose monohydrate as the principle constituent. The placebo capsules only contained lactose monohydrate in an equivalent amount and the appearance was identical to the roflumilast capsules. The capsules were manufactured, blinded, and labelled by Basic Pharma Technologies BV (Geleen, the Netherlands) according to GMP regulations. Randomization personnel (not otherwise involved in the study) generated the randomization schedule, which was provided to the contract packaging facility prior to the start of the study. All randomization information was stored in a secured area, accessible only by authorized personnel. Treatment on each of the four test days consisted of a single capsule containing either placebo, 100, 300 or $1000 \mu \mathrm{g}$ roflumilast. Previous studies have shown that peak plasma levels of roflumilast were reached $30-120 \mathrm{~min}$ (median, $60 \mathrm{~min}$ ) after a single dose of $500 \mu \mathrm{g}$ roflumilast; the terminal half-life was around $17 \mathrm{~h}$ for roflumilast and $30 \mathrm{~h}$ for its $\mathrm{N}$-oxide metabolite (Bethke et al., 2007). Since this study was part of a larger project comprising multiple cognitive tasks investigating several cognitive domains, our sensory gating paradigm was tested $90 \mathrm{~min}$ after drug treatment. The drugs were ingested orally and combined with a low-fat breakfast, because fatty food might affect the absorption of roflumilast. The experimenter and participants were blind to the compound and doses tested. All testing was conducted at the department of Neuropsychology and Psychopharmacology at Maastricht University.

\section{Questionnaire}

After each session the subjects were asked to fill in a questionnaire. Physical complaints were measured by a general list consisting of 31 items with a 4 point scale ranging from 0 : 'not at all' to 3 : 'strongly'. 
All EEG data was analyzed with Vision Analyzer 2.0 (Brain Products GmbH, Gilching, Germany). After offline re-referencing the signal combining the left and right mastoids, the EEG signal was filtered with a high-pass filter of $10 \mathrm{~Hz}$ and a low-pass filter of $40 \mathrm{~Hz}$. Next, eye movement artefacts were removed using the Gratton and Coles method (Gratton, Coles, \& Donchin, 1983). Segments between $100 \mathrm{~ms}$ before until $500 \mathrm{~ms}$ after stimulus onset were constructed for each stimulus type (S1 and S2) separately, using the last 100 ms before S1 onset as baseline for both stimuli. The segments were visually checked for artefacts and removed from the dataset if an artefact occurred during the first $500 \mathrm{~ms}$ after stimulus presentation. The grand average over participants was used to determine the AEP components. P50 was defined as most positive value between 65 and $110 \mathrm{~ms}$ after stimulus onset, N100 as most negative value between 90 and $170 \mathrm{~ms}$ and P200 as most positive value between 170 and $260 \mathrm{~ms}$. Due to violation of normality, data was analyzed using nonparametric tests for the amplitudes of the AEP component at the Fz, FCz and $\mathrm{Cz}$ locations (channels). First, outliers were removed from the raw data. Next, effects of roflumilast on basal information processing were evaluated by comparing treatment effects on auditory evoked potentials (S1). Subsequently, the responses to the S1 and S2 (S1-S2/S2) were compared by means of Wilcoxon Signed-ranks tests for the placebo condition to determine whether sensory gating occurred. To correct for variation in S2, relative gating scores were calculated (S1-S2/S2). Next, the responses to the roflumilast conditions were compared with the placebo condition for the scores by means of Wilcoxon Signed-ranks tests.

\section{Results}

\section{Physical Complaints}

After administration of $100 \mu \mathrm{g}$, the subjects did not report any physical complaint. At $300 \mu \mathrm{g}$ four subjects reported mild nausea, but no other complaints. After the highest dose mild nausea was reported by 3 subjects and 5 subjects reported a higher level of nausea. In addition, two subjects reported diarrhea at the highest dose.

\section{Effects of roflumilast on auditory evoked potentials (S1)}

No effects of PDE4 inhibition by roflumilast $(100 \mu \mathrm{g}, 300 \mu \mathrm{g}$ and $1000 \mu \mathrm{g})$ compared to placebo treatment were found with the Wilcoxon Signed-ranks test on the S1 or S2 stimulus for the P50 peak for neither the $\mathrm{Fz}$ channel nor the $\mathrm{FCz}$ and $\mathrm{Cz}$ channels (data not shown). Also, no effects were found on the two other ERP components (N100 and P200; data not shown).

\section{The sensory gating paradigm}

Effects of placebo treatment on sensory gating for the Fz electrode are depicted in figure 2. Analysis by means of a Wilcoxon Signed-ranks test for the three channels $\mathrm{Fz}, \mathrm{FCz}$ and $\mathrm{Cz}$ separately showed 
that gating occurred in all three channels for the P50 peak $(Z=-2.05, \mathrm{p}<.05 ; Z=-3.10, \mathrm{p}<.01 ; Z=-$ $2.91, p<.01)$. Additionally, sensory gating occurred for the N100 peak for all three channels $(Z=-$ 3.54, $\mathrm{p}<.001 ; Z=-3.88, \mathrm{p}<.001 ; Z=-3.85, \mathrm{p}<.001$ ) as well as for the P200 peak of all three channels $(Z=-3.68, \mathrm{p}<.001 ; Z=-3.92, \mathrm{p}<.001 ; Z=-3.82, \mathrm{p}<.001)$.

\section{Placebo data Fz}

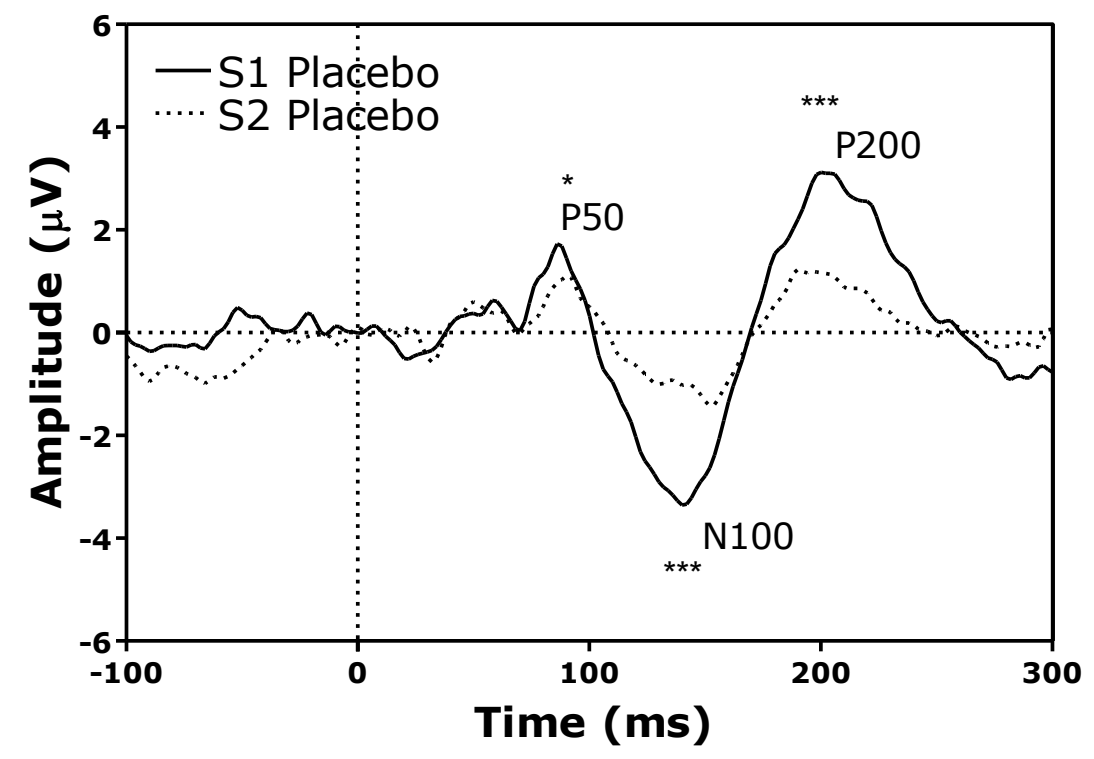

Fig. 2 Placebo ERPs (P50, N100 and P200 peaks) after presentation of S1 and S2. Sensory gating, i.e. a difference between S1 and S2, is depicted with asterisks (Wilcoxon Signed-ranks test: ${ }^{*} \mathrm{p}<.05$; $*_{* *} \mathrm{p}<.001$ ). Latencies are shown on the $x$-axis in milliseconds, amplitudes on the $y$-axis in microvolts.

\section{Effects of roflumilast on sensory gating}

The effect of roflumilast (100 $\mu \mathrm{g}, 300 \mu \mathrm{g}$ and $1000 \mu \mathrm{g}$ ) on sensory gating is shown in figure 3. A Wilcoxon Signed-ranks test indicated that sensory gating significantly improved at the Fz electrode for the P50 component after treatment with $100 \mu \mathrm{g}$ roflumilast compared to placebo, $Z=-2.01, \mathrm{p}<$ .05. No effects of roflumilast are found on the N100 or P200 ERP components of any of the channels. 


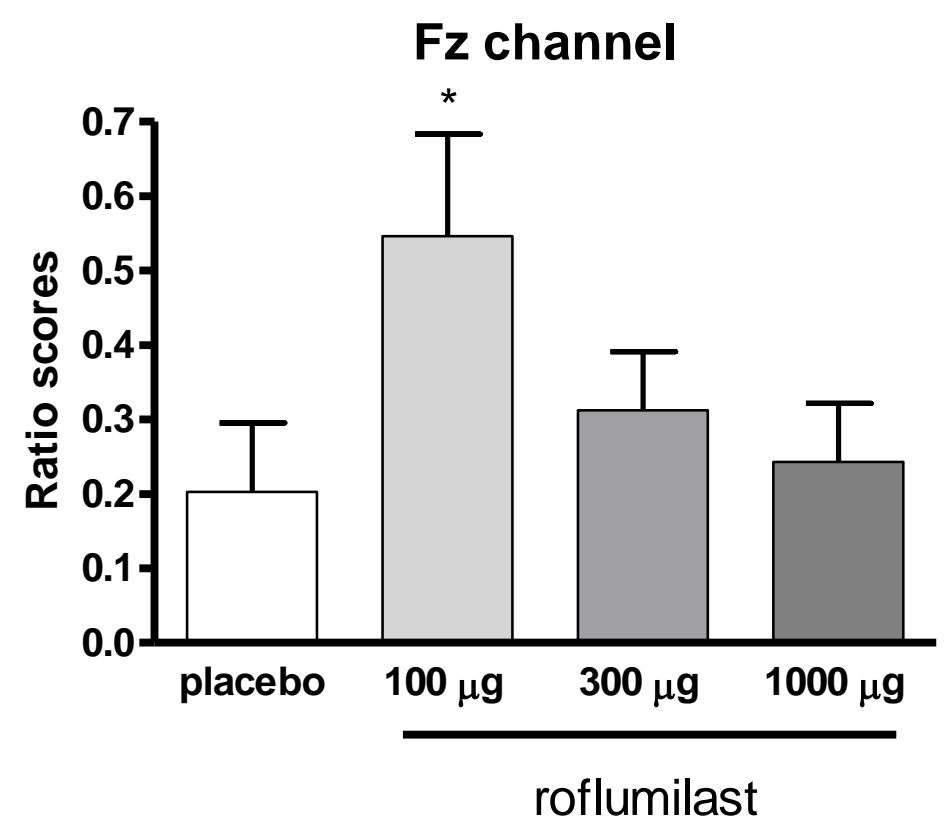

Fig. 3 Effects of treatment with the PDE4 inhibitor roflumilast on the mean relative gating score $( \pm S E M)$ of the P50 peak of the Fz channel. An effect on sensory gating, i.e. different gating score compared to placebo, is depicted with an asterisk (Wilcoxon Signed-ranks test: ${ }^{*} \mathrm{p}<.05$ ). Compounds/doses are depicted on the $\mathrm{x}$-axis; ratio scores are depicted on the y-axis (higher ratio scores indicate better sensory gating)

\section{Discussion}

In the current study we investigated whether the PDE4-I roflumilast could enhance sensory gating in a dose-dependent manner in healthy young human volunteers without exhibiting an effect on overall auditory processing as indicated by AEP. Results showed that roflumilast significantly improved sensory gating in healthy young human volunteers. The effect was induced in a dose-dependent manner. The effective dose of $100 \mu \mathrm{g}$ is 5 times lower than the clinically approved dose for the treatment of acute exacerbations in COPD. Notably, no emetic side effects were reported by the participants after administration of this low dose. This means roflumilast shows a beneficial effect on gating at a dose that had no adverse effects reported following single-dose administration in the present study. This indicates that roflumilast $100 \mu \mathrm{g}$ has a favorable side-effect profile. In the current study, the three doses of roflumilast administered resulted in plasma levels at the time of testing which could be expected based on PK studies measuring roflumilast, 2.09, 6.27 and $8.19 \mathrm{ng} / \mathrm{mL}$, respectively (Lahu, Nassr, \& Hunnemeyer, 2011). Most importantly, based on the present EEG data, it is clear that a dose of $100 \mu \mathrm{g}$ roflumilast is centrally active. 
As shortly mentioned before, a clear distinction should be made between effects on AEPs (S1) and effects on sensory gating, even though both are considered 'early information processing'. Different PDE families and their inhibitors can distinctively affect AEPs and sensory gating. Furthermore, whether sensory gating is expressed as a ratio score (e.g. S2/S1), difference score (e.g. S1-S2), proportional score (e.g. S1-S2/S2) or percentage score (e.g. (S1-S2/S2)*100), it always explains S2 in terms of S1. An effect on AEPs after S1 will also change the ratio between S1 and S2 which has to be taken into consideration when interpreting an effect on sensory gating. An effect on S1 indicates an effect on basic information processing. To induce a true effect on sensory gating, S1 should not be affected by the drug. A significant S2 effect (decreasing amplitude) would support drug effects on sensory gating though is not necessary, as long as the relative gating score is showing significant drug effects, i.e. there is a difference on this score between drug conditions. We found that S1 did not differ between the placebo and the $100 \mu \mathrm{g}$ roflumilast condition. We found that roflumilast did not affect S1 and that the S1-S2 ratio was enhanced after treatment with the $100 \mu \mathrm{g}$ dose. This indicates that roflumilast enhances P50 gating in young healthy volunteers.

Another point of attention regards the fact that in preclinical studies an amphetamine-induced deficit was reversed by a PDE4 inhibitor (Halene \& Siegel, 2008; Maxwell et al., 2004). This might be regulated by a very different mechanism compared to the mechanism involved in enhanced unimpaired sensory gating in healthy volunteers. In schizophrenia the dopamine hypothesis has been revised to postulate that positive symptoms, in particular, arise from hyperactivation of the dopaminergic D2 receptor subtype in mesolimbic brain regions (Brisch et al., 2014). Disruptive effects of amphetamine on sensory gating are suggested to be caused by hyperactive dopamine transmission resembling the dopamine hypothesis in schizophrenia (Smucny et al., 2015). The released dopamine will bind to the D2 receptors thereby inhibiting the inhibitory interneurons. Excess dopamine will thus lead to excessive throughput impairing normal gating. This hypothesis is supported by the fact that dopamine D2 receptor antagonists can prevent the amphetamine-induced deficits in sensory gating (During, Glenthoj, Andersen, \& Oranje, 2014; Freedman et al., 1987; Light et al., 1999; Witten et al., 2016). Dopamine D2 receptor antagonism prevents inhibition of inhibitory interneurons. Note, however, that in the field of schizophrenia research dopaminergic drugs generally show no gating enhancing effects, outside of the amphetamine-deficit model, in schizophrenia patients, healthy humans and animals, and animal models of schizophrenia other than the amphetamine-deficit model (Adler et al., 1990; Arango, Summerfelt, \& Buchanan, 2003; During et al., 2014; Freedman et al., 1983; Light et al., 1999; Oranje et al., 2004; Sanchez-Morla et al., 2009; Siegel et al., 2005; Simosky, Stevens, Adler, \& Freedman, 2003). Thus, so far D2 antagonism has not convincingly proven to be effective on sensory gating in healthy subjects (either animal or man; e.g. 
(Nagamoto et al., 1996). Therefore, reversal of the amphetamine-deficit model by PDE inhibition could be merely seen as proof of its additional antipsychotic potential resembling D2 antagonism.

Dopamine is not the only neurotransmitter that can affect sensory gating. In theory, any signaling system, combined or by itself, affecting downstream structures capable of exhibiting gating, can show effects in a sensory gating paradigm. Both noradrenaline (e.g. Adler et al., 1994; Witten et al., 2016) and acetylcholine (e.g. Adler, Hoffer, Wiser, \& Freedman, 1993; Adler, Hoffer, Griffith, Waldo, \& Freedman, 1992; Adler et al., 2001; Adler et al., 1998) have been shown to affect sensory gating. Especially, the cholinergic system is of interest as a treatment for gating deficits in schizophrenia as the inhibitory interneurons contain, next to the dopamine D2 receptors, $\alpha 7$ nicotinic acetylcholine receptors which upon activation stimulate GABA ( $\gamma$-aminobutyric acid) release (Albuquerque, Pereira, Braga, Matsubayashi, \& Alkondon, 1998; Frazier et al., 1998; Young \& Geyer, 2013)(see Figure 1). In theory, PDEs expressed in any neuron modulating the inhibitory interneuron, like the dopaminergic and cholinergic projections, could modulate sensory gating.

Our results with roflumilast are thus not easily explained by the neurobiological mechanisms underlying sensory gating. In general, effects of PDE-Is on sensory gating are believed to be induced by targeting PDEs expressed in inhibitory interneurons of the auditory cortex and the thalamic 'gate', frontal inhibitory output neurons or in the interneurons that locally release inhibitory neurotransmitter in any other brain area capable of eliciting sensory gating. More simplified, in the above mentioned brain areas, S1 excites an excitatory neuron, which in turn excites an inhibitory interneuron as well as an excitatory pyramidal neuron (Smucny et al., 2015)(see figure 1). Activation of the inhibitory interneuron induces release of the inhibitory neurotransmitter GABA. GABA release causes fast inhibition of the pyramidal neuron via postsynaptic GABA-A receptors. Additionally, GABA released from the inhibitory interneurons induces slow, persistent inhibition of glutamate release from the first excitatory neuron onto the pyramidal neuron via presynaptic GABA-B receptors (Hershman, Freedman, \& Bickford, 1995). This persistent inhibition reduces the activity of the pyramidal neuron for up to $8 \mathrm{~s}$. Consequently, if S2 arrives the ERP amplitude will be reduced.

Hypothetically, targeting any PDE subtype, e.g. PDE4, expressed in the first excitatory neuron's projections to the inhibitory interneuron as well as PDEs expressed in the inhibitory interneuron itself could enhance output of both neurons when activated by S1. Consequently, the S2-induced ERP amplitude will be further reduced. Note, however, that PDEs expressed in the first excitatory neuron's projections directly to the pyramidal neuron must not be enhanced since this would increase the response to S1 and therefore positively affect general auditory information processing. 
Roflumilast enhances sensory gating without exhibiting an effect on S1. Therefore, the effect of roflumilast is more likely to occur in the inhibitory interneurons themselves. PDE4 is indeed relatively highly expressed in brain areas associated with the neurobiology of sensory gating (Lakics et al., 2010). However, due to the extended neurobiology of sensory gating and the potential expression of PDE subfamilies within the brain areas involved, it is conceivable that inhibition of more than one subtype of PDE could enhance sensory gating (potentially accounting for the aforementioned positive effects of PDE9-Is and PDE10-Is).

Additionally, PDE4-Is may function like dopamine D2 receptor antagonists although it needs to be determined whether this is directly beneficial for sensory gating. Taken together, future preclinical studies will have to provide more insight into the mechanism by which PDE4 inhibition enhances sensory gating in healthy and pharmacologically-impaired volunteers, and eventually patients. Of note, when comparing results several translational considerations should be taken into account, like site of measurement (local in rodents vs superficial in humans), mental state (anesthetized in rodents vs awake in rodents or humans), treatment duration (acute vs chronic) and route of drug administration (mostly intraperitoneal/subcutaneous in rodents vs mostly oral in humans), but also differences in PDE4 expression and pharmacokinetic properties of the drug (cf. Blokland, van Goethem, Heckman, Schreiber, \& Prickaerts, 2014).

Due to the positive effects of roflumilast on sensory gating observed in the current study the compound seems to be a promising treatment to test in disorders affected by disrupted sensory gating, like schizophrenia, Alzheimer's disease and ADHD. Additional support for roflumilast in these disorders is provided by recent studies that showed roflumilast to induce memory enhancing effects in rodents (Jabaris et al., 2015; Vanmierlo et al., 2016). In this study effects are exerted at the same low acute dose of roflumilast, thereby minimizing emetic adverse events. A low dose of roflumilast might therefore be seen as a promising treatment for cognitive symptoms in ADHD, schizophrenia and Alzheimer's disease. 


\section{Acknowledgements}

PRAH is financially supported by the Human Enhancement and Learning (HEaL) initiative of Maastricht University.

This project was financed by The Netherlands Organization for Health Research and Development (ZonMW; project number 95110091).

We like to thank Dr. Eva P.P. Bollen for providing us with figure 1 of the manuscript.

\section{Statement of interest}

TU is an employee of Takeda Development Center Americas. MAvD, AB, JP and AS have a proprietary interest in the PDE4 inhibitor roflumilast. 


\section{References}

Adler, L. E., Gerhardt, G. A., Franks, R., Baker, N., Nagamoto, H., Drebing, C., \& Freedman, R. (1990). Sensory physiology and catecholamines in schizophrenia and mania. Psychiatry Research, 31(3), 297-309.

Adler, L. E., Hoffer, L., Nagamoto, H. T., Waldo, M. C., Kisley, M. A., \& Giffith, J. M. (1994). Yohimbine impairs P50 auditory sensory gating in normal subjects. Neuropsychopharmacology, 10(4), 249-257. doi: $10.1038 / n p p .1994 .28$

Adler, L. E., Hoffer, L. D., Wiser, A., \& Freedman, R. (1993). Normalization of auditory physiology by cigarette smoking in schizophrenic patients. American Journal of Psychiatry, 150(12), 18561861.

Adler, L. E., Hoffer, L. J., Griffith, J., Waldo, M. C., \& Freedman, R. (1992). Normalization by nicotine of deficient auditory sensory gating in the relatives of schizophrenics. Biological Psychiatry, 32(7), 607-616.

Adler, L. E., Olincy, A., Cawthra, E., Hoffer, M., Nagamoto, H. T., Amass, L., \& Freedman, R. (2001). Reversal of diminished inhibitory sensory gating in cocaine addicts by a nicotinic cholinergic mechanism. Neuropsychopharmacology, 24(6), 671-679. doi: 10.1016/s0893-133x(00)002426

Adler, L. E., Olincy, A., Waldo, M., Harris, J. G., Griffith, J., Stevens, K., . . Freedman, R. (1998). Schizophrenia, sensory gating, and nicotinic receptors. Schizophrenia Bulletin, 24(2), 189-202.

Adler, L. E., Pachtman, E., Franks, R. D., Pecevich, M., Waldo, M. C., \& Freedman, R. (1982). Neurophysiological evidence for a defect in neuronal mechanisms involved in sensory gating in schizophrenia. Biological Psychiatry, 17(6), 639-654.

Ahnaou, A., Biermans, R., \& Drinkenburg, W. H. (2016). Modulation of mGlu2 Receptors, but Not PDE10A Inhibition Normalizes Pharmacologically-Induced Deviance in Auditory Evoked Potentials and Oscillations in Conscious Rats. PloS One, 11(1), e0147365. doi: 10.1371/journal.pone. 0147365

Albuquerque, E. X., Pereira, E. F., Braga, M. F., Matsubayashi, H., \& Alkondon, M. (1998). Neuronal nicotinic receptors modulate synaptic function in the hippocampus and are sensitive to blockade by the convulsant strychnine and by the anti-Parkinson drug amantadine. Toxicology Letters, 102-103, 211-218.

Ally, B. A., Jones, G. E., Cole, J. A., \& Budson, A. E. (2006). Sensory gating in patients with Alzheimer's disease and their biological children. American Journal of Alzheimer's Disease and Other Dementias, 21(6), 439-447. doi: 10.1177/1533317506292282

Arango, C., Summerfelt, A., \& Buchanan, R. W. (2003). Olanzapine effects on auditory sensory gating in schizophrenia. American Journal of Psychiatry, 160(11), 2066-2068. doi: 10.1176/appi.ajp.160.11.2066

Bethke, T. D., Bohmer, G. M., Hermann, R., Hauns, B., Fux, R., Morike, K., . . Gleiter, C. H. (2007). Dose-proportional intraindividual single- and repeated-dose pharmacokinetics of roflumilast, an oral, once-daily phosphodiesterase 4 inhibitor. Journal of Clinical Pharmacology, 47(1), 2636. doi: $10.1177 / 0091270006294529$

Blokland, A., Menniti, F. S., \& Prickaerts, J. (2012). PDE inhibition and cognition enhancement. Expert Opinion on Therapeutic Patents, 22(4), 349-354. doi: 10.1517/13543776.2012.674514

Blokland, A., Prickaerts, J., van Duinen, M., \& Sambeth, A. (2015). The use of EEG parameters as predictors of drug effects on cognition. European Journal of Pharmacology, 759, 163-168. doi: 10.1016/j.ejphar.2015.03.031

Blokland, A., van Goethem, N., Heckman, P., Schreiber, R., \& Prickaerts, J. (2014). Translational issues with the development of cognition enhancing drugs. Frontiers in Neurology, 5, 190. doi: 10.3389/fneur.2014.00190

Boutros, N. N., Belger, A., Campbell, D., D'Souza, C., \& Krystal, J. (1999). Comparison of four components of sensory gating in schizophrenia and normal subjects: a preliminary report. Psychiatry Research, 88(2), 119-130.

Brisch, R., Saniotis, A., Wolf, R., Bielau, H., Bernstein, H. G., Steiner, J., . . Gos, T. (2014). The role of dopamine in schizophrenia from a neurobiological and evolutionary perspective: old fashioned, but still in vogue. Front Psychiatry, 5, 47. doi: 10.3389/fpsyt.2014.00047 
Cancelli, I., Cadore, I. P., Merlino, G., Valentinis, L., Moratti, U., Bergonzi, P., . . Valente, M. (2006). Sensory gating deficit assessed by $\mathrm{P} 50 / \mathrm{Pb}$ middle latency event related potential in Alzheimer's disease. Journal of Clinical Neurophysiology, 23(5), 421-425. doi: 10.1097/01.wnp.0000218991.99714.ee

Cromwell, H. C., Mears, R. P., Wan, L., \& Boutros, N. N. (2008). Sensory gating: a translational effort from basic to clinical science. Clinical EEG and Neuroscience, 39(2), 69-72.

de Bruin, N. M., Ellenbroek, B. A., van Schaijk, W. J., Cools, A. R., Coenen, A. M., \& van Luijtelaar, E. L. (2001). Sensory gating of auditory evoked potentials in rats: effects of repetitive stimulation and the interstimulus interval. Biological Psychology, 55(3), 195-213.

Drinkenburg, W. H., Ruigt, G. S., \& Ahnaou, A. (2015). Pharmaco-EEG Studies in Animals: An Overview of Contemporary Translational Applications. Neuropsychobiology, 72(3-4), 151-164. doi: 10.1159/000442210

Duinen, M. V., Reneerkens, O. A., Lambrecht, L., Sambeth, A., Rutten, B. P., Os, J. V., . . Prickaerts, J. (2015). Treatment of Cognitive Impairment in Schizophrenia: Potential Value of Phosphodiesterase Inhibitors in Prefrontal Dysfunction. Current Pharmaceutical Design, 21(26), 3813-3828.

During, S., Glenthoj, B. Y., Andersen, G. S., \& Oranje, B. (2014). Effects of dopamine D2/D3 blockade on human sensory and sensorimotor gating in initially antipsychotic-naive, first-episode schizophrenia patients. Neuropsychopharmacology, 39(13), 3000-3008. doi: 10.1038/npp.2014.152

Frazier, C. J., Rollins, Y. D., Breese, C. R., Leonard, S., Freedman, R., \& Dunwiddie, T. V. (1998). Acetylcholine activates an alpha-bungarotoxin-sensitive nicotinic current in rat hippocampal interneurons, but not pyramidal cells. Journal of Neuroscience, 18(4), 1187-1195.

Freedman, R., Adler, L. E., Gerhardt, G. A., Waldo, M., Baker, N., Rose, G. M., . . Franks, R. (1987). Neurobiological studies of sensory gating in schizophrenia. Schizophrenia Bulletin, 13(4), 669678.

Freedman, R., Adler, L. E., Waldo, M. C., Pachtman, E., \& Franks, R. D. (1983). Neurophysiological evidence for a defect in inhibitory pathways in schizophrenia: comparison of medicated and drug-free patients. Biological Psychiatry, 18(5), 537-551.

Garcia-Osta, A., Cuadrado-Tejedor, M., Garcia-Barroso, C., Oyarzabal, J., \& Franco, R. (2012). Phosphodiesterases as therapeutic targets for Alzheimer's disease. ACS Chemical Neuroscience, 3(11), 832-844. doi: 10.1021/cn3000907

Gomez, L., \& Breitenbucher, J. G. (2013). PDE2 inhibition: Potential for the treatment of cognitive disorders. Bioorganic and Medicinal Chemistry Letters. doi: 10.1016/j.bmcl.2013.10.014

Gratton, G., Coles, M. G., \& Donchin, E. (1983). A new method for off-line removal of ocular artifact. Electroencephalography and Clinical Neurophysiology, 55(4), 468-484.

Green, D. L., Payne, L., Polikar, R., Moberg, P. J., Wolk, D. A., \& Kounios, J. (2015). P50: A candidate ERP biomarker of prodromal Alzheimer's disease. Brain Research, 1624, 390-397. doi: 10.1016/j.brainres.2015.07.054

Gurney, M. E., D'Amato, E. C., \& Burgin, A. B. (2015). Phosphodiesterase-4 (PDE4) molecular pharmacology and Alzheimer's disease. Neurotherapeutics, 12(1), 49-56. doi: 10.1007/s13311-014-0309-7

Halene, T. B., \& Siegel, S. J. (2008). Antipsychotic-like properties of phosphodiesterase 4 inhibitors: evaluation of 4-(3-butoxy-4-methoxybenzyl)-2-imidazolidinone (RO-20-1724) with auditory event-related potentials and prepulse inhibition of startle. Journal of Pharmacology and Experimental Therapeutics, 326(1), 230-239. doi: 10.1124/jpet.108.138586

Heckman, P. R., Blokland, A., Ramaekers, J., \& Prickaerts, J. (2015). PDE and cognitive processing: beyond the memory domain. Neurobiology of Learning and Memory, 119, 108-122. doi: 10.1016/j.nlm.2014.10.011

Heckman, P. R., van Duinen, M. A., Bollen, E. P., Nishi, A., Wennogle, L., Blokland, A., \& Prickaerts, J. (2016). Phosphodiesterase inhibition and regulation of dopaminergic frontal and striatal functioning: clinical implications. International Journal of Neuropsychopharmacology. doi: 10.1093/ijnp/pyw030

Heckman, P. R., Wouters, C., \& Prickaerts, J. (2015). Phosphodiesterase inhibitors as a target for cognition enhancement in aging and Alzheimer's disease: a translational overview. Current Pharmaceutical Design, 21(3), 317-331.

Hershman, K. M., Freedman, R., \& Bickford, P. C. (1995). GABAB antagonists diminish the inhibitory gating of auditory response in the rat hippocampus. Neuroscience Letters, 190(2), 133-136. 
Jabaris, S. G., Sumathy, H., Kumar, R. S., Narayanan, S., Thanikachalam, S., \& Babu, C. S. (2015). Effects of rolipram and roflumilast, phosphodiesterase-4 inhibitors, on hypertension-induced defects in memory function in rats. European Journal of Pharmacology, 746, 138-147. doi: 10.1016/j.ejphar.2014.10.039

Javitt, D. C. (2009). Sensory processing in schizophrenia: neither simple nor intact. Schizophrenia Bulletin, 35(6), 1059-1064. doi: 10.1093/schbul/sbp110

Javitt, D. C., Spencer, K. M., Thaker, G. K., Winterer, G., \& Hajos, M. (2008). Neurophysiological biomarkers for drug development in schizophrenia. Nat Rev Drug Discov, 7(1), 68-83. doi: $10.1038 / \mathrm{nrd} 2463$

Jessen, F., Kucharski, C., Fries, T., Papassotiropoulos, A., Hoenig, K., Maier, W., \& Heun, R. (2001). Sensory gating deficit expressed by a disturbed suppression of the P50 event-related potential in patients with Alzheimer's disease. American Journal of Psychiatry, 158(8), 13191321.

Kleiman, R. J., Chapin, D. S., Christoffersen, C., Freeman, J., Fonseca, K. R., Geoghegan, K. F., . . . Schmidt, C. J. (2012). Phosphodiesterase 9A regulates central cGMP and modulates responses to cholinergic and monoaminergic perturbation in vivo. Journal of Pharmacology and Experimental Therapeutics, 341(2), 396-409. doi: 10.1124/jpet.111.191353

Klem, G. H., Luders, H. O., Jasper, H. H., \& Elger, C. (1999). The ten-twenty electrode system of the International Federation. The International Federation of Clinical Neurophysiology. Electroencephalography and Clinical Neurophysiology. Supplement, 52, 3-6.

Lahu, G., Nassr, N., \& Hunnemeyer, A. (2011). Pharmacokinetic evaluation of roflumilast. Expert Opinion on Drug Metabolism \& Toxicology, 7(12), 1577-1591. doi: 10.1517/17425255.2011.632409

Lakics, V., Karran, E. H., \& Boess, F. G. (2010). Quantitative comparison of phosphodiesterase mRNA distribution in human brain and peripheral tissues. Neuropharmacology, 59(6), 367-374. doi: 10.1016/j.neuropharm.2010.05.004

Light, G. A., Malaspina, D., Geyer, M. A., Luber, B. M., Coleman, E. A., Sackeim, H. A., \& Braff, D. L. (1999). Amphetamine disrupts P50 suppression in normal subjects. Biological Psychiatry, 46(7), 990-996.

Maurice, D. H., Ke, H., Ahmad, F., Wang, Y., Chung, J., \& Manganiello, V. C. (2014). Advances in targeting cyclic nucleotide phosphodiesterases. Nat Rev Drug Discov, 13(4), 290-314. doi: $10.1038 / \mathrm{nrd} 4228$

Maxwell, C. R., Kanes, S. J., Abel, T., \& Siegel, S. J. (2004). Phosphodiesterase inhibitors: a novel mechanism for receptor-independent antipsychotic medications. Neuroscience, 129(1), 101107. doi: 10.1016/j.neuroscience.2004.07.038

Menniti, F. S., Faraci, W. S., \& Schmidt, C. J. (2006). Phosphodiesterases in the CNS: targets for drug development. Nat Rev Drug Discov, 5(8), 660-670. doi: 10.1038/nrd2058

Micoulaud-Franchi, J. A., Vaillant, F., Lopez, R., Peri, P., Baillif, A., Brandejsky, L., . . . Vion-Dury, J. (2015). Sensory gating in adult with attention-deficit/hyperactivity disorder: Event-evoked potential and perceptual experience reports comparisons with schizophrenia. Biological Psychology, 107, 16-23. doi: 10.1016/j.biopsycho.2015.03.002

Nagamoto, H. T., Adler, L. E., Hea, R. A., Griffith, J. M., McRae, K. A., \& Freedman, R. (1996). Gating of auditory P50 in schizophrenics: unique effects of clozapine. Biological Psychiatry, 40(3), 181188. doi: 10.1016/0006-3223(95)00371-1

Nagy, D., Tingley, F. D., 3rd, Stoiljkovic, M., \& Hajos, M. (2015). Application of neurophysiological biomarkers for Huntington's disease: evaluating a phosphodiesterase 9A inhibitor. Experimental Neurology, 263, 122-131. doi: 10.1016/j.expneurol.2014.10.001

Olincy, A., Harris, J. G., Johnson, L. L., Pender, V., Kongs, S., Allensworth, D., . . Freedman, R. (2006). Proof-of-concept trial of an alpha7 nicotinic agonist in schizophrenia. Archives of General Psychiatry, 63(6), 630-638. doi: 10.1001/archpsyc.63.6.630

Oranje, B., Gispen-de Wied, C. C., Westenberg, H. G., Kemner, C., Verbaten, M. N., \& Kahn, R. S. (2004). Increasing dopaminergic activity: effects of L-dopa and bromocriptine on human sensory gating. J Psychopharmacol, 18(3), 388-394. doi: 10.1177/026988110401800310

Potter, D., Summerfelt, A., Gold, J., \& Buchanan, R. W. (2006). Review of clinical correlates of P50 sensory gating abnormalities in patients with schizophrenia. Schizophrenia Bulletin, 32(4), 692-700. doi: 10.1093/schbul/sbj050

Redrobe, J. P., Jorgensen, M., Christoffersen, C. T., Montezinho, L. P., Bastlund, J. F., Carnerup, M., . . Plath, N. (2014). In vitro and in vivo characterisation of Lu AF64280, a novel, brain penetrant 
phosphodiesterase (PDE) 2A inhibitor: potential relevance to cognitive deficits in schizophrenia. Psychopharmacology. doi: 10.1007/s00213-014-3492-7

Reneerkens, O. A., Rutten, K., Steinbusch, H. W., Blokland, A., \& Prickaerts, J. (2009). Selective phosphodiesterase inhibitors: a promising target for cognition enhancement. Psychopharmacology, 202(1-3), 419-443. doi: 10.1007/s00213-008-1273-x

Reneerkens, O. A., Sambeth, A., Blokland, A., \& Prickaerts, J. (2013). PDE2 and PDE10, but not PDE5, inhibition affect basic auditory information processing in rats. Behavioural Brain Research, 250, 251-256. doi: 10.1016/j.bbr.2013.05.014

Reneerkens, O. A., Sambeth, A., Van Duinen, M. A., Blokland, A., Steinbusch, H. W., \& Prickaerts, J. (2013). The PDE5 inhibitor vardenafil does not affect auditory sensory gating in rats and humans. Psychopharmacology, 225(2), 303-312. doi: 10.1007/s00213-012-2817-7

Richter, W., Menniti, F. S., Zhang, H. T., \& Conti, M. (2013). PDE4 as a target for cognition enhancement. Expert Opinion on Therapeutic Targets, 17(9), 1011-1027. doi: 10.1517/14728222.2013.818656

Sanchez-Morla, E. M., Santos, J. L., Aparicio, A., Garcia-Jimenez, M. A., Villanueva, C., MartinezVizcaino, V., \& Arango, C. (2009). Antipsychotic effects on auditory sensory gating in schizophrenia patients. European Neuropsychopharmacology, 19(12), 905-909. doi: 10.1016/j.euroneuro.2009.09.001

Schmidt, C. J., Chapin, D. S., Cianfrogna, J., Corman, M. L., Hajos, M., Harms, J. F., . . Menniti, F. S. (2008). Preclinical characterization of selective phosphodiesterase 10A inhibitors: a new therapeutic approach to the treatment of schizophrenia. Journal of Pharmacology and Experimental Therapeutics, 325(2), 681-690. doi: 10.1124/jpet.107.132910

Shim, S., Shuman, M., \& Duncan, E. (2016). An emerging role of cGMP in the treatment of schizophrenia: A review. Schizophrenia Research, 170(1), 226-231. doi: 10.1016/j.schres.2015.11.015

Siegel, S. J., Maxwell, C. R., Majumdar, S., Trief, D. F., Lerman, C., Gur, R. E., . . . Liang, Y. (2005). Monoamine reuptake inhibition and nicotine receptor antagonism reduce amplitude and gating of auditory evoked potentials. Neuroscience, 133(3), 729-738. doi: 10.1016/j.neuroscience.2005.03.027

Simosky, J. K., Stevens, K. E., Adler, L. E., \& Freedman, R. (2003). Clozapine improves deficient inhibitory auditory processing in $\mathrm{DBA} / 2$ mice, via a nicotinic cholinergic mechanism. Psychopharmacology, 165(4), 386-396. doi: 10.1007/s00213-002-1285-x

Siuciak, J. A. (2008). The role of phosphodiesterases in schizophrenia : therapeutic implications. CNS Drugs, 22(12), 983-993. doi: 10.2165/0023210-200822120-00002

Smucny, J., Stevens, K. E., Olincy, A., \& Tregellas, J. R. (2015). Translational utility of rodent hippocampal auditory gating in schizophrenia research: a review and evaluation. Transl Psychiatry, 5, e587. doi: 10.1038/tp.2015.77

Vanmierlo, T., Creemers, P., Akkerman, S., van Duinen, M., Sambeth, A., De Vry, J., . . Prickaerts, J. (2016). The PDE4 inhibitor roflumilast improves memory in rodents at non-emetic doses. Behavioural Brain Research, 303, 26-33. doi: 10.1016/j.bbr.2016.01.031

Wan, L., Crawford, H. J., \& Boutros, N. (2006). P50 sensory gating: impact of high vs. low schizotypal personality and smoking status. International Journal of Psychophysiology, 60(1), 1-9. doi: 10.1016/j.ijpsycho.2005.03.024

Wan, L., Crawford, H. J., \& Boutros, N. (2007). Early and late auditory sensory gating: moderating influences from schizotypal personality, tobacco smoking status, and acute smoking. Psychiatry Research, 151(1-2), 11-20. doi: 10.1016/j.psychres.2006.01.020

Wang, Z. Z., Zhang, Y., Zhang, H. T., \& Li, Y. F. (2015). Phosphodiesterase: an interface connecting cognitive deficits to neuropsychiatric and neurodegenerative diseases. Current Pharmaceutical Design, 21(3), 303-316.

Witten, L., Bastlund, J. F., Glenthoj, B. Y., Bundgaard, C., Steiniger-Brach, B., Mork, A., \& Oranje, B. (2016). Comparing Pharmacological Modulation of Sensory Gating in Healthy Humans and Rats: The Effects of Reboxetine and Haloperidol. Neuropsychopharmacology, 41(2), 638-645. doi: 10.1038/npp.2015.194

Yadon, C. A., Bugg, J. M., Kisley, M. A., \& Davalos, D. B. (2009). P50 sensory gating is related to performance on select tasks of cognitive inhibition. Cognitive, Affective \& Behavioral Neuroscience, 9(4), 448-458. doi: 10.3758/cabn.9.4.448 
Young, J. W., \& Geyer, M. A. (2013). Evaluating the role of the alpha-7 nicotinic acetylcholine receptor in the pathophysiology and treatment of schizophrenia. Biochemical Pharmacology, 86(8), 1122-1132. doi: 10.1016/j.bcp.2013.06.031

Zhang, X. Y., Liu, L., Liu, S., Hong, X., Chen, D. C., Xiu, M. H., . . Kosten, T. R. (2012). Short-term tropisetron treatment and cognitive and P50 auditory gating deficits in schizophrenia. American Journal of Psychiatry, 169(9), 974-981. doi: 10.1176/appi.ajp.2012.11081289 


\section{Chapter 5}

Effects of the phosphodiesterase type 4 inhibitor roflumilast on the tri-phasic response of the substantia nigra pars reticulata after infralimbic cortex stimulation

P.R.A. Heckman, J. V. Schweimer, T. Sharp, P. Magill, J. Prickaerts, A. Blokland Submitted to Journal of Neuroscience 


\section{ABSTRACT}

Fronto-striatal circuits constitute the neurobiological basis of many neuropsychiatric disorders. Part of the intracellular signaling within these circuits, including its dopaminergic modulation, is regulated by the cAMP/PKA signaling cascade. Based on the overall expression in human fronto-striatal circuitry, we tested the effects of a cAMP selective PDE4 inhibitor on the tri-phasic response in the dorsomedial substantia nigra pars reticulata $(\mathrm{SNr})$ upon stimulation of the infralimbic cortex in rats. Our results show for the first time that stimulation of the cognitive infralimbic cortex leads to a triphasic response in SNr neurons. In addition and in line with previous biochemical and behavioral studies, PDE4 inhibition by roflumilast affects both the direct pathway as well as the indirect pathway of which the latter appears more sensitive than the former.

Keywords: phosphodiesterase inhibitor, roflumilast, substantia nigra pars reticulata, fronto-striatal circuits 


\section{INTRODUCTION}

The fronto-striatal circuits are parallel organized circuits running from the frontal cortex, through the basal ganglia structures, to the thalamus from where they project back to the frontal cortex (Alexander et al., 1986; Alexander and Crutcher, 1990). The fronto-striatal circuits can be divided into three groups based on biological function, i.e. motor, associative/cognitive and limbic (Alexander et al., 1986). All circuits are characterized by their modulation by dopamine at the level of the striatum (Greengard et al., 1999; Greengard, 2001; Svenningsson et al., 2004) and their division into three pathways within the basal ganglia, i.e. the hyperdirect pathway, the direct pathway and the indirect pathway. Altogether, the fronto-striatal circuits comprise a complex mechanism of action and functionality, which is abundantly described elsewhere (e.g. Surmeier et al., 2007; Haber and Rauch, 2010; Gerfen and Surmeier, 2011; Surmeier et al., 2011; Calabresi et al., 2014).

In the striatum, dopaminergic neurotransmission is regulated by the cyclic adenosine monophosphate (CAMP)/protein kinase A (PKA) signaling cascade targeting effectors like cAMP response element-binding protein (CREB) and Dopamine- and CAMP-Regulated PhosphoProtein MR 32 kDa (DARPP-32) (Mayr and Montminy, 2001; Svenningsson et al., 2004). Consequently, dopaminergic signaling is regulated by phosphodiesterases (PDEs), as CAMP is degraded by PDEs. Because of its substrate CAMP and based on the overall expression in human fronto-striatal circuitry (Lakics et al., 2010), the PDE4 family is of particular interest (for a review see Heckman et al., 2016). However, little is known regarding the distinct expression of PDE4 within the three individual basal ganglia pathways.

Therefore, in the current study we used an in vivo electrophysiology approach to investigate the three basal ganglia pathways. For this we measured extracellular neural activity in the substantia nigra pars reticulata (SNr) during frontal cortex stimulation (Kolomiets et al., 2003). In particular, we were interested in the circuits involving cognitive function rather than fronto-striatal circuits involving motor or limbic functions (Deniau et al., 1996). In rats, these encompass the fronto-striatal circuits originating in the medial prefrontal cortex (mPFC; prelimbic and infralimbic cortices) and the orbitofrontal cortex. We focused on the circuit originating in the infralimbic cortex instead of the prelimbic cortex or orbitofrontal cortex, because sparse evidence confirms the existence of the three pathways (hyper, direct and indirect pathways) in this circuit. Also, the infralimbic cortex projections leave the basal ganglia mainly via the ventral pallidum (e.g. Deniau et al., 1994; Groenewegen et al., 1999) with less projections via the SNr (Vertes, 2004). We hypothesize that stimulation of the infralimbic cortex may lead to a tri-phasic response in the SNr (Maurice et al., 1999), topographically and functionally associated with the ventral parts of the basal ganglia. The temporal and topographic 
sensitivity of this electrophysiological response combined could directly address the distinctive effects of PDE4 inhibition in the three basal ganglia pathways, and thus determine PDE4 function and PDE4 inhibitor applicability to specifically influence fronto-striatal cognitive function.

\section{EXPERIMENTAL PROCEDURES}

\section{Animals}

A total of 24 male Wistar rats (age 3 months, 260-380 g, Charles River, Margate, Kent, UK) were used. Animals were housed collectively with ad libitum access to food and water. In the animal facility a normal 12-h light/dark cycle was maintained. In vivo electrophysiological experiments including drug administration were conducted during day time. All experiments were conducted at the University of Oxford at the University Department of Pharmacology in accordance with the Animals (Scientific Procedures) Act 1986 (UK) and were approved by a local Ethical Review Process at the University of Oxford.

\section{Electrophysiological recordings}

General anesthesia was induced with isoflurane (Isoflu, Abbott, Queenborough, Kent, UK) and maintained with urethane $(1.3-1.5 \mathrm{mg} / \mathrm{kg}$, ethyl carbamate, Sigma, Steinheim, Germany), supplemented with doses of ketamine $(30 \mathrm{mg} / \mathrm{kg}$, i.m.; Narketan, Vetoquinol, Buckingham, Buckinghamshire, UK) and xylazine (10 mg/kg, i.m.; Rompun, Bayer, Newbury, Berkshire, UK) whenever necessary. Subsequently, animals were placed in a stereotaxic frame (David Kopf Instruments, Tujunga, CA, USA). Surgery site was pretreated with bupivacaine for local anesthesia. Corneal dehydration was prevented by applications of Lacrilube eye gel (Allergan, Coolock, Dublin, Ireland). Body temperature was maintained at $37 \pm 0.5^{\circ} \mathrm{C}$ using a homeothermic heating blanket (Harvard Apparatus, Kent, UK).

An electrocorticogram (ECOG) was recorded over the left motor cortex $(2.6 \mathrm{~mm}$ posterior, $2.0 \mathrm{~mm}$ lateral to bregma) to monitor the depth of anaesthesia (see Schweimer et al. 2011 for details). Craniotomies were performed above the infralimbic cortex $(3.2 \mathrm{~mm}$ anterior, $0.6 \mathrm{~mm}$ lateral to bregma) for the stimulation electrode; and above the $\mathrm{SNr}(5.2 \mathrm{~mm}$ posterior, $2.0 \mathrm{~mm}$ lateral to bregma) for the recording electrode (Paxinos and Watson, 2009). Saline was applied to the exposed brain surface to prevent dehydration.

Extracellular neuronal activity was monitored with a 10-25 $\mathrm{M} \Omega$ glass microelectrode filled with $1.5 \%$ Neurobiotin (Vectorlabs, Burlingame, CA, USA) in $0.5 \mathrm{M} \mathrm{NaCl}$ (tip diameter 1-1.5 $\mu \mathrm{m}$ ). The 
microelectrode was lowered into the SNr with a single-axis in vivo micromanipulator (IVM) controlled via LINLAB software (Scientifica, Uckfield, UK). Electrode signals were alternating current (AC)coupled, amplified (1000x), and band-pass filtered (0.3-5 kHz) using a Neurolog system (Digitimer, Welwyn Garden City, Hertfordshire, UK) and acquired on-line through a Micro1401 interface and Spike2 software (Cambridge Electronic Design, Cambridge, Cambridgeshire, UK). Mains noise at $50 \mathrm{~Hz}$ was eliminated ('Humbug' filter, Brown et al., 2002) for single unit and ECoG recordings.

\section{Electrical stimulation of the medial prefrontal cortex (infralimbic cortex)}

Electrical stimulation of the infralimbic cortex (anterior: 3.2; lateral: 0.6 to bregma; ventral: $-4.5 \mathrm{~mm}$ from the cortical surface), ipsilateral to the recording SNr site, was performed with a bipolar coaxial stainless steel electrode (200 $\mu \mathrm{m}$ tip diameter, $500 \mu \mathrm{m}$ shaft diameter, $500 \mu \mathrm{m}$ exposed inner and outer contact; NE-100 Harvard Apparatus, UK) positioned stereotaxically according to Paxinos and Watson (2009). Electrical stimuli were generated from a constant current isolated stimulator (WPI A360 stimulus isolator, Sarasota, Florida, USA) controlled via a Master-8 (A.M.P.I., Israel). Stimulation consisted of monopolar pulses of $0.6 \mathrm{~ms}$ width and $500 \mu \mathrm{A}$ intensity delivered at a frequency of 1.4 $\mathrm{Hz}$.

\section{Drugs}

All drugs were freshly prepared before each experiment. Roflumilast (kindly provided by Takeda, Konstanz, Germany) was administered i.v. in accumulating doses $(0.0025,0.005$ and $0.01 \mathrm{mg} / \mathrm{kg}$ ). This was done to establish a dose-response curve and maximizing the data per animal, and thereby reduce animal numbers. Roflumilast was dissolved in 10\% Kolliphor HS 15 (Sigma-Aldrich, Schnelldorf, Germany) and $90 \%$ isotonic saline $(0.9 \%$, Scheller et al., 2014$)$ to make it suitable for i.v. administration.

\section{Extracellular single unit recordings of the $\mathrm{SNr}$ neurons, pharmacological treatment and experimental design}

Initially, the recording electrode was lowered to: anterior: $-5.2 \mathrm{~mm}$, lateral: $2.0 \mathrm{~mm}$ lateral to bregma; ventral: $-7.0 \mathrm{~mm}$ from the cortical surface according to Paxinos and Watson (2009). For each experiment the dorsal border of the SNr was located by identifying dopaminergic neurons of the SNc. Criteria for dopaminergic SNc neurons were broad action potentials ( $>1.1 \mathrm{~ms}$ ), and low to moderate frequency discharge (2-10 Hz) (Bunney et al., 1973; Ungless and Grace, 2012). Ventral of the SNc layer of dopaminergic neurons, SNr neurons can be found. Electrophysiological characteristics of the SNr neuron were thin spikes (width $<0.55 \mathrm{~ms}$ ), high-frequency discharge $(>10 \mathrm{~Hz}$ ) without a decrease in the spike amplitude (Bunney et al., 1973; Deniau et al., 1978; Kolomiets et al., 2003). Once an SNr 
neuron was detected a stable baseline firing rate was established for 2 minutes, followed by a 2 min stimulation period to check for the typical tri-phasic response of the SNr (excitation-inhibitionexcitation). Presence of a tri-phasic response was also used as electrophysiological characteristic of the SNr neuron. The recording pattern was repeated if the neuron exhibited a tri-phasic response to determine stable baseline spike train parameters as well as a stable tri-phasic response; followed by drug injections (i.v.) at 4 min intervals ( 2 min stimulation off and 2 min stimulation on). This allowed for testing of the effects of different doses of roflumilast on baseline spike train parameters as well as the SNr tri-phasic response (see Table 1).

Table 1. Schematic overview of the experimental stimulation and recordings

\begin{tabular}{|c|c|l|}
\hline Time (min) & $\begin{array}{c}\text { Stimulation } \\
\text { infralimbic cortex } \\
\text { (on/off) }\end{array}$ & Experimental step \\
\hline $\mathrm{T}=0$ & off & $\begin{array}{l}\text { Detection } \mathrm{SNr} \text { neuron according to electrophysiological } \\
\text { characteristics }\end{array}$ \\
\hline $\mathrm{T}=2$ & off & Establishment of stable baseline firing \\
\hline $\mathrm{T}=4$ & on & $\begin{array}{l}\text { Verification of typical tri-phasic response of the } \mathrm{SNr} \\
\text { (excitation-inhibition-excitation) after stimulation infralimbic } \\
\text { cortex }\end{array}$ \\
\hline $\mathrm{T}=6$ & off & Verification stable baseline spike train parameters \\
\hline $\mathrm{T}=8$ & on & Verification stable tri-phasic response \\
\hline $\mathrm{T}=10$ & off & Injection vehicle (i.v.) \\
\hline $\mathrm{T}=10$ & off & Measuring effects dosing on baseline spike train parameters \\
\hline $\mathrm{T}=12$ & on & Measuring effects dosing on tri-phasic response \\
\hline $\mathrm{T}=14$ & off & Injection 0.0025 mg/kg roflumilast (i.v.) \\
\hline $\mathrm{T}=14$ & off & Measuring effects dosing on baseline spike train parameters \\
\hline $\mathrm{T}=16$ & on & Measuring effects dosing on tri-phasic response \\
\hline $\mathrm{T}=18$ & off & Injection $0.005 \mathrm{mg} / \mathrm{kg}$ roflumilast (i.v.) \\
\hline $\mathrm{T}=18$ & off & Measuring effects dosing on baseline spike train parameters \\
\hline $\mathrm{T}=20$ & on & Measuring effects dosing on tri-phasic response \\
\hline $\mathrm{T}=22$ & off & Injection 0.01 mg/kg roflumilast (i.v.) \\
\hline $\mathrm{T}=22$ & off & Measuring effects dosing on baseline spike train parameters \\
\hline $\mathrm{T}=24$ & on & Measuring effects dosing on tri-phasic response \\
\hline $\mathrm{T}=26$ & off & Juxtacellular labelling or iontophoresis \\
\hline $\mathrm{T}=86$ & off & Leave to settle \\
\hline $\mathrm{T}=131$ & off & Transcardial perfusion \\
\hline $\mathrm{SN}=5 \mathrm{bsta}$ & & \\
\hline
\end{tabular}

$\mathrm{SNr}=$ substantia nigra pars reticulata; i.v. = intravenous injection 


\section{Histochemistry}

Following pharmacological treatment, animals were overdosed with pentobarbitone, brains were removed and kept in 4\% PFA overnight, before being transferred to a $30 \%$ sucrose solution for cryoprotection. Coronal sections $(30 \mu \mathrm{m})$ were cut using a cryostat (Bright Instruments Ltd, Luton, Bedfordshire, UK). Posterior sections containing the complete SNr were checked using a lightmicroscope (Leica Dialux 20) to verify recording electrode location. Additionally, PFC sections were stained using a standard Nissl-staining protocol to verify stimulation electrode location. Prior to the Nissl-staining, sections were mounted and hydrated in decreasing concentrations of ethanol. Following the Nissl-staining, sections were first dehydrated in increasing concentrations of ethanol and subsequently treated with isopropanol and xylene. Sections were examined under a lightmicroscope (Leica Dialux 20). Brightness and contrast of the images were adjusted using ImageJ software (version 1.50, ImageJ, National Institute of Health, Bethesda, MD, USA).

\section{Data and statistical analysis}

For the baseline periods, the interspike interval, coefficient of variation of the interspike interval, firing rate, and spike waveform width (time taken from a $5 \%$ increase from baseline to the first trough) were calculated for all neurons (e.g. Schweimer et al., 2011; Brouard et al., 2015).

We calculated the peristimulus-time histograms (PSTH) and response magnitudes as previously described in Beyeler et al. (2010). PSTH were generated for every 2 min stimulation period (5-ms bins). The baseline was defined as the mean of the spikes of the $100 \mathrm{~ms}$ epoch in each, individual PSTH preceding the cortical stimulation. In addition, the standard deviation (S.D.) of the baseline was determined. A significant excitation was considered if the mean of all bins within the excitatory epoch exceeded the mean baseline activity by 2 S.D. An inhibition was defined as a period during which the mean of bins of the inhibitory epoch is below $70 \%$ of the baseline mean (Georges and Aston-Jones, 2002).

Excitatory response magnitudes $\left(R_{\text {mags }}\right)$ were normalized for different levels of baseline activity, allowing for comparison of drug effects on evoked responses independent of effects on baseline activity or differences in firing rate (Georges and Aston-Jones, 2002). $R_{\text {mags }}$ for excitation were calculated with the following equation: Excitation $R_{\text {mag }}=$ (counts in excitatory epoch) - (mean counts per baseline bin $\mathrm{x}$ number of bins in excitatory epoch). In contrast, for the inhibition the $R_{\text {mag }}$ is expressed in absolute counts due to the low number of counts in the inhibition period. Expressing these low counts in the same way as positive $R_{\text {mags }}$ induces artificially high values (i.e., percentages) and high variability. The count numbers during the inhibition period were normally distributed and 
were comparable between the neurons. Finally, to determine the latency and the duration of each phase of the response, PSTH were generated from "2 minutes of" trials using 1-ms bins (Beyeler et al., 2010).

Statistical analysis was carried out using IBM SPSS Statistics 24 software (IBM, Portsmouth, UK). The raw data were checked for outliers and normality of distribution. Missing values were replaced using the multiple imputation function in SPSS using 5 imputations (Olivier et al., 2009). One-way repeated measures analysis of variance (ANOVA) followed by Sidak's post-hoc test was used. Data are depicted as means $\pm \mathrm{SEM}$.

\section{RESULTS}

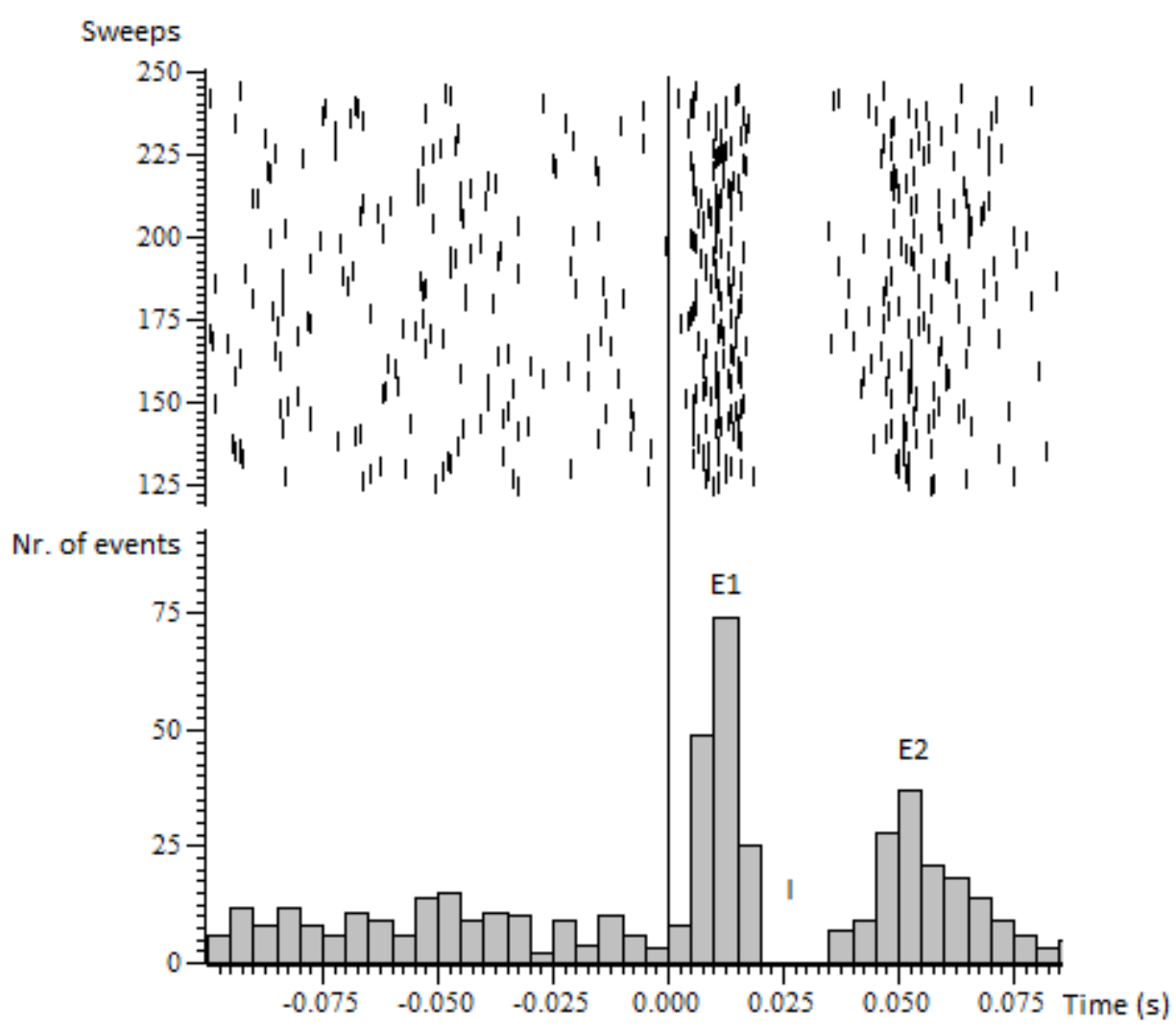

Figure 1. Raster plot and peristimulus-time histogram demonstrating a typical tri-phasic (excitation-inhibitionexcitation) response of a $\mathrm{SNr}$ neuron to infralimbic cortex stimulation. Vertical line at $\mathrm{T}=0$ represents the time of stimulation; E1= early excitation phase of the tri-phasic response; I= inhibition phase of the tri-phasic response; E2= late excitation phase of the tri-phasic response. Baseline firing properties of SNr neurons displaying a tri-phasic response $(\mathrm{N}=6)$ : Average spike waveform width: $0.0013 \pm 0.00021(\mathrm{~s})$; Firing rate $(\mathrm{Hz})$ : 
$25.89 \pm 3.81$; Coefficient of variation of the interspike interval: $0.25 \pm 0.017$; Latency first excitation(s): $0.0048 \pm$ 0.0014 .

\section{Effects of roflumilast on basal SNr neuron activity}

In order to determine the effect of roflumilast in the cognitive fronto-striatal circuit originating in the infralimbic cortex we recorded in 24 rats 65 neurons that exhibited an electrophysiological profile corresponding to the SNr criteria (see 'Experimental procedures' section). Figure 1 shows a typical triphasic response of the SNr after infralimbic cortex stimulation including baseline firing properties. Recordings of these neurons showed that about $50 \%$ of these neurons $(n=33)$ responded to electrical stimulation of the infralimbic cortex (infralimbic cortex electrode location verified; see figure 2). Among these 33 neurons only $18 \%$ showed a tri-phasic response $(n=6)$. This percentage corroborates earlier findings observed in earlier studies where the auditory-, motor-, and pre-limbic cortices were stimulated (Maurice et al., 1999; Kolomiets et al., 2003). Only SNr neurons exhibiting a tri-phasic response were included in the analysis because they represent activation of the full circuit of interest (see figure 2).

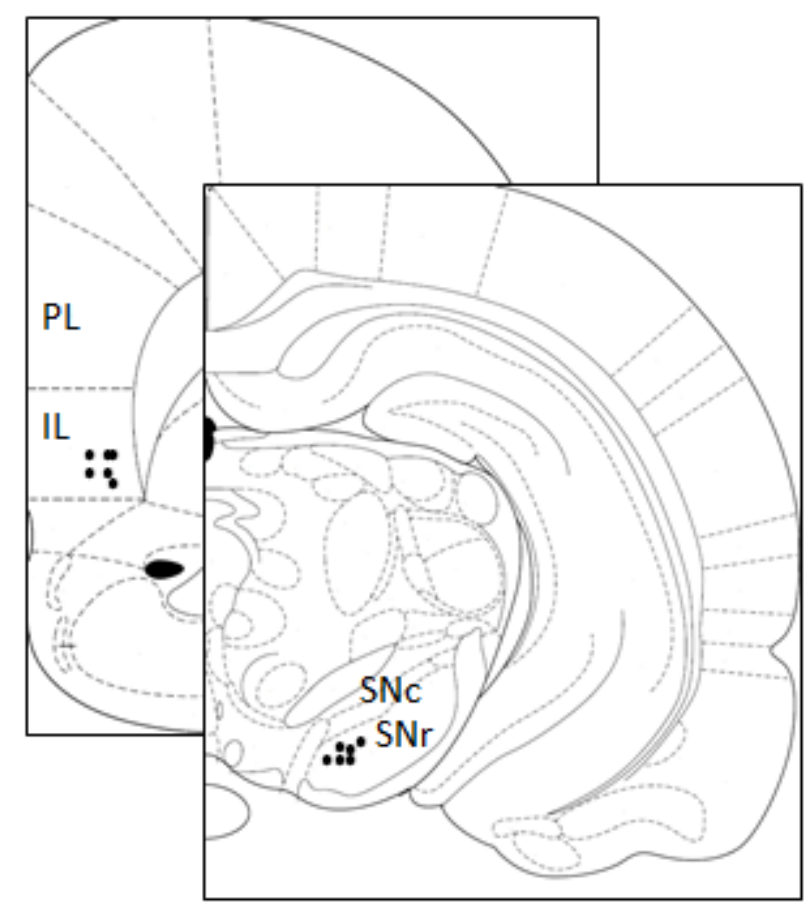

Figure 2. Graphical depiction of stimulation and recording electrode locations for the 6 neurons exhibiting a triphasic response (stimulation electrode: coronal section anterior: $3.2 \mathrm{~mm}$ to bregma; recording electrode: coronal section anterior: $-5.3 \mathrm{~mm}$ to bregma). $\mathrm{PL}=$ prelimbic cortex; IL=infralimbic cortex; $\mathrm{SNc}=$ substantia nigra pars compacta (dorsal tier); SNr=substantia nigra pars reticulata 
Before analyzing the effects of roflumilast on any of the baseline spike train parameters or the triphasic response we first verified that the (repeated) stimulation of the infralimbic cortex or the injection had no effect on any of the parameters investigated. Neither stimulation itself nor the injection had an effect on the baseline firing (data not shown). Subsequently, roflumilast had no effect on baseline firing properties of the recorded neurons (firing rate, or regularity (COV IS), data not shown).

The physiological response to stimulation of the SNr neurons was compatible with previous data (Ryan and Sanders, 1994; Kolomiets et al., 2003; Beyeler et al., 2010) regarding the delay of appearance and the duration of each phase of the tri-phasic response. Location of responding (cognitive) neurons within the SNr is in line with the division of motor, cognitive (associative) and limbic areas within the SNr (e.g. Kolomiets et al., 2003).

\section{Effects of roflumilast on mPFC stimulation-evoked responses of SNr neurons}

The tri-phasic response that was measured represents activation of the hyper direct, direct and indirect basal ganglia pathways. Each individual pathway is measured as early excitation, inhibition and late excitation, respectively. At stimulation (no treatment), latencies and durations were as follow (in ms $\pm S E M ; n=6$ ) for the early excitation phase: $4.8 \pm 1.4$ and $10.8 \pm 1.5$, respectively. For the inhibition phase this was $20.17 \pm 1.8$ and $12.67 \pm 0.99$, respectively, and for the late excitation phase these values were $36.5 \pm 2.5$ and $13.67 \pm 2.0$, respectively. These values were not affected during the different stages of the experiment and did not change after roflumilast treatment. Thus, roflumilast had no effect on the latency or duration of the tri-phasic response.

No effects of roflumilast were observed for the $R_{\text {mag }}$ of the early excitation phase (figure $3 \mathrm{~A}$ ). Roflumilast increased the firing rate during the inhibition phase $(F(3,15)=6.294, p=0.006)$. Post-hoc test revealed a $117 \%$ increase in the firing rate after $0.01 \mathrm{mg} / \mathrm{kg}$ (figure $3 \mathrm{~B} ; p=0.049$ ). The calculated effect size for this difference was 1.06 (Cohen's D), which can be considered as a large effect size. For the late excitation phase the $R_{\text {mag }}$ the repeated measures ANOVA showed a marginal treatment effect $(F(3,15)=3.05, \mathrm{p}=0.06)$. However, post-hoc analysis revealed a $50 \%$ decrease in $R_{\text {mag }}$ after $0.005 \mathrm{mg} / \mathrm{kg}$ roflumilast treatment when compared with vehicle (figure 3C; $p=0.035$ ). The calculated effect size for this difference was 1.58 (Cohen's D), which can be considered as a large effect size. 
A

Early excitation phase (E1)

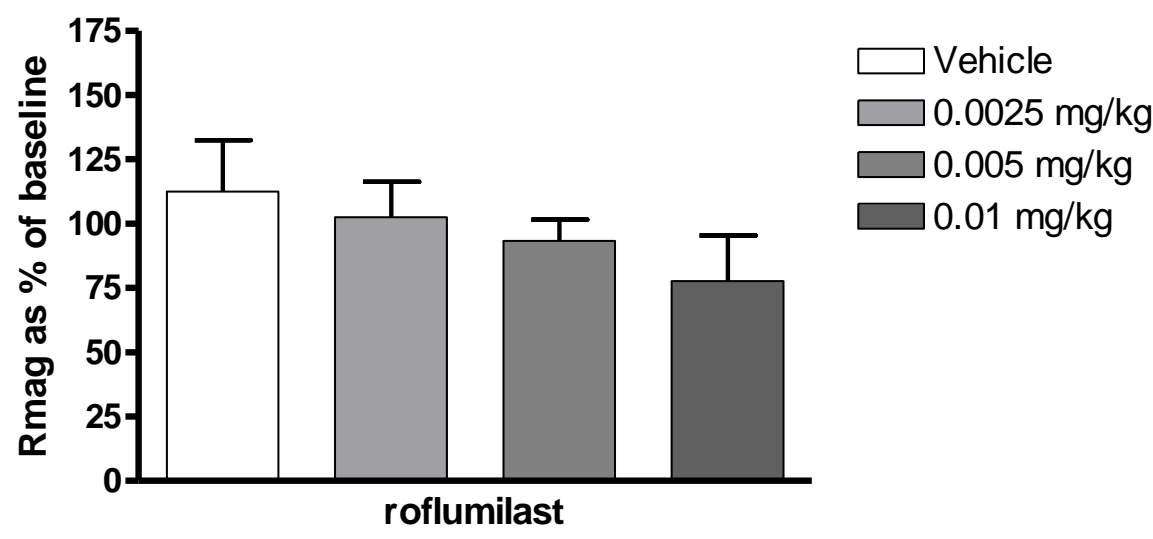

B Inhibition phase (I)

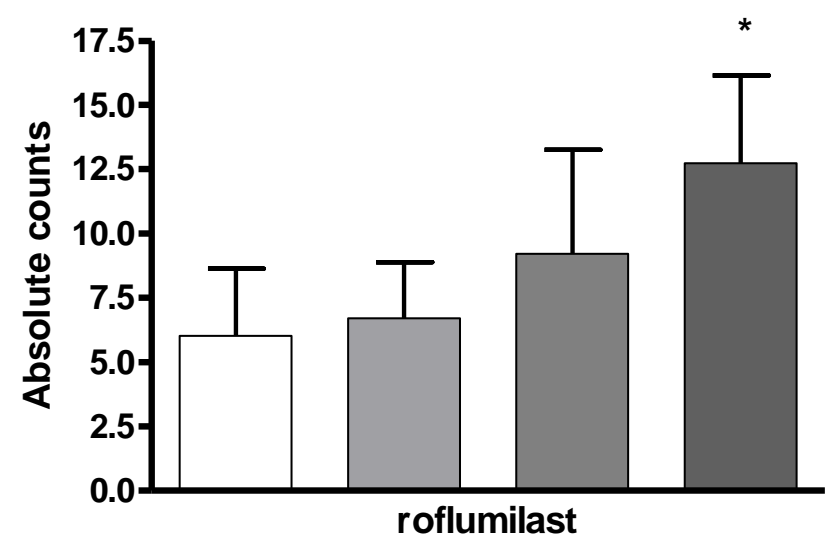

$\square$ Vehicle

$\square 0.0025 \mathrm{mg} / \mathrm{kg}$

$\square 0.005 \mathrm{mg} / \mathrm{kg}$

$\square 0.01 \mathrm{mg} / \mathrm{kg}$

C

Late excitation phase (E2)

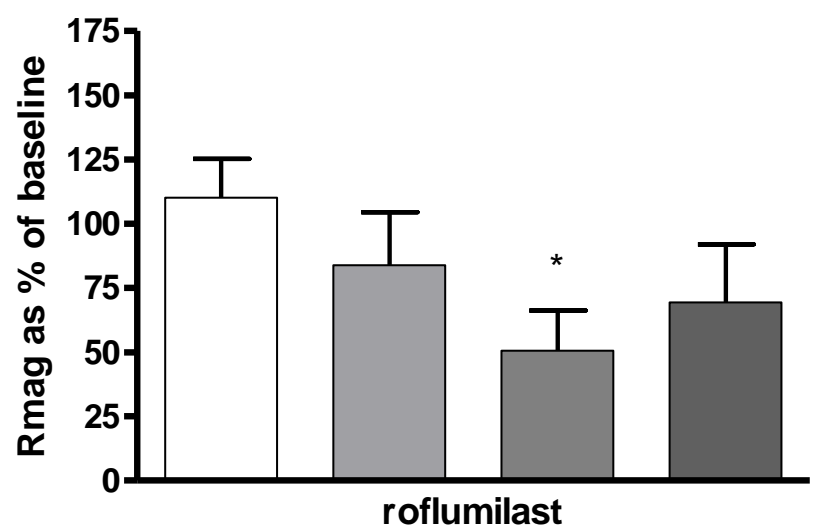

$\square$ Vehicle

$0.0025 \mathrm{mg} / \mathrm{kg}$

$\square 0.005 \mathrm{mg} / \mathrm{kg}$

$\square 0.01 \mathrm{mg} / \mathrm{kg}$

Figure 3. Effects of the PDE4 inhibitor roflumilast on the magnitude of the electrophysiological response of the $\mathrm{SNr}$ neurons to electrical stimulation of the infralimbic cortex. Each bar represents the magnitude of the response ( $R_{\text {mag }}$ as \% of baseline for the early (E1) and late (E2) excitation phases, and absolute counts for the inhibition (I) phase). (A) Roflumilast did not affect the $R_{\text {mag }}$ of the early excitation phase. (B) Roflumilast 
decreased the magnitude of the inhibition as depicted by an increase in the absolute number of counts at the $0.01 \mathrm{mg} / \mathrm{kg}$ dose. (C) In the late excitation phase a decrease in $R_{\text {mag }}$ was found at the $0.005 \mathrm{mg} / \mathrm{kg}$ dose.

\section{DISCUSSION}

The current study was conducted to address the distinctive effects of PDE4 inhibition on the three basal ganglia pathways: the hyperdirect, direct and indirect pathway. This was done by examining the effects on the tri-phasic (excitation-inhibition-excitation) response of the SNr after infralimbic cortex stimulation. Our results provide support for the hypothesis that PDE4 inhibition affects the direct and indirect pathways of the basal ganglia, but not the hyperdirect pathway. This conclusion is in line with previous findings supporting a role for PDE4 in the direct and indirect pathways originating in striatal medium spiny neurons (Nishi et al., 2008; Nishi and Snyder, 2010; Nishi et al., 2011; Heckman et al., 2016). The current data support the notion that PDE4 has a preferential role in the indirect pathway since PDE4 inhibition reduced the $R_{\text {mag }}$ of the indirect pathway at a lower dose when compared to the neuronal activity in the direct pathway.

Previous studies showed that PDE4 predominantly regulates CAMP/PKA signaling at striatal dopaminergic terminals and associated dopamine synthesis and release (Schoffelmeer et al., 1985; Yamashita et al., 1997a; Yamashita et al., 1997b; Nishi et al., 2008). Secondary to this, PDE4 regulates cAMP/PKA signaling in medium spiny neurons. This is the case for both the striatopallidal as well as the striatonigral pathway as was observed by increased levels of phospho-DARPP-32 in neostriatal slices in both pathways after PDE4 inhibitor treatment (Nishi et al., 2008). These findings were supported by immunohistochemistry data. Of note, higher expression levels were observed in (indirect) striatopallidal neurons but only the PDE4B subtype was examined. Interestingly, PDE4 inhibition only potentiated adenosine $A_{2 a}$ receptor -induced phosphorylation of DARPP-32 by the adenosine $A_{2 a}$ receptor agonist CGS21680, whereas no additional effects of PDE4 inhibition were observed after stimulation of the dopamine D1 receptor with SKF81297 (Nishi and Snyder, 2010). The latter can be interpreted as a preferential effect of PDE4 inhibition in striatopallidal neurons as $A_{2 a}$ receptors are located on indirect pathway MSNs and D1 receptors on direct pathway MSN (Gerfen and Surmeier, 2011).

However, slices do not need to represent the in vivo situation as for instance, as mentioned earlier, the observed increase in DARPP-32 phosphorylation after rolipram treatment in neostriatal slices could not be observed in vivo by the same group (Nishi et al., 2008). Clearly, when studying the fronto-striatal circuitry the striatal slices can only model part of this circuitry and may therefore not 
be the most suitable model for studying a fully intact functional circuit. Therefore, the current study is unique in providing support for a more sensitive indirect pathway for PDE4 inhibition.

The more potent effect of roflumilast in the indirect pathway can be hypothesized to occur from several possibilities. One option would entail lower levels of PDE4 expression in medium spiny neurons of the indirect striatopallidal pathway compared to the direct striatonigral pathway. This way, the same dose of the compound can induce larger effects since absolute lower number of PDE4 proteins in the indirect pathway compared to the direct pathway. Another possibility to explain the observed effect would be that the direct pathway contains higher levels of PDE4 when compared to the indirect pathway. That way a higher dose of roflumilast is needed to inhibit higher levels of PDE4 compared to the indirect pathway before CAMP and related signaling is affected.

Also, the tri-phasic response measured in the SNr originates in the frontal cortex and is modulated at many different levels throughout the system before reaching the output module of the basal ganglia. For instance, even though the same intracellular effectors are involved in frontal and striatal dopaminergic signaling, biosensor imaging in mouse brain slice preparations showed profound differences in the D1 response between pyramidal cortical neurons and striatal medium spiny neurons (Castro et al., 2013). Furthermore, it is unknown in which nigral and pallidal areas or where within the subthalamic nucleus PDE4 is expressed. The abundant number of feedback and feedforward connections within the circuits as well as their mediation and modulation by several neurotransmitter systems add to the complexity of predicting the net effect reaching the output modules of the basal ganglia (Gerfen and Surmeier, 2011; Surmeier et al., 2011; Calabresi et al., 2014). The latter aspects could be responsible for the unexpected finding in both pathways, i.e. increased firing in the inhibition phase and decreased firing in the late excitation phase after roflumilast treatment. Future studies will have to investigate these possible mechanisms at the cellular and molecular level further (e.g. Nishi et al., 2017; Nishi and Shuto, 2017).

Even though our results are in line with previous findings in neostriatal slices and on behavioral outcomes, some difference must be highlighted. For instance, in the current study we examined the effects of a PDE4 inhibitor in anaesthetized animals while behavioral studies discussed above examine fully awake and active animals. This means that, although the brain circuitry is intact and functional, it cannot be ruled out that different effects of roflumilast could be observed when conducting electrophysiological recordings in fully awake and freely moving animals. Since PDE4 is most prominently expressed at dopaminergic terminals affecting synthesis and release of dopamine in the striatum, a dopaminergic challenge of the brain circuitry may greatly affect fronto-striatal 
signaling. The latter is more likely to occur in freely moving animals during behavioral tasks compared to anaesthetized animals (Sabeti et al., 2003). However, the former would also introduce more noise and thus variability in the data, when the research question reflects merely the examination of the effects of the drug. Another difference to address is that in the study examining striatal slices, the classic PDE4 inhibitor rolipram was used opposed to roflumilast in the current study, even though both inhibitors are selective for PDE4 over other PDE subfamilies and both have equal selectivity for the four PDE4 subtypes (Krause and Kuhne, 1988; Hatzelmann et al., 2010).

In line with previous studies (e.g. Deniau et al., 1994; Groenewegen et al., 1999; Vertes, 2004) cells exhibiting a tri-phasic response were located in the dorsomedial SNr. Results of the current study further add to the evidence that cognitive projections, or at least those originating in the infralimbic cortex, can induce a tri-phasic response in the SNr. As a result, it also implies the existence of a division within the basal ganglia into a hyper, direct and indirect pathway, in the cognitive frontostriatal circuit originating in the infralimbic cortex. Thus, this also confirms the hypothesis of the existence of the three pathways in the cognitive fronto-striatal circuits as they do in the motor or limbic circuits (e.g. Maurice et al., 1999; Beyeler et al., 2010).

In conclusion, our results show that stimulation of the infralimbic cortex leads to a tri-phasic response in a subset of neurons in the SNr. This is topographically and functionally associated with the cognitive parts of the basal ganglia, that can be used to investigate distinctive effects of drugs within the basal ganglia circuitry. The temporal and topographic sensitivity of this tri-phasic electrophysiological response combined with the neuroanatomical markers directly addressed the distinctive effects of PDE4 inhibition by roflumilast in the three basal ganglia pathways of the cognitive fronto-striatal circuitry. PDE4 inhibition by roflumilast appears to affect both the direct pathway as well as the indirect pathway with a relative preference for the latter. These findings are in line with previous in vitro and in vivo studies. Further studies may reveal whether PDE4 inhibition could be considered as a possible treatment for cognitive deficits related to fronto-striatal disorders in which either the direct or indirect pathway is affected (e.g., schizophrenia and attention deficit hyperactivity disorder, Huntington's disease and Parkinson's disease). 


\section{References}

Alexander GE, Crutcher MD (1990) Functional architecture of basal ganglia circuits: neural substrates of parallel processing. Trends Neurosci 13:266-271.

Alexander GE, DeLong MR, Strick PL (1986) Parallel organization of functionally segregated circuits linking basal ganglia and cortex. Annu Rev Neurosci 9:357-381.

Beyeler A, Kadiri N, Navailles S, Boujema MB, Gonon F, Moine CL, Gross C, De Deurwaerdere P (2010) Stimulation of serotonin $2 \mathrm{C}$ receptors elicits abnormal oral movements by acting on pathways other than the sensorimotor one in the rat basal ganglia. Neuroscience 169:158-170.

Brouard JT, Schweimer JV, Houlton R, Burnham KE, Queree P, Sharp T (2015) Pharmacological Evidence for 5-HT6 Receptor Modulation of 5-HT Neuron Firing in Vivo. ACS Chem Neurosci 6:1241-1247.

Brown P, Kupsch A, Magill PJ, Sharott A, Harnack D, Meissner W (2002) Oscillatory local field potentials recorded from the subthalamic nucleus of the alert rat. Exp Neurol 177:581-585.

Bunney BS, Walters JR, Roth RH, Aghajanian GK (1973) Dopaminergic neurons: effect of antipsychotic drugs and amphetamine on single cell activity. J Pharmacol Exp Ther 185:560-571.

Calabresi P, Picconi B, Tozzi A, Ghiglieri V, Di Filippo M (2014) Direct and indirect pathways of basal ganglia: a critical reappraisal. Nat Neurosci 17:1022-1030.

Castro LR, Brito M, Guiot E, Polito M, Korn CW, Herve D, Girault JA, Paupardin-Tritsch D, Vincent P (2013) Striatal neurones have a specific ability to respond to phasic dopamine release. J Physiol 591:3197-3214.

Deniau JM, Menetrey A, Thierry AM (1994) Indirect nucleus accumbens input to the prefrontal cortex via the substantia nigra pars reticulata: a combined anatomical and electrophysiological study in the rat. Neuroscience 61:533-545.

Deniau JM, Menetrey A, Charpier S (1996) The lamellar organization of the rat substantia nigra pars reticulata: segregated patterns of striatal afferents and relationship to the topography of corticostriatal projections. Neuroscience 73:761-781.

Deniau JM, Hammond C, Riszk A, Feger J (1978) Electrophysiological properties of identified output neurons of the rat substantia nigra (pars compacta and pars reticulata): evidences for the existence of branched neurons. Exp Brain Res 32:409-422.

Georges F, Aston-Jones G (2002) Activation of ventral tegmental area cells by the bed nucleus of the stria terminalis: a novel excitatory amino acid input to midbrain dopamine neurons. J Neurosci 22:5173-5187.

Gerfen CR, Surmeier DJ (2011) Modulation of striatal projection systems by dopamine. Annu Rev Neurosci 34:441-466.

Greengard P (2001) The neurobiology of dopamine signaling. Biosci Rep 21:247-269.

Greengard P, Allen PB, Nairn AC (1999) Beyond the dopamine receptor: the DARPP-32/protein phosphatase-1 cascade. Neuron 23:435-447.

Groenewegen HJ, Galis-de Graaf Y, Smeets WJ (1999) Integration and segregation of limbic corticostriatal loops at the thalamic level: an experimental tracing study in rats. J Chem Neuroanat 16:167-185.

Haber SN, Rauch SL (2010) Neurocircuitry: a window into the networks underlying neuropsychiatric disease. Neuropsychopharmacology 35:1-3.

Hatzelmann A, Morcillo EJ, Lungarella G, Adnot S, Sanjar S, Beume R, Schudt C, Tenor H (2010) The preclinical pharmacology of roflumilast--a selective, oral phosphodiesterase 4 inhibitor in development for chronic obstructive pulmonary disease. Pulm Pharmacol Ther 23:235-256.

Heckman PR, van Duinen MA, Bollen EP, Nishi A, Wennogle L, Blokland A, Prickaerts J (2016) Phosphodiesterase inhibition and regulation of dopaminergic frontal and striatal functioning: clinical implications. Int J Neuropsychopharmacol.

Kolomiets BP, Deniau JM, Glowinski J, Thierry AM (2003) Basal ganglia and processing of cortical information: functional interactions between trans-striatal and trans-subthalamic circuits in the substantia nigra pars reticulata. Neuroscience 117:931-938. 
Krause W, Kuhne G (1988) Pharmacokinetics of rolipram in the rhesus and cynomolgus monkeys, the rat and the rabbit. Studies on species differences. Xenobiotica 18:561-571.

Lakics V, Karran EH, Boess FG (2010) Quantitative comparison of phosphodiesterase mRNA distribution in human brain and peripheral tissues. Neuropharmacology 59:367-374.

Maurice N, Deniau JM, Glowinski J, Thierry AM (1999) Relationships between the prefrontal cortex and the basal ganglia in the rat: physiology of the cortico-nigral circuits. J Neurosci 19:46744681.

Mayr B, Montminy M (2001) Transcriptional regulation by the phosphorylation-dependent factor CREB. Nat Rev Mol Cell Biol 2:599-609.

Nishi A, Snyder GL (2010) Advanced research on dopamine signaling to develop drugs for the treatment of mental disorders: biochemical and behavioral profiles of phosphodiesterase inhibition in dopaminergic neurotransmission. J Pharmacol Sci 114:6-16.

Nishi A, Shuto T (2017) Potential for targeting dopamine/DARPP-32 signaling in neuropsychiatric and neurodegenerative disorders. Expert Opin Ther Targets:1-14.

Nishi A, Kuroiwa M, Shuto $T$ (2011) Mechanisms for the modulation of dopamine $d(1)$ receptor signaling in striatal neurons. Front Neuroanat 5:43.

Nishi A, Matamales M, Musante V, Valjent E, Kuroiwa M, Kitahara Y, Rebholz H, Greengard P, Girault JA, Nairn AC (2017) Glutamate Counteracts Dopamine/PKA Signaling via Dephosphorylation of DARPP-32 Ser-97 and Alteration of Its Cytonuclear Distribution. J Biol Chem 292:14621476.

Nishi A, Kuroiwa M, Miller DB, O'Callaghan JP, Bateup HS, Shuto T, Sotogaku N, Fukuda T, Heintz N, Greengard P, Snyder GL (2008) Distinct roles of PDE4 and PDE10A in the regulation of cAMP/PKA signaling in the striatum. J Neurosci 28:10460-10471.

Olivier JD, Jans LA, Blokland A, Broers NJ, Homberg JR, Ellenbroek BA, Cools AR (2009) Serotonin transporter deficiency in rats contributes to impaired object memory. Genes, brain, and behavior 8:829-834.

Ryan L, Sanders DJ (1994) Subthalamic nucleus and globus pallidus lesions alter activity in nigrothalamic neurons in rats. Brain Res Bull 34:19-26.

Sabeti J, Gerhardt GA, Zahniser NR (2003) Chloral hydrate and ethanol, but not urethane, alter the clearance of exogenous dopamine recorded by chronoamperometry in striatum of unrestrained rats. Neurosci Lett 343:9-12.

Scheller KJ, Williams SJ, Lawrence AJ, Jarrott B, Djouma E (2014) An improved method to prepare an injectable microemulsion of the galanin-receptor 3 selective antagonist, SNAP 37889, using Kolliphor((R)) HS 15. MethodsX 1:212-216.

Schoffelmeer AN, Wardeh G, Mulder AH (1985) Cyclic AMP facilitates the electrically evoked release of radiolabelled noradrenaline, dopamine and 5-hydroxytryptamine from rat brain slices. Naunyn Schmiedebergs Arch Pharmacol 330:74-76.

Schweimer JV, Mallet N, Sharp T, Ungless MA (2011) Spike-timing relationship of neurochemicallyidentified dorsal raphe neurons during cortical slow oscillations. Neuroscience 196:115-123.

Surmeier DJ, Carrillo-Reid L, Bargas J (2011) Dopaminergic modulation of striatal neurons, circuits, and assemblies. Neuroscience 198:3-18.

Surmeier DJ, Ding J, Day M, Wang Z, Shen W (2007) D1 and D2 dopamine-receptor modulation of striatal glutamatergic signaling in striatal medium spiny neurons. Trends Neurosci 30:228235.

Svenningsson P, Nishi A, Fisone G, Girault JA, Nairn AC, Greengard P (2004) DARPP-32: an integrator of neurotransmission. Annu Rev Pharmacol Toxicol 44:269-296.

Ungless MA, Grace AA (2012) Are you or aren't you? Challenges associated with physiologically identifying dopamine neurons. Trends Neurosci 35:422-430.

Vertes RP (2004) Differential projections of the infralimbic and prelimbic cortex in the rat. Synapse 51:32-58.

Yamashita N, Hayashi A, Baba J, Sawa A (1997a) Rolipram, a phosphodiesterase-4-selective inhibitor, promotes the survival of cultured rat dopaminergic neurons. Jpn J Pharmacol 75:155-159. 
Yamashita N, Miyashiro M, Baba J, Sawa A (1997b) Rolipram, a selective inhibitor of phosphodiesterase type 4, pronouncedly enhanced the forskolin-induced promotion of dopamine biosynthesis in primary cultured rat mesencephalic neurons. Jpn J Pharmacol 75:91-95. 


\section{Chapter 6}

The mediating role of phosphodiesterase type 4 in the dopaminergic modulation of motor impulsivity

P.R.A. Heckman, A. Blokland and J. Prickaerts In preparation 


\begin{abstract}
The current study investigates the mediating role of PDE4 in the dopaminergic modulation of premature responding (motor impulsivity). Response inhibition, which includes action restraint, finds its neurobiological origin in fronto-striatal circuitry and can be modulated by dopamine. Intracellularly, the effect of dopamine is largely mediated through the cAMP/PKA signaling cascade. It has been suggested that areas in the prefrontal cortex are very sensitive to their neurochemical environment, including catecholamine levels. Both high and low catecholamine release in the prefrontal cortex impairs prefrontal cortex function. As a result, we investigated the effects of PDE4 inhibition on premature responding in a hypo, normal and hyper dopaminergic state of the brain. As a hypo dopaminergic model we will induce a 6-OHDA lesion in the prefrontal cortex, more specifically the infralimbic cortex. For the hyperdopaminergic state we also turn to a well-established model of impaired action restraint, namely the systemic administration of $d$-amphetamine. Results indicated a role for PDE4 inhibitors in shifting performance on premature responding to the right on the Ushaped dose response curve. As a result, it would be interesting to test the effects of PDE4 inhibition in disorders affected by disrupted impulse control related to fronto-striatal hypodopaminergia including ADHD.
\end{abstract}




\section{Introduction}

Controlling impulsivity is of vital importance for decision making. A lack of control of your impulsive responding can have severe consequences and lead to various psychiatric disorders. For example, addiction, attention deficit hyperactivity disorder (ADHD), obsessive-compulsive disorder (OCD), eating disorders and pathological gambling (Aron 2007; Aron and Poldrack 2005; Bellgrove et al. 2006; Durston et al. 2008; Fillmore and Rush 2002; Fillmore et al. 2002, 2006; Gauggel et al. 2004; Monterosso et al. 2005; Nigg et al. 2004; Oosterlaan et al. 1998; Penadés et al. 2007; Rubia et al. 1998; Rubia et al. 2007; Rubia et al. 2005; Schachar et al. 2007; Schachar et al. 1995; van den Wildenberg et al. 2006; Dalley and Robbins 2017). Impulsivity is a multifaceted concept and in daily life it comes in many different forms (Evenden 1999; Cardinal et al. 2004; Winstanley et al. 2006). To make this multifaceted concept easier to study impulsivity, is generally divided into impulsive actions, i.e. an inability to inhibit a response, and impulsive choices, i.e. a distorted judgment with respect to choosing between two differential reward outcomes. A third main type of impulsivity is reflection impulsivity, making decisions before adequately sampling and evaluating available information. However, splitting the behavioral construct into six subcategories is perhaps more appropriate (see Table 1). Within impulsive actions there is a clear distinction between action restraint (inhibiting a prepotent, inappropriate response) and action cancellation, i.e. response inhibition or volitional control over responding once the response has been initiated. Impulsive choice may be subdivided into delay-, uncertainty-, and effort-based decision making. Impulsivity is a critical component of psychiatric symptoms within the class of 'inhibition' and is separated from compulsivity, perseveration, disinhibition, obsession, aggression, attention and mania (Aron 2007).

\section{Table 1. Types of impulsivity}

\begin{tabular}{|l|l|l|}
\hline \multicolumn{1}{|c|}{ Type of impulsivity } & \multicolumn{1}{|c|}{ Cognitive domain } & \multicolumn{1}{c|}{ Description } \\
\hline Impulsive action & $\begin{array}{l}\text { Action restraint; motor } \\
\text { impulsivity }\end{array}$ & $\begin{array}{l}\text { Ability to inhibit } \\
\text { prepotent, inappropriate } \\
\text { responses }\end{array}$ \\
\hline & $\begin{array}{l}\text { Action cancellation; } \\
\text { response inhibition }\end{array}$ & $\begin{array}{l}\text { Ability to inhibit actions } \\
\text { once initiated }\end{array}$ \\
\hline Impulsive choice & $\begin{array}{l}\text { Delay-based decision } \\
\text { making }\end{array}$ & $\begin{array}{l}\text { Decision making based } \\
\text { on delay-aversion }\end{array}$ \\
\hline & $\begin{array}{l}\text { Uncertainty-based } \\
\text { decision making }\end{array}$ & $\begin{array}{l}\text { Decision making based } \\
\text { on risk-seeking }\end{array}$ \\
\hline Reflection impulsivity & $\begin{array}{l}\text { Effort-based decision } \\
\text { making }\end{array}$ & $\begin{array}{l}\text { Decision making based } \\
\text { on effort-aversion }\end{array}$ \\
\hline Information sampling & $\begin{array}{l}\text { Ability to evaluate } \\
\text { available information } \\
\text { prior to making a } \\
\text { decision }\end{array}$ \\
\hline
\end{tabular}


Current knowledge on the human neuroanatomical substrate of impulse control points to the frontostriatal circuits (Alexander et al. 1986; Dalley et al. 2011; Chudasama and Robbins 2006). The frontostriatal circuits comprise a complex mechanism of action and functionality, which is abundantly described elsewhere (e.g. Surmeier et al. 2007; Haber and Rauch 2010; Gerfen and Surmeier 2011; Surmeier et al. 2011; Calabresi et al. 2014; Calabresi et al. 2000). Although the general anatomical organization related to impulse control is known, the different subtypes of impulsivity arise from the dysfunction of different fundamental anatomical and neurochemical mechanisms within the frontostriatal circuitry. The delicate control of neurotransmitter balance in these circuits and its effects on brain functioning and behavior are not yet fully understood. Studies using different drugs that interfere with this neurotransmitter balance have increased our understanding of the neurobiological regulation of impulse control (e.g. Winstanley 2011; Bari and Robbins 2013; Eagle and Baunez 2010; Dalley and Roiser 2012).

One of the key neurotransmitter systems involved in fronto-striatal physiology is the dopaminergic system originating in the substantia nigra pars compacta ( $\mathrm{SNc}$ ) and ventral tegmental area (VTA)(Gerfen and Surmeier 2011). It is well accepted that dopamine plays an important regulatory role in many forms of impulsivity, especially impulsive action, as is supported by a wealth of preclinical and clinical studies (for a review see e.g. Dalley and Roiser 2012; Winstanley 2011; Dalley et al. 2008; Eagle and Baunez 2010; Dalley et al. 2011; Bari and Robbins 2013; D'Amour-Horvat and Leyton 2014). Psychostimulants such as amphetamine have opposing roles in both types of impulsive action as they improve performance on the stop-signal task (SST; action cancellation) as shown in both healthy rats and humans (de Wit et al. 2000; de Wit et al. 2002; Eagle and Robbins 2003), but impair performance on the choice serial reaction time task (CSRTT; action restraint) in rats (van Gaalen et al. 2006). Of note, the latter has not been tested yet in the CSRTT in healthy humans.

Intracellularly, the effect of dopamine is largely mediated through the cyclic adenosine monophosphate (CAMP)/protein kinase A (PKA) signaling cascade (Nishi et al. 2008; Nishi and Snyder 2010; Nishi et al. 2011; Kuroiwa et al. 2012; Heckman et al. 2016; Nishi and Shuto 2017). This cascade is thus a potential target for pharmacological intervention in several types of impulsivity-related disorders, including ADHD and addiction. Via this cascade the regulatory effect of dopamine on impulsivity can be modulated. The most prominent mean to target CAMP is via specific cyclic nucleotide phosphodiesterases (PDEs)(Beavo 1995; Bender and Beavo 2006). Especially, the PDE4 subfamily is involved in the regulation of dopaminergic cAMP/PKA signaling (Heckman et al. 2016; Richter et al. 2013; Hansen and Zhang 2015). For instance, within the striatum, the synthesis of dopamine by tyrosine hydroxylase (TH) (Harada et al. 1996; Dunkley et al. 2004) and the release of 
dopamine from nigrostriatal dopaminergic terminals (Zhu et al. 2004; Seino and Shibasaki 2005; Schoffelmeer et al. 1985) are regulated by the cAMP/PKA signaling cascade and can be modulated by inhibitors of the PDE4 subfamily (Nishi et al. 2008). Additionally, PDE4 inhibitors modulate dopamine D1-receptor signaling in the frontal cortex, as D1 receptors are $\mathrm{G}_{\mathrm{s}}$-coupled which, in turn, stimulates cAMP (Kuroiwa et al. 2012).

Based on the above, we are interested in the effects of PDE4 inhibition on premature responding in a hypo, normal and hyper dopaminergic state of the brain (see figure 1). As a hypo dopaminergic model we induced a 6-OHDA lesion in the prefrontal cortex, more specifically the infralimbic cortex (IL), which is a well-known animal model for the induction of motor impulsivity related to action restraint as in ADHD (Lukkes et al. 2016; Freund et al. 2014). It has been suggested that the functioning of the areas in the prefrontal cortex is very sensitive to optimal levels of catecholamine (Arnsten 2009). High as well as low catecholamine release in the prefrontal cortex impairs prefrontal cortex function. For the hyperdopaminergic state we also turned to a well-established model of impaired action restraint, namely the systemic administration of d-amphetamine, which has proven to robustly increase premature responding (Winstanley et al. 2006). Taken together, we investigated the effects of the already approved PDE4 inhibitor roflumilast for human administration on premature responding in the CSRTT in a hypo, normal and hyper dopaminergic state of the animal. Main aim of the current study was to evaluate if roflumilast is able to normalize the motor impulsivity deficits induced by a hypo dopaminergic functioning, while probably deteriorating it in a hyper dopaminergic state as roflumilast will increase DA signaling in the frontostriatal circuit.

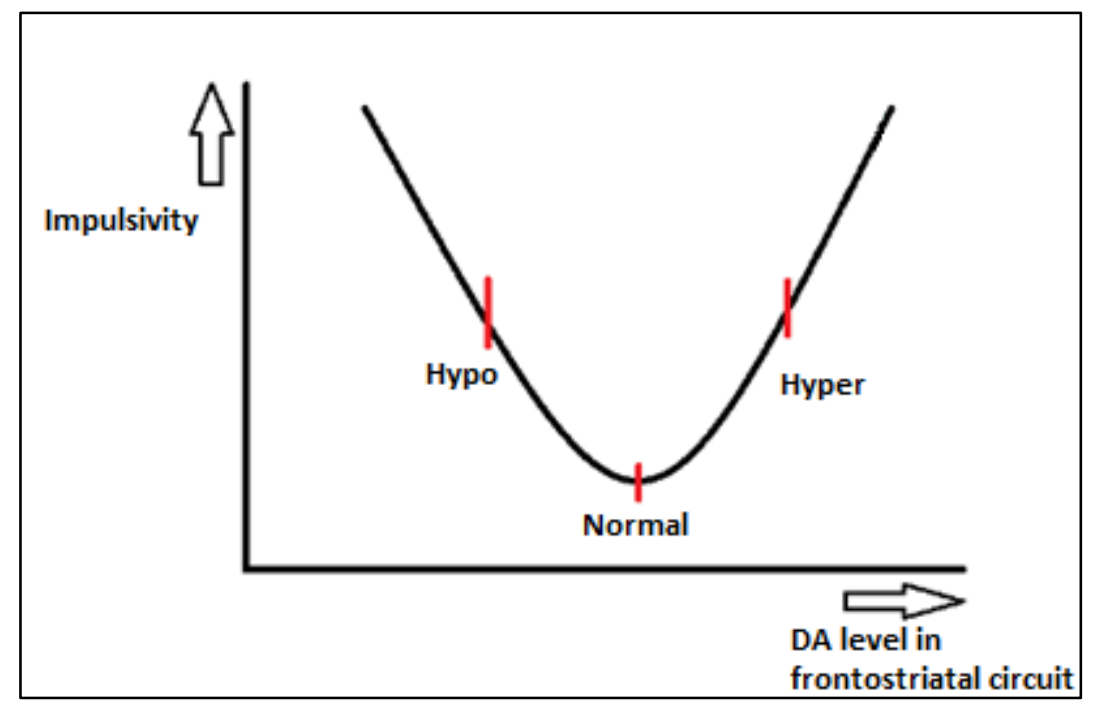

Figure 1. Hypothesized effects of infralimbic dopamine levels on premature responding (action restraint; motor impulsivity); DA=dopamine 


\section{Materials and Methods}

\section{Animals}

All experimental procedures were approved by the local ethical committee for animal experiments of Maastricht University and met governmental guidelines. Sixty 3-month-old male Wistar rats (Charles River, The Netherlands) were used in three separate studies (20 animals per study) with average body weights of $386 \mathrm{~g}( \pm 11.66)$. The animals were housed in pairs in standard Makrolon cages on sawdust bedding in an air-conditioned room (about $20{ }^{\circ} \mathrm{C}$ ). They were kept on a 12/12-h reversed light/dark cycle (lights on from 19:00 $\mathrm{h}$ to 7:00 h). The rats were housed in the same room as where they were tested. A radio, which was playing softly, provided background noise in the room. All testing was done between 9:00 $\mathrm{h}$ and 18:00 $\mathrm{h}$ in a shielded Skinnerbox. Animals had free access to water, but limited food access to reduce their body weight to $90-85 \%$ of their free feeding weight.

\section{Apparatus}

The rats were tested in ten identical operant chambers (inner dimensions: $40 \times 30 \times 33 \mathrm{~cm}$ ), which were equipped with two retractable levers and cue lights just above the levers. A food tray $(5 \times 5 \mathrm{~cm}$ and 2.5 $\mathrm{cm}$ above the grid floor), which was positioned equidistant between the two levers, could be accessed by pushing a hinged panel. The levers $(4 \mathrm{~cm}$ wide) projected $2 \mathrm{~cm}$ into the conditioning chamber and were located $6 \mathrm{~cm}$ from each side of the food tray and $12 \mathrm{~cm}$ above the grid floor. A house light and a loudspeaker were fixed in the ceiling of the conditioning chamber. The operanda and manipulanda in the chambers were controlled by a personal computer and the data were stored on disk at the end of a session.

\section{Experimental procedure}

Magazine (MG) and Continuous reinforcement training (CRF)

Behavioral training started with magazine training (30 min sessions) in which the rats had to learn to push back the hinged panel in order to obtain a food reward ( $45 \mathrm{mg}$ food pellets). The next stage of training consisted of continuous reinforcement training, in which either the left or right lever was inserted in the conditioning chamber after a rat had pressed the hinged panel of the food tray. Whenever a lever was inserted into the chamber the cue light above the lever was switched on. A food reward was provided when a rat had pressed the lever.

\section{Fixed ratio 5 schedule of reward}

Next the rats were trained on a fixed ratio schedule of reinforcement, in which they had to press a lever for five times (FR5) in order to obtain a 45 mg food reward. Reinforcement was continuous; i.e., each set of five lever presses was rewarded. A session was terminated after 60 trials or $30 \mathrm{~min}$, 
whichever applied first. Rats were trained once a day, Monday to Friday, and were given eight FR5 sessions before drug testing started. The measure used to evaluate performance on the FR5 schedule was interresponse time (i.e., time between consecutive lever presses which was averaged for each animal). The purpose of this task was to control for possible effects of any of the pharmaceutical agents used on sensorimotor functioning.

\section{Progressive ratio 10 schedule of reward}

After finishing drug testing in the FR5 task, rats immediately started training on a progressive ratio (PR10) schedule of reinforcement. The rats had to progressively increase the response requirement (steps of ten lever presses) to obtain a food reward. For the first food pellet they were required to press ten times, for the next reinforcement they had to press the lever twenty times, and so on. A session was terminated if a rat did not press the lever for $3 \mathrm{~min}$. Rats were trained once a day, Monday to Friday, and were given eight PR10 sessions before drug testing started. The measure used to evaluate performance in the PR10 task was the breakpoint (i.e., total number of lever presses made during a session). The purpose of this task was to control for possible effects of any of the pharmaceutical agents used on food motivation.

\section{Choice serial reaction time task (CSRTT; Figure 2)}

Subsequently, rats did the CSRTT to test the effects of the PDE4 inhibitor on premature responding (Blokland 1998). In the CSRTT rats had to push the panel for a longer duration until one of the levers was made accessible. First, a randomly chosen duration of $0.5-1.0 \mathrm{~s}$ (steps of $0.1 \mathrm{~s}$ ) was used. This variable period was called the hold duration. Also, an auditory stimulus was presented when the hold duration had elapsed. A high tone $(10 \mathrm{kHz} ; 80 \mathrm{~dB})$ predicted insertion of the left lever, and a low tone $(2.5 \mathrm{kHz} ; 80 \mathrm{~dB})$ predicted the insertion of the right lever. The insertion of the lever took about $2 \mathrm{~s}$. This tone was turned off when the rat withdrew its nose from the food tray. When a rat did not succeed in pressing the panel for the entire hold duration (premature response), the same interval was started again upon pressing the panel. After the rats showed a steady performance during this stage they were required to push the panel for a randomly chosen duration of $0.5-1.5 \mathrm{~s}$ (steps of 0.1 s). These hold durations were used during all further testing. The inter-trial interval was $10 \mathrm{~s}$. A session lasted $30 \mathrm{~min}$ or until a rat had completed 60 trials. After the rats showed a stable performance, which occurred after about 2 weeks of training in this task, the rats were subjected to the main test paradigm (drug treatment).

The following parameters were used to evaluate the responding of the rats: 
Reaction time $(R T)$ : the main latency between the onset of the tone and the release of the hinged food tray panel (after pushing it away). It is generally accepted that response latencies shorter than 100 ms may not reflect true RT (Blokland and Honig 1999). These latencies were counted as premature responses. Response latencies longer than $1500 \mathrm{~ms}$ were not considered to be a taskrelated RT. The RT performance was evaluated in two ways: the mean reaction time of all responses and the mean RT per hold duration was examined.

Motor time (MT): the mean latency between the release of the hinged food tray panel and the lever press. It was assumed that MT of more than $2 \mathrm{~s}$ do not reflect true MT (Blokland and Honig 1999).

Number of trials: the total number of trials the rats completed in a session of maximum $30 \mathrm{~min}$.

Premature responses $(P R)$ : the total number of times that the rat released the hinged panel before the hold duration had elapsed. In the present study, we always used the ratio of PR (i.e., the PR divided by the total number of completed trials, with a maximum of 60 ). Furthermore, a PR caused the trial to start over again.

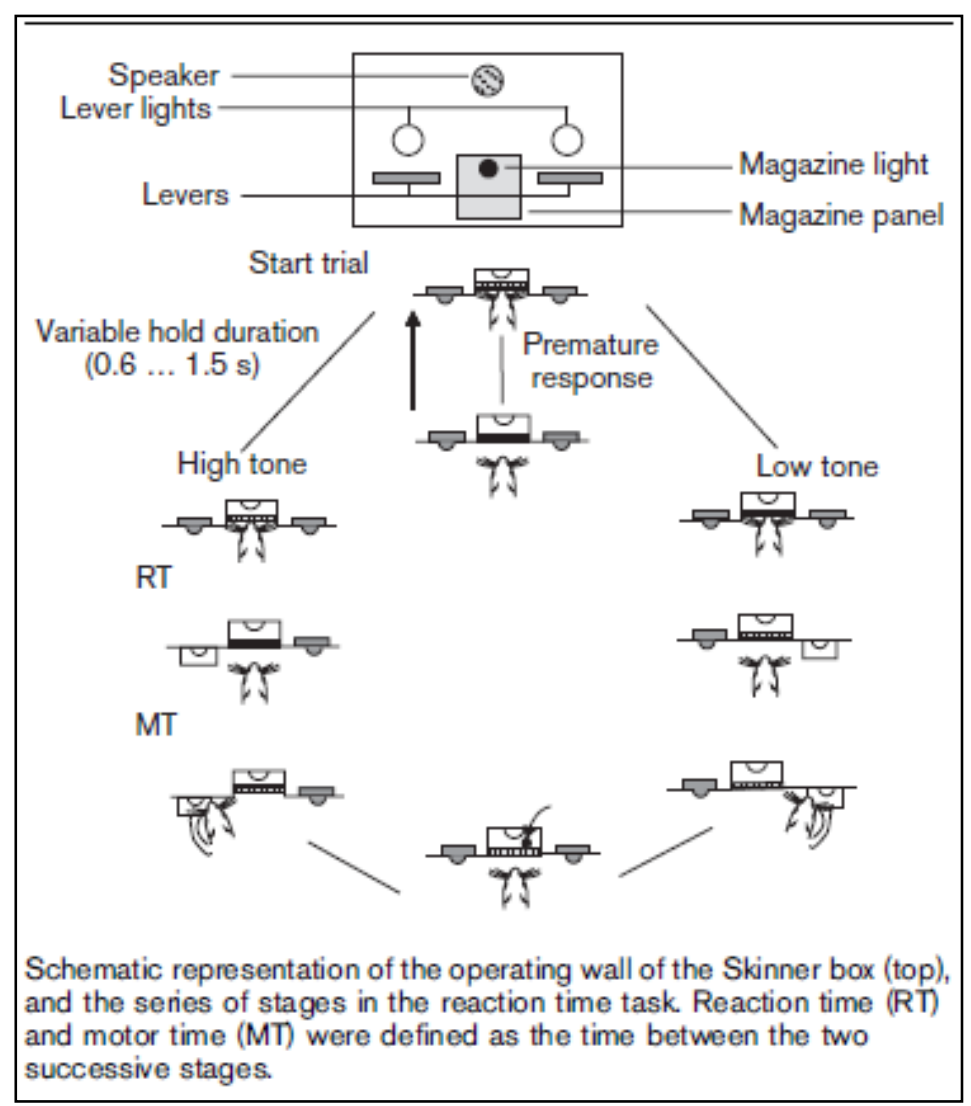

Figure 2. Schematic representation of the operating wall of the Skinner box (top), and the series of stages in the reaction time task. Reaction time (RT) and motor time (MT) were defined as the time between the two successive stages (adopted with permission from Blokland, Sik and Lieben, 2005). 


\section{Treatment}

The PDE4 inhibitor roflumilast (kindly donated by Takeda, Konstanz, Germany) was tested in the FR5, PR10 and CSRTT. Roflumilast was freshly dissolved on the day of testing. Drug administration of the PDE inhibitor occurred 30 min prior to behavioral testing for all three paradigms (FR5, PR10 and CSRTT) in all three studies (hypo, hyper and normal dopaminergic state of the animal) and was done intraperitoneally (i.p.) for roflumilast $(0.001,0.003,0.01,0.03$ and $0.1 \mathrm{mg} / \mathrm{kg})$. The PDE inhibitor was dissolved in the same vehicle (98\% methyl cellulose [tylose] solution (0.5\%) and $2 \%$ tween 80 ) and administered in a volume of $1 \mathrm{ml} / \mathrm{kg}$ (i.p.). In the second study, the hyper dopaminergic state was induced by administration of d-amphetamine (Sigma Aldrich, Zwijndrecht, The Netherlands). dAmphetamine was administered i.p. 30 min before behavioral testing started $(1.0 \mathrm{mg} / \mathrm{kg})$ in an injection volume of $1 \mathrm{ml} / \mathrm{kg}$. In the third study, a hypo dopaminergic state was induced in the IL as explained below.

\section{Stereotactic surgery (study 3; 6-OHDA lesions)}

In the third study, the effects of the PDE4 inhibitor roflumilast were tested in a hypo dopaminergic state of the IL. The hypo dopaminergic state was induced by means of 6-hydroxydopamine (6-OHDA) lesions. The animals $(n=10)$ received stereotactic injections of $2 \mu \mathrm{l} 6-\mathrm{OHDA}(5 \mu \mathrm{g} / \mu \mathrm{l}$ dissolved in $0.9 \%$ saline and $0.2 \%$ ascorbic acid; Sigma Aldrich, Zwijndrecht, The Netherlands) or the same injection amount of the vehicle solution ( $n=10 ; 0.9 \%$ saline and $0.2 \%$ ascorbic acid) at four sites (two per hemisphere) in the IL. One hour before the surgery, rats received desipramine (30 mg/kg in $0.9 \%$ saline, injection volume $1 \mathrm{mg} / \mathrm{kg}$ i.p.). Desipramine was administered to protect noradrenergic neurons from possible damage by 6-OHDA and thus make the lesion more DA specific (Mason and Fibiger 1979). The animals were anaesthetized using isoflurane (induction 5\%, maintenance $2 \%$ ) and subsequently placed in a stereotactic frame. Surgery site was pretreated with lidocaine for local anesthesia. Corneal dehydration was prevented by applications of Vaseline. Body temperature was maintained at $37 \pm 0.5^{\circ} \mathrm{C}$ using a homeothermic heating blanket (Harvard Apparatus, Kent, UK). The injections of 6-OHDA or vehicle were performed in the IL at the following coordinates (Paxinos et al. 2009): AP: $+3.2 \mathrm{~mm}, \mathrm{~L}: 0.6$ and $-0.6 \mathrm{~mm}$, and DV: -4.8 and $-5.4 \mathrm{~mm}$ (from bregma). Injection speed was $0.5 \mathrm{\mu l} / \mathrm{min}$ and the cannula was left in place for an additional 2 min before slowly retracting it. Pre-operatively and 8 hours post-operatively, Temgesic $(0.05 \mathrm{mg} / \mathrm{kg})$ was administered subcutaneous as analgesic. The animals were put back in their home cages for recovery, and weighted and handled daily. The animals had free access to food and water after surgery. Food and water was consumed without problems. Based on effects on performance, 5 out of 10 animals were selected to proceed with the roflumilast testing in the 6-OHDA condition. 


\section{Statistics}

Statistical analysis was carried out using IBM SPSS Statistics 24 software (IBM, Portsmouth, UK). The raw data were checked for outliers using SPSS descriptive statistics and checked for normality of distribution. Paired samples T-test, GLM univariate ANOVA as well as GLM one-way repeated measures analysis of variance (ANOVA) followed by Sidak's post-hoc test was used. For the paired samples T-test equal variances were assumed unless the Levene's test for equality of variances was significant. P-values were corrected for multiple testing. Data are depicted as means \pm SEM.

\section{Results}

\section{Fixed ratio 5 schedule of reward}

All animals completed the 60 trials within 30 minutes. Roflumilast, $d$-amphetamine and the IL 6OHDA lesion did not affect the inter-response time in the FR5 schedule of reward (data not shown).

\section{Progressive ratio 10 schedule of reward}

Roflumilast, d-amphetamine and the IL 6-OHDA lesion did not affect the breakpoint in the progressive ratio 10 schedule of reward (data not shown).

\section{Choice serial reaction time task}

\section{Reaction times}

For the hypo dopaminergic state, the mixed model ANOVA showed no significant dose $\mathrm{x}$ lesion interaction effect $(F(3,55)=0.434$, N.S. $)$. Also, there was no main effect of dose $(F(3,55)=0.751, N . S$. $)$ or lesion $(F(1,55)=0.259$, N.S.)(see figure $3 A)$. There was no significant effect of roflumilast on the reaction times in a normal dopaminergic state $(F(3,27)=0.632$, N.S.; see figure $3 B)$. Surprisingly, in the hyper dopaminergic state, treatment with $d$-amphetamine only showed a trend toward significance to affect the reaction times $(t(19)=1.813 ; p=0.08)$ (see figure $3 C$ ). Roflumilast did not show any effect on the reaction times $(F(4,76)=0.875$, N.S.; see figure $3 C)$. 
Hypo dopaminergic state

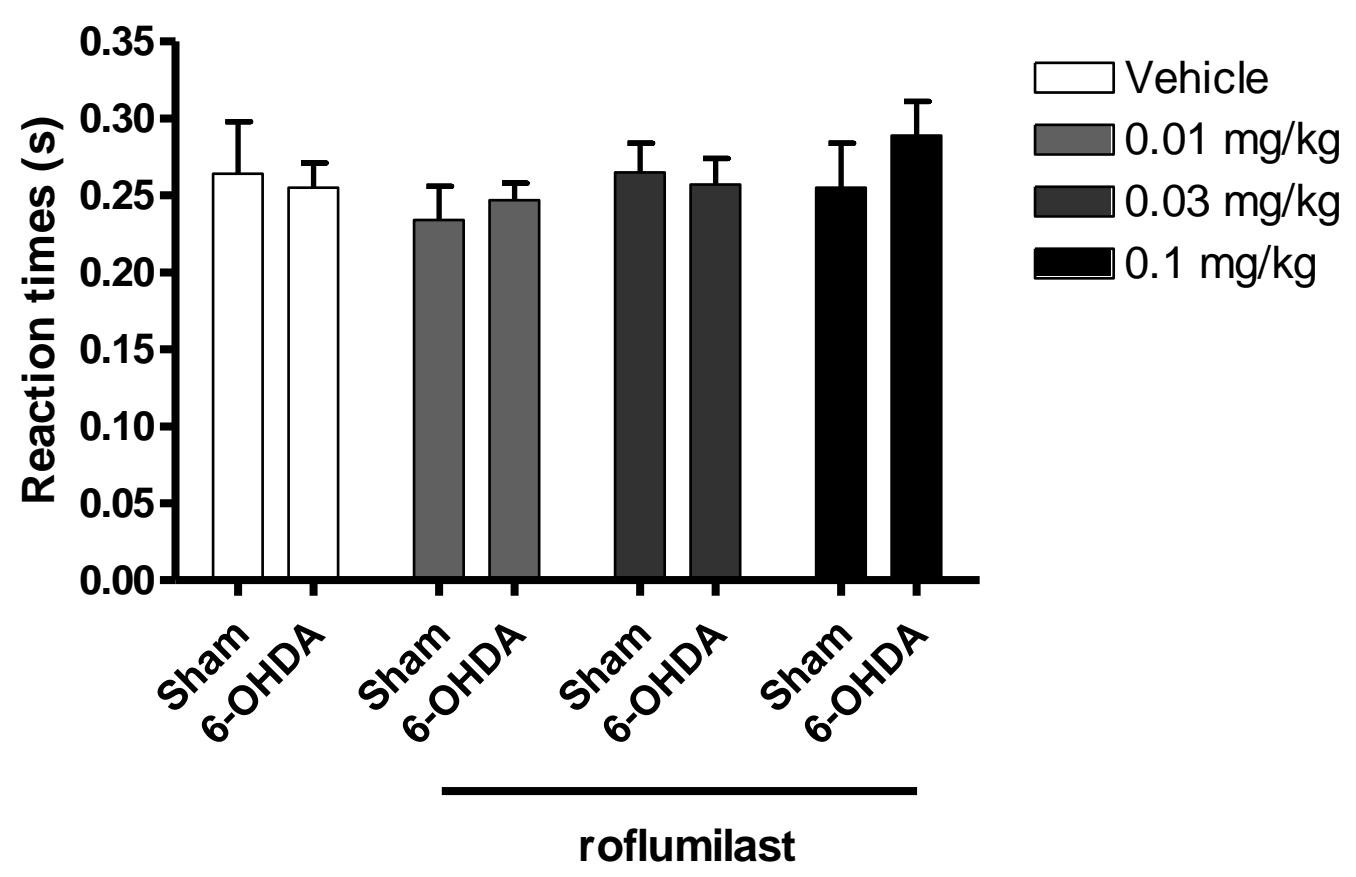

Normal dopaminergic state

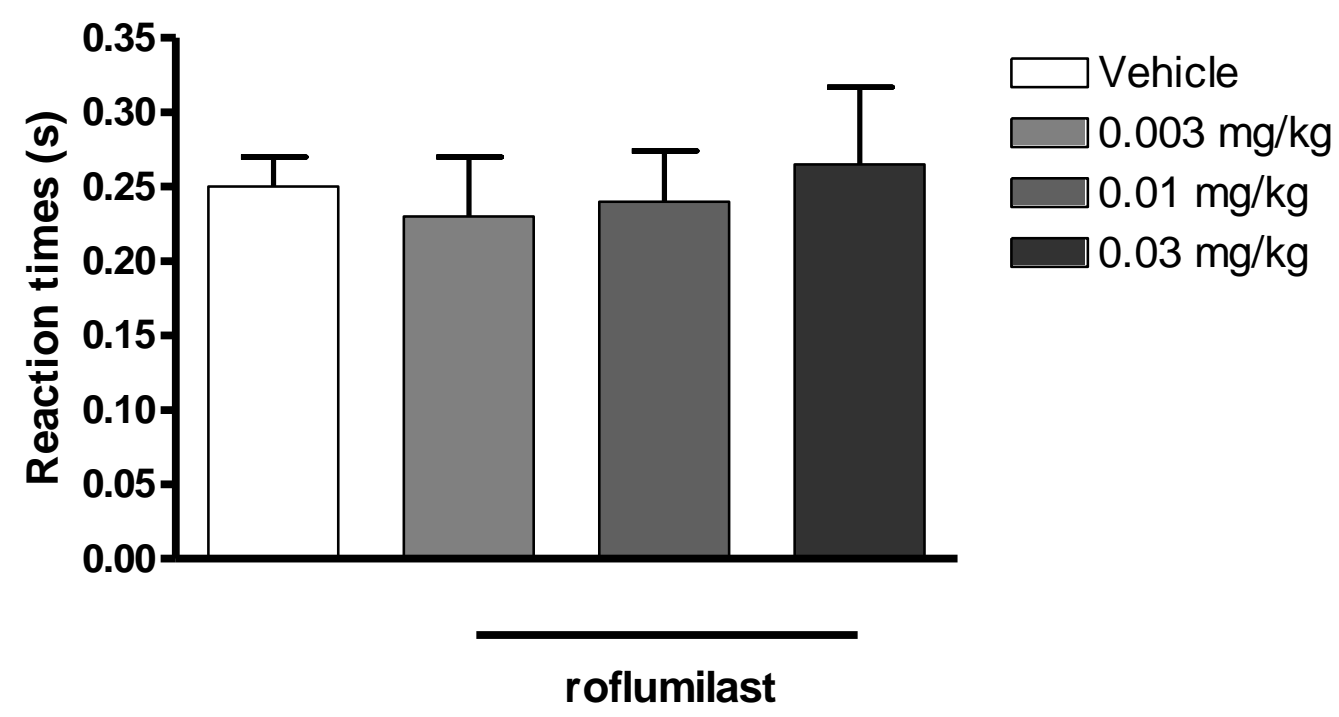




\section{Hyper dopaminergic state}

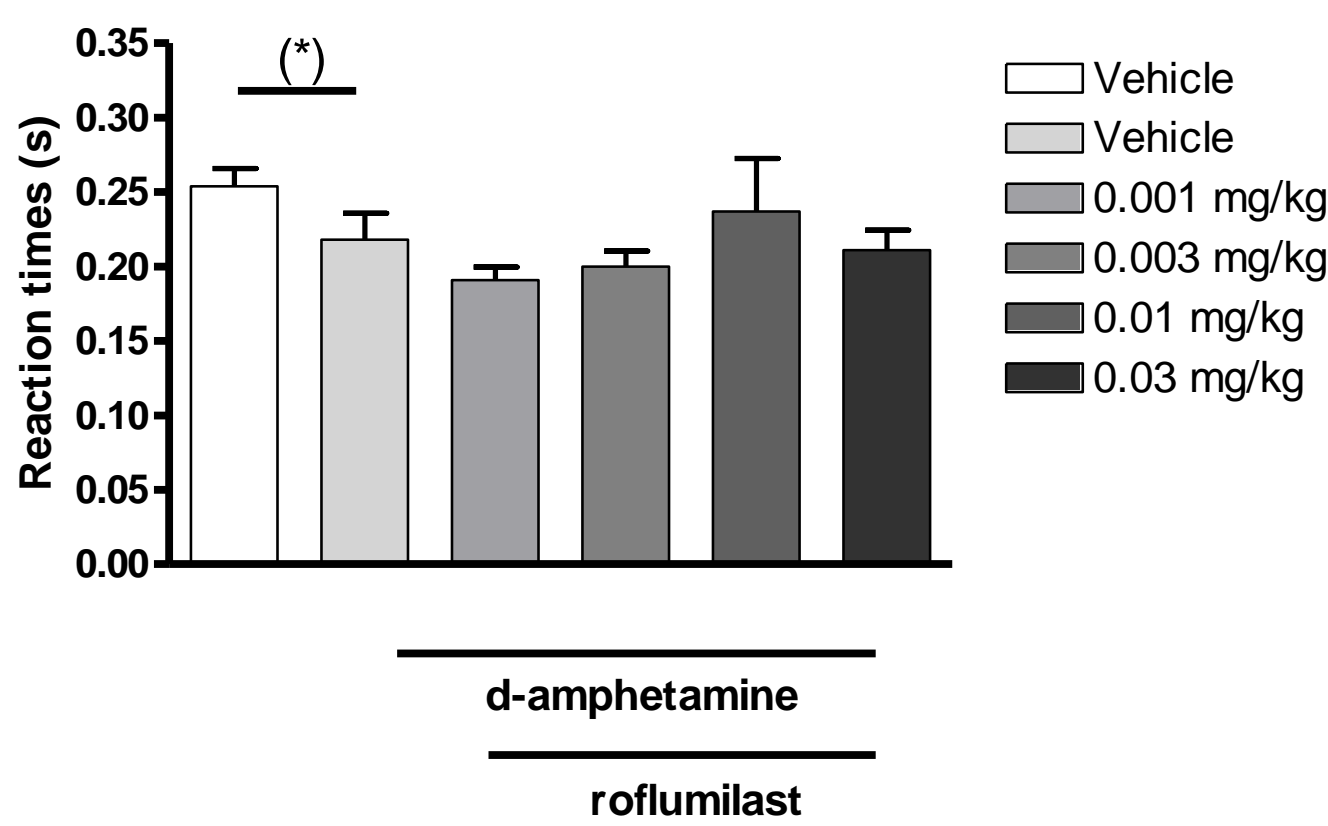

Figure 3. Effects of the PDE4 inhibitor roflumilast on reaction times (s) in the CSRTT in a hypo (A) and hyper (B) dopaminergic model of motor impulsivity (action restraint). $(*)=p=0.08$

\section{Motor times}

Roflumilast, $d$-amphetamine and the IL 6-OHDA lesion did not affect the motor times in the CSRTT (data not shown).

\section{Premature responses}

For the hypo dopaminergic state, the mixed model ANOVA showed no significant dose $\mathrm{x}$ lesion interaction effect $(F(3,48)=1.289$, N.S. $)$. Also, there was no main effect of dose $(F(3,48)=0.367$, N.S. $)$. However, there was a significant main effect of lesion (sham vs. $6-$ OHDA; $F(1,48)=18.526, p<0.001$; see figure 4A). Subsequently, we checked for differences between sham and 6-OHDA lesion per dose of roflumilast. For the $0.01 \mathrm{mg} / \mathrm{kg}(\mathrm{t}(13)=2.384 ; \mathrm{p}<0.05)$ and $0.1 \mathrm{mg} / \mathrm{kg}(\mathrm{t}(4.261)=3.944 ; \mathrm{p}<0.05)$ dosages the 6-OHDA lesioned animals showed significantly higher percentages of premature responses (see figure 4A; Sidak correction for multiple testing). Treatment with $0.03 \mathrm{mg} / \mathrm{kg}$ of roflumilast normalized the premature responding of the 6-OHDA lesioned animals to the level of sham lesioned animals ( $\mathrm{t}(13)=0.586 ;$ N.S.). 
There was no significant effect of roflumilast on the percentage of premature responses in a normal dopaminergic state $(F(3,27)=0.723$, N.S.; figure $4 B)$.

In the hyper dopaminergic state, treatment with d-amphetamine increased the percentage of premature responses $(t(18)=-4.748 ; p<0.001)$. Subsequent treatment with roflumilast further increased the percentage of premature responses as indicated by the overall treatment effect ( $F$ $(4,76)=3.370, p<0.01$; figure $4 C$ ). Post-hoc analyses (Sidak) revealed a significant increase in premature responding at the $0.01 \mathrm{mg} / \mathrm{kg}$ dose compared to amphetamine alone (figure $4 \mathrm{C} ; \mathrm{p}<0.01$ ).

\section{Hypo dopaminergic state}

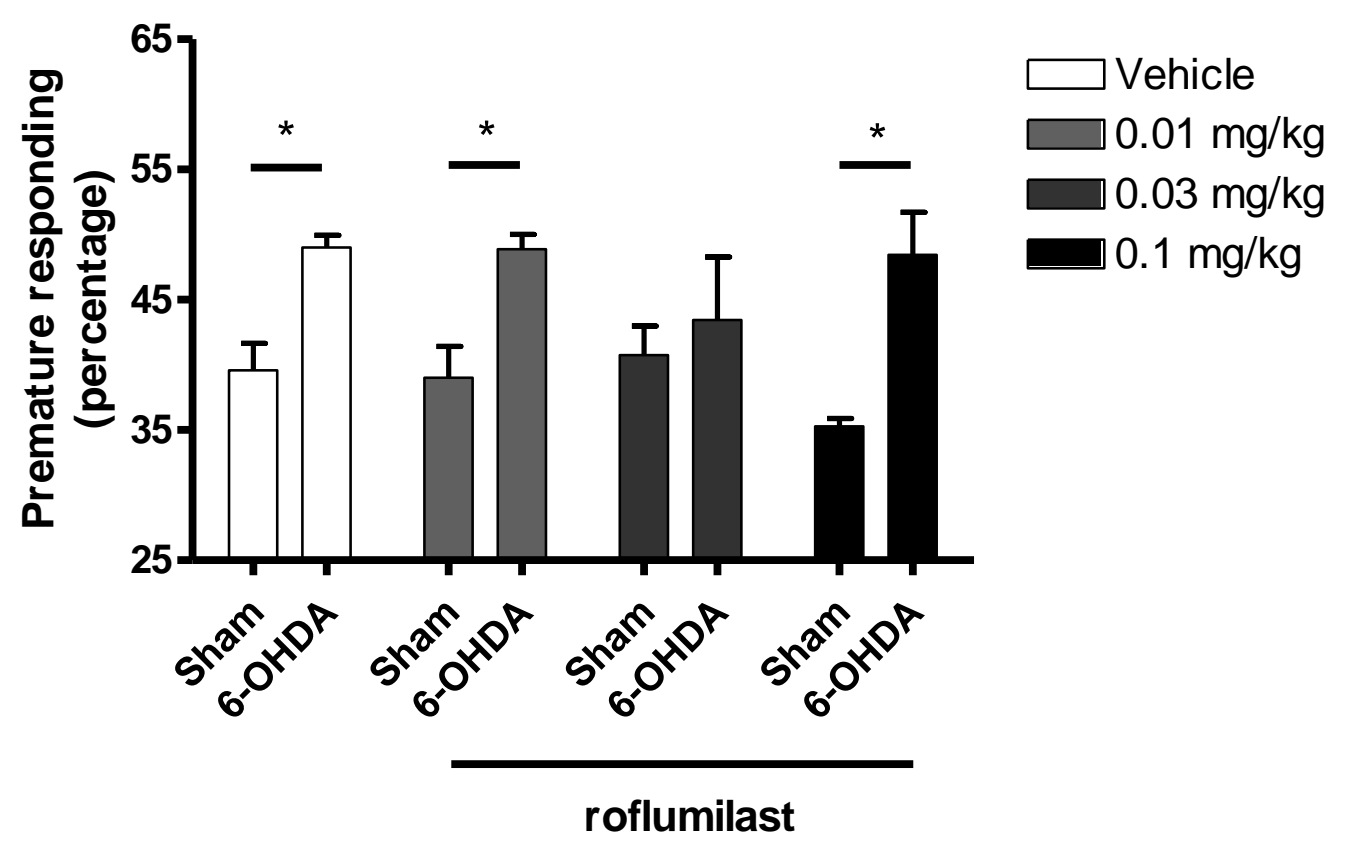




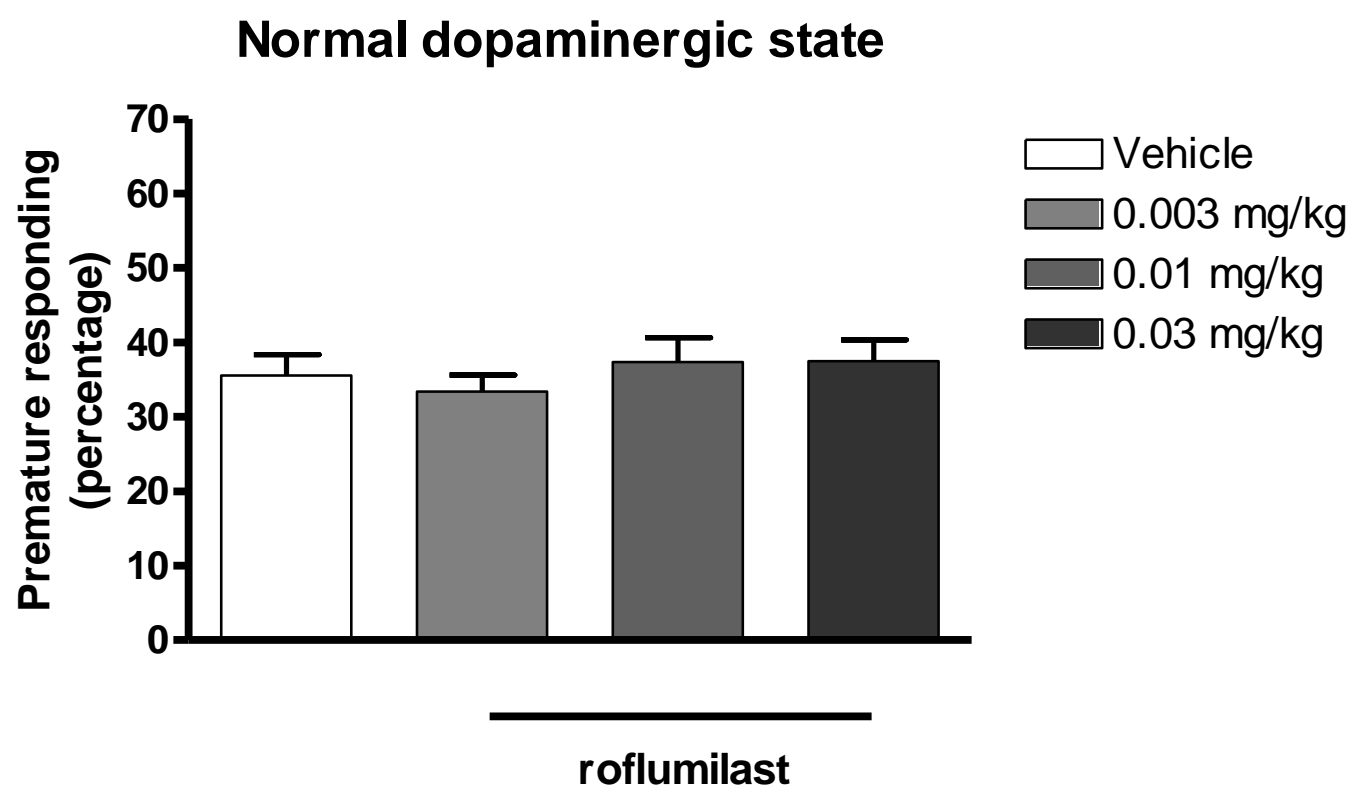

Hyper dopaminergic state

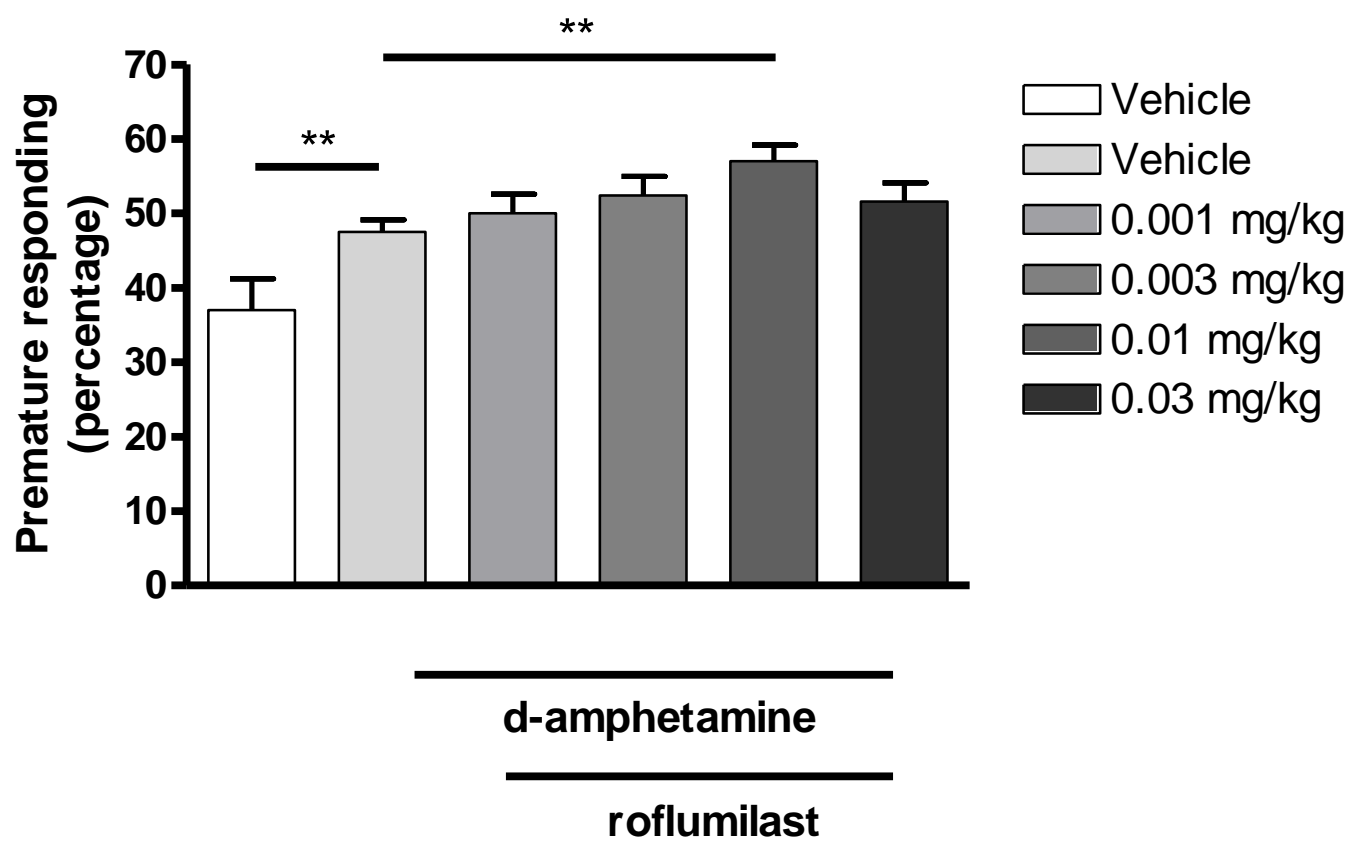

Figure 4. Effects of the PDE4 inhibitor roflumilast on premature responding in the CSRTT in a hypo (A), normal (B) and hyper (C) dopaminergic model of motor impulsivity (action restraint). ${ }^{*}=p<0.05 ;{ }^{* *}=p<0.01$ 


\section{Discussion}

The aim of the current study was to investigate the effects of the, for chronic obstructive pulmonary disease (COPD), clinically approved PDE4 inhibitor roflumilast on premature responding in the CSRTT in a hypo, normal and hyper dopaminergic state of the cognitive fronto-striatal circuit. Premature responding was used as a measure for action restraint, one of the two types of motor impulsivity. It was first checked whether the different treatments (i.e., amphetamine, IL 6-OHDA lesions, roflumilast) had an effect on sensorimotor functioning (FR5) and food motivation (PR10). None of the treatments showed any effect on these basic response rates in the operant chamber. Therefore, treatment effects in the CSRTT cannot be explained by differences in lever press responding or food motivation. In line with the notion of a $\mathrm{U}$-shaped relation between dopamine and impulsive responding (Arnsten 2009), we found that both increasing and decreasing dopamine levels (by amphetamine and IL 6-OHDA lesion, respectively) resulted in an increase in premature responding in the CSRTT. Thus, interestingly, these results followed the U-shaped dose-response curve seen in figure 1. This finding indicates that $6-\mathrm{OHDA}$ as well as d-amphetamine is a suitable tool to induce models of dopamine-related motor impulsivity (action restraint).

The release of dopamine from dopaminergic terminals is regulated by the CAMP signaling cascade and can be modulated by inhibitors of the PDE4 subfamily (Schoffelmeer et al. 1985; Nishi et al. 2008). Therefore, in the hypo dopaminergic state of the fronto-striatal circuit, the PDE4 inhibitor roflumilast was expected to enhance the release of dopamine, restoring low levels of dopamine to their original level. Linked to this assumption, treating the 6-OHDA lesioned animals with roflumilast indeed restored the level of premature responding back to the level of the sham-lesioned animals. Additionally, also following our hypothesis, roflumilast further increased the already heightened level of premature responding in the hyper dopaminergic state of the fronto-striatal circuit, induced by damphetamine. Thus, we again observed a shift to the right on the U-shaped dose-response curve. However, in the normal (untreated) dopaminergic state roflumilast did not exhibit any effects on the level of premature responding. Based on results of the current study, roflumilast thus seems to follow our hypothesis based on the dopaminergic dose-response curve except for the non-modulated dopaminergic condition. Possibly due to its effects on dopamine release, roflumilast seems to enhance the effects of dopamine (as was shown before by Nishi and Snyder 2010; Schoffelmeer et al. 1985), restoring depleted levels and further enhancing already heightened levels of dopamine. As a result, it would be interesting to test the effects of PDE4 inhibition in disorders characterized by impaired action restraint related to fronto-striatal hypodopaminergia like ADHD. 
However, several points remain in need of further clarification/investigation. First of all, we observed no effects of roflumilast on premature responding in the normal dopaminergic state of the frontostriatal circuit. This could be explained by the fact that the brain has a higher level of compensatory ability when catecholamine levels are at an optimum (or near optimum) level. On the other hand, it could also be that, since roflumilast affects the release of dopamine, the effects of roflumilast are most easily observed in experimental conditions in which a dopaminergic challenge is present (6OHDA or d-amphetamine). It also seems likely that the peak of the U-shaped curve is rather wide due to compensatory mechanisms of the organism in physiological conditions. Thus, it could also just be that roflumilast shifted the performance on the U-shaped dose response curve from slightly left of the optimum to slightly right of the optimum while behavioral output remains unchanged. Only in pathophysiological conditions, when performance lies outside this compensatory window, a change in performance can be observed.

Pharmacokinetics of roflumilast have been established in previous studies by our group (Vanmierlo et al. 2016) and others (Jabaris et al. 2015) showing that roflumilast is brain penetrant and cognitively active. But despite brain penetration, a point of attention is that expression levels of the target of roflumilast, i.e. PDE4 itself, in the IL are currently unknown as are the expression levels at other key structures within the fronto-striatal circuitry, e.g. nigral and pallidal areas or the subthalamic nucleus. Finally, we like to discuss the fact that our findings in the hypo dopaminergic state of the IL, showed no significant interaction effect. This might be due to the high number of groups being tested occluding possible interaction effects. Importantly, on closer inspection we found no effects of roflumilast in the sham-lesioned animals as is in line with our findings in the normal dopaminergic state, while the 6-OHDA lesioned animals normalized their premature responding after treatment with an acute dose of $0.03 \mathrm{mg} / \mathrm{kg}$ roflumilast. Possibly, the lack of an overall roflumilast effect might be explained by the severity of the 6-OHDA lesion. Based on previous experience in our department, we used relatively high doses of 6-OHDA that induce reliable lesions in the striatum to mimic Parkinson's disease (Scholtissen et al. 2006). However, to our knowledge no literature exists regarding the exact dose of 6-OHDA to be used in the IL (e.g. Lukkes et al. 2016; Freund et al. 2014). Possibly, the strong lesions were not easily reversed by other doses besides the cognitively effective dose of roflumilast (Vanmierlo et al. 2016).

To our knowledge, the only other study investigating the effects of a PDE inhibitor on impulsivity is a study recently published using the PDE10 inhibitor TAK-063 (Suzuki et al. 2015). Based on the almost exclusive expression of PDE10 in the striatum (Lakics et al. 2010) and the preferential expression in the indirect D2 pathway, we hypothesize that a PDE10 inhibitor does the opposite of a PDE4 inhibitor 
and should shift performance in the CSRTT to the left on the U-shaped dose-response curve. In contrast to our hypothesis, the PDE10 inhibitor TAK-063 showed positive effects in healthy animals. However, it should be noted that, as explained above, not all healthy subjects perform exactly at an optimal level on the U-shaped dose response curve. If a batch of animals or group of participants performs slightly right from the optimal performance on the U-shaped dose response curve, a shift to the left side may be beneficial. Therefore, it would be interesting to add next to a PDE4 inhibitor, a PDE10 inhibitor or PDE1 inhibitor, which has also high expression in the fronto-striatal brain areas, as references in future studies to obtain a more complete picture, especially when testing healthy animals.

Taken together, the current study looked at the unique role of the dopaminergic modulation of premature responding and investigated the mediating role of PDE4 by testing the effects of roflumilast in a hypo, normal and hyper dopaminergic state of the cognitive fronto-striatal circuit. Results indicate a role for PDE4 inhibitors in shifting performance on premature responding to the right on the U-shaped dose response curve. As a result, it would be interesting to test the effects of PDE4 inhibition in disorders affected by disrupted impulse control related to fronto-striatal hypodopaminergia including ADHD. 


\section{Acknowledgements}

PRAH is financially supported by the Human Enhancement and Learning (HEaL) initiative of Maastricht University.

\section{Statement of interest}

$A B$ and JP have a proprietary interest in the PDE4 inhibitor roflumilast. 


\section{References}

Alexander GE, DeLong MR, Strick PL (1986) Parallel organization of functionally segregated circuits linking basal ganglia and cortex. Annu Rev Neurosci 9 (1):357-381

Arnsten AF (2009) Toward a new understanding of attention-deficit hyperactivity disorder pathophysiology: an important role for prefrontal cortex dysfunction. CNS Drugs 23 Suppl 1:33-41. doi:10.2165/00023210-200923000-00005

Aron AR (2007) The neural basis of inhibition in cognitive control. Neuroscientist 13 (3):214-228. doi:10.1177/1073858407299288

Aron AR, Poldrack RA (2005) The cognitive neuroscience of response inhibition: relevance for genetic research in attention-deficit/hyperactivity disorder. Biol Psychiatry 57 (11):1285-1292. doi:10.1016/j.biopsych.2004.10.026

Bari A, Robbins TW (2013) Inhibition and impulsivity: behavioral and neural basis of response control. Prog Neurobiol 108:44-79. doi:10.1016/j.pneurobio.2013.06.005

Beavo JA (1995) Cyclic nucleotide phosphodiesterases: functional implications of multiple isoforms. Physiol Rev 75 (4):725-748

Bellgrove MA, Chambers CD, Vance A, Hall N, Karamitsios M, Bradshaw JL (2006) Lateralized deficit of response inhibition in early-onset schizophrenia. Psychol Med 36 (4):495-505. doi:10.1017/s0033291705006409

Bender AT, Beavo JA (2006) Cyclic nucleotide phosphodiesterases: molecular regulation to clinical use. Pharmacol Rev 58 (3):488-520. doi:10.1124/pr.58.3.5

Blokland A (1998) Reaction time responding in rats. Neurosci Biobehav Rev 22 (6):847-864

Blokland A, Honig W (1999) Intra-striatal haloperidol and scopolamine injections: effects on choice reaction time performance in rats. Eur Neuropsychopharmacol 9 (6):523-531

Blokland A, Sik A, Lieben C (2005) Evaluation of DOI, 8-OH-DPAT, eticlopride and amphetamine on impulsive responding in a reaction time task in rats. Beh Pharm 6 (2):93-100

Calabresi P, Gubellini P, Centonze D, Picconi B, Bernardi G, Chergui K, Svenningsson P, Fienberg AA, Greengard P (2000) Dopamine and CAMP-regulated phosphoprotein 32 kDa controls both striatal long-term depression and long-term potentiation, opposing forms of synaptic plasticity. J Neurosci 20 (22):8443-8451

Calabresi P, Picconi B, Tozzi A, Ghiglieri V, Di Filippo M (2014) Direct and indirect pathways of basal ganglia: a critical reappraisal. Nat Neurosci 17 (8):1022-1030. doi:10.1038/nn.3743

Cardinal RN, Winstanley CA, Robbins TW, Everitt BJ (2004) Limbic corticostriatal systems and delayed reinforcement. Ann N Y Acad Sci 1021:33-50. doi:10.1196/annals.1308.004

Chudasama Y, Robbins TW (2006) Functions of frontostriatal systems in cognition: comparative neuropsychopharmacological studies in rats, monkeys and humans. Biol Psychol 73 (1):19-38. doi:10.1016/j.biopsycho.2006.01.005

D'Amour-Horvat V, Leyton M (2014) Impulsive actions and choices in laboratory animals and humans: effects of high vs. low dopamine states produced by systemic treatments given to neurologically intact subjects. Front Behav Neurosci 8:432. doi:10.3389/fnbeh.2014.00432

Dalley JW, Everitt BJ, Robbins TW (2011) Impulsivity, compulsivity, and top-down cognitive control. Neuron 69 (4):680-694. doi:10.1016/j.neuron.2011.01.020

Dalley JW, Mar AC, Economidou D, Robbins TW (2008) Neurobehavioral mechanisms of impulsivity: fronto-striatal systems and functional neurochemistry. Pharmacol Biochem Behav 90 (2):250260. doi:10.1016/j.pbb.2007.12.021

Dalley JW, Robbins TW (2017) Fractionating impulsivity: neuropsychiatric implications. Nat Rev Neurosci 18 (3):158-171. doi:10.1038/nrn.2017.8

Dalley JW, Roiser JP (2012) Dopamine, serotonin and impulsivity. Neuroscience 215:42-58. doi:10.1016/j.neuroscience.2012.03.065

de Wit H, Crean J, Richards JB (2000) Effects of d-amphetamine and ethanol on a measure of behavioral inhibition in humans. Behav Neurosci 114 (4):830-837

de Wit H, Enggasser JL, Richards JB (2002) Acute administration of d-amphetamine decreases impulsivity in healthy volunteers. Neuropsychopharmacology 27 (5):813-825. doi:10.1016/s0893-133x(02)00343-3

Dunkley PR, Bobrovskaya L, Graham ME, von Nagy-Felsobuki El, Dickson PW (2004) Tyrosine hydroxylase phosphorylation: regulation and consequences. J Neurochem 91 (5):1025-1043. doi:10.1111/j.1471-4159.2004.02797.x 
Durston S, Fossella JA, Mulder MJ, Casey BJ, Ziermans TB, Vessaz MN, Van Engeland H (2008) Dopamine transporter genotype conveys familial risk of attention-deficit/hyperactivity disorder through striatal activation. J Am Acad Child Adolesc Psychiatry 47 (1):61-67. doi:10.1097/chi.0b013e31815a5f17

Eagle DM, Baunez C (2010) Is there an inhibitory-response-control system in the rat? Evidence from anatomical and pharmacological studies of behavioral inhibition. Neurosci Biobehav Rev 34 (1):50-72. doi:10.1016/j.neubiorev.2009.07.003

Eagle DM, Robbins TW (2003) Inhibitory control in rats performing a stop-signal reaction-time task: effects of lesions of the medial striatum and d-amphetamine. Behav Neurosci 117 (6):13021317. doi:10.1037/0735-7044.117.6.1302

Evenden JL (1999) Varieties of impulsivity. Psychopharmacology (Berl) 146 (4):348-361

Fillmore MT, Rush CR (2002) Impaired inhibitory control of behavior in chronic cocaine users. Drug Alcohol Depend 66 (3):265-273

Fillmore MT, Rush CR, Hays L (2002) Acute effects of oral cocaine on inhibitory control of behavior in humans. Drug Alcohol Depend 67 (2):157-167

Fillmore MT, Rush CR, Hays L (2006) Acute effects of cocaine in two models of inhibitory control: implications of non-linear dose effects. Addiction 101 (9):1323-1332. doi:10.1111/j.13600443.2006.01522.x

Freund N, MacGillivilray HT, Thompson BS, Lukkes JL, Stanis JJ, Brenhouse HC, Andersen SL (2014) Sex-dependent changes in ADHD-like behaviors in juvenile rats following cortical dopamine depletion. Behav Brain Res 270:357-363. doi:10.1016/j.bbr.2014.05.024

Gauggel S, Rieger M, Feghoff TA (2004) Inhibition of ongoing responses in patients with Parkinson's disease. J Neurol Neurosurg Psychiatry 75 (4):539-544

Gerfen CR, Surmeier DJ (2011) Modulation of striatal projection systems by dopamine. Annu Rev Neurosci 34:441-466. doi:10.1146/annurev-neuro-061010-113641

Haber SN, Rauch SL (2010) Neurocircuitry: a window into the networks underlying neuropsychiatric disease. Neuropsychopharmacology 35 (1):1-3. doi:10.1038/npp.2009.146

Hansen RT, 3rd, Zhang HT (2015) Phosphodiesterase-4 modulation as a potential therapeutic for cognitive loss in pathological and non-pathological aging: possibilities and pitfalls. Curr Pharm Des 21 (3):291-302

Harada, Wu J, Haycock JW, Goldstein M (1996) Regulation of L-DOPA biosynthesis by site-specific phosphorylation of tyrosine hydroxylase in AtT-20 cells expressing wild-type and serine 40substituted enzyme. J Neurochem 67 (2):629-635

Heckman PR, van Duinen MA, Bollen EP, Nishi A, Wennogle L, Blokland A, Prickaerts J (2016) Phosphodiesterase inhibition and regulation of dopaminergic frontal and striatal functioning: clinical implications. Int J Neuropsychopharmacol. doi:10.1093/ijnp/pyw030

Jabaris SG, Sumathy H, Kumar RS, Narayanan S, Thanikachalam S, Babu CS (2015) Effects of rolipram and roflumilast, phosphodiesterase-4 inhibitors, on hypertension-induced defects in memory function in rats. Eur J Pharmacol 746:138-147. doi:10.1016/j.ejphar.2014.10.039

Kuroiwa M, Snyder GL, Shuto T, Fukuda A, Yanagawa Y, Benavides DR, Nairn AC, Bibb JA, Greengard P, Nishi A (2012) Phosphodiesterase 4 inhibition enhances the dopamine D1 receptor/PKA/DARPP-32 signaling cascade in frontal cortex. Psychopharmacology (Berl) 219 (4):1065-1079. doi:10.1007/s00213-011-2436-8

Lakics V, Karran EH, Boess FG (2010) Quantitative comparison of phosphodiesterase mRNA distribution in human brain and peripheral tissues. Neuropharmacology 59 (6):367-374. doi:10.1016/j.neuropharm.2010.05.004

Lukkes JL, Freund N, Thompson BS, Meda S, Andersen SL (2016) Preventative treatment in an animal model of ADHD: Behavioral and biochemical effects of methylphenidate and its interactions with ovarian hormones in female rats. Eur Neuropsychopharmacol 26 (9):1496-1506. doi:10.1016/j.euroneuro.2016.06.003

Mason ST, Fibiger HC (1979) Neurochemical basis of the dorsal bundle extinction effect. Pharmacol Biochem Behav 10 (3):373-380

Monterosso JR, Aron AR, Cordova X, Xu J, London ED (2005) Deficits in response inhibition associated with chronic methamphetamine abuse. Drug Alcohol Depend 79 (2):273-277. doi:10.1016/j.drugalcdep.2005.02.002

Nigg JT, Blaskey LG, Stawicki JA, Sachek J (2004) Evaluating the endophenotype model of ADHD neuropsychological deficit: results for parents and siblings of children with ADHD combined 
and inattentive subtypes. J Abnorm Psychol 113 (4):614-625. doi:10.1037/0021843x.113.4.614

Nishi A, Kuroiwa M, Miller DB, O'Callaghan JP, Bateup HS, Shuto T, Sotogaku N, Fukuda T, Heintz N, Greengard P, Snyder GL (2008) Distinct roles of PDE4 and PDE10A in the regulation of CAMP/PKA signaling in the striatum. J Neurosci 28 (42):10460-10471. doi:10.1523/jneurosci.2518-08.2008

Nishi A, Kuroiwa M, Shuto $T$ (2011) Mechanisms for the modulation of dopamine $d(1)$ receptor signaling in striatal neurons. Front Neuroanat 5:43. doi:10.3389/fnana.2011.00043

Nishi A, Shuto T (2017) Potential for targeting dopamine/DARPP-32 signaling in neuropsychiatric and neurodegenerative disorders. Expert Opin Ther Targets:1-14. doi:10.1080/14728222.2017.1279149

Nishi A, Snyder GL (2010) Advanced research on dopamine signaling to develop drugs for the treatment of mental disorders: biochemical and behavioral profiles of phosphodiesterase inhibition in dopaminergic neurotransmission. J Pharmacol Sci 114 (1):6-16

Oosterlaan J, Logan GD, Sergeant JA (1998) Response inhibition in AD/HD, CD, comorbid AD/HD + CD, anxious, and control children: a meta-analysis of studies with the stop task. J Child Psychol Psychiatry 39 (3):411-425

Paxinos G, Watson C, Carrive P, Kirkcaldie M, Ashwell K (2009) Chemoarchitectonic atlas of the rat brain.

Penadés R, Catalán R, Rubia K, Andrés S, Salamero M, Gastó C (2007) Impaired response inhibition in obsessive compulsive disorder. Eur Psychiatry 22 (6):404-410. doi:http://dx.doi.org/10.1016/j.eurpsy.2006.05.001

Richter W, Menniti FS, Zhang HT, Conti M (2013) PDE4 as a target for cognition enhancement. Expert Opin Ther Targets 17 (9):1011-1027. doi:10.1517/14728222.2013.818656

Rubia K, Oosterlaan J, Sergeant JA, Brandeis D, v Leeuwen T (1998) Inhibitory dysfunction in hyperactive boys. Behav Brain Res 94 (1):25-32

Rubia K, Smith A, Taylor E (2007) Performance of children with attention deficit hyperactivity disorder (ADHD) on a test battery of impulsiveness. Child Neuropsychol 13 (3):276-304. doi:10.1080/09297040600770761

Rubia K, Smith AB, Brammer MJ, Toone B, Taylor E (2005) Abnormal brain activation during inhibition and error detection in medication-naive adolescents with ADHD. Am J Psychiatry 162 (6):1067-1075. doi:10.1176/appi.ajp.162.6.1067

Schachar R, Logan GD, Robaey P, Chen S, Ickowicz A, Barr C (2007) Restraint and cancellation: multiple inhibition deficits in attention deficit hyperactivity disorder. J Abnorm Child Psychol 35 (2):229-238. doi:10.1007/s10802-006-9075-2

Schachar R, Tannock R, Marriott M, Logan G (1995) Deficient inhibitory control in attention deficit hyperactivity disorder. J Abnorm Child Psychol 23 (4):411-437

Schoffelmeer AN, Wardeh G, Mulder AH (1985) Cyclic AMP facilitates the electrically evoked release of radiolabelled noradrenaline, dopamine and 5-hydroxytryptamine from rat brain slices. Naunyn Schmiedebergs Arch Pharmacol 330 (1):74-76

Seino S, Shibasaki T (2005) PKA-dependent and PKA-independent pathways for cAMP-regulated exocytosis. Physiol Rev 85 (4):1303-1342. doi:10.1152/physrev.00001.2005

Surmeier DJ, Carrillo-Reid L, Bargas J (2011) Dopaminergic modulation of striatal neurons, circuits, and assemblies. Neuroscience 198:3-18. doi:10.1016/j.neuroscience.2011.08.051

Surmeier DJ, Ding J, Day M, Wang Z, Shen W (2007) D1 and D2 dopamine-receptor modulation of striatal glutamatergic signaling in striatal medium spiny neurons. Trends Neurosci 30 (5):228235. doi:10.1016/j.tins.2007.03.008

Suzuki K, Harada A, Shiraishi E, Kimura H (2015) In vivo pharmacological characterization of TAK-063, a potent and selective phosphodiesterase $10 \mathrm{~A}$ inhibitor with antipsychotic-like activity in rodents. J Pharmacol Exp Ther 352 (3):471-479. doi:10.1124/jpet.114.218552

van den Wildenberg WP, van Boxtel GJ, van der Molen MW, Bosch DA, Speelman JD, Brunia $\mathrm{CH}$ (2006) Stimulation of the subthalamic region facilitates the selection and inhibition of motor responses in Parkinson's disease. J Cogn Neurosci 18 (4):626-636. doi:10.1162/jocn.2006.18.4.626

van Gaalen MM, Brueggeman RJ, Bronius PF, Schoffelmeer AN, Vanderschuren L (2006) Behavioral disinhibition requires dopamine receptor activation. Psychopharmacology (Berl) 187 (1):7385. doi:10.1007/s00213-006-0396-1 
Vanmierlo T, Creemers P, Akkerman S, van Duinen M, Sambeth A, De Vry J, Uz T, Blokland A, Prickaerts J (2016) The PDE4 inhibitor roflumilast improves memory in rodents at non-emetic doses. Behav Brain Res 303:26-33. doi:10.1016/j.bbr.2016.01.031

Winstanley CA (2011) The utility of rat models of impulsivity in developing pharmacotherapies for impulse control disorders. $\mathrm{Br} J$ Pharmacol 164 (4):1301-1321. doi:10.1111/j.14765381.2011.01323.x

Winstanley CA, Eagle DM, Robbins TW (2006) Behavioral models of impulsivity in relation to ADHD: translation between clinical and preclinical studies. Clin Psychol Rev 26 (4):379-395. doi:10.1016/j.cpr.2006.01.001

Zhu G, Okada M, Yoshida S, Hirose S, Kaneko S (2004) Pharmacological discrimination of protein kinase associated exocytosis mechanisms between dopamine and 3,4dihydroxyphenylalanine in rat striatum using in vivo microdialysis. Neurosci Lett 363 (2):120124. doi:10.1016/j.neulet.2004.03.054 
Chapter 7

General Discussion 


\section{Aim of the dissertation}

The main aim of the current dissertation was to investigate the function of PDE4 in cognitive frontostriatal circuits. The focus was set on cognition, opposed to motor and limbic functions of the frontostriatal circuits, and included cognitive functions such as attention, sensory gating, sensorimotor gating and impulsivity. After providing a critical review of the current status in the field we continued in twofold. On the one hand, we aimed to investigate the effects of PDE4 inhibition by means of roflumilast on behavioral outcomes in an auditory sensory gating paradigm (Chapter 4) as well as in a paradigm related to motor impulsivity (Chapter 6). On the other hand, we aimed to examine the functional output of the fronto-striatal circuit to the thalamus using an electrophysiological approach (Chapter 5). Also, we aimed to test both physiological (Chapter 4 and Chapter 5) as well as the pathophysiological (Chapter 6) conditions of the fronto-striatal circuit.

\section{Overview main findings of the dissertation}

PDEs appear to be a promising target in the field of cognition enhancement related to fronto-striatal functioning. Although this relatively new field in PDE research is just emerging, clear positive effects have already been found in animals and we are now awaiting translational confirmation by human data. As such, attention, sensory gating, sensorimotor gating and impulsivity are emerging cognitive domains in the field of PDE research. In Chapter 2 we discussed experimental studies and the potential beneficial effects of PDE inhibitors in these cognitive domains. Overall, PDE4 seems to be the most promising target for the four domains discussed in the chapter. Chapter 3 continues providing an overview of the current knowledge on the role of PDE1, PDE4 and PDE10 in the regulation of dopaminergic modulation of fronto-striatal circuits. The interplay between PDEs and dopamine in relation to the cognitive functions is discussed in more detail. In addition to a discussion on the neurobiological mechanisms of PDE inhibition, a clinical perspective is provided.

In Chapter 4 we investigated whether the PDE4 inhibitor roflumilast could enhance sensory gating in healthy young human volunteers. We aimed to find effects purely on gating without exhibiting an effect on overall auditory processing as indicated by auditory evoked potentials (AEP) to assure that PDE4 inhibition affects pure gating. Results showed that roflumilast significantly improved sensory gating in our participants. This effect was induced in a dose-dependent manner. No emetic side effects were reported by the participants after administration of the effective low dose. This means roflumilast shows a beneficial effect on gating at a dose that had no adverse effects reported following single-dose administration in the present study. 
Studies discussed in chapter 5 were conducted to address the functional output of the fronto-striatal circuit to the thalamus at an electrophysiological level using rats. This was accomplished by studying the distinctive effects of PDE4 inhibition on the three basal ganglia pathways: the hyperdirect, direct and indirect pathway. This was done by examining the effects on the tri-phasic (excitation-inhibitionexcitation) response of the $\mathrm{SNr}$ after infralimbic cortex stimulation. The tri-phasic response of the $\mathrm{SNr}$ represents activation of the hyper direct, direct and indirect basal ganglia pathways. Our results provide support for the hypothesis that, under normal conditions, PDE4 inhibition affects the direct and mainly the indirect pathways of the basal ganglia, but not the hyperdirect pathway.

In Chapter 6, the mediating role of PDE4 in the dopaminergic modulation of premature responding (motor impulsivity) was investigated in rats. We tested the effects of roflumilast on premature responding in the choice serial reaction time task (CSRTT) in a hypo, normal and hyper dopaminergic state of the cognitive fronto-striatal circuit. In line with the notion of a U-shaped relation between dopamine and impulsive responding, we found that both increasing and decreasing dopamine levels (by systemic d-amphetamine administration or a medial prefrontal 6-OHDA lesion, respectively) resulted in an increase in premature responding in the CSRTT. Treating the 6-OHDA lesioned animals with roflumilast restored the level of premature responding back to the level of the sham-lesioned animals. Additionally, in line with our hypothesis roflumilast further increased the already heightened level of premature responding in the hyper dopaminergic state of the fronto-striatal circuit, induced by d-amphetamine.

\section{Main implication of the dissertation}

The main aim of the current dissertation was to investigate whether PDE4 could be a relevant target for the treatment of cognitive dysfunctions in disorders related to the fronto-striatal circuits (Nishi and Shuto 2017; Nishi et al. 2011; Nishi et al. 2008). Besides cognitive behavioral therapy, there is hardly any efficacious pharmacological treatment without major side effects for these disorders, including attention deficit hyper activity disorder (ADHD), schizophrenia and Parkinson's disease. The focus was set on cognition and the role of dopamine (Gerfen and Surmeier 2011; Gerfen et al. 1990). As a result, we tried to regulate dopaminergic modulation of the fronto-striatal circuits via PDE4 inhibition examining the effects in several cognitive domains like sensory gating and impulsivity. Currently available dopaminergic treatments, like methylphenidate, are very nonspecific and induce many side effects (e.g., cardiac abnormalities, addiction, growth inhibition) resulting in lowcompliance and high relapse rates in patients. Therefore, there is a clear need for more basic 
knowledge regarding the role of dopamine in the physiology of the fronto-striatal circuits to generate new targets; and a clear need for the proper development of treatments for related diseases.

\section{Roflumilast and the tri-phasic response}

To increase our basic understanding of the role of PDE4 in the three basal ganglia pathways of the fronto-striatal circuits, we turned to in vivo electrophysiology due to its high spatial and temporal resolution. The first step encompasses the verification of the tri-phasic response in the cognitive fronto-striatal circuits, the same way it is observed in the motor circuits. An important difference between the rat brain and the human brain in this respect, involves the fact that cognitive areas in the prefrontal cortex project to the nucleus accumbens and leave the basal ganglia mainly via the ventral pallidum with less projections to the substantia nigra pars reticulata (SNr)(Groenewegen et al. 1999; Deniau et al. 1994; Maurice et al. 1999). In the current dissertation we showed that a tri-phasic response resembling the three basal ganglia pathways can be induced via infralimbic cortex stimulation.

Subsequently, we checked for effects of roflumilast on any of the three phases separately. Previous studies using immunohistochemistry provided us with an indication regarding expression of PDE4 in the three basal ganglia pathways (Nishi et al. 2011; Nishi et al. 2008; Nishi and Snyder 2010). However, the effects on the functional output of the pathways to the SNr remained to be elucidated. Our study showed for the first time the effects of roflumilast on the output of the three pathways. In line with the previous immunohistochemical data, we observed that roflumilast modulated output of the direct and indirect pathways but not of the hyperdirect pathway. The most potent effect was observed for the indirect pathway. In contrast to what was expected based on the immunohistochemical data, we observed an increase in action potentials from the direct pathway (indicative of reduced activation of the direct pathway). Likewise, we observed a reduction in action potentials coming from the indirect pathway (indicative of reduced activation of the indirect pathway). The absence of effects in the hyperdirect pathway indicates that the effects in the other two pathways may have originated in the striatum or globus pallidus pars externa (GPe). The indirect pathway shares its ending namely with the hyperdirect pathway, which remained unaffected. The exact intracellular compartmentalized signaling pathways responsible for the current findings remain to be elucidated in our future studies. We can, however, hypothesize in light of the current findings, that roflumilast is likely an interesting treatment for disorders benefiting from reduced indirect pathway activation like ADHD. 
Our unique from "bench to bed and back again" approach in this dissertation also resulted in the triphasic response likely being able to be used as a biomarker (i.e. as electroencephalogram (EEG) and event-related potential (ERP) correlate). This further opens up possibilities for a translational approach as the tri-phasic response can be used as a translational electrophysiological measure. The rationale behind the tri-phasic response was inferred from patients exhibiting basal ganglia-related symptoms, subsequently tested in animals to result in an electrophysiological correlate known as "tri-phasic response of the SNr", which, now that is has been validated, might be used for patient diagnosis and prognosis.

\section{Roflumilast and sensory gating}

Next to increasing our basic knowledge regarding the role of dopamine in the physiology of the fronto-striatal circuits, we investigated the potential of PDE4 inhibitors as efficacious treatment for impaired (dopaminergic) cognitive function related to fronto-striatal circuits. We investigated both physiological and pathophysiological conditions. In line with the translational approach we aspired, both rodents and humans were tested. Cognitive domains related to the fronto-striatal circuits investigated in the current dissertation include sensory gating and motor impulse control.

The effects of roflumilast on sensory gating were investigated in healthy human volunteers. Sensory gating is a process that prevents overstimulation of the brain and is measured by deriving ERPs from the EEG. Roflumilast $100 \mu \mathrm{g}$ improved sensory gating at the P50 peak of the Fz electrode indicating improved frontal gating. Impairments in gating are characteristic of disorders like schizophrenia, ADHD and Alzheimer's disease. As a result it would be interesting to continue future studies by testing the efficacy of roflumilast in a sensory gating paradigm in either a deficit model or in patients. The d-amphetamine deficit model is likely the most suitable deficit model as it mimics impaired D2 signaling in schizophrenia. Other options include phencyclidine (PCP) or biperiden depending on the neuropsychiatric disorder under investigation.

The classic PDE4 inhibitor rolipram has already shown to improve sensory gating in the $d$ amphetamine deficit model (Halene and Siegel 2008; Maxwell et al. 2004). However, this might only be indicative of antipsychotic potential of the drug. Anti-psychotic potential is defined here as the ability to reverse D2 indirect pathway hyperactivity. The biological mechanism behind improved gating in the frontal cortex is most likely explained via stimulation of $\gamma$-aminobutyric acid (GABA)ergic interneurons, not via the D2 pathway. These interneurons terminate the response to the first stimulus via $G A B A_{A}$ receptors and diminish to response to the second stimulus via activation of $G_{A B A_{B}}$ receptors (Smucny et al. 2015). Future studies will have to further elucidate the 
compartmentalized role of PDE4 in intracellular signaling cascades within these inhibitory interneurons. Notably, PDE4 inhibition might thus not only benefit ADHD patients via decreased basal ganglia indirect pathway activation (as shown with the tri-phasic response) but also via frontal mechanisms.

\section{Roflumilast and motor impulse control}

Another cognitive domain investigated in the current dissertation is motor impulsivity. Current knowledge on the human neuroanatomical substrate of impulse control points to the fronto-striatal circuits (Alexander et al. 1986; Dalley et al. 2011; Chudasama and Robbins 2006). To investigate the role of dopamine in premature responding in the CSRTT we induced a hypo, normal and hyper dopaminergic state of the cognitive fronto-striatal circuit. Interestingly, results followed the Ushaped dose-response curve confirming our hypothesis that both low and high levels of dopamine induce motor impulsivity. PDE4 inhibition is known to induce several effects in the fronto-striatal circuits (Nishi et al. 2008). It affects both the direct and indirect pathway (with a more potent effect in the latter, as observed during our electrophysiological recordings) and the dopaminergic terminals in striatum and frontal cortex (Nishi and Snyder 2010). Effects at the dopaminergic terminals include increased release of dopamine (e.g. Schoffelmeer et al. 1985; Nishi and Snyder 2010). The shift to the right on the dose response curve after roflumilast treatment, depicted in Figure 1 of chapter 6, showing the relation between dopamine and impulse control, is in line with the assumption that PDe4 inhibition induces dopamine release.

ADHD patients are characterized by frontal hypodopaminergia (Arnsten 2009). By increasing their frontal dopamine levels via PDE4 inhibition, that is to say shifting dopamine levels to the right on the dose response curve (towards optimal levels); a PDE4 inhibitor potentially replaces the loss in cAMP signaling due to a loss in presynaptic dopamine. A similar mechanism (dopamine agonism of the postsynaptic receptor) applies to psychostimulants like methylphenidate, currently used to treat ADHD. However, PDE4 inhibitors including roflumilast have none of the severe side effects observed after psychostimulant treatment. Especially, if we combine the current findings on premature responding with findings from both other chapters, a PDE4 inhibitor seems a very promising treatment for ADHD. It improves several cognitive functions whose impairments are hallmarks of ADHD, such as motor impulse control and sensory gating. By decreasing direct pathway activation it can be hypothesized that roflumilast will also decrease hyperactivity. In fact, studies with the PDE4 inhibitor rolipram have shown a decrease of spontaneous and drug-induced (hyper)locomotion (Siuciak et al. 2007). The third major hallmark of ADHD is an attention deficit. Not much research has been conducted in the field of attention and PDE inhibition. However, two studies have shown that 
rolipram reversed a MK-801-, bupropion-, amphetamine-, and GBR12783-induced latent inhibition deficit indicative of improved attentional performance (Davis and Gould 2005; Lipina and Roder 2009). A potential role for PDE4 inhibition in hyperactivity and attention remains to be further elucidated in future studies.

Of note, in the present dissertation we only investigated motor impulsivity (action restraint). However, the motor domain (impulsive action) also includes response inhibition. The latter is usually measured by means of the Stop-Signal Task, both in humans and rodents (Winstanley 2011). Additionally, there are two other major cognitive domains within the taxonomy of impulsivity next to impulsive action, i.e. impulsive choice (decision making $\rightarrow$ delay-, probability-, and effort-based discounting) and reflection impulsivity. Studies in both rodents and humans have shown that current ADHD psychostimulant treatment has opposite effects on impulsive action and impulsive choice. How this relates to PDE4 inhibition should also be further investigated in future studies.

As mentioned in the discussion chapter of the current dissertation, we focused on the cognitive fronto-striatal circuits. However, next to the cognitive circuits, the total fronto-striatal circuitry entails also motor and limbic circuits. These circuits are characterized by the same three basal ganglia pathways (hyperdirect, direct and indirect) including their modulation by dopamine. Hypothesizing, if we would apply the same hypo and hyper dopaminergic states to the motor circuits as we did to the cognitive circuits, it would result in hypokinetic movement disorders (like Parkinson's disease) and hyperkinetic movement disorders (like Huntington's disease), respectively. In the same way PDE4 inhibition can benefit ADHD, it might also benefit Parkinson's disease patients or any other movement disorder characterized by striatal hypodopaminergia. PDE4 inhibitors would target the same intracellular signaling pathways normally activated by dopamine, providing a substitute for the loss in dopamine due to neurodegeneration. More in detail, neurodegeneration of the presynaptic dopaminergic neurons results in dopaminergic treatments (e.g. levodopa) becoming ineffective over time. PDE4 inhibitors target the postsynaptic neuron enhancing signaling pathways usually activated by dopamine.

Along the same line of reasoning, it can be hypothesized that disorders with frontal hypodopaminergia benefit from PDE4 inhibition. Like the cognitive symptoms in ADHD, cognitive symptoms in, for instance, schizophrenia could be reduced via PDE4 inhibition. Cognitive symptoms in schizophrenia are believed to result from decreased dopamine D1 receptor signaling in the frontal cortex (Green 1996). D1 receptors activate the cAMP signaling cascade which is also stimulated by the inhibition of PDE4 (Kuroiwa et al. 2012). In fact, a clinical trial conducted at King's College London 
showed positive results on cognitive function in schizophrenia patients after antipsychotic medication combined with roflumilast compared to antipsychotic medication alone (ClinicalTrials.gov Identifier: NCT02079844). Taken together, results of the current dissertation could potentially benefit several disorders related to impaired dopaminergic functioning of the fronto-striatal circuits.

\section{General conclusion}

Dopamine plays an essential role in the physiology of fronto-striatal circuits. The intracellular cascades involved in dopamine signaling involve cyclic nucleotide PDEs with an emphasis on PDE4. PDE4 inhibitors target dopaminergic signaling cascades in the frontal cortex and basal ganglia pathways, and induce the release of dopamine therein. Therefore, PDE4 seems to be a promising target regarding treatment for disorders affected by understimulated dopaminergic signaling in fronto-striatal circuits. In the current dissertation, we have increased our knowledge regarding the functional role of PDE4 in the dopaminergic modulation of fronto-striatal circuits. Results obtained in the dissertation provide us with enough data to expand the current research line. 


\section{References}

Alexander GE, DeLong MR, Strick PL (1986) Parallel organization of functionally segregated circuits linking basal ganglia and cortex. Annu Rev Neurosci 9 (1):357-381

Arnsten AF (2009) Toward a new understanding of attention-deficit hyperactivity disorder pathophysiology: an important role for prefrontal cortex dysfunction. CNS Drugs 23 Suppl 1:33-41. doi:10.2165/00023210-200923000-00005

Chudasama Y, Robbins TW (2006) Functions of frontostriatal systems in cognition: comparative neuropsychopharmacological studies in rats, monkeys and humans. Biol Psychol 73 (1):19-38. doi:10.1016/j.biopsycho.2006.01.005

Dalley JW, Everitt BJ, Robbins TW (2011) Impulsivity, compulsivity, and top-down cognitive control. Neuron 69 (4):680-694. doi:10.1016/j.neuron.2011.01.020

Davis JA, Gould TJ (2005) Rolipram Attenuates MK-801-Induced Deficits in Latent Inhibition. Behav Neurosci 119 (2):595-602. doi:10.1037/0735-7044.119.2.595

Deniau JM, Menetrey A, Thierry AM (1994) Indirect nucleus accumbens input to the prefrontal cortex via the substantia nigra pars reticulata: a combined anatomical and electrophysiological study in the rat. Neuroscience 61 (3):533-545

Gerfen CR, Engber TM, Mahan LC, Susel Z, Chase TN, Monsma FJ, Jr., Sibley DR (1990) D1 and D2 dopamine receptor-regulated gene expression of striatonigral and striatopallidal neurons. Science 250 (4986):1429-1432

Gerfen CR, Surmeier DJ (2011) Modulation of striatal projection systems by dopamine. Annu Rev Neurosci 34:441-466. doi:10.1146/annurev-neuro-061010-113641

Green MF (1996) What are the functional consequences of neurocognitive deficits in schizophrenia? Am J Psychiatry 153 (3):321-330. doi:10.1176/ajp.153.3.321

Groenewegen HJ, Galis-de Graaf Y, Smeets WJ (1999) Integration and segregation of limbic corticostriatal loops at the thalamic level: an experimental tracing study in rats. J Chem Neuroanat $16(3): 167-185$

Halene TB, Siegel SJ (2008) Antipsychotic-like properties of phosphodiesterase 4 inhibitors: evaluation of 4-(3-butoxy-4-methoxybenzyl)-2-imidazolidinone (RO-20-1724) with auditory event-related potentials and prepulse inhibition of startle. J Pharmacol Exp Ther 326 (1):230239. doi:10.1124/jpet.108.138586

Kuroiwa M, Snyder GL, Shuto T, Fukuda A, Yanagawa Y, Benavides DR, Nairn AC, Bibb JA, Greengard $P$, Nishi A (2012) Phosphodiesterase 4 inhibition enhances the dopamine D1 receptor/PKA/DARPP-32 signaling cascade in frontal cortex. Psychopharmacology (Berl) 219 (4):1065-1079. doi:10.1007/s00213-011-2436-8

Lipina T, Roder J (2009) A new model of the disrupted latent inhibition in C57BL/6J mice after bupropion treatment. Psychopharmacology (Berl) 208 (3):487-498. doi:10.1007/s00213-0091749-3

Maurice N, Deniau JM, Glowinski J, Thierry AM (1999) Relationships between the prefrontal cortex and the basal ganglia in the rat: physiology of the cortico-nigral circuits. J Neurosci 19 (11):4674-4681

Maxwell CR, Kanes SJ, Abel T, Siegel SJ (2004) Phosphodiesterase inhibitors: a novel mechanism for receptor-independent antipsychotic medications. Neuroscience 129 (1):101-107. doi:10.1016/j.neuroscience.2004.07.038

Nishi A, Kuroiwa M, Miller DB, O'Callaghan JP, Bateup HS, Shuto T, Sotogaku N, Fukuda T, Heintz N, Greengard P, Snyder GL (2008) Distinct roles of PDE4 and PDE10A in the regulation of cAMP/PKA signaling in the striatum. J Neurosci 28 (42):10460-10471. doi:10.1523/jneurosci.2518-08.2008

Nishi A, Kuroiwa M, Shuto T (2011) Mechanisms for the modulation of dopamine $d(1)$ receptor signaling in striatal neurons. Front Neuroanat 5:43. doi:10.3389/fnana.2011.00043 
Nishi A, Shuto T (2017) Potential for targeting dopamine/DARPP-32 signaling in neuropsychiatric and neurodegenerative disorders. Expert Opin Ther Targets:1-14. doi:10.1080/14728222.2017.1279149

Nishi A, Snyder GL (2010) Advanced research on dopamine signaling to develop drugs for the treatment of mental disorders: biochemical and behavioral profiles of phosphodiesterase inhibition in dopaminergic neurotransmission. J Pharmacol Sci 114 (1):6-16

Schoffelmeer AN, Wardeh G, Mulder AH (1985) Cyclic AMP facilitates the electrically evoked release of radiolabelled noradrenaline, dopamine and 5-hydroxytryptamine from rat brain slices. Naunyn Schmiedebergs Arch Pharmacol 330 (1):74-76

Siuciak JA, Chapin DS, McCarthy SA, Martin AN (2007) Antipsychotic profile of rolipram: efficacy in rats and reduced sensitivity in mice deficient in the phosphodiesterase-4B (PDE4B) enzyme. Psychopharmacology (Berl) 192 (3):415-424. doi:10.1007/s00213-007-0727-x

Smucny J, Stevens KE, Olincy A, Tregellas JR (2015) Translational utility of rodent hippocampal auditory gating in schizophrenia research: a review and evaluation. Translational psychiatry 5:e587. doi:10.1038/tp.2015.77

Winstanley CA (2011) The utility of rat models of impulsivity in developing pharmacotherapies for impulse control disorders. $\mathrm{Br} J$ Pharmacol 164 (4):1301-1321. doi:10.1111/j.14765381.2011.01323.x 
Chapter 8

Summary 
The aim of the current PhD dissertation was to target phosphodiesterase type 4 for improving cognitive fronto-striatal functioning via a translational approach. The general introduction (Chapter 1) described the rationale of this dissertation and the aims of the studies discussed herein.

Chapter 2: PDE inhibitors enhance CAMP and/or CGMP signaling via reducing the degradation of these cyclic nucleotides. Both CAMP and cGMP signaling are essential for a variety of cellular functions and exert their effects both pre- and post-synaptically. Either of these second messengers relays and amplifies incoming signals at receptors on the cell surface making them important elements in signal transduction cascades and essential in cellular signaling in a variety of cell functions including neurotransmitter release and neuroprotection. Consequently, these processes can be influenced by PDE inhibitors as they increase CAMP and/or CGMP concentrations. PDE inhibitors have been considered as possible therapeutic agents to treat impaired cognitive function linked to fronto-striatal circuits, including ADHD, schizophrenia and Parkinson's disease. In Chapter 2 we discussed the involvement of PDEs on four related domains: attention, information filtering (sensory- and sensorimotor gating) and response inhibition. Currently, these are emerging cognitive domains in the field of PDE research. We discussed experimental studies and the potential beneficial effects of PDE inhibitors on these cognitive domains. Overall, PDE4 seems to be the most promising target for all domains discussed in the chapter.

Chapter 3: Chapter 3 provides a detailed discussion of the relation between PDEs and dopamine in relation to the cognitive functions. Subsequently, an overview is provided of the current clinical status. Clinical trials investigating the effects of PDE inhibitors in neuropsychiatric disorders are overall very sparse and the wealth of positive preclinical data could not yet be translated into clinical efficacy.

Chapter 4: Research has shown that the process of sensory gating is disrupted in patients suffering from clinical disorders including ADHD, schizophrenia and Alzheimer's disease. PDE inhibitors have received an increased interest as a tool to improve cognitive performance related to fronto-striatal functioning in both animals and man. One of the cognitive areas investigated is sensory gating. Therefore, we investigated the effects of the PDE4 inhibitor roflumilast in a sensory gating paradigm in 20 healthy young human volunteers (age range $18-30$ years). We applied a placebo-controlled randomized cross-over design and tested 3 doses $(100,300,1000 \mu \mathrm{g})$. Results discussed in this chapter showed that roflumilast improved sensory gating in healthy young human volunteers only at the $100 \mu \mathrm{g}$ dose. This means roflumilast shows a beneficial effect on gating at a dose that had no adverse effects reported following single-dose administration. This indicates that roflumilast $100 \mu \mathrm{g}$ 
has a favorable side-effect profile. Roflumilast and PDE4 inhibition in general could therefore be seen as a promising treatment in disorders affected by disrupted sensory gating.

Chapter 5: In Chapter 5 we examined the functional output of the fronto-striatal circuit to the thalamus at an electrophysiological level by studying the distinctive effects of PDE4 inhibition on the three basal ganglia pathways: the hyperdirect, direct and indirect pathway. Effects of roflumilast on the three pathways were studied via the tri-phasic (excitation-inhibition-excitation) response of the SNr after infralimbic cortex stimulation. Results show for the first time that stimulation of the infralimbic cortex leads to a tri-phasic response in the SNr, topographically and functionally associated with the cognitive parts of the basal ganglia. Interestingly, we found that PDE4 inhibition resulted in inhibition of the direct pathway and reduced activation of the indirect pathway at the level of the SNr. This finding is likely due to the complexity of the system already at hand at the level of the SNr, i.e. the abundant number of feedback and feedforward connections within the circuits as well as their mediation and modulation by PDE4 and several neurotransmitter systems. Most importantly, in line with previous studies, PDE4 inhibition by roflumilast affects both the direct pathway as well as the indirect pathway of which the latter appears more affected than the former.

Chapter 6: In Chapter 6, the mediating role of PDE4 in the dopaminergic modulation of premature responding (motor impulsivity) was studied. We investigated the effects of roflumilast on premature responding in the choice serial reaction time task (CSRTT) in a hypo, normal and hyper dopaminergic state of the cognitive fronto-striatal circuit. Results showed that both increasing and decreasing dopamine levels resulted in an increase in premature responding in the CSRTT. Results indicated a role for PDE4 inhibitors in shifting performance on premature responding to the right on the Ushaped dose response curve. As a result, it would be interesting to test the effects of PDE4 inhibition in disorders affected by disrupted impulse control related to fronto-striatal hypodopaminergia including ADHD. 
Appendices

Valorization addendum

About the author

List of publications

Acknowledgements 
Valorization addendum 


\section{Relevance for society and Target groups}

The dopaminergic fronto-striatal circuits constitute the neurobiological basis of several neuropsychiatric disorders, including neurodegenerative disorders like Parkinson's disease and Huntington's disease, psychiatric illnesses such as schizophrenia and obsessive-compulsive disorder $(O C D)$, and pervasive developmental disorders like attention deficit hyperactivity disorder (ADHD) and autism spectrum disorder (Alexander et al. 1986; Haber and Rauch 2010; Gunaydin and Kreitzer 2015). Dysfunction of these circuits produces the wide range of motor, cognitive and affective symptoms observed in related neuropsychiatric disorders (Chudasama and Robbins 2006).

The burden that cognitive impairments impose on the quality of life is enormous. Not only for those who suffer from it but also for their families and caregivers. For instance, as many as one million Americans live with Parkinson's disease, which is more than the combined number of people diagnosed with multiple sclerosis, muscular dystrophy and Lou Gehrig's disease. Approximately 60,000 Americans are diagnosed with Parkinson's disease each year, and this number does not reflect the thousands of cases that go undetected. More than 10 million people worldwide are living with Parkinson's disease. Incidence of Parkinson's increases with age, but an estimated four percent of people with Parkinson's disease are diagnosed before the age of 50 .

Schizophrenia is another devastating disorder of the fronto-striatal circuits for most people who are afflicted, and very costly for families and society. The overall U.S. 2002 cost of schizophrenia was estimated to be $\$ 62.7$ billion, with $\$ 22.7$ billion excess direct health care cost $(\$ 7.0$ billion outpatient, $\$ 5.0$ billion drugs, $\$ 2.8$ billion inpatient, $\$ 8.0$ billion long-term care). The Prevalence Rate for schizophrenia is approximately $1.1 \%$ of the population over the age of 18 or, in other words, at any one time as many as 51 million people worldwide suffer from schizophrenia, including 2.2 million people in the United States (US), 285,000 people in Australia, over 280,000 people in Canada and over 250,000 diagnosed cases in the United Kingdom (UK).

5.1 million Children in the US ( $8.8 \%$ or 1 in 11 of the age group $4-17$ years) have a current diagnosis of ADHD: $6.8 \%$ of children ages $4-10$ ( 1 in 15 ); $11.4 \%$ of children ages $11-14$ ( 1 in 9 ); $10.2 \%$ of children ages 15-17 ( 1 in 10). Additionally, 6.4 million children (11\% of the age group $4-17$ years) have ever been diagnosed with ADHD, and rates of ever-diagnosed ADHD increased an average of approximately 5\% per year from 2003 to 2011 . Estimated cost to US society entails $\$ 42.5$ billion dollar annually. 
Without going into the statistics of the other disorders, it becomes clear from the numbers provided for the three examples above, that the need to increase our understanding of the physiology and pathophysiology of the fronto-striatal circuits is of utmost importance. Increasing our understanding of fronto-striatal circuits' biology will not only aid in better understanding the many different disorders related to the circuits, but it will also create new targets for pharmacological treatment and generate possible biomarkers as is further explained below.

Besides cognitive behavioral therapy, there is currently hardly any pharmacological treatment for disorders related to dysfunctional fronto-striatal circuits. Presently available dopaminergic treatments for ADHD, Parkinson's disease and schizophrenia are very nonspecific and induce many side effects (cardiac arrhythmias, addiction, growth inhibition, dyskinesias, dopamine dysregulation syndrome, etc.). This results in low-compliance and high relapse rates, again stressing the need for more basic knowledge regarding the role of dopamine in the physiology of the fronto-striatal circuits and the possible impact of the current dissertation. By modulating the same intracellular machinery via phosphodiesterase type 4 (PDE4) inhibitors as would dopamine itself via the extracellular receptor, we tried to regulate the dopaminergic modulation of the fronto-striatal circuitry. Thereby, we reverse the decrease in intracellular signaling due to the loss in dopamine. Main benefit of PDE4 inhibitors compared to dopaminergic medication includes increased efficacy and improved sideeffect profile. From the results of the current dissertation it seems that especially disorders characterized by hypodopaminergia, including ADHD and Parkinson's disease, will benefit from PDE4 inhibition.

Cognitive symptoms observed in ADHD, including sensory gating and attention deficits, as well as impulsivity and hyperactivity seem to be beneficially affected by PDE4 inhibition. Roflumilast is currently the only clinically approved PDE4 inhibitor available for oral administration with a unique side effect profile compared to both, for PDE4 inhibitors typically observed, emetic effects and psychostimulant-induced side effects.

\section{Effectiveness and feasibility for use of knowledge to meet the needs of others}

Through publications and presentations at conferences I will inform the scientific community in the field of our results and outcomes of translational research. In the case of positive results, I will also explore the possibilities of patenting new treatments of ADHD based on the newly generated targets using our Technology Transfer Office. On the one hand for monotherapy but also for combination therapy with existing dopaminergic drugs (e.g. Ritalin) to reduce their side effects. This would greatly help my research to bring in extra funding. Further, I will contact relevant patient organizations (like 
the foundation Attention Deficit Disorders (ADD)) as well as the Trimbos. Patient organizations would like to learn more about the latest treatment options and the Trimbos focuses on improving health care through sharing knowledge. This way, we will also reach health care professionals to share our knowledge and possibly recruit volunteers for future studies.

\section{Activity/Products and Innovation}

Our unique from "bench to bed and back again" approach has the potential to result in the generation of new targets to develop improved treatments for patients with ADHD. PDE4 seems to be a very promising target based on results of the current dissertation. Next to the generation of new treatments, the current project also has the potential to generate new biomarkers including electroencephalogram (EEG) and event-related potential (ERP) correlates. The latter will lead to better and faster diagnosis improving prognosis. Improved prognosis will lead to reduced cost for society and increased quality of life for patients and family.

Additionally, results of the current dissertation further add to the evidence that cognitive projections, or at least those originating in the infralimbic cortex, can induce a tri-phasic response in the SNr. As a result, it also implies the existence of a division within the basal ganglia into a hyper, direct and indirect pathway, in the cognitive fronto-striatal circuit originating in the infralimbic cortex. Thus, this also confirms the hypothesis of the existence of the three pathways in the cognitive fronto-striatal circuits as they do in the motor circuits (e.g. Maurice et al. 1999; Beyeler et al. 2010).

Finally, we have implemented and verified a new model for motor impulsivity as seen in ADHD. Currently, there is no good model for ADHD available in animals except for the Spontaneously Hypertensive Rat. This model shows high face validity but moderate construct validity (Sagvolden et al. 2005) and induces confounding results due to inattentiveness and hyperactivity. In our experiments we wanted to focus purely on motor impulsivity. Therefore, we induced hypodopaminergia via a 6-hydroxy dopamine (6-OHDA) lesion in the medial prefrontal cortex to target the cognitive circuits of the fronto-striatal circuitry. Since the levels of dopamine seem to follow a U-shaped dose-response curve, this model is suited to be used in future studies unraveling the pathophysiology of ADHD-related motor impulsivity an testing promising treatments (Arnsten 2009; Arnsten and Pliszka 2011). 


\section{References}

Alexander GE, DeLong MR, Strick PL (1986) Parallel organization of functionally segregated circuits linking basal ganglia and cortex. Annu Rev Neurosci 9 (1):357-381

Arnsten AF (2009) Toward a new understanding of attention-deficit hyperactivity disorder pathophysiology: an important role for prefrontal cortex dysfunction. CNS Drugs 23 Suppl 1:33-41. doi:10.2165/00023210-200923000-00005

Arnsten AF, Pliszka SR (2011) Catecholamine influences on prefrontal cortical function: relevance to treatment of attention deficit/hyperactivity disorder and related disorders. Pharmacol Biochem Behav 99 (2):211-216. doi:10.1016/j.pbb.2011.01.020

Beyeler A, Kadiri N, Navailles S, Boujema MB, Gonon F, Moine CL, Gross C, De Deurwaerdere P (2010) Stimulation of serotonin $2 \mathrm{C}$ receptors elicits abnormal oral movements by acting on pathways other than the sensorimotor one in the rat basal ganglia. Neuroscience 169 (1):158-170. doi:10.1016/j.neuroscience.2010.04.061

Chudasama Y, Robbins TW (2006) Functions of frontostriatal systems in cognition: comparative neuropsychopharmacological studies in rats, monkeys and humans. Biol Psychol 73 (1):19-38. doi:10.1016/j.biopsycho.2006.01.005

Gunaydin LA, Kreitzer AC (2015) Cortico-Basal Ganglia Circuit Function in Psychiatric Disease. Annu Rev Physiol. doi:10.1146/annurev-physiol-021115-105355

Haber SN, Rauch SL (2010) Neurocircuitry: a window into the networks underlying neuropsychiatric disease. Neuropsychopharmacology 35 (1):1-3. doi:10.1038/npp.2009.146

Maurice N, Deniau JM, Glowinski J, Thierry AM (1999) Relationships between the prefrontal cortex and the basal ganglia in the rat: physiology of the cortico-nigral circuits. J Neurosci 19 (11):4674-4681

Sagvolden T, Russell VA, Aase H, Johansen EB, Farshbaf M (2005) Rodent models of attentiondeficit/hyperactivity disorder. Biol Psychiatry 57 (11):1239-1247. doi:10.1016/j.biopsych.2005.02.002 
About the author 
Pim Heckman was born in Heerlen on November $24^{\text {th }} 1986$ and grew up in Kerkrade, the Netherlands. In 2006 he finished his high school education (Gymnasium) at College Rolduc in Kerkrade. In September 2006, he started studying Psychology at Maastricht University. In 2009 he obtained his Bachelor's Degree in 'Biological Psychology'. He continued his scientific career by obtaining his Master Degree in 'Neuropsychology' cum laude in 2011 at Maastricht University. Because he voluntarily extended the research period for his Master Thesis (to finish the study that was still ongoing when the internship period ended) he worked the remaining part of the academic year as a research assistant at the department of 'Neuropsychology and Psychopharmacology'. In September 2011 he started a Research Master in 'Cognitive and Clinical Neuroscience', for which he obtained his degree in 2013. For the Research Master he conducted research for his internship at the department of 'Psychiatry and Neuropsychology'. During his first master he worked in the group of Prof. J.G. Ramaekers, Dr. E. Theunissen and Dr. K. Kuypers on the effects of Vardenafil and Rivastigmine on THC-induced memory impairment. For his second (research) master he worked in the group of Dr. J. Prickaerts and Dr. A. Blokland on the effects of PDE2 and PDE4 inhibition on cognitive functioning related to cortico-striatal-thalamic circuitry. In 2013 Pim started working as a PhD student for Dr. J. Prickaerts and Dr. A. Blokland at the School for Mental Health and Neuroscience at Maastricht University. The latter resulted in the current thesis. 
List of publications 
Peer-reviewed publications:

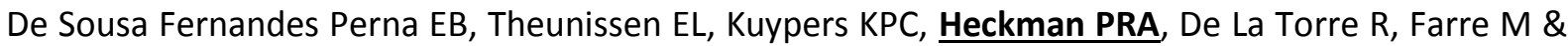
Ramaekers JG (2014) Memory and mood during MDMA intoxication, with and without memantine pretreatment. Neuropharmacology, 87, 198-205

Blokland A, Van Goethem N, Heckman PRA, Schreiber R, Prickaerts J (2014) Translational issues with the development of cognition enhancing drugs. Frontiers in Neurology, 5, 190

Theunissen EL, Heckman PRA, De Sousa Fernandes Perna EB, Kuypers KPC, Sambeth A, Blokland A, Prickaerts J, Toennes S \& Ramaekers JG (2015) Rivastigmine but not vardenafil reverses THC-induced impairment of verbal memory in healthy humans. Psychopharmacology, 232, 343-53

Heckman PRA, Wouters C \& Prickaerts J (2015) Phosphodiesterase inhibitors as a target for cognition enhancement in aging and Alzheimer's disease: a translational overview. Current Pharmaceutical Design, 21, 317-31

Heckman PRA, Blokland A, Ramaekers JG \& Prickaerts J (2015) PDE and cognitive processing: beyond the memory domain. Neurobiology of Learning and Memory, 119, 108-122

Heckman PRA, Van Duinen MA, Nishi A, Wennogle L, Blokland A \& Prickaerts J (2016) Phosphodiesterase inhibition and regulation of dopaminergic frontal and striatal functioning: clinical implications. International Journal of Neuropsychopharmacology,19, 1-16

Heckman PRA, Blokland A, Bollen EPP, Ramaekers JG \& Prickaerts J (2017) Phosphodiesterase inhibition and modulation of fronto-striatal and hippocampal circuits: clinical overview and translational considerations. Translational Neuroscience Reviews (in press)

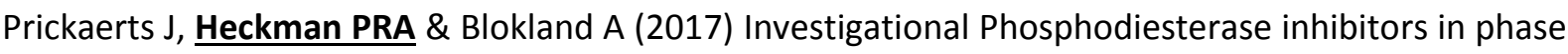
I and phase II clinical trials for Alzheimer's disease. Expert Opinion on Investigational Drugs (in press) 
Duinen MA, Sambeth A, Smit S, Heckman PRA, Tsai M, Lahu G, Uz T, Blokland A, Prickaerts J (2017) Single administration of roflumilast enhances Verbal Learning Test performance in humans with ageing-associated cognitive impairments. JAMA Neurology (under review)

Heckman PRA, Van Duinen MA, Blokland A, Uz T, Prickaerts J \& Sambeth A (2017) Single administration of roflumilast enhances sensory gating in healthy young humans. Translational Psychiatry (under review)

Heckman PRA, Schweimer JV, Sharp T, Prickaerts J \& Blokland A (2017) Effects of the phosphodiesterase type 4 inhibitor roflumilast on the tri-phasic response of the substantia nigra pars reticulata after infralimbic cortex stimulation. Brain Structure and Function (under review)

Heckman PRA, Blokland A \& Prickaerts J (2017) The mediating role of phosphodiesterase type 4 in the dopaminergic modulation of motor impulsivity. (in preparation)

\section{Peer-reviewed book chapters:}

Heckman PRA, Blokland A \& Prickaerts J (2016) From age-related cognitive decline to Alzheimer's disease: a translational overview of the potential role for phosphodiesterases. In H.T. Zhang (Ed.), Phosphodiesterases: CNS Functions and Diseases (pp. 88-135). London: Springer

Heckman PRA, Blokland A \& Prickaerts J (2017) Object Novelty Memory Tests and drug receptor studies. In A. Annaceur (Ed.), Handbook of Research on Object Novelty Recognition (pp. 34-67). London: Elsevier 
Acknowledgements 


\section{TO JOS AND ARJAN}

THE RABBIT, THE FOX, AND THE WOLF - A GRADUATE STUDENT FABLE

\section{Chapter One}

One sunny day, a rabbit came out of her hole in the ground to enjoy the weather. The day was so nice that the rabbit became careless, and a fox sneaked up behind her and caught her.

"I am going to eat you for lunch!" said the fox.

"Wait!" replied the rabbit. "You should at least wait a few days."

"Oh yeah? Why should I wait?" sneered the fox.

"I am almost finished writing my Ph.D. thesis," the rabbit said

"Hah! That's a stupid excuse. What is the title of your thesis anyway?"

"I am writing a thesis on `The Superiority Of Rabbits Over Foxes And Wolves."'

"Are you crazy? I should eat you right now!" the fox snarled. "Everybody knows that a fox will always win a fight with a rabbit."

"Not really, according to my research," said the rabbit. "If you'd like, you can come to my hole and read it for yourself. If you're not convinced, you can go ahead and have me for lunch."

"You really are crazy!" replied the fox. But the fox was pretty curious, and figured he had nothing to lose, so he went with the rabbit into its hole. The fox never came back out.

\section{Chapter Two}

A few days later the rabbit was again taking a break from writing. Sure enough, a wolf came out of the bushes, caught the rabbit, and was getting ready to eat her.

"Wait!" yelled the rabbit, "you cannot eat me right now."

"And why might that be, you fuzzy appetizer?"

"I am almost finished writing my Ph.D. thesis on "The Superiority Of Rabbits Over Foxes And Wolves."'

The wolf laughed so hard it almost lost its hold on the rabbit. "Maybe I shouldn't eat you-- you really are sick in the head and you might have something contagious!" the wolf opined.

"Come read for yourself. You can eat me after that if you disagree with my conclusions."

So the wolf went into the rabbit's hole... and like the fox, he never came back out.

\section{Chapter Three}

A few weeks later, the rabbit finished writing her thesis and was out celebrating in the lettuce fields. Another rabbit came by and asked, "What's up? You seem to be very happy."

"Yup, I just finished writing my dissertation." 


\section{"Congratulations! What is it about?" \\ "It is entitled 'The Superiority Of Rabbits Over Foxes And Wolves."' \\ "Are you sure? That doesn't sound right."}

"Oh, yes, you should come over and read for yourself."

So they went off together to the rabbit's hole.

As they entered, the friend saw what looked like a typical graduate student abode-- albeit a rather messy one after writing a thesis. The computer with the controversial dissertation was in one corner of the room. On the right there was a pile of fox bones, on the left was a pile of wolf bones, and in the middle was a lion.

And the moral of the story is:

Who you are doesn't matter. What the title of your dissertation is doesn't matter.

All that matters is who your thesis supervisor is. 
Het enige wat nu nog rest is het dankwoord, het meest gelezen onderdeel van het proefschrift! Hierin wil ik alle mensen bedanken die hebben bijgedragen aan het tot stand komen van dit proefschrift. De tijd ging snel, maar wat hebben we genoten!

Ten eerste wil ik natuurlijk mijn promotor bedanken, Prof. Jan Ramaekers! Beste Jan, al vanaf de bachelor ben jij één van de redenen waarom ik zo van de combinatie 'psychofarmacologie and neuroscience' houd! Je hebt mij altijd bijgestaan met advies en inspiratie!

Dan natuurlijk mijn co-promotores! Van jong naar nog jonger: Arjan Blokland en Jos Prickaerts. Beste Jos en Arjan, ik weet eerlijk gezegd niet eens waar ik moet beginnen. Jij en Arjan zijn mijn absolute mentoren! Jullie zijn zo belangrijk voor mij dat ik een speciaal hoofdstuk aan jullie heb gewijd. Jullie hadden werkelijk altijd tijd voor mij, hebben mij voorzien van inspiratie en motivatie, en hebben mij alles geleerd wat mij maakt tot de wetenschapper die ik nu ben. Dankzij jullie heb ik een aantal belangrijke levenslessen geleerd die goed van pas gaan komen tijdens de rest van mijn carrière op weg naar de top! Jullie hebben nu al zo veel voor mij gedaan, dat ik dit de rest van mijn leven niet terug kan geven.

Many thanks also go to the members of my reading committee, Prof. Wim Riedel (voorzitter, Maastricht University), Prof. Rudi D’Hooge (Katholieke Universiteit Leuven), Prof. Harald Schmidt (Maastricht University), Dr. Tim Vanmierlo (Universiteit Hasselt) and Dr. Anthony West (Rosalind Franklin University of Medicine and Science, Chicago) for accepting to read and assess my PhD dissertation. I would also like to thank the additional members of my corona.

Special thanks gaan uiteraard ook uit naar alle (ex)leden van de MC groep. Bedankt voor alle hulp voor, tijdens en na de vele experimenten, maar ook voor alle plezier en onvergetelijke momenten over de jaren! Het waren echt geweldige momenten tijdens alle MC meetings, lab-day outs, congressen, workshops, cursussen, PhD meetings, pizzameetings, borrels en iedere andere reden voor gezelligheid (lees: drank). Special thanks to: Marlies van Duinen, Kris Rutten, Tim Vanmierlo, Olga Reneerkens, Jochen De Vry, Eva Bollen (bedankt voor alle geweldige figuren die je voor mij gemaakt hebt), Nick van Goethem, Caroline Wouters, Britt van Hagen, Elentina Argyrousi, Dean Peas, Sander Smit, Stephanie Caldenhove en Sven Akkerman.

Of course I would also like to thank all the Sharpies, who were so kind to welcome me into their group. First of all I like to thank Prof. Trevor Sharp for supporting me and believing in my ideas. Also, I like to thank Judith and Julia for teaching me all I know about ephys recordings. Of course none of the recordings would have mattered without the PBS skills thought to me by Sanziana (:) 
Additionally, I like to thank Prof. Peter Magill, Grant, Chris, Raquel and Alex! I really hope to see you all again soon!

Also, I would like to thank all my colleagues from MHeNS division 3! All the seniors and especially the PhDs: Wiel, Ali, Mark, Sandra, Govert, Majed, Fred, Anne, Gusta, Milaine, Sarah, Paul, Judith, Beth, Melanie, Celine, Maartje, Bart, Daniel, Gunter, Laurence, Eshan, Mark, Nicole, Roy, Artemis, An, Magda, Nynke, Koen, Maarten, Glenn, Roel, Marc, Pilar, Mario, Jo, Yara, Carolin, Simone, Marina, Shengua, Shannen, Wouter, Christian, Melinda, Anna, Manon, Ramona, Aryo and Rachelle

Likewise, I wish to thank all my colleagues from NP/PP: Annemie, Anita, Nick, Stefan, Robbie, Joep, Natasha, Ben, Des, Rachel, Michel, Jens, Frederick, Jessica, leke, Anne, Aimee, Silke, Zoe, Christine, Eliza, Melloney, Eva, Inge, Laura, Franziska, Anke, Peter, Eric, Petra, Rob, Martin, Lisbeth, Pascal, Eri, Caroline, Sonja, Esther, Irene, Connie, Wijnand and Annemiek

Beste Eef en Kim, voor jullie een eigen paragraaf. Bij jullie is alles begonnen! Ontzettend bedankt voor de kans die jullie mij gegeven hebben om mijn stage in jullie groep te doen en mijzelf te ontwikkelen als onderzoeker. Onze samenwerking verliep zo goed dat ik zelfs mocht blijven als student-assistent totdat ik aan mijn $\left(2^{\mathrm{e}}\right)$ research master ging beginnen. Ook al werk ik nu voornamelijk bij FHML, ik zal niet vergeten wat jullie voor mij gedaan hebben! Hopelijk kunnen we in de toekomst nog vaker samenwerken!

Ook wil ik graag alle technicians bedanken voor alle hulp! Zonder jullie was dit mooie boekje niet mogelijk geweest. Bedankt Hellen, Denise, Marjan en Marcella!

Net zo belangrijk zijn alle mensen van CPV. Richard, Saskia, Inger, Harry, Rik, Paul, Mandy en Clarice!

Special thanks also go out to all my Brazilian friends! Melina, Davi, Ligia, Vivian, Leandro and Rubia. Muito obrigado!

Natuurlijk wil ik ook alle collega's van de Albert Heijn bedanken voor hun steun en maandelijkse uitjes en etentjes. Fijn dat, zelfs nu wij niet meer bij elkaar werken, wij toch nog steeds veel samen ondernemen! Bedankt Rob, Ellen, Torsten, Gina, Arez, Zainab, Tamara, en Trudy

Daarnaast wil ik al mijn vrienden uit Kerkrade en omstreken bedanken voor de ontelbaar goede tijden die we samen hebben gehad en die tegenwicht boden aan al het harde werken en de lange dagen in Maastricht. Ten eerste natuurlijk Paul Meijer a.k.a. "de President" die erbij was vanaf het 
eerste uur! Net als Matej Majstorovic en Zeljko Zubak. Mijn twee vrienden uit Kroatië/Terwinselen. Zonder jullie was dit nooit gelukt! Ook Frank Meijer wil ik nog speciaal bedanken voor alles wat je voor mij gedaan en betekend hebt over de jaren. Verder natuurlijk ook de rest van de crew: Tom, Danny, Nicky, Jens, Jelle, Toni, Mark, Mark, Sjang, Pim, Jos en alle anderen die ik hier niet allemaal kan opnoemen! Koempels Kerkrade!

Lieve Pap, Mam en Luuk en familie. Jullie zijn het belangrijkste van iedereen! Alleen door jullie steun, vertrouwen, hulp en kracht heb ik mijn promotie-traject inclusief proefschrift succesvol kunnen afronden! Jullie zijn altijd een bron van inspiratie en motivatie voor mij geweest! Zonder jullie ben ik nergens! 